\title{
PROJETO DE REDES DE DISTRIBUIÇÃO FÍSICA CONSIDERANDO A INFLUÊNCIA DO IMPOSTO DE CIRCULAÇÃO DE MERCADORIAS E SERVIÇOS
}

Tese apresentada à Escola

Politécnica da Universidade de

São Paulo para obtenção do

Título de Professor Livre Docente, junto ao Departamento de

Engenharia de Produção 
HUGO TSUGUNOBU YOSHIDA YOSHIZAKI

\section{PROJETO DE REDES DE DISTRIBUIÇÃO FÍSICA CONSIDERANDO A INFLUÊNCIA DO IMPOSTO DE CIRCULAÇÃO DE MERCADORIAS E SERVIÇOS}

Tese apresentada à Escola

Politécnica da Universidade de

São Paulo para obtenção do

Título de Professor Livre Docente 
YOSHIZAKI, Hugo T. Y.

Projeto de redes de distribuição física considerando a influência do imposto de circulação de mercadorias e serviços. São Paulo: EPUSP/Departamento de Engenharia de Produção, 2002.

144 p. il.

Tese (Livre Docência) - Escola Politécnica da Universidade de São Paulo. Departamento de Engenharia de Produção.

1. Redes de distribuição. 2. Imposto de circulação de mercadorias e serviços. 3. Logística. 4. Supply chain management. 5. Localização industrial. 6. Otimização. I. Universidade de São Paulo. Escola Politécnica. Departamento de Engenharia de Produção. II. t. 
Ao meu filho Renato e a minha mulher Jane, que todo dia me ensinam o significado da palavra Amor. 


\section{AGRADECIMENTOS}

Ao amigo Celso Mitsuo Hino, sem cuja dedicação e esforço, afora os profundos conhecimentos de GAMS, esta tese não teria sido praticável.

Ao colega Prof. Dr. Jorge Luiz de Biazzi e aos alunos Salomão Siu e Guilherme Guidolin de Campos, colaboradores incansáveis.

À senhora Simone Nascimento Silva, da ACNielsen, e aos senhores Eduardo Mariath, ex-diretor da Cesamar Logística, Edson Tokuzumi, da TAM, Eduardo Oliveira, da Unilever/Best Foods, Evandro Luis Moraes, da Bunge Alimentos, Francisco Tabajara de Brito, da Danzas, Gilmar Winck, do Carrefour, Nelson Machado, da FAZESP, Ozoni Argenton, da Martin Brower, Ricardo Monteiro, da Procter \& Gamble, Rogério Aversa, da Escola Politécnica, e Roberto Vilarinho, da Unilever, pelas valiosas informações e comentários.

A todos os outros que colaboraram neste trabalho.

Esta pesquisa foi financiada pela FAPESP sob o contrato 01/05376-1 


\section{RESUMO}

Este trabalho estuda a influência da atual estrutura de alíquotas internas e interestaduais do Imposto sobre Circulação de Mercadorias e Serviços sobre o projeto de localização de centros de distribuição para indústrias de bens de consumo não duráveis, do tipo encontrado no comércio de auto-serviço. Foi montado um problema padrão, onde quatro indústrias têm sua distribuição conjunta coordenada por um único operador logístico para obtenção de economias de escala. A solução para o problema foi obtida através de um modelo de Programação Linear Inteira Mista, cujos parâmetros de demandas e custos foram estimados utilizando-se valores reais do mercado (base segundo semestre de 2000). Conclui-se que a atual estrutura desse tributo afeta grandemente os custos logísticos e a decisão de localizar instalações logísticas. Portanto, é fundamental integrar o planejamento tributário à disciplina logística, sob pena de se desenvolver sistemas de distribuição subotimizados. 


\begin{abstract}
This research evaluates the influence of the current state sale taxes for internal and interstate operations over distribution center location decisions of consumer packaged goods industries. A standard problem case contains four nation-wide manufacturers, which distribute their products together by means of a particular third party logistics integrator operating their joint distribution to obtain economies of scale. A Mixed Integer Linear Programming model is employed to optimize the problem. Cost and demand parameters has been calculated with real world values (data from second semester, 2000). The results show that the current state tax structure significantly affect logistics costs, and, therefore, where to place distribution depots. Thus, it is crucial to integrate tax planning into the logistics discipline, as to avoid severe distribution system sub-optimization.
\end{abstract}




\section{SUMÁRIO}

\section{LISTA DE FIGURAS}

LISTA DE TABELAS

1. INTRODUÇÃ

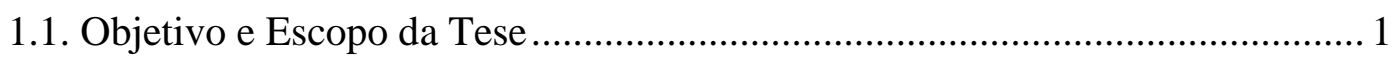

1.2. Relevância do tema ..................................................................................... 2

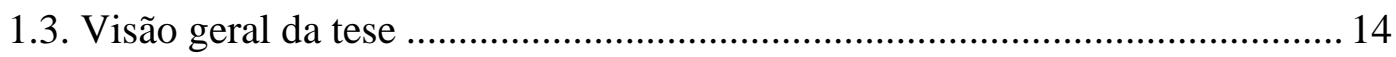

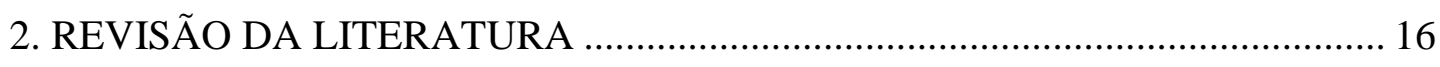

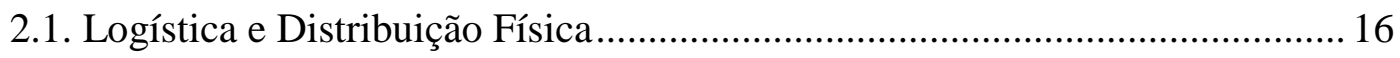

2.2. Gerenciamento da Cadeia de Suprimentos (Supply Chain Management) ...... 21

2.3. Enfoque Sistêmico aplicado à Logística ....................................................... 23

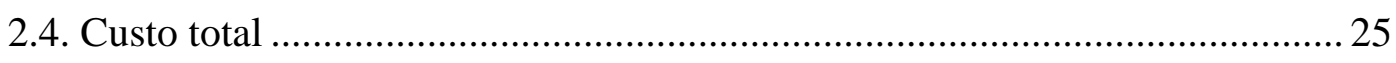

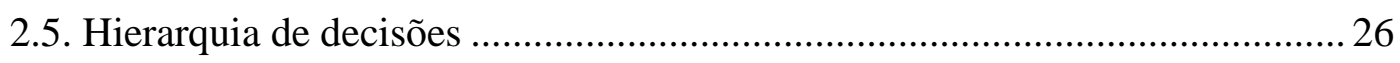

2.6. Projeto de cadeias de distribuição (modelos de localização) .......................... 30

2.7. A questão tributária e o ICMS .................................................................... 38

2.8. Trabalhos prévios de Logística e ICMS ....................................................... 48

3. METODOLOGIA E MODELAGEM DO PROBLEMA .................................... 51

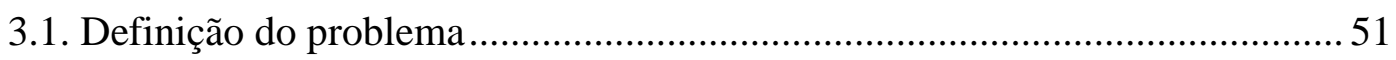

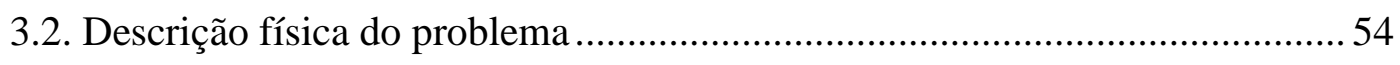

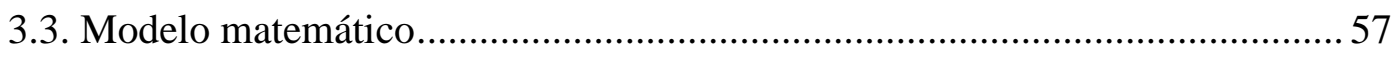

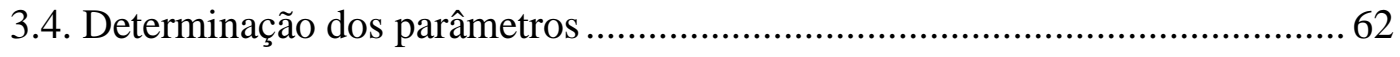

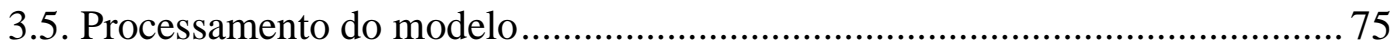

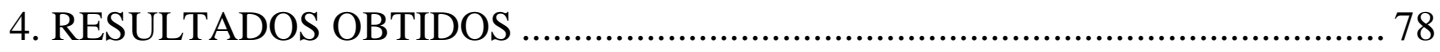

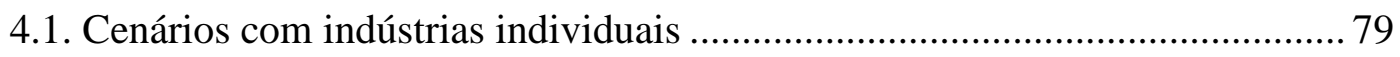

4.2. Resultados do Cenário Básico Multiprodutos ............................................... 90

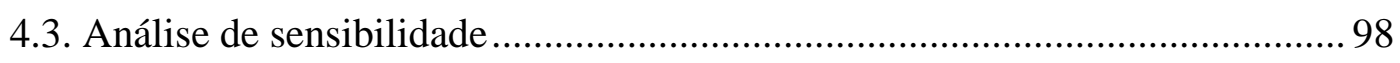

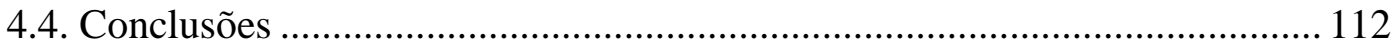

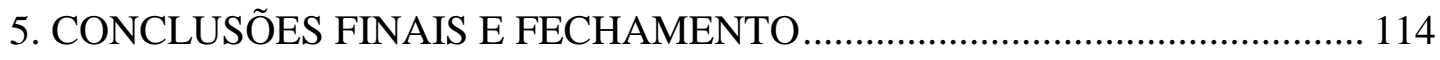

5.1. Conclusões sobre a estrutura de alíquotas do ICMS e a Logística ................ 114

5.2. Críticas e comentários sobre a modelagem empregada ............................. 122

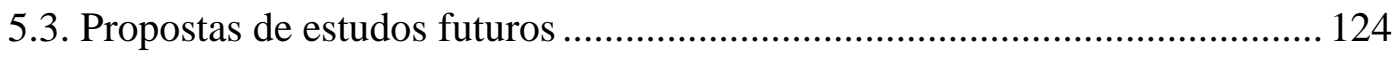


5.4. Comentários finais 128

ANEXO A - MESORREGIÕES PARA MERCADOS ........................................ 129

ANEXO B - TABELA DE ALÍQUOTAS DE ICMS ........................................... 132

ANEXO C - TABELAS DE CUSTO PARA DISTRIBUIÇÃO INDIVIDUAL .... 134

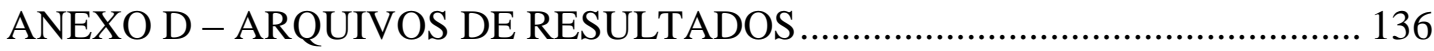

ANEXO E - TABELA DE MUNICÍPIOS, MICRO E MESORREGIÕES IBGE . 138

LISTA DE REFERÊNCIAS 139 


\section{LISTA DE FIGURAS}

Figura 2.1. Atividades da Logística (adaptado de Ballou, 1999).

Figura 2.2. Exemplo de estrutura de canal para bens de consumo não-duráveis (adaptado de Bowersox e Closs, 1996, Cap. 4) ............................................... 18

Figura 2.3. Exemplo de hierarquia de decisões em Logística.................................. 28

Figura 2.4. Exemplo de rede de distribuição.......................................................... 31

Figura 3.1. Municípios com possibilidade de abertura de CD's...............................55

Figura 3.2. Demanda (em toneladas) dos produtos com origem na fábrica SP.........68

Figura 3.3. Demanda (em toneladas) dos produtos com origem na fábrica SC......... 68

Figura 3.4. Demanda (em toneladas) dos produtos com origem na fábrica GO........ 69

Figura 3.5. Demanda (em toneladas) dos produtos com origem na fábrica PE ......... 69

Figura 3.6. Demanda com origem na fábrica SP com relevo tridimensional. ........... 70

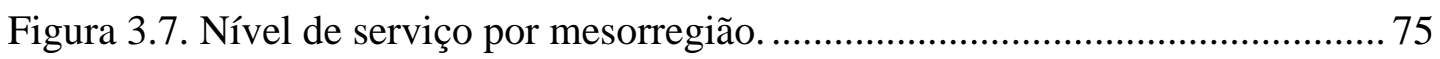

Figura 3.8. Mesorregiões com nível de serviço original (comparar com figura

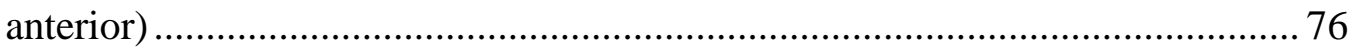

Figura 4.1. Áreas de influência de fábrica e CD’s, origem GO, sonegação assumida $0 \%$. 80

Figura 4.2. Áreas de influência de fábrica e CD’s, origem GO, sonegação assumida $100 \%$

Figura 4.3. Áreas de influência de fábrica e CD’s, origem SP, sonegação assumida $0 \%$. 85

Figura 4.4. Áreas de influência de fábrica e CD’s, origem SP, sonegação assumida $100 \%$. .85

Figura 4.5. Áreas de influência de fábrica e CD’s, origem SC, sonegação assumida $0 \%$. 86

Figura 4.6. Áreas de influência de fábrica e CD’s, origem SC, sonegação assumida $100 \%$. 86

Figura 4.7. Áreas de influência de fábrica e CD’s, origem PE, sonegação assumida $0 \%$. .87

Figura 4.8. Áreas de influência de fábrica e CD’s, origem PE, sonegação assumida $100 \%$. 
Figura 4.9. Comparação entre cenários com $0 \%$ e $100 \%$ de sonegação assumida, problema base.

Figura 4.10. Áreas de influência, produto origem SP, 0\% sonegação assumida....... 94

Figura 4.11. Áreas de influência, produto origem SP, 100\% sonegação assumida ... 94

Figura 4.12. Áreas de influência, produto origem SC, 0\% sonegação assumida....... 95

Figura 4.13. Áreas de influência, produto origem SC, 100\% sonegação assumida... 95

Figura 4.14. Áreas de influência, produto origem GO, 0\% sonegação assumida...... 96

Figura 4.15. Áreas de influência, produto origem GO, 100\% sonegação assumida.. 96

Figura 4.16. Áreas de influência, produto origem PE, 0\% sonegação assumida....... 97

Figura 4.17. Áreas de influência, produto origem PE, 100\% sonegação assumida... 97

Figura 4.18. Crescimento de custos em função do índice de sonegação (cenário base)

Figura 4.19. Curvas de custos logísticos e ICMS no problema base, variando-se o índice de sonegação. 100

Figura 4.20. Componentes de custo logístico para cenário-base. 100

Figura 4.21. Áreas de influência, produto origem SP, $20 \%$ sonegação assumida, clientes querem crédito de ICMS $(\mathrm{s}=2)$. 104

Figura 4.22. Áreas de influência, produto origem SP, $20 \%$ sonegação assumida, cliente indiferentes ao crédito de ICMS (sonegadores potenciais, s =1) . ........ 104

Figura 4.23. Custos componentes para cenário com preço de R\$ 625,00/t ............. 109

Figura 4.24. Custos componentes para cenário com preço de $\mathrm{R} \$ 1.250,00 / \mathrm{t}$........... 109

Figura 4.25. Custos componentes para cenário com preço de $\mathrm{R} \$ 5.000,00 /$ t. ......... 110

Figura 4.26. Curva de tradeoff entre custo logístico e ICMS, preço médio R\$ 625/t.

Figura 4.27. Superfície de custo logístico em função de sonegação e preço.

Figura 5.1. Aumento relativo do custo logístico, cenário com preço R \$ 2.500/t .... 115

Figura 5.2. Crescimento relativo do custo logístico em função do preço e da sonegação

Figura 5.3. Variação do débito relativo do ICMS (\% preço médio) conforme preço médio e índice de sonegação, para o agregado das indústrias (distribuição conjunta).

Figura D.1. Mapas de código dos cenários 137 


\section{LISTA DE TABELAS}

Tabela 1.1. Extrato do arquivo de descontos logísticos usado.

Tabela 2.1. Segmentação típica de canal para fabricantes de bens de consumo nãoduráveis, em volume de produto.

Tabela 2.2. Hierarquia de decisão para o problema da inter-relação Logística-ICMS

Tabela 3.1. Locais candidatos a Centros de Distribuição ........................................... 56

Tabela 3.2. Tabela com consumo per/capita (Fonte AC Nielsen, 2001) .................... 64

Tabela 3.3. Conversão demanda tonelada líquida para bruta..................................... 66

Tabela 3.4. Demanda anuais totais para cada produto (peso bruto total) .................. 67

Tabela 3.5. Níveis de capacidade nos depósitos ou CD's........................................ 71

Tabela 3.6. Restrição de nível de serviço................................................................ 74

Tabela 3.7. População das principais mesorregiões................................................. 74

Tabela 4.1.Comparação de custos das diversas origens............................................. 79

Tabela 4.2. Áreas de influência dos CD’s para origem GO, sonegação assumida $0 \%$.

Tabela 4.3. Quadro resumo de depósitos e fluxo via CD's 88

Tabela 4.4. Ganhos de Escala referentes à Distribuição Conjunta - sem sonegação. 90

Tabela 4.5. Ganhos de escala referentes à Distribuição Conjunta - 100\% sonegação assumida

Tabela 4.6. Volume movimentado nos cenários puros (distribuição independente e conjunta)

Tabela 4.7. Comparação dos cenários $0 \%$ e $100 \%$ de sonegação assumida para problema base (preço $\mathrm{R} \$ 2.500 / \mathrm{t}$ ).

Tabela 4.8. Custos para cenário-base (preço médio $\mathrm{R} \$ 2.500 / \mathrm{t}$ ) - valores em $\mathrm{R} \$$ milhões .98

Tabela 4.9. Mapa de abertura-fechamento de $\mathrm{CD}^{\prime}$ s no cenário-base (preço $\mathrm{R} \$$ $2.500 / \mathrm{t})$ 102

Tabela 4.10. Tabela-resumo do cenário come preço médio de $\mathrm{R} \$ 625,00 / \mathrm{t}$. 106

Tabela 4.11. Tabela-resumo do cenário com preço médio de R \$ 1.250/t................ 107

Tabela 4.12. Tabela resumo do cenário com preço médio de $\mathrm{R} \$ 5.000,00 /$ t........... 108 
Tabela 5.1. Aumento relativo no custo logístico (cenário base preço R \$ 2.500/t) .. 115

Tabela 5.2. Incremento relativo do custo logístico com relação ao cenário $0 \%$ de sonegação

Tabela 5.3. Recolhimento médio de ICMS por cenário (débito/faturamento, em \%) 118

Tabela B.1. Porcentuais de incidência de ICMS sobre o produto entre Estados ..... 133

Tabela C.1. Custos dos Cenário Puros: Distribuição Independente Origem São Paulo 134

Tabela C.2. Custos dos Cenário Puros: Distribuição Independente Origem Joinville 134

Tabela C.3. Custos dos Cenário Puros: Distribuição Independente Origem Goiânia 135

Tabela C.4. Custos dos Cenários Puros: Distribuição Independente Origem Recife 135 


\section{INTRODUÇÃO}

\subsection{Objetivo e Escopo da Tese}

É lugar comum no Brasil dizer-se que a estrutura de impostos estaduais (no caso, o ICMS - Imposto sobre Circulação de Mercadorias e Serviços) tem grande efeito na logística, pois decisões de instalar fábricas e armazéns buscam minimizar efeitos da tributação em detrimento de custos de transporte e distribuição. Assim, esta pesquisa tem por objetivos:

- Estudar os tradeoffs entre custos logísticos e o Imposto de Circulação de Mercadorias e Serviços (ICMS);

- Avaliar a influência potencial do ICMS no projeto de sistemas de distribuição física;

- Discutir o impacto geral da estrutura do ICMS na logística de empresas brasileiras.

Esta tese se restringe a tratar os tradeoffs entre Logística e o ICMS, não contemplando outros impostos indiretos (como o Imposto sobre Produtos Industrializados - IPI) e incentivos. Para isto, vai focalizar somente a distribuição física de bens de consumo não duráveis, do tipo encontrado no varejo supermercadista (auto serviço), não avaliando o impacto do ICMS na parte de insumos industriais e transformação (manufatura). Assim, não se pretende explorar todo o encadeamento do ICMS na cadeia de suprimentos, mas apenas na parte final da mesma. Além disso, desconsiderou-se o ICMS que incide sobre os fretes, pois seu impacto é pequeno comparado aos outros itens do custo total.

Pelo seu intuito de analisar a inter-relação entre o ICMS e Logística, o escopo da tese evidentemente engloba unicamente o caso da Logística brasileira. 


\subsection{Relevância do tema}

É inegável a grande importância do ICMS para a sociedade brasileira. No ano 2000, o montante total de ICMS arrecadado em todos os Estados foi de 82,28 bilhões de reais (Conselho Nacional de Política Fazendária - CONFAZ, 2001). De acordo com a Secretaria da Receita Federal (2001), isto corresponde a 87\% da carga tributária dos Estados e 22,8\% da carga tributária total brasileira ( $\mathrm{R} \$ 361,57$ bilhões, ou $33,18 \%$ do Produto Interno Bruto - PIB - brasileiro). Logo, o ICMS recolhe o equivalente a 7,55\% do nosso PIB (que foi de R $\$ 1.089,68$ bilhões).

Por outro lado, não há dados precisos da participação das atividades logísticas no PIB brasileiro (Novaes, 2001, pg. 51). Como apenas a atividade de transporte absorve cerca de10\% de nosso PIB (Fleury, 2000, pg. 21), Novaes (2001) cita que alguns autores consideram que a participação total da logística pode chegar à casa $\operatorname{dos} 20 \%$.

Há dados confiáveis para os Estados Unidos da América: citando o Bureau of Economic Analysis norte-americano, Novaes (2001) coloca uma participação de 9,9\% na economia americana em 1999; essa fração vem caindo de um patamar de $16 \%$ em 1981. Face a esta informação, o número de 17\% do PIB para o caso brasileiro, usado por alguns consultores, parece mais plausível.

De qualquer maneira, as atividades logísticas representam parcela importante da nossa economia.

E qual é o entrelaçamento entre o ICMS e a Logística? Por que é importante estudar ambos em conjunto? Para dar uma resposta, é importante conhecer em detalhe o mecanismo ou estrutura do ICMS e como isto acaba gerando um "turismo" (tráfego artificialmente criado) de produtos em nossas vias e estradas. 


\subsubsection{A estrutura interestadual do ICMS e o potencial para turismo de produtos}

O ICMS é um tributo estadual que incide sobre o valor faturado (preço) dos produtos de empresas ao longo de uma cadeia produtiva ou comercial. Cada Estado da União tem uma alíquota definida para cada tipo de produto e operação comercial (compra e venda). A alíquota padrão para operações internas, conforme pode ser visto na diagonal principal da Tabela B.1 (Anexo B), varia entre 18\% na maioria dos Estados do Sul-Sudeste e $17 \%$ nos outros (Conselho Nacional de Política Fazendária CONFAZ, 2001).

O que chama a atenção na tabela citada, porém, são as alíquotas para o comércio interestadual: para operações entre Estados (fornecedor em um Estado e cliente em outro), o porcentual que incide sobre o preço da transação é de $12 \%$ (as exceções são as operações Sul-Sudeste para o resto do país, onde a alíquota é de 7\%), ou seja, favorece-se a exportação de produtos pelos Estados. A tabela expressa o acordo vigente entre as diversas Secretarias Estaduais da Fazenda que compõem o CONFAZ e tem natureza duradoura. Por isso, neste estudo não estão incluídos os incentivos fiscais (redução de base de cálculo) do ICMS, pois eles são de natureza transitória, sendo determinados por decretos dos Poderes Executivos do Estados e, portanto, passíveis de alteração a qualquer momento.

Para verificar qual é o impacto da estrutura do ICMS, é mister entender como funciona o cálculo do tributo. Isto será realizado por intermédio de um exemplo.

Tome-se o caso de uma indústria de bens de consumo não-duráveis que comercializa um produto pelo preço de venda de $\mathrm{R} \$ 2500,00$ por tonelada (valor típico para o ano 2000-2001), localizada no Estado de São Paulo. O cliente (estabelecimento varejista) fica no Estado de Sergipe. Vai-se utilizar o ponto de vista dessa empresa, ou seja, apenas a parcela da cadeia produtiva sob seu controle será avaliada. Para facilitar a compreensão, vamos assumir que não há agregação de valor nessa cadeia (ou seja, o preço se mantém inalterado em $\mathrm{R} \$ 2.500 / \mathrm{t})$. 
Além disso, dadas as distâncias envolvidas, a indústria mantém um depósito no Nordeste para atender prontamente os clientes sergipanos. Idealizou-se dois casos: no primeiro temos o depósito situado no mesmo Estado (Sergipe); no segundo, o depósito fica localizado na Bahia (a distância Salvador-Aracaju é de aproximadamente $320 \mathrm{~km}$ ). Eles estão esquematizados no Quadro 1.1: antes da linha vertical pontilhada, há a indústria (representada pela fábrica e pelo depósito); à direita, tem-se o cliente dessa indústria (varejista) e o consumidor final. Para cada caso, colocou-se na parte superior o fluxo de mercadorias, representado por figuras (fábrica, depósito, varejista e consumidor final); logo abaixo, vê-se o fluxo de impostos, com linhas para os créditos e débitos em cada estágio do fluxo, mais as linhas com o saldo de cada estágio e os totais para a indústria (até a linha pontilhada vertical) e geral (totalizando todos os saldos, ou seja, o imposto total recolhido na cadeia de valor).

Da tabela B.1 (Anexo B), observa-se que as alíquotas do ICMS do Quadro 1.1 são: para exportações SP-Nordeste (inclui Bahia e Sergipe), tem-se 7\%; para operações comerciais internas em Sergipe, 17\%; para exportações Nordeste-Nordeste (no caso, Bahia-Sergipe), a alíquota é de $12 \%$.

Como foi dito, o ICMS é aplicado sem acúmulo ao longo da cadeia de valor. Assim, para fabricar seu produto que é vendido a $\mathrm{R} \$ 2500,00$, a indústria comprou matériasprimas em um valor qualquer provenientes do mesmo Estado; nesse valor de compra de materiais está embutido o ICMS de 17\%. Pelo princípio da não-cumulatividade (ou seja, cada estágio da cadeia comercial recolhe apenas o imposto calculado por sua agregação de valor, vide item 2.7.1, Capítulo 2), esse valor de ICMS embutido fica como um crédito para a indústria, que é utilizado contra o débito de ICMS quando a mesma empresa vender seu produto. Como o crédito é constante, ele não influencia as decisões de distribuição da indústria nesse exemplo e torna-se irrelevante para a análise. Assim, sem perda de generalidade e para facilitar o raciocínio, adotou-se a hipótese de valor zero para a matéria-prima, como se a cadeia de distribuição começasse aqui (o crédito inicial fica zero). 


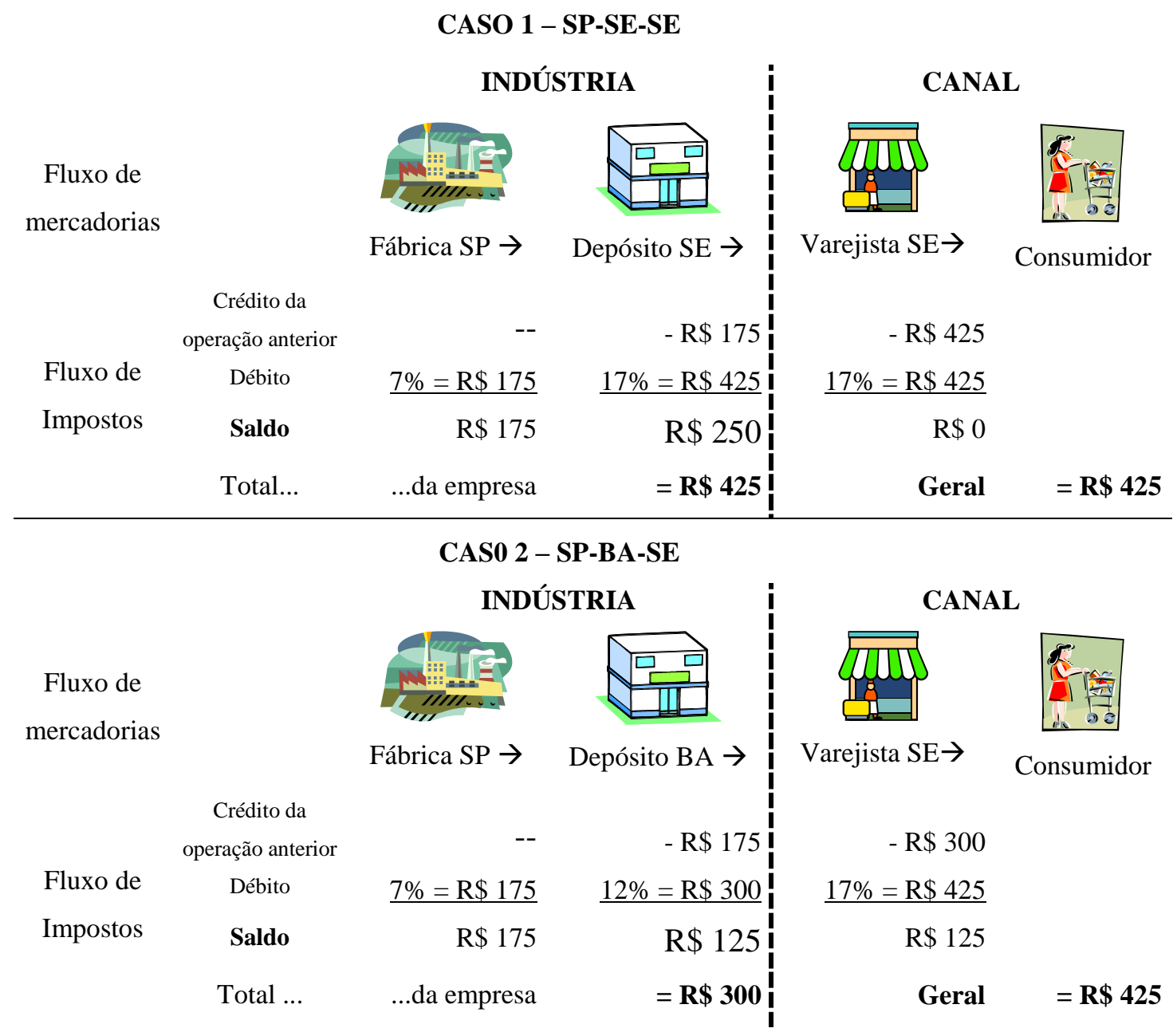

Quadro 1.1. Exemplo de Cadeia do ICMS: preço constante de R $\mathbf{2 . 5 0 0 , 0 0 / t}$

Verifique-se o caso 1, no qual o depósito ou centro de distribuição fica no Estado de Sergipe. A fábrica, através de uma nota fiscal de transferência, passa a propriedade para o depósito de Sergipe, tendo então um débito de ICMS de 7\% da transação, ou seja, 7\% de $\mathrm{R} \$ 2.500,00=\mathrm{R} \$ 175,00$. O depósito recebe a mercadoria e se credita desses $7 \%$, ou seja, $\mathrm{R} \$ 175,00$. Como o depósito vende essa mercadoria para um cliente no mesmo Estado, ele vai ter um débito de $17 \%$ de $\mathrm{R} \$ 2.500,00=\mathrm{R} \$ 425,00$. Assim, o saldo a pagar de ICMS pelo sistema indústria (fábrica mais depósito) é de $\mathrm{R} \$ 175,00-\mathrm{R} \$ 175,00+\mathrm{R} \$ 425,00=\mathrm{R} \$ 425,00$ (última linha). Novamente pelo princípio da não-cumulatividade (vide capítulo 2), o varejista tem um crédito de $\mathrm{R} \$$ 425,00; quando ele vender a mercadoria, terá um débito de $\mathrm{R} \$ 425,00$, gerando um saldo final de zero. A mercadoria, comprada pelo consumidor final pelo valor de $\mathrm{R} \$$ 
2.500,00, tem o ICMS completamente dentro do preço (Total geral $=\mathrm{R} \$ 425,00$ ). Assim, o consumidor está, no final da cadeia, pagando o ICMS total.

Veja-se agora o caso 2, onde o depósito do fabricante está localizado na Bahia e a venda ao cliente de Sergipe tem o débito de $12 \%$ de $\mathrm{R} \$ 2.500,00=\mathrm{R} \$ 300,00$. Então, o saldo de ICMS a pagar do sistema indústria é de $\mathrm{R} \$ 175,00-\mathrm{R} \$ 175,00+\mathrm{R} \$$ $300,00=\mathrm{R} \$ 300,00$. Contudo, como o varejista terá a alíquota de $17 \%$ na venda, o seu saldo agora é de $-\mathrm{R} \$ 300,00+\mathrm{R} \$ 425,00=\mathrm{R} \$ 125,00$. Para o consumidor final nada muda, pois o ICMS total continua sendo o total geral de (saldo da indústria + saldo do varejista $)=R \$ 300,00+R \$ 125,00=R \$ 425,00$. A receita total de impostos para o governo (Estados) continua a mesma, ou seja, ambos os casos são equivalentes.

Para a indústria (vide colunas à esquerda da linha pontilhada no Quadro 1.1), entretanto, não há equivalência: no caso 1, ela precisa desembolsar (pagar) $\mathrm{R} \$$ 425,00 de ICMS no total; no caso 2, apenas R \$ 300,00, uma economia aparente de $\mathrm{R} \$ 125,00$, que corresponde aos 5\% de diferença nas alíquotas inter e intra-estaduais (12\% versus $17 \%$ ). Assim, parece muito mais vantajoso abastecer o cliente sergipano a partir de uma instalação em outro Estado.

A questão do turismo de produtos para se beneficiar da atual estrutura do ICMS fica então mais clara: para o fornecedor (fabricante, distribuidor ou atacadista), passa a ser mais interessante entregar de um Estado vizinho ao cliente do que a partir do mesmo. E por que isto afeta a Logística? Se o fornecedor tiver opção, ele pode entregar a mercadoria a partir de uma instalação fora do Estado. Basta verificar a ordem de grandeza dos números: $5 \%$ de diferença nas alíquotas significam $\mathrm{R} \$$ $125,00 / t$; esse valor é mais que suficiente para pagar um frete de $1.500 \mathrm{~km}$, que é mais ou menos a distância Rio-Salvador.

Isto naturalmente acaba gerando distorções. Por exemplo, o folclore logístico registra o turismo de produtos fabricados no Estado de São Paulo, transferidos para filiais em Minas Gerais (via de regra, para depósitos na divisa de Estados) e então vendidos 
para clientes de São Paulo. A contrapartida do incremento dos custos de operação logística (transporte e armazenagem) é uma economia de ICMS de 6\% do valor do produto (diferença de alíquotas). Assim, passa a ser economicamente vantajoso instalar um depósito no outro Estado.

Isto parece explicar o fato de alguns atacadistas e distribuidores de bebidas preferirem se instalar no Sul de Minas Gerais, próximos a grandes centros de consumo como Grande São Paulo e Grande Rio. O atual ICMS teria potencializado assim grandes distorções na rede logística nacional, pois se encarece custos logísticos para obter vantagens fiscais, gerando uma classe do "custo Brasil".

\subsubsection{O tradeoff entre Logística e sonegação do ICMS}

O principal problema da análise feita ao final do subitem anterior é sua parcialidade: ao considerar o sistema formado apenas pela indústria, parece haver grande potencial de ganho ao se observar a influência do ICMS no custo total. Porém, deve-se recordar que o ICMS é um imposto que incide sobre toda a cadeia; por isso, precisase notar o que ocorre com o cliente (no caso analisado, o varejista). A falácia ocorre ao se "quebrar" a cadeia do imposto na linha pontilhada do Quadro 1.1.

Revendo o mesmo, repara-se que o cliente (à direita da linha pontilhada) tem saldos diferentes de ICMS a pagar: no caso 1, seu saldo é zero; no caso 2, seu saldo é R\$ 125,00. Será que ele aceitará essa transferência passivamente? Pode o varejista ser indiferente?Afinal de contas, se o preço final de venda se mantém em $\mathrm{R} \$ 2.500,00$, ele vai querer o crédito maior (ou seja, origem Sergipe e não Bahia).

Tudo depende da possibilidade do fabricante "empurrar" esse custo à jusante na cadeia de distribuição.

Uma possibilidade é o varejista não se importar com o crédito do ICMS: se o mesmo sonegar o ICMS (de forma total, simplesmente não emitindo a nota fiscal, ou parcial, 
como o expediente de "espelhar" a nota fiscal ${ }^{1}$ de venda ao consumidor, como ocorre com certos fornecedores), fica indiferente de onde ele recebeu a mercadoria (pois o desembolso, isto é, o preço pago pela mercadoria, é o mesmo). Como a esmagadora maioria das vendas de bens de consumo não-duráveis é realizada pela modalidade $\mathrm{CIF}^{2}$ (ou seja, fornecedor entrega), qualquer ganho logístico ou de ICMS ficaria então com a indústria.

Outra possibilidade seria não oferecer alternativa ao cliente a não ser o caminho mais vantajoso para a indústria, através de procedimentos comerciais assim ajustados e um projeto de rede logística adequado (não dando opções para o cliente): todo o ganho fica com o fornecedor. Entretanto, isto somente seria possível no caso de um mercado monopolista, onde a indústria forma seu preço. No caso de mercado onde há competição por preço, essas economias acabam sendo repassadas aos clientes.

$\mathrm{O}$ autor teve acesso a um bom exemplo deste último caso: observando o arquivo de notas fiscais de uma determinada indústria, observou-se campo específico chamado “desconto ICMS". Para vendas realizadas fora do Estado da indústria, esse desconto era exatamente a diferença de alíquotas intra e inter-estaduais de ICMS. O Quadro 2 a seguir exemplifica o que ocorre, com os valores normalizados em $\mathrm{R} \$ 100,00$ para facilitar a compreensão do exemplo e também preservar a privacidade da empresa.

Nesse caso, tem-se a fábrica localizada em São Paulo e o cliente em Minas Gerais. O preço ao consumidor pode ser assumido constante, pois ele é o mesmo dos dois lados da divisa. Assumindo margem de $15 \%$ (típica do setor supermercadista), o preço final então é de R \$115,00. Como fica o cálculo dos saldos de ICMS?

\footnotetext{
1 "Espelhar" a nota: expediente de emitir nota fiscal em valor inferior ao preço realmente transacionado.

${ }^{2}$ Por exemplo, as duas maiores cadeias supermercadistas do país compram mais de $95 \%$ de suas mercadorias CIF; uma das indústrias líderes de biscoitos vende mais de $70 \%$ na modalidade CIF, sendo que boa parte das vendas FOB provém de distribuidores do Norte/Nordeste que vão retirar das fábricas no Sudeste para se beneficiar da alíquota interestadual de $7 \%$.
} 


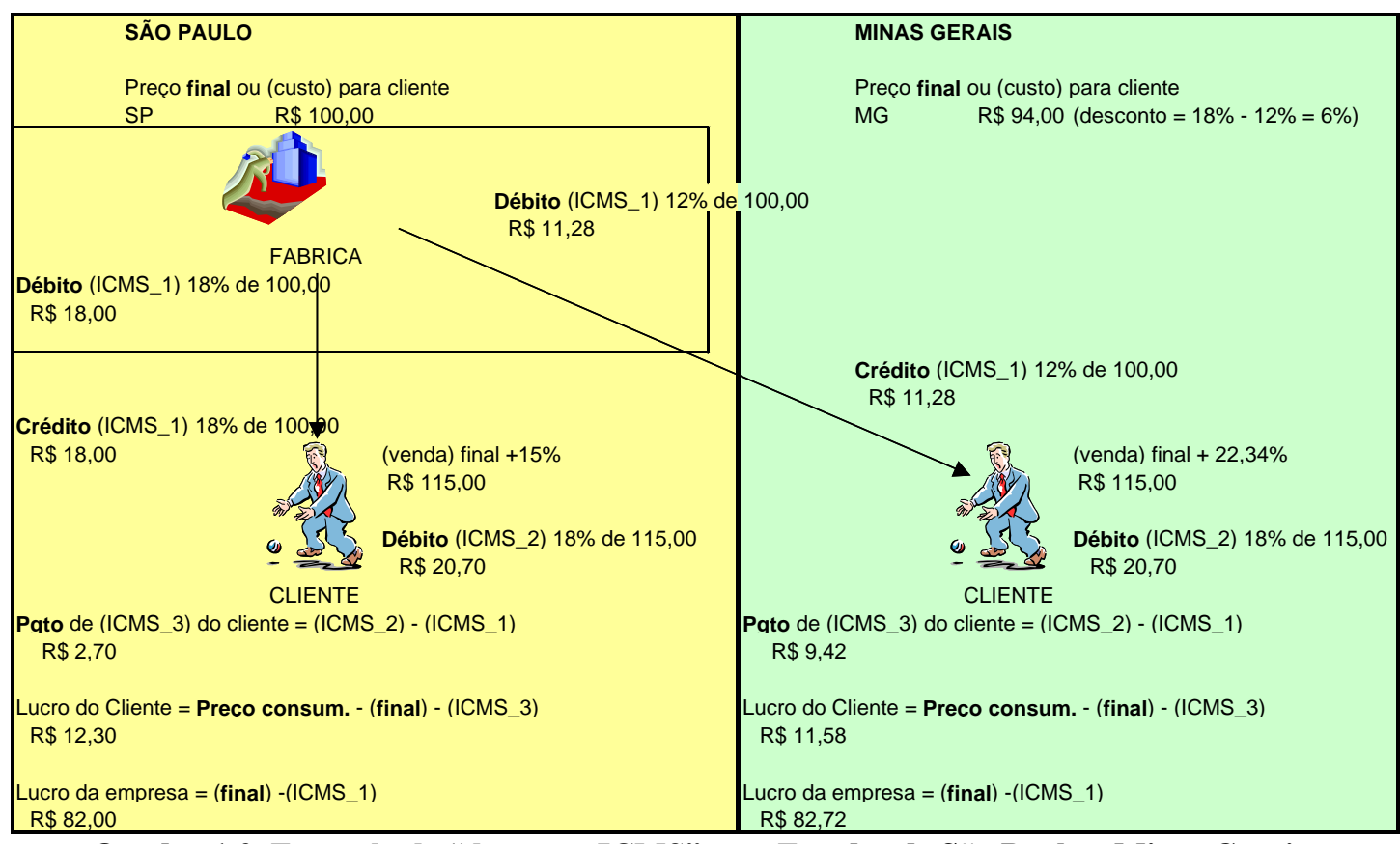

Quadro 1.2. Exemplo de "desconto ICMS" com Estados de São Paulo e Minas Gerais

O valor que a indústria almeja ganhar (custos mais margem) é R \$ 82,00 a unidade (canto inferior esquerdo); caso a venda ocorra em SP, o preço para o varejista é de $\mathrm{R} \$ 100,00$, pois se deve acrescer os $18 \%$ do imposto (parte esquerda do diagrama). Sobre esse preço "cheio", o fabricante dá um desconto de $6 \%$ para clientes em Minas, equivalente à diferença de alíquotas (18\% menos $12 \%)$, cobrando portanto o preço descontado de $\mathrm{R} \$ 94,00$ (lado superior direito do quadro). Assim, nos dois Estados, os lucros dos clientes e da empresa praticamente se mantém; a diferença de R \$ 0,72 entre os lucros em São Paulo e Minas se deve ao fato do desconto de 6\% ter sido calculado diretamente no preço ("por dentro"), quando na verdade deveria ter sido usada a razão da diferença (custo "por fora"), isto é, o desconto deveria ter sido calculado como $(1-0,18) /(1-0,12)=0,9318$, dando um preço de venda para o cliente de $\mathrm{R} \$ 93,18$.

No exemplo acima, o desconto é calculado de forma direta pela diferença de alíquotas. Isto acontece porque os preços de venda são os mesmos em ambos os Estados (fato razoavelmente comum no setor supermercadista) e, pela hipótese de mercado concorrencial, o repasse da diferença de ICMS é imposto à indústria. Não há vantagem no "turismo" de produtos, pois ninguém quebra a cadeia do tributo. 
A tabela 1.1 mostra a estrutura do arquivo de onde foi tirado o exemplo acima. Há casos de vendas para Minas Gerais (desconto de 6\%) e Bahia/Paraíba (desconto de $11 \%$ = diferença entre $18 \%$ de São Paulo e $7 \%$ nas vendas para o Nordeste). Reparar que o valor do desconto é calculado de forma direta ("por fora").

\begin{tabular}{|r|r|r|r|r|r|r|r|r|}
\hline Desc Icms & Valor Unitário & Qtde & Valor Descontos & Valor Liquido & Valor Faturado & Valor Frete na Nf & Emitente & Estado destino \\
\hline 0 & 100 & 1 & 0 & 100,00 & 100,00 & 0 & SP & SP \\
\hline 6 & 100 & 1 & 6,00 & 94,00 & 94,00 & 0 & SP & MG \\
\hline 11 & 100 & 2 & 22,00 & 178,00 & 178,00 & 0 & SP & BA \\
\hline 11 & 100 & 6 & 66,00 & 534,00 & 534,00 & 0 & SP & PB \\
\hline
\end{tabular}

Tabela 1.1. Extrato do arquivo de descontos logísticos usado.

Desta forma, caso o mercado seja competitivo no preço e não haja sonegação, o fabricante acaba repassando a variação de ICMS no seu preço.

Não há tradeoff entre Logística e ICMS; há contrapartida entre custos logísticos e sonegação do ICMS. Para perceber como isto torna o "turismo" de produtos interessante, é necessário olhar à jusante na cadeia de distribuição (isto é, além da indústria) para perceber esse tradeoff.

Assim, assuma-se que o fabricante está decidindo onde colocar seu $\mathrm{CD}$ e ele sabe que seu canal tem por prática sonegar o ICMS. Ele poderia montar uma operação de "turismo" de produtos, esquematizada abaixo no Quadro 1.3. Está-se assumindo os mesmos preços de venda do Quadro $1.2(\mathrm{R} \$ 100,00$ e $\mathrm{R} \$ 115,00$, para fabricante e varejista, respectivamente), para facilitar o raciocínio.

Na alternativa 1, o saldo de ICMS a recolher para a indústria é de $\mathrm{R} \$ 18$. Como na alternativa 2 o saldo é de apenas $\mathrm{R} \$ 12$, há vantagem econômica para a indústria, desde que a transação via depósito de Minas não prejudique as vendas pelo aumento da distância e conseqüente ampliação dos tempos de atendimento. A competitividade da empresa fica maior, podendo utilizar a redução no saldo a pagar do ICMS para aumentar suas margens ou reduzir preços para enfrentar a concorrência. A 
consequiência é a criação de um fluxo artificial de mercadorias entre os dois Estados, o "turismo" de produtos.

Ocorre evidentemente um aumento nos custos logísticos (transporte e armazenagem): há necessidade de verificar se o "turismo" compensa, considerando-se um custo total que englobe custos logísticos e a diferença do ICMS, possibilitada pela indiferença ao crédito do ICMS à jusante na cadeia comercial. Este é o tradeoff entre Logística e a sonegação do ICMS.

ALTERNATIVA 1 - SP-SP-SP (Logística normal)

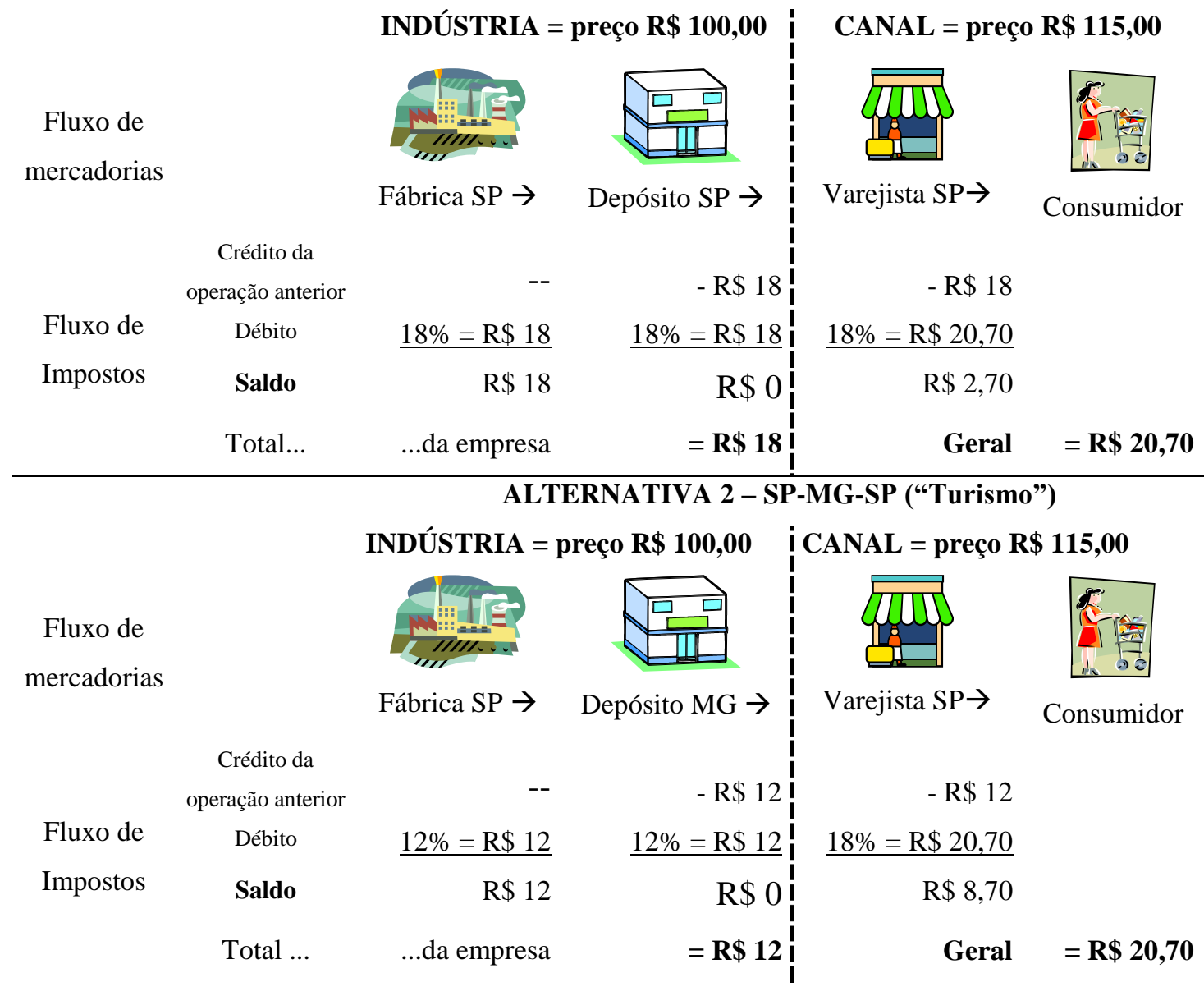

Quadro 1.3. Exemplo de “Turismo" na Cadeia do ICMS. 
Profissionais do ramo avaliam que o nível de sonegação de ICMS na cadeia de distribuição é muito alto, levando a muitos Estados tentarem criar formas alternativas de coibir essa prática, pois a fiscalização direta de todos estabelecimentos comerciais (há milhões de varejistas no país) é inviável. Um exemplo é a substituição tributária (tratada no item 2.7.2, Capítulo 2). Outra é cobrar a diferença do ICMS diretamente do transportador nos postos de fiscalização na fronteira dos Estados (como ocorre em certas épocas do ano e para certas mercadorias no Nordeste). De qualquer forma, há condições objetivas para as indústrias utilizarem o expediente do turismo de mercadorias em seu favor.

\subsubsection{Conclusão: justificando o tema}

É assim surpreendente que a literatura disponível de Logística no país explore esse problema de maneira basicamente qualitativa, havendo poucos estudos divulgados que tenham metodologia consistente e abrangente para avaliar a influência do ICMS. Títulos didáticos recentes, como Novaes (2001), Novaes e Alvarenga (2000) e Fleury (2000), não citam a existência do ICMS ou como este afeta a Logística (ou mesmo outros impostos).

Novaes (1989, p. 207 a 235) comenta rapidamente o aspecto tributário na Logística ao apreciá-los na modelagem do problema de localização de centros de distribuição (CD’s): o tributo é considerado apenas item adicional de custo variável, como fretes ou seguros. Entretanto, não se explora a fundo a questão tributária e seu efeito na Logística. Nesta pesquisa se verifica que é possível modelar a estrutura do ICMS (imposto indireto) como custo variável dependente do produto, da sua origem e destino (como um custo de transporte), corroborando a hipótese daquele autor.

Ribeiro (1999) faz uma excelente revisão sobre a questão tributária nacional e seu interregno com a Logística. Esse autor detalha todos os tributos diretos e indiretos mas desenvolve um caso em que trabalha apenas com o ICMS para a distribuição física de produtos acabados. Ribeiro modela um problema de caminho mínimo que encontra a rota de menor custo total (transporte mais ICMS) conforme a origem e o 
destino. Assim, considera a rede logística já estabelecida e todos os custos modelados são variáveis. Seu objetivo é demonstrar que a empresa do caso pode ter uma distribuição mais econômica caso considere custos logísticos e ICMS simultaneamente.

Ao considerar apenas o sistema formado pela empresa-objeto, Ribeiro assume implicitamente que todos os clientes são indiferentes quanto ao crédito do ICMS ou que a empresa pode definir a origem de qualquer fornecimento, mesmo que isto signifique empurrar imposto na cadeia. Além disso, não leva em conta custos fixos logísticos e, portanto, a instalação e a localização dos depósitos não é variável de decisão. Porém, há na prática razoável flexibilidade para se montar a rede física de distribuição e, desta forma, influenciar custos logísticos e o ICMS pago concomitantemente. Finalmente, esse autor utiliza valores fictícios para seus produtos e os valores de fretes são tirados diretamente das planilhas publicadas pela Associação Nacional de Transporte de Carga (NTC), que estão sempre significativamente superiores aos fretes praticados no mercado.

Nesta pesquisa tais limitações foram suplantadas, pois:

a) A indiferença do canal frente ao crédito de ICMS é modelada pela proporção de clientes interessados no crédito (maiores discussões no Capítulo 3), o que permite ver a influência da sonegação nas decisões logísticas;

b) A instalação de depósitos ou centros de distribuição é variável de decisão, pois custos fixos são explicitamente incorporados ao modelo de análise; não apenas a rota ótima é determinada, mas também a melhor alternativa é construída pelo modelo de otimização, abrindo-se CD's quando esta for a opção ótima; assim, projeta-se a rede logística de instalações que otimiza o custo total (Logística + ICMS);

c) Todos os custos e valores considerados são reais (valores base de Novembro de 2000), obtidos a partir de empresas fabricantes e distribuidoras de bens de consumo não-duráveis, que colaboraram fornecendo dados, desde que garantido seu anonimato. Por outro lado, foram empregados dados fidedignos de demanda para a construção dos cenários de análise. 
Assim, foi possível tirar conclusões que permitem razoável grau de generalização. A finalidade básica desta pesquisa é discutir o entrelaçamento entre Logística e ICMS e iluminar um pouco este assunto e não somente apresentar uma nova metodologia para projeto de sistemas de distribuição. Nisto ela tem sua principal contribuição ao estudo da Logística no país.

Sinteticamente, o problema aqui estudado é como desenhar a rede física de centros de distribuição ou depósitos que minimize o custo total (logístico e ICMS) sob o ponto de vista de fabricantes de mercadorias do tipo encontrado em estabelecimentos supermercadistas. Para isto, é montado um modelo matemático de otimização que constrói a rede, localizando os diversos centros de distribuição desse fabricante em municípios tais que minimizem o custo logístico e o ICMS a ser recolhido, mesmo que às custas de gerar "turismo" de produtos. Portanto, poder-se-á verificar o impacto da estrutura do ICMS e da sonegação pelo canal nos custos logísticos, isto é, qual deverá ser o incremento justificado nos custos de transporte e de armazenagem para reduzir o ICMS pago pelo fabricante. Assim, é possível avaliar o tradeoff entre logística e sonegação do ICMS.

\subsection{Visão geral da tese}

A tese está subdividida em cinco capítulos:

- Capítulo 1: define objetivos da tese, introduz o tema e justifica sua importância, mostrando exemplos didáticos da inter-relação entre decisões logísticas e tributárias.

- Capítulo 2: trata da revisão da literatura; conceitos relevantes, como Logística, Gerenciamento da Cadeia de Suprimentos, Enfoque Sistêmico, Hierarquia de Decisões, Localização Industrial e de Depósitos, Tributação e trabalhos prévios são discutidos e comentados. 
- Capítulo 3: descreve a metodologia empregada e a modelagem do problema de projeto de redes logísticas considerando-se a estrutura de ICMS, assim como as hipóteses empregadas; uma descrição detalhada do caso base do estaduo é feita; o cálculo e a determinação dos parâmetros são detalhados aqui; as ferramentas computacionais empregadas são listadas.

- Capítulo 4: mostra os resultados obtidos e faz uma análise sucinta dos mesmos.

- Capítulo 5: faz uma discussão geral dos resultados e faz as conclusões finais; propostas de continuidade da pesquisa são apresentadas. 


\section{REVISÃO DA LITERATURA}

Este capítulo discorre sobre conhecimentos específicos que são importantes para o desenvolvimento das idéias contidas nesta tese. Em seqüência, tem-se:

- Logística e Distribuição Física

- Gerenciamento da Cadeia de Suprimentos (Supply Chain Management)

- Enfoque sistêmico

- Custo total

- Hierarquia de decisões

- Projeto de cadeias de distribuição (modelos de localização)

- A questão tributária e o ICMS

- Trabalhos prévios de Logística e ICMS

\subsection{Logística e Distribuição Física}

Conforme Ballou (1999, Cap.1), o Council of Logistics Management define Logística como:

"Logística é o processo de planejar, implementar e controlar o fluxo e a armazenagem eficientes e eficazes de matérias-primas, estoque em processo, produtos acabados e informação relacionada desde o ponto de origem até o ponto de consumo, com o propósito de atender os requisitos dos clientes."

O mesmo autor comenta que uma única empresa geralmente não controla todo o canal de produtos, desde as fontes de matérias-primas até os pontos de consumo final. Para finalidades práticas, a logística de uma firma individual tem um escopo mais estreito, geralmente se restringindo aos canais de fornecimento e distribuição física imediatos, como pode ser visto na Figura 2.1. O canal de suprimento se refere à ligação entre as fontes adjacentes de materiais para a companhia e seus pontos de processamento (no caso de indústrias, suas fábricas; no caso de atacadistas ou 
distribuidores, seus depósitos ou armazéns). O canal de distribuição física diz respeito ao movimento dos produtos acabados da empresa para seus clientes imediatos; no caso de indústrias, o fluxo vai de suas fábricas ou depósitos para estabelecimentos comerciais, como atacadistas, distribuidores ou varejistas, que disponibilizarão as mercadorias para os consumidores finais.

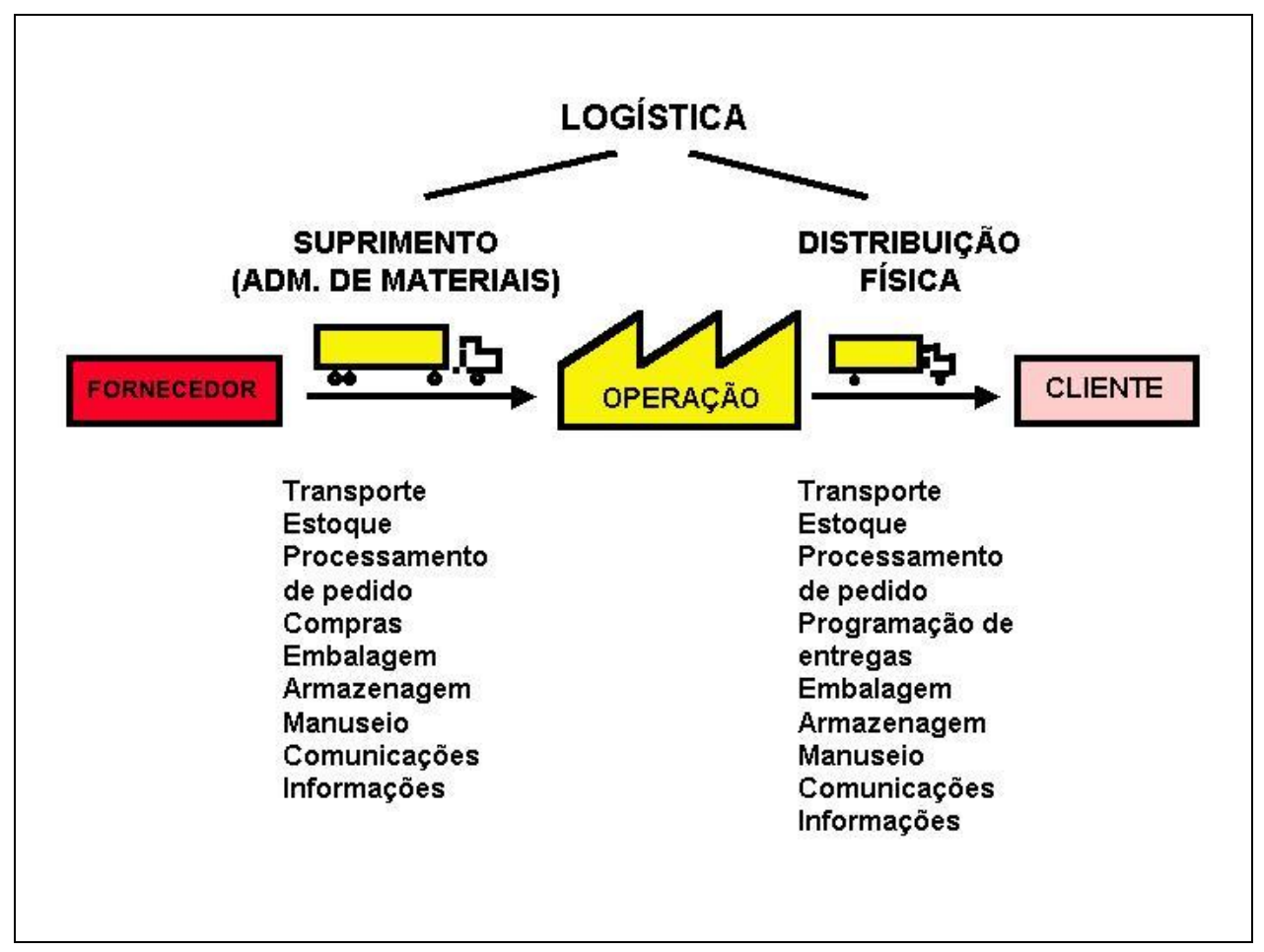

Figura 2.1. Atividades da Logística (adaptado de Ballou, 1999).

Como a Figura 2.1 mostra, as atividades em ambos os canais (a jusante e a montante da companhia) são: transporte, manutenção dos estoques, processamento de pedidos, compras/programação de entregas, embalagem, armazenagem e manuseio de materiais.

A Logística tem se firmado como conceito e disciplina essencial para a área empresarial brasileira nos últimos anos, resultado de pressões para redução de custos e aumento do nível de serviço, por um lado, e pela maior disponibilidade de opções de modais e serviços, de outro (Fleury, 2000; Novaes, 2001). 
Conforme comentado, esta tese trata especificamente da inter-relação entre a Logística e o ICMS no canal de distribuição física para bens de consumo nãoduráveis, encontrados em estabelecimentos de auto-serviço (supermercados e congêneres) e de varejo tradicional (mercearias, quitandas, padarias, farmácias etc). Esse canal costuma se segmentar em vários sub-canais paralelos, alguns deles com múltiplos estágios, como a Figura 2.2 esquematiza.

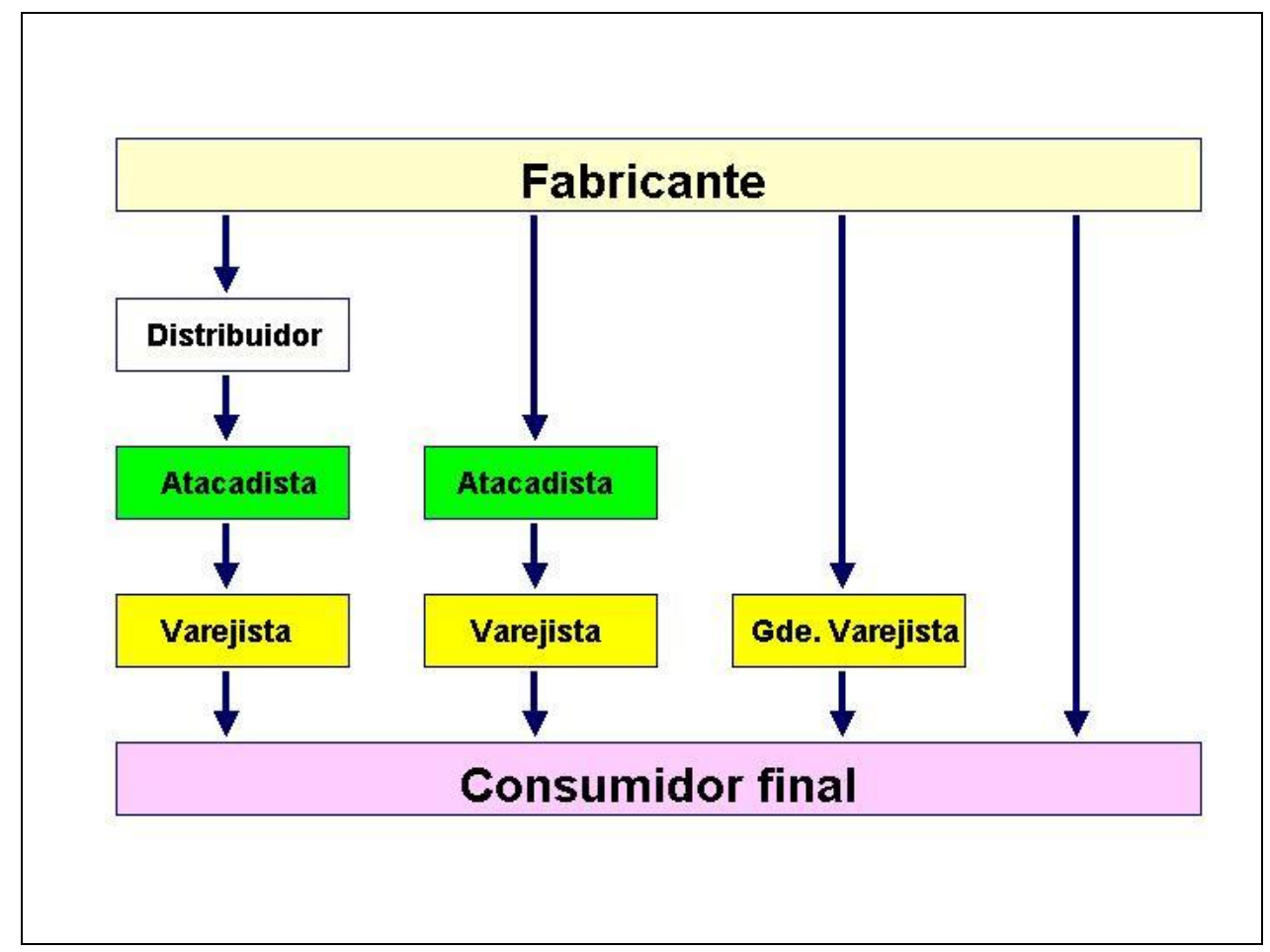

Figura 2.2. Exemplo de estrutura de canal para bens de consumo não-duráveis (adaptado de Bowersox e Closs, 1996, Cap. 4)

A maioria dessas indústrias adota a estrutura multi-canal: para atender um varejo extremamente pulverizado, elas se valem de intermediários como distribuidores (revendem exclusivamente os produtos com a marca da companhia) e atacadistas (sem exclusividade). Isto permite às indústrias atuarem em mercados onde não teriam escala suficiente para operações econômicas ou se concentrarem na produção e marketing institucional de seus produtos. Grandes clientes (chamados de clienteschave), como as grandes redes de supermercados (a rede Extra/Pão de Açúcar, Carrefour, Sonae, etc) ou atacado (Macro, Martins), costumam ser abastecidos 
diretamente e representam, tipicamente, de 15 a $20 \%$ das vendas em volume dessas indústrias. Uma segmentação típica de canal está na Tabela 2.1 abaixo.

\begin{tabular}{|l|c|c|}
\hline \multirow{2}{*}{ Canal de vendas } & \multicolumn{2}{|c|}{} \\
\cline { 2 - 3 } & Bipo de Indústria \\
\hline Clientes-chave & $15 \%$ & Refrigerantes** \\
\hline Distribuidores/Atacadistas & $33 \%$ & - \\
\hline Varejo supermercadista & $52 \%$ & $42 \%$ \\
\hline Mercearias/ bares/restaurantes & - & $44 \%$ \\
\hline $\begin{array}{l}(*) \text { dados referentes a 2001 para uma das três marcas líderes } \\
(* *) \text { dados referentes a 2000 para uma das três marcas líderes }\end{array}$ \\
\hline
\end{tabular}

Tabela 2.1. Segmentação típica de canal para fabricantes de bens de consumo não-duráveis, em volume de produto.

Uma rápida avaliação da tabela mostra a concentração de vendas nos poucos clientes-chave (de seis a quinze clientes, conforme a empresa), dentro de um universo com dezenas de milhares de clientes ativos nesse tipo de empresas. Naturalmente, chegar no pequeno varejo requer um esforço hercúleo do ponto de vista da distribuição física, o que explica o uso de distribuidores e atacadistas, como feito, por exemplo, pelos fabricantes de bolachas, doces e chocolates.

Distribuidores e atacadistas têm um papel econômico e logístico fundamental, pois conseguem ganhar escala de operação pela consolidação da carga de diversos fornecedores e clientes (Ballou, 1999, Cap. 2). Economias de escala são particularmente importantes em Logística, pois o transporte de produtos tem grandes economias de escala (Novaes, 1987;1989). Há também economias de escala na operação de armazéns e centros de distribuição (Fundação Vanzolini, 2000).

Mais recentemente, surgiu um novo ator no palco da Logística brasileira que pode suprir esse ganho de escala até então obtido por intermédio de distribuidores e atacadistas: o operador logístico. O operador logístico é, conforme definição da Associação Brasileira de Movimentação e Logística - AMBL (1999): 
“Operador Logístico é o fornecedor de serviços logísticos, especializado em gerenciar e executar todas ou parte das atividades logísticas nas várias fases da cadeia de abastecimento de seus clientes, agregando valor aos produtos dos mesmos, e que tenha competência para, no mínimo, prestar simultaneamente serviços nas três atividades básicas de controle de estoques, armazenagem e gestão de transportes".

O operador logístico, ao atender na mesma instalação (depósito ou CD) produtos provenientes de diversas indústrias, ganha escala na armazenagem e no transporte de transferência; caso os produtos que manuseie sejam entregues no mesmo canal, pode-se ganhar escala também no transporte de ponta, de forma semelhante à operação física de um distribuidor de produtos. Foi, por exemplo, a concepção empregada pela Philip Morris do Brasil ${ }^{3}$, ao concentrar a distribuição física de suas empresas (Lacta, chocolates; Kraft Foods, balas e confeitos; Philip Morris, cigarros) em um só operador logístico, pois o canal de vendas é basicamente o mesmo.

A possibilidade de diluir custos fixos de instalações em vários clientes torna o operador logístico uma opção atraente para as indústrias de varejo. Diversas empresas têm passado a distribuição física para esses terceiros, conseguindo reduzir custos sem perder qualidade no serviço de entrega. Isto significa se desfazer de ativos (grandes indústrias multinacionais mantinham uma estrutura logística com vários CD’s distribuídos pelo país, via de regra nas grandes capitais), que passam aos operadores, os quais colocam outros clientes na mesma instalação. Esses outros clientes podem inclusive ser indústrias menores que não tinham condições de arcar com uma estrutura própria.

Isto não significa que as indústrias vão prescindir de intermediários (atacadistas e distribuidores), pois estes não realizam apenas a logística de seus produtos acabados. Uma de suas contribuições mais importantes é a capacidade comercial, isto é, a competência de realizar a pulverização das vendas. Eles detêm conhecimento detalhado do pequeno varejo que muitas grandes indústrias não têm, pois lidam com

\footnotetext{
${ }^{3}$ Entrevista com o sr. Ozoni Argenton, ex-diretor de Logística da Philip Morris, em Maio de 1998.
} 
o mesmo diuturnamente. Além disso, intermediários se prestam a realizar esquemas comerciais com o pequeno varejo que as grandes indústrias têm dificuldade em operacionalizar (por exemplo, por questões de financiamento ou risco de crédito).

Os conceitos acima são importantes para se entender a montagem do problema básico do Capítulo 3, em particular, o ganho de escala possibilitado pelo operador logístico.

\subsection{Gerenciamento da Cadeia de Suprimentos (Supply Chain Management)}

Apesar de ser considerado por determinados autores (Ballou, 1999, Cap.1; SimchiLevi; Kaminsky; Simchi-Levi, 2000, cap.1) apenas um outro nome para a disciplina de Logística Empresarial, outros autores (Lee, 1995; Lambert, 1998) consideram o Gerenciamento da Cadeia de Suprimentos um ramo da Administração de Empresas diferente da Logística. Neste trabalho é adotada a definição de Lambert (1998):

"Administração da Cadeia de Suprimentos é a integração dos processos de negócio desde o usuário final até os fornecedores originais que proporcionam os produtos, serviços e informações que agregam valor para o cliente"

A cadeia de suprimentos é a mesma cadeia logística do item anterior, que também vai do fornecedor da matéria-prima original até o consumidor final. Mas, apesar dessa definição um tanto abrangente, pode-se perceber a ênfase na integração de processos. Para Lambert, o fluxo físico de produtos envolve também a função de transformação da cadeia (ou seja, a manufatura); desta forma, a gestão do fluxo físico dos materiais dentro da fábrica e seus estoques também são objeto da Administração da Cadeia de Suprimentos (Supply Chain Management em inglês, cuja sigla é SCM). Desta maneira, o Planejamento e Controle da Produção - PCP - estão envolvidos no SCM, formando agora uma gestão unificada do fluxo de materiais junto com a Logística (Shapiro, 2001, p.17). 
Outros processos que esse autor também incorpora ao SCM são o Projeto de Produtos (que define a priori boa parte dos custos logísticos) e a Gestão do Fluxo Financeiro. Esses pontos são pouco relevantes na discussão dos conceitos empregados nesta tese e não serão detalhados.

O SCM exige um incremento da visão externa à companhia. Por exemplo, decisões devem ser tomadas considerando o impacto ao longo de toda a cadeia para aumentar a competitividade da mesma para o consumidor final. Nesse sentido, há ênfase em se fugir de relacionamentos com fornecedores ou clientes que sejam jogos de soma zero: colaboração e parcerias de longo prazo são as "sugestões do chef" no cardápio do SCM, obtidas através de esquemas ganha-ganha. Para isto é fundamental se conhecer os esquemas de recompensa ao longo da cadeia e, conforme o caso, realinhar os mesmos, eliminando ou reduzindo os tradeoffs que ocorrem entre os membros da cadeia.

Um exemplo clássico do SCM é a filosofia inerente ao movimento Efficient Consumer Response (ECR), iniciado há cerca de uma década nos E.U.A. e que vem tentando aproximar as indústrias (fornecedores) e o varejo supermercadista. A idéia básica é que, para o varejo, a perda de vendas ocasionada pelo desabastecimento das lojas sobrepujaria os ganhos obtidos com negociações de preço por volume para obtenção de descontos de compra das indústrias. Assim, ao invés de "espremer" a indústria para obter descontos, o varejo deveria aliar-se à mesma para maximizar o nível de serviço disponibilizado ao consumidor final. Afinal, "a Coca-Cola que não se bebe hoje não será bebida amanhã”, ou seja, a perda de vendas ocorre para ambos os estágios da cadeia de suprimentos.

Desta maneira, o SCM tenta expandir as fronteiras do sistema a ser avaliado no fluxo de materiais, possibilitando assim otimizar outros tradeoffs: internamente à indústria, pela incorporação do PCP e do Projeto de Produtos, e externamente à firma, ao buscar os tradeoffs com outros membros a montante ou jusante no fluxo logístico. Por isto, é um conceito importante para a discussão da tese: é o conhecimento do 
tradeoff entre crédito de ICMS do cliente e a origem do produto (fornecedor) que permite a modelagem desenvolvida nesta pesquisa.

\subsection{Enfoque Sistêmico aplicado à Logística}

A idéia do enfoque sistêmico (Churchman, 1971; Ballou, 1992, p. 47; Novaes e Alvarenga, 2000, Cap. 1) aplicada à administração de operações não é nova. No caso específico da Logística, seu uso facilita o entendimento dos seus problemas e a busca por soluções ótimas.

Sistema é um conjunto de elementos que interagem entre si e que tem propriedades diferentes de qualquer um de seus elementos (Ackoff e Gharajedaghi, 1996). Essas propriedades que diferenciam o sistema de seus elementos componentes são chamadas de propriedades emergentes.

Eles podem ser classificados de diversas maneiras: uma quebra normal é dividi-los em naturais (produzidos pela Natureza) e artificiais (produzidos pelo homem). Sistemas naturais não tem finalidade intrínseca aos mesmos; sistemas artificiais podem ter uma ou várias finalidades, como uma firma (obter lucro ou sobreviver) ou uma escola (ensinar e formar cidadãos). Para sistemas artificiais com finalidade, como é o caso de empresas, a explicitação de seus objetivos é fundamental para a compreensão de seu comportamento no ambiente onde operam.

A aplicação do enfoque sistêmico leva inevitavelmente à questão da hierarquia de componentes. Usando uma analogia, sistemas podem ser comparados a um conjunto de caixas chinesas, uma menor dentro da outra maior de forma infinita: componentes são sub-sistemas que têm uma finalidade compreensível dentro da sua inter-relação com outros componentes de seu nível hierárquico. Esse componente, por sua vez, é formado por outros elementos menores (sub-sub-sistemas), que são formados por outros menores e assim por diante. 
O caminho inverso também é possível: qualquer sistema pode ser considerado como parte de algo maior (super-sistema), que é elemento de algo ainda maior, etc.

Conforme Ackoff (1974), sistemas são em princípio indivisíveis, e a redução em subsistemas é uma aproximação indesejável. A priori, enxergar-se uma organização como um sistema implica aceitar sua indivisibilidade. Conforme Yoshizaki (1997, Cap. 2), temos a tradicional questão dos sub-ótimos (o todo é maior que a soma das partes), gerados pelo emprego de pontos de vista locais ou parciais.

Olhando a Logística sob este prisma, não é suficiente que cada atividade (transportes, estoques, processamento de pedido, etc) opere no seu melhor desempenho individual. Isto acontece porque há conflito entre as diversas atividades logísticas (ver item seguinte). O modelo de empresa (ou do processo logístico) como um sistema não é nada neutro: ele exige o posicionamento de cada sub-sistema componente como subserviente aos objetivos da organização. Como o desempenho de cada parte da organização é medido conforme índices definidos por ela mesma, o correto projeto dos objetivos individuais é fundamental para garantir a cooperação de cada atividade.

Se já é complexo tratar uma organização ou processo dessa organização como um sistema, como faz a moderna Logística Empresarial (Ballou, 1992; Novaes e Alvarenga, 2000), o que dizer de uma cadeia de suprimentos, onde temos diversas organizações com conflitos reais entre si (jogo de soma zero)? Definições de Gerenciamento da Cadeia de Suprimentos (Lambert, 1998; Bowersox e Closs, 1996, Cap. 2 e 4) colocam que o objetivo do mesmo (a propriedade emergente) é aumentar a competitividade da cadeia com um todo ao garantir o atendimento do consumidor final com melhor qualidade e preço. Assim, tenta-se obter eficiências pela eliminação de atividades que não agregam valor na cadeia (como atividades duplicadas ou certos custos ex ante e ex poste, tais quais custos de negociação de pedidos ou inspeções de qualidade) ou pelo reconhecimento e equilíbrio de tradeoffs entre os seus membros. 


\subsection{Custo total}

O conceito do custo total é central no escopo e no projeto de sistemas logísticos (Ballou, 1992, Cap. 3; 1999, Cap.2; Bowersox e Closs, 1996, Cap. 1 e 17; Magee, 1968) e está fundamentado na análise de conflitos entre as diversas atividades logísticas, isto é, na análise dos tradeoffs que ocorrem entre elas. Foi enunciado pela primeira vez na década de 1950 (Bowersox e Closs, 1996, p.10) em relatório da Harvard University, onde se analisava a competitividade do transporte aéreo de cargas comparado com outros modais: os autores constataram que, para certos tipos de mercadorias (de alto valor agregado e baixa densidade, como produtos eletrônicos), o maior valor do frete aeronáutico era mais que compensado pelo menor custo de estoques, decorrente de sua maior velocidade (diminuindo o estoque em trânsito) e confiabilidade (reduzindo a necessidade de estoques de segurança). Portanto, a idéia é balancear atividades em conflito (no caso acima, transporte e manutenção de estoque) de forma que elas sejam otimizadas coletivamente.

Conflitos clássicos entre atividades logísticas são (Ballou, 1999, Cap. 2):

- Modal de transporte versus manutenção de estoque: mencionado acima, quanto mais rápido e confiável, mais caro é o modal de transporte; por sua vez, velocidade e confiabilidade reduzem custos de estoque; além disso, modais mais lentos tendem a exigir lotes mínimos de transportes maiores e, portanto, levam a maiores estoques nas pontas; balancear transporte e estoque talvez seja o conflito mais comum em Logística;

- Disponibilidade de estoque versus falta: quanto maior a disponibilidade de material (e, portanto, maior o nível de serviço assim mensurado), maior o custo de manutenção de estoques; em compensação, reduz-se o custo de oportunidade associado à falta do material (como perda de vendas ou paradas de produção);

- Número de depósitos no sistema de distribuição física versus custos: quanto maior o número de depósitos, maior o nível de serviço ao cliente (medido como rapidez de entrega e disponibilidade de produtos) e a receita; além disso, reduzem-se os custos de transporte para entrega; entretanto, 
elevam-se os custos de armazenagem (custos fixos das instalações), estoques (aumento do estoque total no sistema, pelo incremento no estoque de segurança) e, a partir de certo ponto, os custos de transporte não se reduzem mais;

- Tamanho do lote de produção e manutenção de estoques: quanto maior o tamanho do lote de produção, menor o número de setups e, portanto, menor o custo unitário de produção; porém, aumenta-se o estoque médio e, por decorrência, os custos de manutenção de estoques.

O custo total é uma propriedade emergente do sub-sistema logístico de uma companhia, caso se assuma utilizar o enfoque sistêmico neste processo.

Na prática empresarial nem sempre é fácil obter essa visão sistêmica e se operar com custos totais otimizados. Isto acontece por diversos motivos: falta de conhecimento dos diversos tradeoffs que ocorrem na organização (visão mecanicista das atividades logísticas); medidas de mérito (indicadores de desempenho) funcionais e não por processo (otimização individual ao invés de coletiva), levando a uma visão estanque das operações; impossibilidade política de se rever a forma de recompensas na empresa ou entre os membros da cadeia de suprimentos; etc.

\subsection{Hierarquia de decisões}

Conforme Yoshizaki (1997, Cap. 4), “adotar uma abordagem sistêmica implica aceitar que propriedades emergentes estão associadas a hierarquias. Para evitar subótimos, portanto, o emprego de um enfoque top-down, ou seja, de um processo de desagregação coerente, surge de maneira natural... Métodos top-down, como a Teoria Geral de Sistemas de Mesarovic e Takahara (1975), a administração por objetivos e o planejamento hoshin (Shiba et al., 1993), sempre estiveram baseados em uma visão hierárquica de sistemas. Nestes métodos, a idéia fundamental é garantir a coerência dos objetivos e metas dos sub-sistemas de uma organização pela desagregação paulatina (à medida que se 'desce' na estrutura organizacional, no caso de 
organizações tradicionais) dos supra-objetivos para os objetivos dos sub-sistemas. Isto requer conhecimento preciso de interdependências entre funções (Thompson, 1967; March e Simon, 1958) e da existência ou não de trade-offs entre as mesmas."

A necessidade de uma hierarquia de decisões ou níveis de planejamento também é reconhecida por outros autores (Hax e Candea, 1980; Santoro, 1991; Ballou, 1999; Shapiro, 1999; 2001), sendo nível de planejamento definido pelo seu horizonte de tempo. De forma esquemática e clássica, divide-se a hierarquia em três patamares: estratégico, tático e operacional.

O nível estratégico tem o horizonte mais longo (maior que um ano) e, por isso, freqüentemente é obrigado a usar dados pouco precisos ou incompletos, daí se utilizar dados agregados. Mas é o nível com maior flexibilidade, pois no longo prazo qualquer mudança no sistema logístico pode ser projetada e implantada. O nível tático envolve horizontes intermediários, geralmente menos de um ano. Aqui a flexibilidade também é intermediária: por exemplo, em planejamento agregado da produção a capacidade física de uma fábrica é fixa, mas pode-se variar a produção da mesma com horas-extras, admissão e demissão de pessoal. O nível de detalhe de dados é médio. Finalmente, o nível operacional faz a tomada de decisão de curto prazo, com horizonte que pode ser tão pequeno como semanas ou dias e freqüência de decisão diária ou mesmo de algumas horas. Nesse nível, a flexibilidade de alterações no sistema física é mínima e o nível de detalhe máximo, trabalhando-se itens individuais. 


\begin{tabular}{|c|c|c|c|c|c|c|}
\hline $\begin{array}{l}\text { Nivel de } \\
\text { decisão }\end{array}$ & $\begin{array}{l}\text { Localiza- } \\
\text { ção }\end{array}$ & $\begin{array}{c}\text { Transpor- } \\
\text { tes }\end{array}$ & Estoques & $\begin{array}{l}\text { Proc. do } \\
\text { pedido }\end{array}$ & $\begin{array}{c}\text { Armazena- } \\
\text { gem }\end{array}$ & Compras \\
\hline $\begin{array}{l}\text { ESTRA- } \\
\text { TEGGICO }\end{array}$ & $\begin{array}{c}\text { Número, } \\
\text { tamanho e } \\
\text { localizaçẫo } \\
\text { de } \\
\text { instalaçốes }\end{array}$ & $\begin{array}{l}\text { Seleção do } \\
\text { modal }\end{array}$ & $\begin{array}{l}\text { Políticas de } \\
\text { estoque, } \\
\text { rotatividade }\end{array}$ & $\begin{array}{l}\text { Projeto do } \\
\text { sistema de } \\
\text { proc. do } \\
\text { pedido }\end{array}$ & $\begin{array}{l}\text { Layout; } \\
\text { seleçẫo de } \\
\text { equipamen- } \\
\text { to de } \\
\text { manuseio }\end{array}$ & $\begin{array}{l}\text { Políticas de } \\
\text { relaciona- } \\
\text { mento }\end{array}$ \\
\hline TÁTICO & $\begin{array}{l}\text { Posiciona- } \\
\text { mento do } \\
\text { estoque }\end{array}$ & $\begin{array}{l}\text { Aluguel } \\
\text { sazonal de } \\
\text { equipa- } \\
\text { mento }\end{array}$ & $\begin{array}{l}\text { Estoque de } \\
\text { segurança, } \\
\text { regras de } \\
\text { controle }\end{array}$ & $\begin{array}{l}\text { Regras de } \\
\text { prioridades }\end{array}$ & $\begin{array}{c}\text { Utilizaçẫo } \\
\text { do espaço; } \\
\text { escolhas } \\
\text { sazonais }\end{array}$ & $\begin{array}{l}\text { Contrata- } \\
\text { çẫo } \\
\text { seleçã de } \\
\text { fornecedo- } \\
\text { res }\end{array}$ \\
\hline $\begin{array}{l}\text { OPERA- } \\
\text { CIONAL }\end{array}$ & $\begin{array}{c}\text { Determinação } \\
\text { de carga }\end{array}$ & $\begin{array}{l}\text { Roteiriza- } \\
\text { çẫo, } \\
\text { agenda- } \\
\text { mento e } \\
\text { despacho }\end{array}$ & $\begin{array}{c}\text { Reposiçẫo } \\
\text { (quantida- } \\
\text { dese } \\
\text { prazos) }\end{array}$ & $\begin{array}{l}\text { Atendimen- } \\
\text { to }\end{array}$ & $\begin{array}{l}\text { Coleta e } \\
\text { arrumaçẫo }\end{array}$ & $\begin{array}{l}\text { Liberação } \\
\text { de pedidos }\end{array}$ \\
\hline
\end{tabular}

Figura 2.3. Exemplo de hierarquia de decisões em Logística.

Adotando-se uma abordagem hierárquica da problemática da tese (a questão da interrelação entre a Logística do produto acabado e o ICMS) e aplicando-se o conceito de escada da abstração (Hayakawa e Hayakawa, 1990; Yoshizaki, 1997, cap. 5), no nível operacional ter-se-ia o problema de curto prazo: dada a venda de um item e a disponibilidade do mesmo nas diversas instalações (almoxarifados das fábricas e depósitos da empresa), encontrar a rota de menor custo total (no caso, transporte e ICMS) para atender um cliente. Repare-se que a estrutura logística (depósitos das fábricas e CD's) está fixa. No nível tático, o problema fica: dada uma rede logística já definida (depósitos das fábricas e CD's), determinar qual instalação deve atender qual cliente de qual produto, ou seja, um problema de posicionamento de estoque e área de influência da instalação que minimize o custo total (transporte, estoque e ICMS). Finalmente, no nível estratégico (longo prazo), pode-se projetar uma rede logística (depósitos) que minimize o custo total (fixos e variáveis das instalações, transporte, estoque e ICMS) para atender uma demanda espacialmente distribuída de todos os produtos. 
A Tabela 2.2 a seguir ilustra a escada de abstração associada à hierarquia de decisão do problema logística vs ICMS.

\begin{tabular}{|c|c|c|c|}
\hline $\begin{array}{l}\text { Nível de } \\
\text { Decisão }\end{array}$ & $\begin{array}{c}\text { Ambiente } \\
\text { (aquilo que está fixado } \\
\text { para decisão) }\end{array}$ & $\begin{array}{c}\text { Objetivo: } \\
\text { minimizar custo total } \\
\text { (custos componentes abaixo } \\
\text { relacionados) }\end{array}$ & $\begin{array}{c}\text { Variável de Decisão } \\
\text { (o que pode ser alterado) }\end{array}$ \\
\hline Estratégico & $\begin{array}{l}\text { Produtos } \\
\text { Demanda por município } \\
\text { Custos fixos e variáveis } \\
\text { (instalações e transporte) } \\
\text { Nível de serviço (prazo de } \\
\text { entrega) }\end{array}$ & $\begin{array}{l}\text { Transporte: fábrica-CD } \\
\text { (transferência), fábrica- } \\
\text { cliente e CD-cliente (entrega) } \\
\text { Manutenção do estoque } \\
\text { (financeiro) } \\
\text { Manuseio nos CD: fixos e } \\
\text { variáveis } \\
\text { ICMS }\end{array}$ & $\begin{array}{l}\text { Onde localizar depósitos } \\
\text { ou CD's } \\
\text { Agregado por famílias. }\end{array}$ \\
\hline Tático & $\begin{array}{l}\text { Tudo acima, mais } \\
\text { localização atual de } \\
\text { fábricas e CD's }\end{array}$ & $\begin{array}{l}\text { Transporte (idem acima) } \\
\text { Manutenção do estoque } \\
\text { (financeiro) } \\
\text { Manuseio no CD: variáveis } \\
\text { ICMS }\end{array}$ & $\begin{array}{l}\text { Onde posicionar os } \\
\text { estoques (que item ou } \\
\text { família vai para qual CD) } \\
\text { Área de influência dos } \\
\text { CD's, por produto }\end{array}$ \\
\hline Operacional & $\begin{array}{l}\text { Pedido do cliente } \\
\text { Posição atual dos estoques. } \\
\text { Custos variáveis }\end{array}$ & $\begin{array}{l}\text { Transporte (entrega) } \\
\text { Manuseio no CD: variáveis } \\
\text { ICMS }\end{array}$ & $\begin{array}{l}\text { Rota de entrega do item } \\
\text { pedido }\end{array}$ \\
\hline
\end{tabular}

Tabela 2.2. Hierarquia de decisão para o problema da inter-relação Logística-ICMS

Portanto, pode-se tratar a questão da Logística integrada ao ICMS em diversos níveis de decisão. No caso desta tese, escolheu-se trabalhar com o nível estratégico, pois os níveis tático e operacional têm graus de liberdade restritos e podem ser adequadamente tratados com modelos de decisão menos sofisticados.

No nível estratégico, o problema de localizar os depósitos ou CD’s significa projetar a rede logística que vai se incumbir da distribuição física dos produtos. O projeto da rede física de distribuição vai então definir onde instalar as diversas unidades, quantas devem ser e qual a dimensão de cada uma delas (Martos, 2000, Cap.3). Naturalmente, um trabalho dessa natureza exige a manipulação de uma grande 
quantidade de parâmetros e informações. A complexidade dos tradeoffs e o porte do problema justificam o uso de modelos matemáticos de otimização para auxiliar a análise e definição da rede mais adequada (Geoffrion, 1976a; Geoffrion; Powers, 1995; Love; Morris; Wesolowsky, 1988, Cap. 8; Ballou, 1999, Cap. 13 e 14). A seguir descreveremos alguns modelos utilizados na literatura de localização, com concentração nos modelos de Programação Linear Inteira Mista, utilizada na modelagem da tese.

\subsection{Projeto de cadeias de distribuição (modelos de localização)}

A teoria de localização se presta de maneira bastante adequada para tratar o problema de localizar depósitos de produtos acabados ou centros de distribuição, sendo ela um dos campos mais antigos da aplicação de modelagem matemática à administração de empresas. Iniciado com o trabalho do economista alemão Alfred Weber na primeira década do Século XX (Love; Morris; Wesolowsky, 1988), o campo se desenvolveu prolificamente, contemplando modelos e métodos variados. Para uma breve revisão da literatura associada, pode-se consultar Brandeau; Chiu (1989) ou Martos (2000, Cap. 3).

O problema estratégico de localização de centros de distribuição é um dos mais comuns e complexos, pois duas ou mais instalações devem ser localizadas simultaneamente (Ballou, 1999, Cap. 13). É um problema comum na distribuição física de produtos de consumo não duráveis, pois apenas empresas pequenas possuem uma única instalação no seu sistema logístico. É complexo porque as diversas unidades não podem ser tratadas como economicamente independentes, pois existem diversos tradeoffs logísticos importantes, como custos de transporte, armazenagem e estoques, além de considerações de nível de serviço.

Este último ponto é importante, pois é comum haver grandes distâncias entre as cidades brasileiras (chegando a alguns milhares de quilômetros), fato que leva as empresas a utilizarem depósitos locais não apenas quando há ganhos em função de 
diminuição de custos de transporte (fazendo transferências com menor custo unitário do que entregas aos clientes), mas também para garantir um prazo de entrega satisfatório (avaliado, neste trabalho, em função da distância máxima que um cliente pode ficar da unidade que o atende).

A Figura 2.4 descreve esquematicamente o problema mais geral de projeto de rede, mostrando todo o canal de distribuição física:

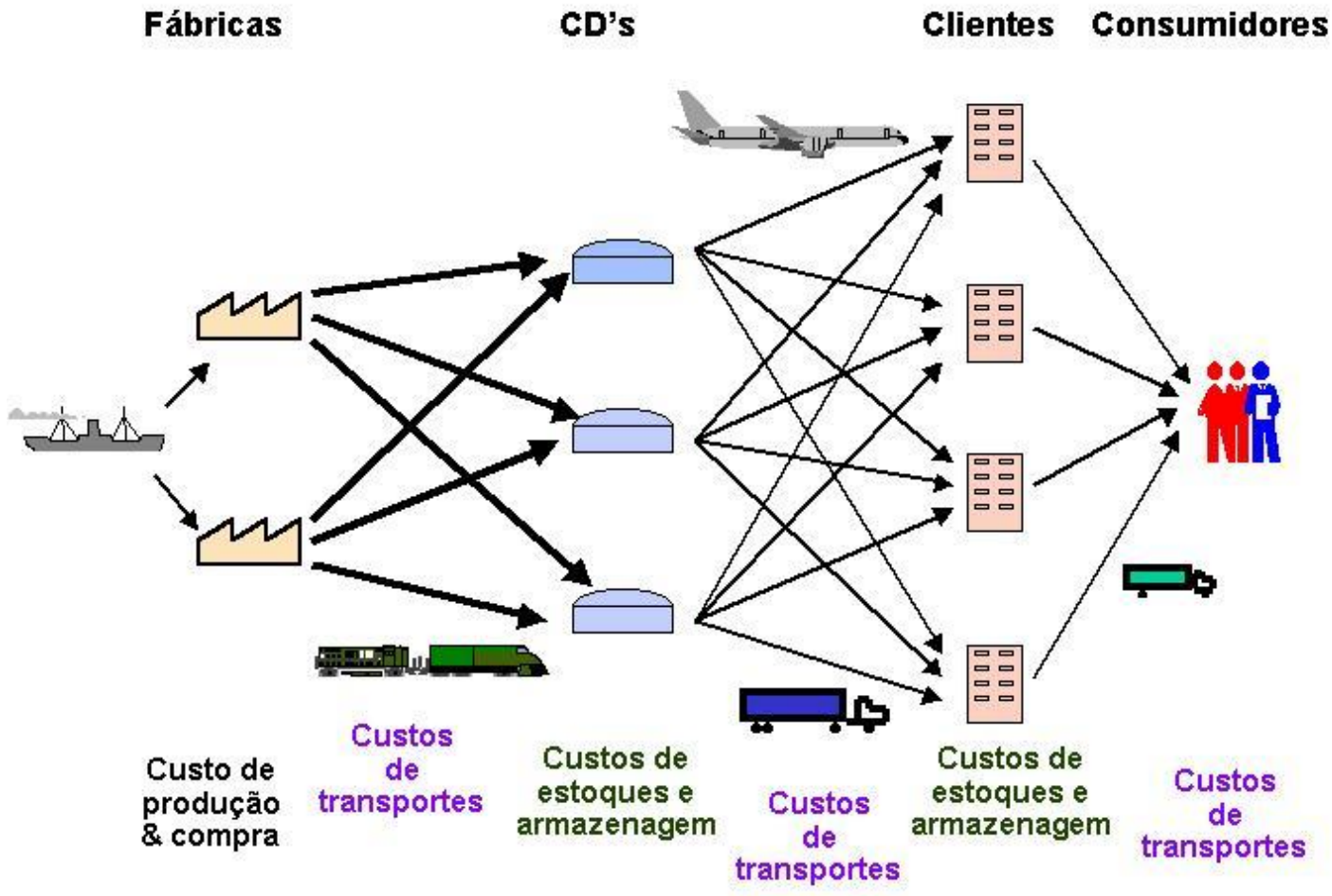

Figura 2.4. Exemplo de rede de distribuição.

Conforme Ballou (1999, Cap. 13), podemos classificar métodos de resolução do problema de localização conforme cinco critérios:

- Força propulsora: o fator mais crítico terá maior influência na modelagem; no caso da localização de fábricas e depósitos, os fatores econômicos são os mais importantes; para serviços de emergência (ambulâncias, bombeiros), a acessibilidade é prioritária. 
- Número de instalações: podemos ter problemas que envolvam determinar a localização de uma única instalação ou selecionar múltiplas instalações simultaneamente.

- Escolhas discretas: nos métodos contínuos, explora-se um espaço contínuo para selecionar a melhor localização das instalações (ou seja, uma fábrica ou depósito pode ser posicionado em qualquer lugar de um plano contínuo, podendo ser, por exemplo, o meio de um lago ou o topo de uma montanha); nos métodos discretos, pode-se escolher de uma lista de sítios possíveis préselecionados por suas características potenciais e são os mais usados na prática para a localização de instalações múltiplas.

- Agregação de mercados: pode-se ter diferentes graus de agregação de itens e mercados, conforme o nível do problema; por exemplo, para determinar em quais municípios deve-se instalar fábricas ou depósitos, pode-se agregar a demanda dos clientes individuais (estabelecimentos comerciais) em municípios, micro-regiões ou mesorregiões; na seleção final do sítio do depósito na cidade, o nível de agregação deve ser pequeno para possibilitar a micro-localização.

- Horizonte de tempo: métodos que abordam apenas um período de tempo (por exemplo, fluxos anuais) são chamados de estáticos; caso tratem múltiplos períodos de tempo, são chamados de dinâmicos.

Além disso, Brandeau; Chiu (1989) também classificam os métodos conforme a técnica empregada para a solução dos modelos. Conforme Martos (2000, Cap.3), podemos então agrupar os métodos em:

- Otimizadores ou exatos: avaliam todas as alternativas e selecionam a melhor; é possível demonstrar matematicamente que a solução encontrada é ótima nas condições definidas pela modelagem.

- Heurísticos: ao invés de garantir a solução ótima, utiliza-se uma heurística que reduz o processo de busca de soluções para encontrar uma solução satisfatória do problema, economizando-se o tempo de processamento.

- Simulação: monta-se um modelo, muitas vezes estocástico, que apresente as principais características da rede em estudo, podendo-se então avaliar o 
desempenho de alternativas propostas; essas alternativas podem então ser replicadas diversas vezes, gerando estatísticas utilizadas na seleção final.

Para o projeto de redes de distribuição física no nível estratégico, Geoffrion (1976) e Geoffrion; Powers (1995) defendem enfaticamente o uso de métodos otimizadores, pois: são tecnicamente viáveis (disponibilidade de algoritmos, hardware e software); as empresas tem dados disponíveis para esse tipo de estudos (sistemas de bancos de dados automatizados são a regra e não mais a exceção); conseguem avaliar simultaneamente todos os complexos tradeoffs logísticos em problemas de grande porte.

Há grande quantidade de ferramentas prontas de localização disponíveis no mercado (Ballou; Masters, 1993; 1999), sendo que a grande maioria (90\% na pesquisa de 1999) utiliza Programação Linear ou Programação Linear Inteira Mista. Por isso, Geoffrion; Powers (1995) demonstram surpresa ao ver a popularidade que ferramentas baseadas em heurísticas ainda têm no mercado e creditam esta aceitação ao fato delas utilizarem interfaces gráficas. Conforme Ballou; Masters (1999), isto pode ser explicado pelo fato de estudos de localização ainda serem mais arte que ciência, pois não é possível colocar todos fatores possíveis em um modelo matemático, por melhor que seja o método de solução empregado.

Ballou (1999, Cap. 13) considera a Programação Linear Inteira Mista (PLIM) como o método exato mais promissor para problemas de localização de múltiplas facilidades, pois, ao contrário da maioria dos outros métodos, consegue trabalhar com custos fixos de maneira ótima. Além disso, a PLIM também consegue modelar economias de escala em instalações (Bueno Neto, 1988) pela aproximação de custos não-lineares côncavos por uma poligonal de segmentos lineares (Winston, 1995, Cap. 9). Um exemplo de custos poligonais aplicados em problemas de localização está detalhada em Love; Morris; Wesolowsky, (1988, p. 194).

A partir do trabalho de Geoffrion; Graves (1974), Ballou (1999, Cap.13) descreve o problema de projeto de distribuição física paradigmático de PLIM na literatura: 
"Encontre o número, a dimensão e os sítios de armazéns em uma rede logística que minimizarão os custos fixos e variáveis que movimentarão todas as mercadorias através da rede selecionada sujeito às seguinte condições:

1. O suprimento disponível da fábrica não pode ser excedido para cada mercadoria.

2. A demanda de todas as mercadorias deve ser satisfeita.

3. O processamento de cada armazém não pode exceder sua capacidade.

4. Um processamento mínimo de um armazém deve ser conseguido antes que ele possa ser aberto.

5. Todas as mercadorias para o mesmo cliente devem ser atendidas pelo mesmo armazém."

O modelo matemático de Geoffrion e Graves (1974) associado é:

Índices:

$i$... Fábricas ou fontes de fornecimento

$j$... Locais candidatos a CD's

$k$... Mercados (zonas de demanda)

$p$... Produtos (agregados em classes, pode ser mais de um por fábrica)

Parâmetros:

$\operatorname{DemM}_{k p} \ldots$ Demanda do produto $p$ no mercado $k$ (unid./ano).

$C a p D_{j} \ldots$ Capacidade (volume máximo) do depósito $j$ (unid./ano).

$\operatorname{Min}_{j} \ldots$ Volume mínimo (fluxo) no depósito $j$ (unid./ano).

$C_{a p} F_{i p} \ldots$ Capacidade da fábrica $i$ para produto $p$ (unid./ano).

CusD $D_{i j k p}$... Custo unitário (variável) de produzir e transportar o produto $p$ da fábrica $i$ por intermédio do depósito $j$ até o mercado $k$ (\$/unid.).

$C u s B_{j} \ldots$ Custo unitário (variável) de manuseio no $\mathrm{CD} j$ (\$/unid.).

Fix $D_{j} \ldots$ Custo fixo do depósito $j(\$)$. 
Variáveis:

$D_{\operatorname{str}} D_{i j k p} \quad \ldots$ Quantidade distribuída de produto $p$ transportada da fábrica $i$ por intermédio do depósito $j$ para o mercado $k$ (unid.).

$Y_{j k} \ldots$ Assume valor 1 caso um depósito no local $j$ atender o mercado $k, 0$ em caso contrário (variável binária).

$Z_{j} \ldots$ Assume valor 1 caso um depósito estiver operando no local candidato $j, 0 \mathrm{em}$ caso contrário (variável binária).

$C T$... Custo total de operação (\$).

Restrições/Equações:

Função de mérito, que é minimizar o custo total CT.

$$
\min C T=\sum_{i} \sum_{j} \sum_{k} \sum_{p} C u s D_{i j k p} \operatorname{DstrD}_{i j k p}+\sum_{j}\left(F i x D_{j} Z_{j}+C u s B_{j} \sum_{k} \sum_{p} \operatorname{DemM}_{k p} Y_{j k}\right)
$$

Restrição de atendimento da demanda de produto $p$ no mercado $k$.

$$
\operatorname{DemM}_{k p} Y_{j k}=\sum_{i} D s t r D_{i j k p} \quad \forall j, \forall k, \forall p .
$$

Restrição de capacidade de produção da classe de produtos $p$ na fábrica $i$.

$$
\sum_{j} \sum_{k} \operatorname{DstrD}_{i j k p} \leq \mathrm{CapF}_{i p} \quad \forall i, \forall p .
$$

Restrições de volume mínimo e de capacidade máxima de operação do depósito $j$.

$$
\operatorname{MinD}_{j} Z_{j} \leq \sum_{k} \sum_{p} \operatorname{DemM}_{k p} Y_{j k} \leq \operatorname{CapD}_{j} Z_{j} \quad \forall j .
$$

Relação garantindo que apenas um depósito $j$ atenda um mercado $k$.

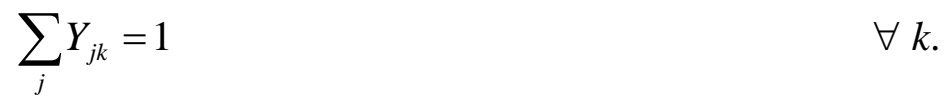

Restrições lineares de configuração usando as variáveis $Y_{j k}$ e/ou $Z_{j}$.

Não negatividade.:

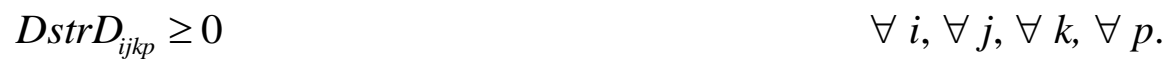

Variáveis binárias: 


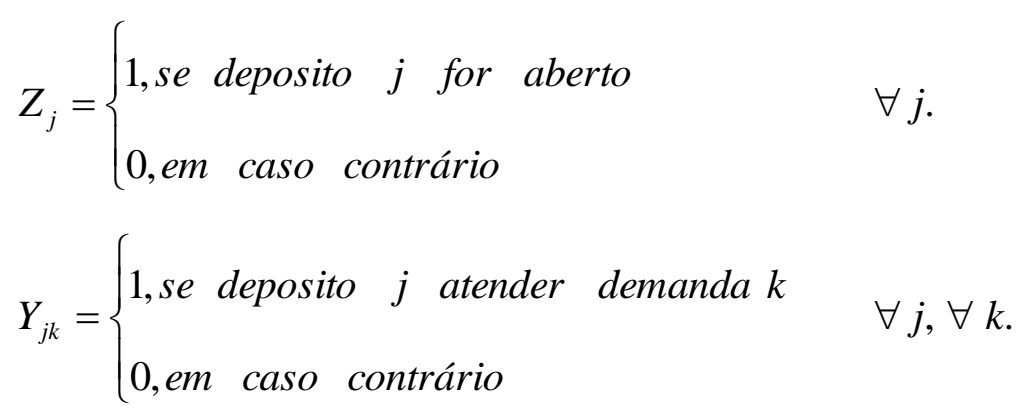

As restrições de configuração (2.6) servem como um artifício que obriga a seleção de, no máximo, uma única versão (capacidade, ou seja, custo fixo) para um CD que é aberto em um determinado local. Além disso, no problema original, foi necessário introduzir restrições de nível de serviço para garantir um tempo máximo de atendimento. Por exemplo, depósitos inaceitavelmente distantes de um determinado cliente $k^{+}$tinham o custo designado ao seu $Y_{j k+}$ penalizado significativamente.

O modelo de Geoffrion e Graves é bastante adequado para tratar os problemas de projeto estratégico de redes de distribuição física, sendo utilizado em certos sistemas (softwares) de localização de instalações (Geoffrion; Powers, 1995). Ele poderia ser a base daquele utilizado nesta tese. Entretanto, ele tem algumas características que precisam ser melhor observadas para ser empregado no problema de inter-relação Logística-ICMS.

Primeiramente, ele tem uma restrição muito forte para o caso em análise: cada cliente (mercado $k$ ) é atendido a partir de um único centro de distribuição $j$. Na prática, conforme a conveniência e o custo total, pode ser conveniente abastecer o mesmo mercado a partir de CD's diferentes: por exemplo, um cliente indiferente ao crédito de ICMS (sonegador) pode receber suas mercadorias a partir de um CD localizado de maneira mais conveniente (possivelmente fora do Estado onde o cliente se encontra); para um cliente que deseja o crédito, é importante receber de uma instalação no mesmo Estado. Portanto, será necessário relaxar o conjunto de restrições (2.5) e (2.9). 
Este relaxamento permitirá alterar a estrutura de restrições, pois pode-se agora tratar os fluxos fábrica $i$ depósito $j$ como independentes dos fluxos depósito $j$ clientes $k$. Ou seja, a estrutura do problema relaxado (com exceção das restrições de volume mínimo e máximo e de configuração), que fica parecida com um problema clássico de transporte (dois estágios), é transformada na estrutura de um problema de transbordo (três estágios).

Além disso, não há necessidade de restrições de volume mínimo: no problema original, elas estavam associadas ao fato de se empregar o modal ferroviário para as transferências fábrica-depósito. Por isso, exigia-se um volume mínimo de 8 vagões em cada lote de transporte para garantir ganhos de escala (Geoffrion, 1976). Como, no caso da tese, utiliza-se o modal rodoviário, tal restrição não se aplica. Um CD será aberto se a economia resultante de transporte justificar o custo fixo adicional ou se houver exigência por nível de serviço.

Como aspecto complementar, o modelo de Geoffrion e Graves não incorpora de forma direta custos de manutenção de estoques; assume-se implicitamente que os custos de transporte e manuseio são preponderantes. Essa aproximação funciona melhor para casos de modais de transporte velozes, confiáveis e com tamanhos de lote pequenos (como aéreo e rodoviário), mercadorias de alto giro, como aquelas encontradas atualmente em estabelecimentos de auto-serviço, e produtos com menor valor por tonelada.

Assim, será empregado um modelo relaxado que é um problema de transbordo multiproduto com custos fixos, adaptado para as condições particulares do problema. Ele será detalhado no Capítulo 3. 


\subsection{A questão tributária e o ICMS}

Neste item trata-se dos aspectos tributários em geral e do ICMS em particular. Inicialmente vai-se colocar a questão tributária de forma legal, classificando-se os diversos tipos de tributo e os princípios que os norteiam. A seguir, um histórico do ICMS é apresentado, sendo que formas alternativas de cálculo são apresentadas de forma resumida. Finalmente, seus efeitos serão objeto de discussão.

\subsubsection{Aspectos legais da questão tributária nacional}

Souza (1975) apud Ribeiro (1999, p. 26) define Direito Tributário como “o direito que regula a cobrança e fiscalização de tributos", sendo “...um ramo especializado do direito financeiro que se ocupa da atuação, isto é, do funcionamento, dos institutos jurídicos financeiros relativos à receita pública". A idéia é que o Estado exerce atividades econômicas que não podem ser expostas ao insucesso, de forma que o mesmo deve garantir receita para custeá-las. O Estado pode fazê-lo de forma coercitiva, instituindo os tributos necessários para sua provisão.

Latorraca (1975, p.25) apud Ribeiro (1999, p.28) define tributo como "receita derivada (proveniente do patrimônio dos particulares) que o Estado arrecada mediante o emprego de sua soberania, nos termos fixados em lei”.

Seguindo Cassone (1995, p.334), Ribeiro destaca quatro elementos da relação jurídica tributária:

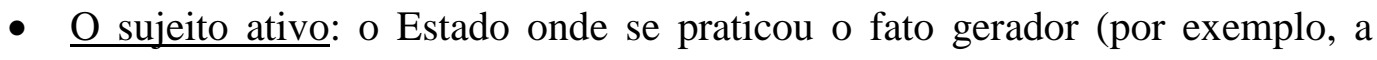
venda de uma mercadoria por uma pessoa jurídica a um consumidor).

- O sujeito passivo: o contribuinte, quem se obriga a realizar o mandamento da relação jurídica (por exemplo, a empresa vendedora que fica "devendo" o valor do tributo equivalente ao Estado).

- A relação jurídica: é aquela que se estabeleceu entre o contribuinte e o Estado devido à ocorrência do fato gerador. 
- Objeto: é o tributo associado ao fato gerador.

O direito tributário no país é fundamentado nos artigos 145 a 162 da Constituição da República Federativa do Brasil (1988) e em outras leis correlatas, as quais compõem o Sistema Tributário Nacional, que é “...o conjunto de princípios gerais, das limitações do poder de tributar, de atribuição da competência tributária privativa (discriminação de rendas) entre União, Estados, Distrito Federal e Municípios, e da repartição das receitas tributárias...” (Cassone, 1995, p. 94, apud Ribeiro, 1999, p.29).

Segundo Martins (1989), apud Ribeiro (1999, p. 29-30), o Sistema Tributário Nacional incorpora nove princípios fundamentais, expressos nos artigos 150 a 152 da Constituição, a saber:

1. Princípio da legalidade: não "exigir ou aumentar tributo sem lei que o estabeleça".

2. Princípio da igualdade: veda "instituir tratamento desigual entre contribuintes que se encontrem em situação equivalente...".

3. Princípio da irretroatividade: veda "cobrar tributos em relação a fatos geradores ocorridos antes do início da vigência da lei que os houver instituído ou aumentado;",

4. Princípio da anterioridade: veda "cobrar tributos no mesmo exercício financeiro em que haja sido publicada a lei que os instituiu ou aumentou;"

5. Princípio da vedação de confisco: veta "utilizar tributo com efeito de confisco;"

6. Princípio da vedação à limitação ao tráfego de pessoas ou bens: veda “estabelecer limitações ao tráfego de pessoas ou bens, por meio de tributos interestaduais ou intermunicipais, ressalvada a cobrança de pedágio pela utilização de vias conservadas pelo Poder Público”.

7. Princípio da imunidade: visa resguardar “...o equilíbrio federativo, a liberdade de associação, do livre pensamento, a política, a religiosa, a de expressão, a expansão da cultura, o desenvolvimento econômico, etc...", pois é "vedado à União, aos Estados, ao Distrito Federal e aos Municípios... instituir impostos 
sobre ... patrimônio, renda ou serviços uns dos outros, templos, partidos políticos, ....entidades sindicais..., instituições de educação e assistência social, sem fins lucrativos..."

8. Princípio da uniformidade de tributos federais: veda à União "instituir tributo que não seja uniforme em todo o território nacional ou que implique distinção ou preferência em relação a Estado, ao Distrito Federal ou a Município, em detrimento de outro, admitida a concessão de incentivos fiscais destinados a promover o equilíbrio do desenvolvimento sócio-econômico entre as diferentes regiões do país."

9. Princípio da uniformidade dos tributos Estaduais, do Distrito Federal e dos Municípios: veda aos mesmos “...estabelecer diferença tributária entre bens e serviços, de qualquer natureza, em razão de sua procedência ou destino".

Qualquer tributo criado por qualquer das três esferas do poder executivo deve respeitar os princípios acima enunciados. Para a problemática do ICMS e Logística, os princípios da igualdade, da vedação à limitação de tráfego de bens e da uniformidade são mais importantes.

Cassone (1995, p. 122) apud Ribeiro (1999, p. 31-33) classifica os diversos tributos em:

- Impostos: tributos exigíveis independentemente de qualquer atividade estatal específica relativa ao contribuinte; não têm destinação específica.

- Taxas: tributos exigíveis em razão do exercício do poder de polícia ou pela utilização de serviços públicos específicos e divisíveis; destina-se a custear o serviço público relativo à taxa.

- Contribuições de melhoria: tributos exigíveis em decorrência de obra pública; destina-se a custear parcialmente a relativa obra beneficiada.

- Contribuições especiais: tributos exigíveis, às vezes de contribuintes específicos, como empresas ou servidores públicos, para custear atividades de cunho social, como a Securidade Social, o salário-educação, a previdência dos servidores, etc. 
- Empréstimos compulsórios: tributos exigíveis pela União para atender despesas extraordinárias (calamidade pública, guerra externa) ou investimento público urgente e de relevante interesse.

Referenciando o artigo 16 do Código Tributário Nacional, Cassone (1995, p.124) apud Ribeiro (1999, p. 33) cita que "imposto é o tributo cuja obrigação tem por fato gerador uma situação independente de qualquer atividade estatal específica, relativa ao contribuinte". Assim, o contribuinte recolhe impostos sem receber um benefício específico em troca.

$\mathrm{O}$ fato gerador comentado acima deve necessariamente estar associado ao contribuinte. Cada imposto tem fato gerador específico. Por exemplo, a posse de um caminhão é o fato gerador do Imposto sobre a Propriedade de Veículos Automotivos - IPVA; a operação de venda de um televisor pela indústria para uma loja de departamentos é fato gerador tanto do Imposto sobre Produtos Industrializados (IPI) como do ICMS.

Estes dois últimos impostos (IPI e ICMS) apresentam características específicas ligadas às suas formas de tributação (artigos 153 e 155 da Constituição brasileira):

- Seletividade: as alíquotas podem variar conforme a essencialidade de cada produto, mercadoria ou serviços; assim, gêneros da cesta básica são isentos de IPI ou tem alíquotas menores de ICMS; bens considerados supérfluos, como bebidas alcoólicas e perfumes, têm alíquotas elevadas (por exemplo, $40 \%$ de IPI e $25 \%$ de ICMS).

- Não-cumulatividade: é considerado princípio tributário (Martins, 1989, apud Ribeiro, 1999, p. 34); cada estágio do fluxo comercial recolhe apenas o imposto calculado sobre sua agregação de valor (como já visto no exemplo do Capítulo 1), ou seja, compensa-se o que for devido em cada operação com o montante cobrado de operações anteriores. É a questão do crédito e débito dos valores, que serve tanto para o IPI como o ICMS. 
Cumpre comentar que a seletividade não fere o princípio da universalidade para o IPI e o ICMS, pois as alíquotas são as mesmas em todo território nacional (caso do IPI, tributo federal) ou no Estado ou Distrito Federal (caso do ICMS, tributo estadual) onde ocorreu o fato gerador do imposto (Ribeiro, 1999, p.34).

Os impostos podem ser categorizados também em diretos e indiretos. Conforme Souza (1975, p.170) apud Ribeiro (1999, p. 35), impostos diretos são aqueles suportados em definitivo pelo contribuinte, sendo o fato gerador uma situação permanente (como a propriedade) ou continuada (como a renda de um indivíduo). O Imposto de Renda (IR) é um exemplo de imposto direto. Os impostos indiretos podem ser transferidos por um contribuinte para outra pessoa à jusante na cadeia comercial, a qual os transferirá ou os suportará em definitivo. Seu fato gerador é uma situação momentânea ou isolada no tempo, como transações de compra e venda de mercadorias ou o seu consumo. Assim, IPI e ICMS são impostos indiretos.

Os impostos podem ser classificados em (Souza, 1975, p.170):

- Fixos: o valor é fixado, independentemente do valor da matéria tributável. Um exemplo é o selo-lacre dos cigarros, que tem valor fixo, não importando o preço final dos mesmos.

- Proporcionais: a forma de cálculo é a aplicação de uma proporção constante sobre o valor da matéria tributada. É o caso das alíquotas de IPI e ICMS.

- Progressivos: a forma de cálculo varia de acordo com o valor da matéria tributável, podendo ser simples (alíquota aplicada diretamente ao valor) ou graduada (alíquotas progressivas, como no cálculo de IR).

Conforme a Constituição Federal Brasileira (artigos 153 a 156), compete à União instituir impostos sobre importação, exportação, rendas e proventos de qualquer natureza, produtos industrializados, operações financeiras, propriedade rural, grandes fortunas e outros não previstos (por lei complementar, desde que não-cumulativos e não tenham fato gerador ou base de cálculo já previstos na Carta Magna); aos Estados e ao Distrito Federal, os impostos de transmissão causa mortis e doação, operações relativas à circulação de mercadorias e prestação de serviços de certos 
serviços, e de propriedade de veículos automotores; e aos Municípios, impostos sobre a propriedade territorial urbana, transmissão inter vivos e serviços de qualquer natureza (desde que não seja de competência dos Estados ou Distrito Federal).

\subsubsection{Aspectos gerais do ICMS}

O Imposto sobre Operações relativas à Circulação de Mercadorias e sobre Prestações de Serviços de Transporte Interestadual e Intermunicipal e de Comunicação (ICMS) é um imposto indireto, de cálculo proporcional que segue os princípios da seletividade e da não-cumulatividade, além, evidentemente, os outros nove princípios gerais da Constituição Federal Brasileira. A Carta Magna (artigo 155, pela redação da Emenda Constitucional no. 3 de 17 de Março de 1993) também reza que cabe ao Senado estabelecer as alíquotas aplicáveis às operações interestaduais, bem como ele poderá definir alíquotas mínimas e máximas, no caso de conflitos que envolvam interesse dos Estados.

O ICMS é tributo que incide sobre o consumo e tem longa história, que remonta ao Imposto sobre Vendas Mercantis - IVM, instituído pela lei federal $n^{\circ} 4.625$ de 31 de Dezembro de 1922, de competência tributária atribuída aos Estados membros dos então Estados Unidos do Brasil (Rosa, 2000). O país foi um dos primeiros a tributar o consumo, pois foi somente durante a Primeira Guerra Mundial que surgiram tais impostos, o chiffre d'affaires na França e o Umsatzsteur na Alemanha. A prática até então era tributar quase exclusivamente o patrimônio.

O IVM incidia diretamente sobre o valor de venda na alíquota de 0,3\%. A Constituição de 1934 estendeu a incidência do IVM sobre operações de consignações, que se tornou o Imposto sobre Vendas e Consignações - IVC, e sobreviveu até 1965 (Rosa, 2000).

A principal característica do velho IVC era que o mesmo incidia "em cascata" por toda a cadeia comercial, ou seja, era cumulativo. Constatou-se que isto gerava efeitos negativos para o sistema produtivo, pois mercadorias com ciclo de produção ou 
circulação econômica mais longa até o consumo teriam taxação maior. Esta situação incentivava a verticalização das empresas de bens de consumo, levadas a realizar todas as etapas produtivas no mesmo estabelecimento (Rosa, 2000).

Outro efeito foi a perda de competitividade das empresas de menor porte, que não tinham condições financeiras para a industrialização plena de suas mercadorias. Elas passaram a ficar em situação tributária desvantajosa, com seu produto final encarecido pelas sucessivas aplicações do IVC.

O IVC, portanto, carecia da neutralidade, pois acabava por privilegiar empresas de maior porte em detrimento das menores. Por esse motivo (conforme Rosa, 2000), em 1965, a Reforma Constitucional no. 18 adotou na tributação sobre o consumo o princípio da não-cumulatividade e instituiu o Imposto de Circulação de Mercadorias - ICM. O ICM era apurado pela confrontação de créditos e débitos: créditos relativos a entrada de mercadorias no estabelecimento do contribuinte e débitos na sua saída. Foi uma cópia alterada do modelo francês de 1954, que implantou a taxe sur la valeur ajountée, tributo sobre o valor adicionado, resultado de estudos iniciados em 1936 e que levaram à observância do princípio da não-cumulatividade naquele país.

A Constituição de 1988 manteve esse princípio ao criar o ICMS como sucessor do ICM e também incorporou ao tributo a incidência sobre serviços de transporte e comunicações, assim como sobre energia elétrica, combustíveis, lubrificantes e minerais, até então alvo da União (Rosa, 2000).

De todos os tributos, o ICMS é um dos que têm maior impacto nas operações logísticas nacionais, pois, sendo de esfera estadual, sua uniformidade é garantida apenas dentro dos limites do Estado onde ocorre fato gerador. Impostos federais como IPI e Imposto de Importação, que têm uniformidade nacional, não afetam tanto a logística entre Estados (com exceção da questão da legislação associada à SUFRAMA - a Zona Franca de Manaus); eles podem, entretanto, afetar a competitividade internacional de produtos brasileiros. 
Não vale a pena repetir a forma de cálculo do ICMS, pois ela foi tratada com detalhe na Introdução, onde se pode perceber a questão da não-cumulatividade. Entretanto, deve-se comentar que há um efeito do tempo na compensação do ICMS para uma empresa: tudo depende da quando ocorrem a entrada e a saída da mercadoria. No caso de uma indústria que utiliza depósitos regionais (como os exemplos do Capítulo 1), pode haver ganhos ou perdas financeiras conforme a situação de entradas e saídas no armazém (se ocorrerem no mesmo mês do exercício ou não), que serão mais ou menos significativas conforme aumenta ou diminui a taxa de oportunidade. Como a análise feita nesta tese é econômica, pode-se adotar como hipótese simplificadora que entradas e saídas ocorrem no mesmo mês sem perda de generalidade das conclusões. Para um exemplo detalhado, pode-se consultar Ribeiro (1999, p. 10-12).

Como foi visto no Capítulo 1, operações interestaduais têm alíquotas significativamente inferiores às alíquotas internas aos Estados, o que possibilita à indústria utilizar em seu favor o "turismo do ICMS" caso os clientes que atende não se interessem pelo crédito do ICMS. Como a sonegação é considerada significativa e, portanto, tais clientes são indiferentes ao crédito do imposto, há potencial para o "turismo".

É importante notar que quem cometeria sonegação é o estabelecimento cliente e não a indústria. Abastecer clientes de uma filial localizada em outro Estado (que foi aberta ou não para a finalidade de "turismo" do ICMS) é uma possibilidade operacional da indústria, que se vale desse aspecto da legislação para reduzir sua tributação. Há uma preocupação constante nas empresas para diminuir sua carga de impostos, sendo esta uma área de domínio do chamado planejamento tributário. O "turismo" seria então um ato legal de reduzir o montante de tributo devido, denominado de elisão fiscal (Cassone, 1995, p. 93).

Uma maneira de coibir ou evitar a perda de receita devida à sonegação e, desta forma, tornar o "turismo" de mercadorias uma prática desnecessária e custosa, é a prática da substituição tributária pelos governos estaduais. A substituição tributária é um artifício previsto na Constituição (artigo 155, parag. 2) e que antecipa o fato 
gerador para um substituto tributário a montante na cadeia de valor, que então faz o papel do contribuinte do final da cadeia.

Um exemplo de substituição tributária é o que ocorre na venda de combustíveis fósseis, como gasolina e óleo diesel. Como o último elo da cadeia é composto por milhares de varejistas dispersos por área muito ampla, o ICMS final é recolhido pela própria indústria (no caso, a Petrobrás). Ou seja, a Petrobrás não recolhe o ICMS calculado somente na sua agregação de valor; sua base de cálculo é o preço médio do varejo. Assim, mesmo que haja sonegação no varejo (e quem pede nota fiscal no posto de abastecimento de combustível?), o tributo já foi recolhido pela indústria.

Naturalmente a fixação do preço final pelos poderes executivos dos Estados que utilizam a substituição tributária é sempre um ponto de polêmica, pois preços são definidos pelo mercado e não por decreto. Assim, a experiência dos últimos anos levou a algumas revisões no procedimento da substituição tributária. Atualmente, caso o preço final real seja superior ao estipulado pelo governo, não há necessidade do varejista recolher a diferença, o Estado assume a perda de receita; caso o varejista tenha praticado preço inferior ao definido pela substituição, ele terá um crédito equivalente à diferença.

Poderia a substituição tributária ser uma alternativa capaz de eliminar a sonegação e, portanto, o "turismo" de mercadorias, na economia em geral? A resposta é não, pois ela só é uma opção prática quando a cadeia de valor tem algum estágio onde acontece o seu afunilamento ou concentração em algumas poucas empresas. $\mathrm{O}$ caso dos combustíveis é emblemático: a estrutura da cadeia de valor começava com uma única empresa (Petrobrás), que detém o monopólio do refino de combustíveis fósseis; a partir daí, a cadeia vai se ramificando nos distribuidores de combustíveis e destes nos postos revendedores (varejo). Ou seja, é uma estrutura arborescente, onde é possível tributar-se uma única empresa (Petrobrás) pois todo o fluxo passa necessariamente por ela, simplificando enormemente a fiscalização. Outro exemplo é a indústria de óleo de cozinha: em Goiás, a produção de grãos para as indústrias de moagem de soja, milho, etc é dispersa pelo interior do Estado, impossibilitando a 
fiscalização efetiva. Da mesma forma, a outra ponta da cadeia do óleo comestível é composta por uma miríade quase infinita de estabelecimentos varejistas. Porém, o fluxo de mercadorias se concentra no meio da cadeia: há relativamente poucas indústrias de óleo comestível, todas elas de grande porte (Manual do ICMS do Estado de Goiás, 2002). Assim, novamente, a indústria é o substituto tributário.

Ora, muitas cadeias de valor não têm essa característica de concentração em um estágio do fluxo. Por exemplo, a indústria de biscoitos e bolachas é bastante pulverizada, com as três marcas principais tendo participação de somente $23,7 \%$ do mercado nacional. Há grande número de marcas regionais e locais competindo com as de alcance nacional. O mesmo ocorre com certos produtos de limpeza, macarrão, etc. Logo, a substituição tributária não consegue resolver o problema de forma geral. Além disso, a substituição tributária é competência dos governos estaduais, criando diferenças nas listas de produtos em função de diferentes estruturas de cadeias de suprimentos nos Estados. Por exemplo, o óleo de cozinha é objeto de substituição tributária em Goiás mas não em Santa Catarina.

O recolhimento de ICMS em Estados com elevado índice de industrialização (como os do Sudeste) é feito em boa parte pela indústria e grandes cadeias atacadistas e varejistas, estimando-se que haja elevado grau de sonegação no pequeno varejo. Neste último é comum encontrar-se produtos com preços equivalentes ou mesmo inferiores aos das grandes redes de varejo; como as pequenas empresas pagam preços maiores que as grandes redes, este é um bom indício de sonegação. Para certos Estados pouco industrializados do Nordeste e Centro-Oeste, porém, o ICMS provindo do varejo é fonte essencial de receita, pois basicamente importam manufaturados. Assim, conforme sua necessidade financeira, eles agem preventivamente, barrando caminhões nos postos de fronteira e somente liberando os mesmos após o recolhimento da diferença entre as alíquotas interestadual e interna do ICMS daquela carga. Isto ocasiona todo tipo de transtorno, tanto para as transportadoras (muitas não sabem que sua carga está na "lista negra" daquele período em particular) como para os clientes (por exemplo, para chegar ao Rio 
Grande do Norte, proveniente do Sudeste, é necessário atravessar meia dúzia de fronteiras de Estados nordestinos e respectivos postos fiscais).

Pode-se então perceber que a solução para o problema do "turismo" do ICMS não é simples. A idéia de se empregar um Imposto sobre Valor Agregado - IVA (como nos países desenvolvidos) no final da cadeia esbarra com a dificuldade prática de como se fiscalizar milhões de estabelecimentos no Brasil. Uma outra idéia seria recolher-se totalmente apenas no início da cadeia (manufatura), sendo o recolhimento dividido entre os Estados conforme seu consumo. Para isso, seria preciso que a União administrasse o repasse; pode-se perceber a dificuldade de aprovar um esquema desses. A adoção de uma alíquota unificada pode ser viável, mas com certeza não é das mais fáceis. No final da tese voltaremos a esse assunto, mas pode-se concluir que as empresas brasileiras terão de conviver com essa situação ainda por alguns anos.

\subsection{Trabalhos prévios de Logística e ICMS}

Conforme comentado no capítulo de Introdução, os livros-texto de Logística não mencionam a questão do ICMS e sua influência na Logística praticada pelas empresas, apesar do grande folclore que existe sobre o assunto. Apenas em um caso (Novaes, 1987) há menção da questão tributária; mesmo assim, ela é perfunctória (vide Capítulo 1).

Extensa busca nas diversas bases de dados resultou praticamente nula. Existem muitos trabalhos sobre um tema ou outro, mas nenhum sob o aspecto estratégico de projeto da rede de distribuição física considerando o ICMS como aspecto fundamental do gerenciamento da cadeia de suprimentos. Um exemplo típico é a dissertação de Ávila (1996), que aplicou uma heurística para tratar o problema de localização de centros de distribuição para uma indústria líder de produtos de consumo de massa, o mesmo tipo de problema e produto modelado nesta tese. Ele lembra a influência do ICMS na distribuição (Ávila, 1996, p. 70), mas considera o 
mesmo um "fato menor", tanto que o ICMS não entra como parâmetro no modelo matemático utilizado pelo autor (op.cit., p. 89).

Este tipo de "miopia" para a importância do ICMS na logística já foi encontrada pelo autor deste trabalho em mais de uma grande empresa; por coincidência ou não, todas eram grandes multinacionais, onde a preocupação com o nível de serviço (em termos de prazo de atendimento) oferecido aos clientes-chave situados nos grandes centros era muito grande.

Outro trabalho que gerou expectativa foi a tese de Coronado (2000), desenvolvida no Departamento de Contabilidade da Faculdade de Economia, Administração e Contabilidade da Universidade de São Paulo e que versa sobre formação de preços no setor atacadista/distribuidor com enfoque da Logística Integrada. Porém, o objetivo da tese era desenvolver um modelo de formação de preços onde, naturalmente, aspectos tributários eram considerados, mas efeitos gerais dos tradeoffs entre ICMS e Logística ficavam relegados ao segundo plano.

A exceção na busca foi a dissertação de mestrado escrita por Ribeiro (1999), que trata a distribuição física de mercadorias no contexto tributário nacional. Ribeiro realizou interessante revisão bibliográfica dos aspectos legais e tributários, listando todos os tributos conhecidos e observando quais teriam maior impacto na Logística. Em seguida, desenvolveu um modelo para auxiliar uma empresa a encontrar a rota de menor custo total (transporte mais ICMS) para atender um cliente. Ele aplica o modelo a um caso de uma indústria de perfumes.

O modelo desenvolvido por Ribeiro (1999, p. 119) é o clássico problema de caminho mínimo, sendo que ele resolve o mesmo implementando o algoritmo de Djiskstra para caminho mínimo (Ribeiro, 1999, p. 136; Winston, 1997, cap. 8). Ele penaliza os arcos do grafo com os custos de transporte e manuseio, assim como os tributos associados, que são tratados como custos. É importante notar que todos os custos do modelo empregado por Ribeiro são variáveis, o que evidencia a natureza táticooperacional da decisão modelada. Além disso, os custos componentes são pouco 
aderentes à realidade vigente, pois ele se baseou na tabela de fretes da NTC, notoriamente conhecida no mercado de transporte por ser bastante superior aos fretes efetivamente praticados. O objetivo de Ribeiro é mostrar uma metodologia para determinar a melhor rota (mínimo custo de transporte e recolhimento de ICMS) e não tirar conclusões gerais sobre a interrelação Logística-ICMS.

Ribeiro assume, entre outras hipóteses, que a estrutura logística já está montada. Como dito anteriormente, sob o aspecto de elisão fiscal e planejamento tributário, é melhor considerar a possibilidade de "empurrar" esse ganho na cadeia. Redes logísticas muitas vezes não são montadas com o intuito de reduzir custos logísticos e recolhimento de ICMS, o que leva as empresas a não terem seu canal operando de maneira otimizada. Caso a empresa pudesse escolher os sítios dos seus armazéns de forma ótima, ela restringiria os graus de liberdade para seus clientes escolherem a origem mais conveniente para as mercadorias.

Portanto, um tratamento mais geral para essa problemática seria desenvolver um estudo no nível estratégico, onde há a possibilidade de se abrir ou fechar centros de distribuição e projetar a rede de menor custo total. A partir desse modelo, pode-se então avaliar os tradeoffs entre ICMS e sonegação do ICMS. É o que está descrito no capítulo a seguir. 


\section{METODOLOGIA E MODELAGEM DO PROBLEMA}

Este capítulo define o problema de projeto de redes logísticas considerando-se o ICMS de modo detalhado e apresenta o modelo matemático de otimização desenvolvido para explorar suas soluções. A forma de cálculo e levantamento dos parâmetros é mostrada, assim como as hipóteses implícitas ao modelo.

\subsection{Definição do problema}

Para analisar a questão do ICMS e seu impacto na rede logística de uma empresa, montou-se um problema idealizado, mas com características suficientemente realistas (produtos, demandas, participação de mercado, custos) para permitir a generalização dos resultados obtidos.

O caso idealizado envolve a distribuição física conjunta de produtos provenientes de quatro fábricas distintas, localizadas em diferentes Regiões brasileiras, e que vendem produtos de marcas com alcance nacional. Como cada linha de produto de uma fábrica pode representar uma marca ou corporação diferente, mas a distribuição flui através do mesmo sistema, considera-se que a operação de entrega é coordenada por um operador logístico que administra os CD’s e os respectivos transportes. Os clientes são estabelecimentos comerciais (distribuidores, atacadistas, varejistas) espalhados pelo país.

A principal justificativa do sistema idealizado (quatro fábricas e operador logístico) é garantir volume e escopo geográfico de operação que permitam observar os ganhos de escala associados à distribuição física. $\mathrm{O}$ maior volume permite maior ganho potencial de consolidação de cargas nos CD’s (tanto na transferência de produtos das fábricas aos armazéns locais, como na entrega destes aos clientes) e também vantagens nos custos fixos dos depósitos (que têm economias de escala). Daí o benefício de um "agregador" que é o operador logístico. Deve-se mesmo mencionar 
que esta é uma tendência atual do panorama empresarial brasileiro: empresas contratarem o mesmo prestador de serviços logísticos para compartilhar ativos como centros de distribuição, veículos e outros equipamentos ou instalações com outros fabricantes (via de regra não-concorrentes).

Deve-se lembrar que a economia ocasionada pela consolidação dos fretes de transferência e de entrega final só justifica a abertura de um CD caso essa mesma economia sobrepuje os custos fixos de manter esta estrutura.

Poderia ser artificialmente montado um problema com uma única fábrica, a qual entrega volume muito grande de determinada classe de mercadoria. Porém, isto seria pouco realista: é melhor ter-se as diversas fábricas trabalhando em um volume plausível, dando maior autenticidade ao problema.

Foram montados, todavia, alguns cenários com as fábricas entregando isoladas; estes servirão para mostrar a importância de escala na distribuição física, além de possibilitar a melhor apreciação do aspecto geográfico e fiscal.

Além disso, a concepção de colocar fábricas em quatro Estados diferentes (uma em cada região, Sul, Sudeste, Centro-Oeste e Nordeste) foi motivada pelo desejo de se observar o impacto do ICMS na Logística em nível nacional e não do ponto de vista de um Estado ou Região em particular. Obviamente, isto pode gerar tradeoffs entre os diversos fabricantes devido à geografia e à economia diferenciada no país.

Parafraseando a descrição de Geoffrion e Graves (Ballou, 1999, Cap. 13), o problema então é: encontrar o número, a dimensão e os locais de centros de distribuição em uma rede física de distribuição que minimizarão custos fixos e variáveis e o débito do ICMS, através dos quais fluirão as mercadorias, sujeitas às seguintes condições:

1. Cada fábrica suporta uma única linha de produtos.

2. Cada fábrica tem capacidade de atender a demanda total desses produtos.

3. A demanda de cada produto deve ser integralmente satisfeita. 
4. O processamento em cada depósito não pode exceder a capacidade associada ao seu custo fixo anual.

5. A distribuição física é realizada com o auxílio de um operador logístico.

6. As entregas podem ser feitas diretamente dos depósitos das fábricas aos clientes ou por intermédio dos CD’s.

7. O mesmo cliente pode ser abastecido de CD’s diferentes ou direto da fábrica.

8. Praças importantes são atendidas em prazos determinados (nível de serviço).

9. Cada mercado é formado por clientes que desejam o crédito do ICMS (não sonegam) e por clientes indiferentes ao crédito (podem sonegar).

Deve-se frisar que está sendo usado o ponto de vista do operador logístico: ele vai procurar minimizar o custo total (distribuição física mais ICMS) para seus contratantes in toto, montando uma infraestrutura de depósitos para isto. Não é possível usar o ponto de vista de uma fábrica ou empresa de bens de consumo em particular pois podem existir tradeoffs entre as mesmas.

Deve-se comentar algumas hipóteses adicionais no modelo. Primeiro, não se impôs conjunto adicional de restrições exigindo que um nó de demanda deva ser atendido por um único $\mathrm{CD}$, utilizando variáveis binárias, conforme o modelo paradigmático de localização de CD’s (Geoffrion; Graves, 1974). Tal relaxação dá maior grau de liberdade para que o modelo considere os custos adicionais do ICMS, permitindo que uma localidade receba produtos de duas origens que estão em Estados diferentes. Isto também diminui o número de variáveis binárias e facilita a resolução.

Outro pressuposto é considerar apenas a cadeia de distribuição de produtos acabados. Assim, o cálculo do ICMS fica mais simples, pois não há agregação de valor na mercadoria devido a processos de transformação.

Finalmente, tal como no modelo de Geoffrion e Graves, não se considera explicitamente custos de estoques no sistema. Tal aproximação é tanto melhor quanto mais rápido o modal de transporte e maior o giro das mercadorias. 


\subsection{Descrição física do problema}

O problema envolve:

- Quatro linhas de produtos em quatro fábricas distintas.

- As fábricas estão localizadas nos municípios de São Paulo (Sudeste), Joinville (Sul), Goiânia (Centro-Oeste) e Recife (Nordeste).

- 51 locais candidatos a ter um CD (vide figura 3.1), pré-selecionados para obter adequada cobertura nacional.

- Clientes agregados em nível de messorregião do IBGE (excluindo-se certas porções da Amazônia, que não tem acesso rodoviário), num total de 122 messorregiões para o Brasil.

- Uso exclusivo do modal rodoviário (é típico desta operação).

A seleção dos locais das fábricas foi feita em função da importância desses centros para suas regiões (um por região) e do fato deles sediarem indústrias-líderes dos produtos selecionados para compor a análise (ver lista de produtos no item 3.4. Parâmetros do modelo).

Para escolher os 51 locais candidatos a possuir um $\mathrm{CD}$, foram usados como critérios:

- Ser entroncamento de rodovias importantes (boa acessibilidade rodoviária);

- Ser ponto de demanda concentrada na região (vantagem operacional); maior parte das capitais de Estados segue esta regra;

- Oferecer potencial vantagem do ponto de vista fiscal (proximidade de fronteiras de Estados, se possível mais de uma). 


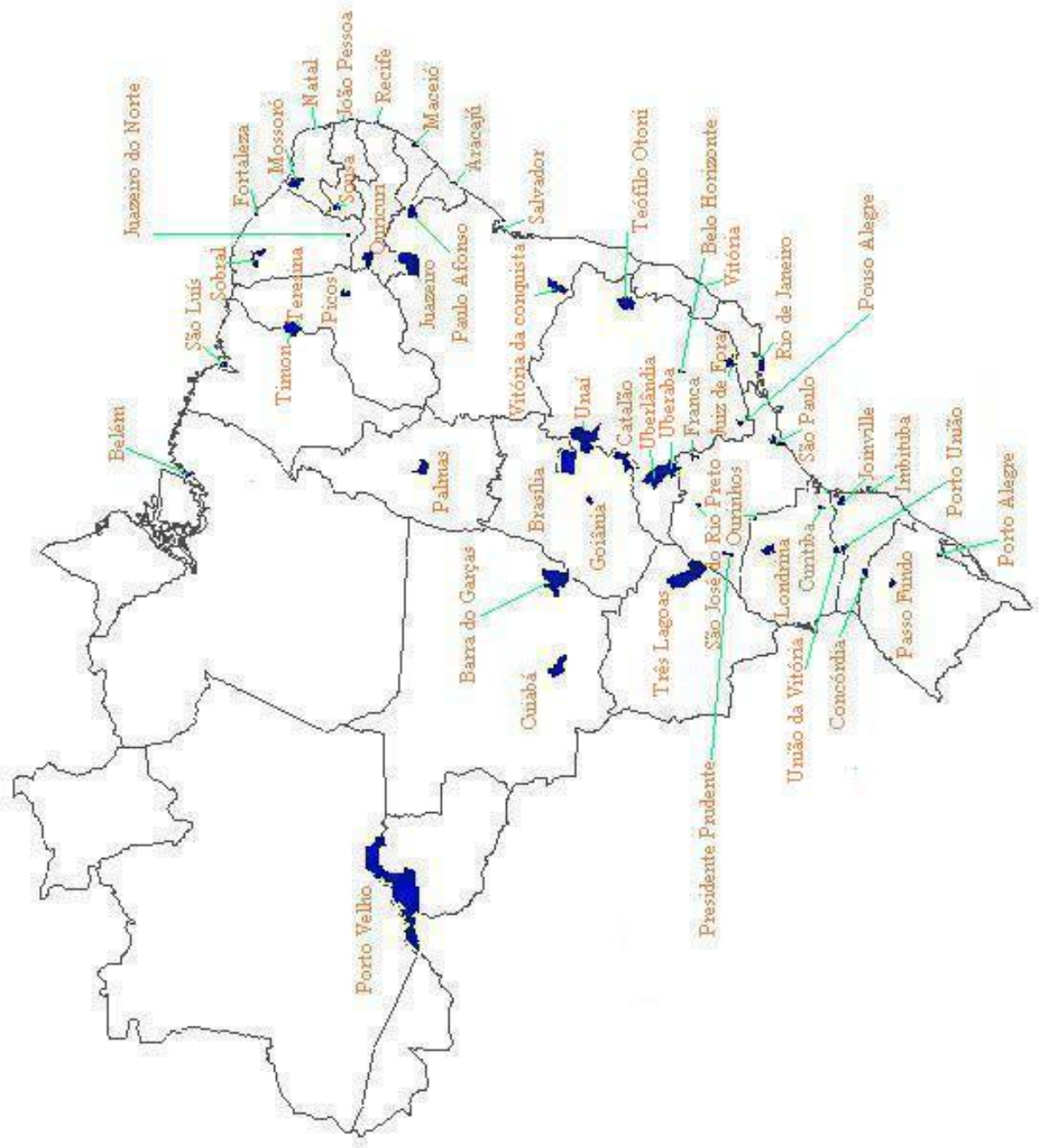

Figura 3.1. Municípios com possibilidade de abertura de CD's. 
Os sítios candidatos estão listados na Tabela 3.1, conforme a seqüência Sul para Norte, a partir de cima para baixo, esquerda para direita.

\begin{tabular}{|c|c|c|}
\hline Local candidado (Estado) & Local candidado (Estado) & Local candidado (Estado) \\
\hline Porto Alegre/RS & Juiz de Fora/MG & Maceió/AL \\
\hline Passo Fundo/RS & Pouso Alegre/MG & Recife/PE \\
\hline Imbituba/SC & Uberaba/MG & Ouricuri/PE \\
\hline Joinville/SC & Uberlândia/MG & João Pessoa/PB \\
\hline Concórdia/SC & Unaí/MG & Sousa/PB \\
\hline Porto União/SC & Teófilo Otoni/MG & Natal/RN \\
\hline Curitiba/PR & Três Lagoas/MS & Mossoró/RN \\
\hline Londrina/PR & Cuiabá/MT & Fortaleza/CE \\
\hline União da Vitória/PR & Barra do Garças/MT & Juazeiro do Norte/CE \\
\hline São Paulo/SP & Brasília/DF & Sobral/CE \\
\hline Ourinhos/SP & Goiânia/GO & Teresina/PI \\
\hline Presidente Prudente/SP & Catalão/GO & Picos/PI \\
\hline Franca/SP & Vitória da conquista/BA & São Luís/MA \\
\hline São José do Rio Preto/SP & Salvador/BA & Timon/MA \\
\hline Rio de Janeiro/RJ & Juazeiro/BA & Belém/PA \\
\hline Vitória/ES & Paulo Afonso/BA & Porto Velho/RO \\
\hline Belo Horizonte/MG & Aracaju/SE & Palmas/TO \\
\hline
\end{tabular}

Tabela 3.1. Locais candidatos a Centros de Distribuição

A agregação dos clientes em messoregiões do IBGE visa diminuir o porte do modelo a ser resolvido. Foram eliminadas partes da Amazônia legal, pois têm acesso rodoviário restrito e incrementariam artificialmente os custos logísticos. A lista completa das 137 messorregiões IBGE estão listadas no Anexo A. A lista completa de municípios, micro e messorregiões está no Anexo E. Mapas ilustrando a demanda dessas messoregiões estão no item 3.5.3. 


\subsection{Modelo matemático}

Para tratar o problema-objeto da pesquisa, foi desenvolvido um modelo matemático de Programação Linear Inteira Mista, descrito abaixo. Ele pode ser considerado como um aperfeiçoamento do problema de transbordo multiprodutos com custos fixos de instalação dos CD's, estes últimos tratados com variáveis binárias. Além disso, dado que existe economia de escala na operação de depósitos, principalmente no que tange a custos fixos de amortização de capital, depreciação e mão-de-obra direta, idealizou-se modelar tal fato usando-se variáveis binárias adicionais (Bueno Neto, 1988; Winston, 1995, cap. 9). Foi feita a consideração de vários produtos para permitir compartilhamento de custos fixos nos CD's, reduzindo custos para os envolvidos.

Índices (entre colchetes: número de elementos na dimensão)

$i$... Fábricas [4]

j ... Depósitos [51]

$k$... Mercados (agregados em mesorregiões) [122]

p ... Produtos (agregados por classes e setores, um por fábrica) [4]

$n$... Nível de depósito (indicador para custo fixo e capacidade de depósito) [10]

$s$... Nível de tributação ( $s=1$ para tributo incorporado na função objetivo - cliente indiferente ao crédito de ICMS, pois pode sonegar; e $s=2$ para tributo fora da função objetivo - cliente quer o crédito, pois não sonega) [2]

Parâmetros

$\operatorname{DemM}_{k p s} \ldots$ Demanda do produto $p$ no mercado $k$ com tributação ao nível $s$ (em t).

$\operatorname{CapD}_{j n} \ldots$ Capacidade do depósito $j$ no nível de capacidade $n(\mathrm{t})$.

$C a p F_{i p} \ldots$ Capacidade da fábrica $i$ para a classe de produto $p(\mathrm{t})$.

$\operatorname{CusT}_{i j} \ldots$... Custo unitário de transferência da fábrica $i$ para o depósito $j(\mathrm{R} \$ / \mathrm{t})$.

$C u s D_{j k} \ldots$ Custo unitário de distribuição do depósito $j$ para o mercado $k(\mathrm{R} \$ / \mathrm{t})$.

$\operatorname{CusF}_{i k} \ldots$ Custo unitário de distribuição da fábrica $i$ para o mercado $k(\mathrm{R} \$ / \mathrm{t})$. 
$\operatorname{CusB}_{j p} \ldots$... Custo unitário de transbordo da classe de produto $p$ no depósito $j(\mathrm{R} \$ / \mathrm{t})$.

$F i x D_{j n} \ldots$ Custo fixo do depósito $j$ com capacidade $n$, (R $\$ /$ ano).

CusI $_{j k}$... Taxa do ICMS na mercadoria na distribuição a partir do depósito $j$ para o mercado $k$.

CusIF $i k \ldots$ Taxa do ICMS na mercadoria na distribuição a partir da fábrica $i$ para o mercado $k$.

$\operatorname{CusM}_{p} \ldots$ Custo (preço) médio da classe de produto $p$ (no qual incide o ICMS), em $\mathrm{R} \$ / \mathrm{t}$.

FICMS ... Fator linear de indicação do nível de tributação $(0 \leq F I C M S \leq 1)$. Seja $\operatorname{Dem}_{k p}$ a demanda do produto $p$ no mercado $k(\mathrm{t})$, então:

$$
\begin{aligned}
& \operatorname{DemM}_{k p, s=1}=\operatorname{DemM}_{k p} * \text { FICMS } \\
& \operatorname{DemM}_{k p, s=2}=\operatorname{DemM}_{k p} *(1-F I C M S)
\end{aligned}
$$

Quando FICMS = 1, admite-se que todo o sistema paga 100\% do ICMS; quando $F I C M S=0$, admite-se que todo o sistema ignora o ICMS (sonega).

Variáveis

$T_{r n s} s_{i j p s}$... Quantidade transferida da classe de produto $p$ da fábrica $i$ para o depósito $j$ com nível de tributação $s$. (t)

$D_{s t r} D_{j k p s} \ldots$ Quantidade distribuída da classe de produto $p$ do depósito $j$ para o mercado $k$ com nível de tributação $s$. (t)

$D s t r F_{i k p s} \ldots$ quantidade distribuída da classe de produto $p$ da fábrica $i$ para o mercado $k$ com nível de tributação $s$. (t)

$Z_{j n} \ldots$ Assume valor 1 caso o depósito $j$ estiver operando no nível de depósito $n, 0$ em caso contrário.

$C T$... Custo total de operação (R $\$ / a n o)$. 
Restrições/Equações

Função de mérito, que é minimizar o custo total CT.

$$
\begin{aligned}
& \min C T=\sum_{i} \sum_{k} \sum_{p}\left\{\left[\left(C u s F_{i k}+C u s I F_{i k} \times C u s M_{p}\right) \times \sum_{s \mid s=1} D s t r F_{i k p s}\right]+\left[C u s F_{i k} \times \sum_{s \mid s=2} D s t r F_{i k p s}\right]\right\} \\
& +\sum_{i} \sum_{j} \sum_{p}\left(C u s T_{i j} \times \operatorname{Trns}_{i j p}\right) \\
& +\sum_{j} \sum_{k} \sum_{p}\left\{\left[\left(\operatorname{Cus}_{j k}+\operatorname{CusB}_{j}+\operatorname{CusI}_{j k} \times \operatorname{CusM}_{p}\right) \times \sum_{s \mid s=1} \operatorname{DstrD}_{j k p s}\right]+\left[\left(\operatorname{Cus}_{j k}+C u s B_{j}\right) \times \sum_{s \mid s=2} D_{s t r D} D_{j k p s}\right]\right\} \\
& +\sum_{j} \sum_{n} F i x D_{j n} \times Z_{j n}
\end{aligned}
$$

Restrição de atendimento da demanda da classe de produto $p$ no mercado $k$.

$$
\operatorname{DemM}_{k p s} \leq \sum_{i} D_{s t r} F_{i k p s}+\sum_{j} D_{s t r D}{ }_{j k p s}
$$$$
\forall k, \forall p, \forall s
$$

Restrição de capacidade de produção da classe de produtos $p$ na fábrica $i$.

$$
\sum_{i} \sum_{s} \operatorname{DstrF}_{i k p s}+\sum_{j} \sum_{s} \text { Trns }_{i j p s} \leq \text { CapF }_{i p} \quad \forall i, \forall p .
$$

Restrição de capacidade e operação do depósito $j$.

$\sum_{i} \sum_{p} \sum_{s} \operatorname{Trns}_{i j p s} \leq \sum_{n} Z_{j n} \times \operatorname{CapD}_{j n}$

$\forall j$.

Relação entre capacidades de depósitos.

$$
\begin{aligned}
& \sum_{n} Z_{j n}=1 \\
& \forall j \text {. }
\end{aligned}
$$

Balanço de massa da classe de produto $p$ no depósito $j$ com nível de tributação $s$.

$$
\sum_{i} \operatorname{Trns}_{i j p s}=\sum_{k} D s t r D_{j k p s} \quad \forall j, \forall p, \forall s .
$$

Não negatividade.

$$
\operatorname{Trns}_{i j p s} \geq 0 \quad \forall i, \forall j, \forall p, \forall s .
$$




$$
\begin{array}{ll}
D_{s t r} D_{j k p s} \geq 0 & \forall j, \forall k, \forall p, \forall s . \\
D s t r F_{i k p s} \geq 0 & \forall i, \forall k, \forall p, \forall s .
\end{array}
$$

Variáveis binárias.

$Z_{j n}=\left\{\begin{array}{l}1, \text { se deposito } j \text { com capacidade } n \text { ficar aberto } \\ 0, \text { em caso contrário }\end{array} \forall j, \forall n\right.$.

A função objetivo é composta por quatro parcelas, identificadas pelas quatro somatórias. Na primeira, temos o custo de distribuição direta a partir da fábrica $i$ para o mercado $k$, que é formado pelo produto de um custo variável pelo fluxo $i k$. Se o cliente desse mercado $k$ quiser o crédito de ICMS, apenas o custo de transporte $\left(C u s F_{i k}\right)$ deve ser considerado no custo variável (segunda parte da somatória, ou seja $s=2$ ), isto é, apenas a questão logística vai entrar no cômputo. Porém, se o cliente do mercado $k$ for indiferente a esse crédito ( $s=1$, isto é, pode sonegar), a empresa pode direcionar o fluxo para o local que for mais vantajoso do ponto de vista fiscal + logística, ou seja, pode se beneficiar do tradeoff logística vs. ICMS. Assim, na determinação do custo variável, tem-se a parcela do custo de transporte e do débito de ICMS: assim, o modelo deverá escolher o caminho que der o menor custo variável total (transporte e ICMS). O débito do ICMS é calculado em função da alíquota do produto para aquela origem destino $\left(C u s I F_{i k}\right)$ e do valor do produto $\left(C u s M_{p}\right)$. A segunda parcela (somatória) da função objetivo representa o custo do transporte de transferência fábrica-CD ij. A terceira parcela é o custo de distribuição a partir do CD $j$ para o mercado $k$, com a mesma lógica de construção feita para a distribuição fábrica-mercado na primeira parcela; sua diferença é que agora se deve acrescentar o custo variável $C u s B_{j}$ de manuseio (transbordo) no centro de distribuição. Finalmente, a quarta parcela representa o custo fixo do CD que for aberto no local $j$, em função de sua capacidade $n$.

O conjunto de restrições (3.2) representam o atendimento integral da demanda: para cada produto $p$ em cada mercado $k$, a demanda deve ser plenamente atendida. Essa demanda $k p$ está dividida entre demandas dos clientes $s=1$ e $s=2$ nas razões 
FICMS e (1- FICMS), respectivamente, ou seja, dividiu-se cada mercado conforme o fator de nível de tributação FICMS. Esse fator representa o nível de sonegação potencial no sistema. Isto significa que, em que cada mercado $k$, o agregado de sonegadores potenciais (indiferentes ao crédito do ICMS) e não-sonegadores (querem o crédito) dá a demanda total naquele mercado. FICMS é considerado constante para todos os mercados.

O conjunto de restrições (3.3) limita o escoamento de produtos $p$ à capacidade da planta industrial $i$ de fabricá-los. No problema estudado a capacidade das fábricas é irrestrita (ou seja, elas podem suportar toda a demanda).

As restrições (3.4) limitam o fluxo nos depósitos $j$ à sua capacidade de movimentação, que está associada ao nível $n$. Ou seja, cada local candidato pode abrir um entre $n$ tamanhos de CD.

O grupo de restrições (3.5) fazem com que haja pelo menos um depósito aberto no sítio candidato $j$. Para permitir ao modelo não abrir nenhuma instalação no local $j$, o nível $n=1$ tem capacidade de movimentação nula e custo zero.

O conjunto (3.6) representa o balanço de massa nos depósitos, ou seja, o fluxo de entrada é igual ao fluxo de saída. Os fluxos de mercadorias para clientes indiferentes ao ICMS $(s=1)$ são segregados dos fluxos de clientes que querem crédito $(s=2)$.

Finalmente, os grupos de restrições (3.7) e (3.8) são as usuais exigências de nãonegatividade ou valores binários para as variáveis de decisão.

Não há equação para o nível de serviço, pois o mesmo foi modelado através da distâncias máximas permitidas: os $\operatorname{arcos} i k$ ou $j k$ que correspondessem a uma distância acima da permitida eram simplesmente eliminados do modelo, ao invés de penalizá-los artificialmente com um valor muito grande na função objetivo (como preconizado em Love; Morris; Wesolowsky, 1988, p. 202). 


\subsection{Determinação dos parâmetros}

A seguir se detalham os parâmetros utilizados no modelo, como foram determinados e suas respectivas formas de cálculo.

\subsubsection{Mercados: regiões em estudo}

Os municípios foram agregados em 137 mesorregiões, conforme a base de dados IBGE de 1997 (Instituto Brasileiro de Geografia e Estatística, 2000).

As seguintes mesorregiões da Amazônia legal terão demanda igual a zero (messo/Estado):

- Vale do Acre/AC

- Vale do Juruá/AC

- Sul do Amapá/AP

- Norte do Amapá/AP

- Centro Amazonense/AM

- Norte Amazonense/AM

- Sudoeste Amazonense/AM

- Sul Amazonense/AM

- Baixo Amazonas/PA

- Marajó/PA

- Nordeste Paraense/PA

- Sudeste Paraense/PA

- Sudoeste Paraense/PA

- Norte de Roraima/RR

- Sul de Roraima/RR

Estas mesorregiões serão desconsideradas na análise em função da baixa densidade populacional e da pequena acessibilidade rodoviária, o que acarreta em uma demanda que está distante do enfoque dado no estudo. Além disso, elas também 
estão fora do escopo do levantamento de consumo per capita utilizado neste estudo. Elimina-se, assim, quinze mesorregiões, totalizando um total de 122 mesorregiões $(137-15=122)$.

Em termos populacionais, a população base do ano de 1997 era de 159.636.413 habitantes; desconsidera-se na análise 7.381 .371 pessoas (4,6\% da população), resultante da eliminação das 15 mesorregiões acima citadas. Tem-se, assim, 152.255.042 habitantes para a análise.

Os mercados estão ordenados alfabeticamente pelo Estado e pelo nome da mesorregião no Anexo A.

\subsubsection{Mercados: produtos}

Foram escolhidos para compor a análise os seguintes produtos: shampoo, sabonete, sabão em pó, detergente líquido de até 1 litro, desinfetante líquido de até 5 litros, amaciante de roupas, bolachas/biscoitos, massas alimentícias, extrato de tomate, molho de tomate, purê de tomate, conserva vegetal em lata, maionese e óleo de cozinha.

A seleção desses produtos atendeu aos seguintes critérios:

a) Disponibilidade de dados de consumo confiáveis (produtos levantados por agências de pesquisa).

b) Têm giro de estoque elevado.

c) Têm sazonalidade de consumo desprezível.

d) Compõem "cesta" de produtos facilmente encontrada em estabelecimentos varejistas (auto-serviço e mercearias) por todo o país.

e) Existem, para cada um deles, diversos fabricantes e marcas de alcance nacional, com escala de operação que permita distribuição física própria ou por terceiros (via operadores logísticos ou distribuidores e atacadistas).

f) Para todos eles existem marcas líderes com participação significativa de mercado (vide Tabela 3.2 a seguir). 


\subsubsection{Mercados: demanda, participação nas vendas, Market Share}

A demanda desses produtos é considerada diretamente proporcional à população da mesorregião, conforme dados de consumo per capita fornecidos pela ACNielsen ${ }^{4}$ (2001). Todos os produtos analisados não possuem sazonalidade de consumo. Os seguintes valores foram então compilados a partir das planilhas da ACNielsen para o ano 2000:

\begin{tabular}{|c|c|c|c|c|c|c|c|c|c|}
\hline \multirow[b]{2}{*}{ Categoria de Produto } & \multirow{2}{*}{$\begin{array}{l}\text { Share } 3 \\
\text { marcas }\end{array}$} & \multicolumn{7}{|c|}{ Consumo per capita/região } & \multirow[b]{2}{*}{ Unid. } \\
\hline & & I & II & III & IV & $\mathrm{V}$ & VI & VII & \\
\hline Shampoo & $43.20 \%$ & 0,306 & 0,522 & 0,611 & 0,810 & 0,855 & 0,690 & 0,505 & $\mathrm{~kg}$ \\
\hline Sabonete & $50.50 \%$ & 0,524 & 1,133 & 1,449 & 1,454 & 1,589 & 0,968 & 0,962 & $\mathrm{~kg}$ \\
\hline Sabão em pó & $65.00 \%$ & 1,368 & 2,911 & 4,114 & 4,231 & 4,043 & 2,762 & 2,580 & $\mathrm{~kg}$ \\
\hline Detergente líquido até 11 & $57.20 \%$ & 0,836 & 2,187 & 3,101 & 2,911 & 3,127 & 1,792 & 1,277 & 1 \\
\hline Desinfetante líquido até 51 & $28.00 \%$ & 0,623 & 1,486 & 1,539 & 1,343 & 1,901 & 0,990 & 1,347 & 1 \\
\hline Amaciante de roupas & $46.40 \%$ & 0,447 & 1,851 & 2,293 & 3,214 & 3,107 & 2,295 & 1,840 & 1 \\
\hline Bolachas/biscoito & $23.70 \%$ & 4,040 & 4,322 & 6,073 & 4,167 & 4,875 & 4,046 & 4,226 & $\mathrm{~kg}$ \\
\hline Massas alimentícias & $18.70 \%$ & 2,613 & 3,987 & 4,304 & 3,183 & 4,058 & 3,036 & 2,523 & $\mathrm{~kg}$ \\
\hline Extrato de tomate & $49.00 \%$ & 0,346 & 0,664 & 0,905 & 0,349 & 0,948 & 0,732 & 1,136 & $\mathrm{~kg}$ \\
\hline Molho de tomate até $1,1 \mathrm{~kg}$ & $73.00 \%$ & 0,107 & 0,368 & 0,579 & 1,240 & 1,154 & 0,283 & 0,278 & $\mathrm{~kg}$ \\
\hline Purê de tomate até $1,1 \mathrm{~kg}$ & $51.00 \%$ & 0,076 & 0,167 & 0,760 & 1,400 & 0,740 & 0,206 & 0,148 & $\mathrm{~kg}$ \\
\hline Conserva em lata & $47.00 \%$ & 0,216 & 0,490 & 0,668 & 0,642 & 0,766 & 0,607 & 0,377 & $\mathrm{~kg}$ \\
\hline Maionese & $72.70 \%$ & 0,230 & $\mathbf{0 , 5 3 0}$ & 0,806 & 0,773 & 0,810 & 0,823 & 0,438 & $\mathrm{~kg}$ \\
\hline Óleo de cozinha & $46.80 \%$ & 2,638 & 7,975 & 7,011 & 6,329 & 9,663 & 6,213 & 6,719 & $\mathrm{~kg}$ \\
\hline
\end{tabular}

Tabela 3.2. Tabela com consumo per/capita (Fonte AC Nielsen, 2001)

A segunda coluna dá a participação de mercado (em volume) das três principais marcas daquela categoria de produto. A seguir, tem-se os consumos per capita conforme as áreas ACNielsen. A cobertura das pesquisas ACNielsen abrange 87,7\% da população brasileira e $90 \%$ do consumo nacional. As áreas ACNielsen, que obedecem a divisão geopolítica de Estados e Municípios, são as seguintes:

\footnotetext{
${ }^{4}$ Planilhas eletrônicas com dados de consumo per capita por região da ACNielsen Brazil de todas as categorias de produtos, para o ano de 2000, foram gentilmente cedidas por esse instituto, através da sra. Simone Nascimento Silva.
} 
- ÁREA I: Ceará, Rio Grande do Norte, Paraíba, Pernambuco, Alagoas, Sergipe e Bahia.

- ÁREA II: Minas Gerais, Espírito Santo e Estado do Rio de Janeiro (excluindo-se os municípios contidos na ÁREA III).

- ÁREA III: Grande Rio de Janeiro: Rio de Janeiro, Niterói, Nova Iguaçu, Duque de Caxias, Nilópolis, São Gonçalo e São João de Meriti.

- ÁREA IV: Grande São Paulo: São Paulo, Santo André, São Bernardo do Campo, São Caetano do Sul, Diadema, Mauá, Guarulhos, Osasco, Embu e Taboão da Serra.

- ÁREA V: Interior do Estado de São Paulo (excluindo-se os municípios contidos na ÁREA IV).

- ÁREA VI: Paraná, Santa Catarina e Rio Grande do Sul.

- ÁREA VII: Mato Grosso do Sul, Goiás e Distrito Federal.

Tem-se também as capitais do Norte: Belém, Manaus, São Luiz e Teresina. As Capitais do Norte representam 2,4 \% da população e 2,3\% do consumo nacional.

Com o uso desta tabela obtém-se o consumo líquido de cada mercado considerado. Como o estudo está parametrizado em valor por peso bruto transportado ( $R \$ / t)$, é necessária a conversão do consumo liquido para toneladas brutas (inclui embalagem primária, secundária, rótulo, etc). Para isso utilizou-se a tabela abaixo, obtida via pesquisa de campo ou entrevistas ${ }^{5}$.

\begin{tabular}{|l|c|c|c|c|}
\hline Produto & Unidade & Coversão $l$ para $k g$ & Relação ton. Liquida/bruta & Market Share \\
\hline
\end{tabular}

\footnotetext{
${ }^{5}$ Visitas com pesagens diretas em um atacadista (Makro) ou dados fornecidos pelos srs. André Júlio Szabo (Controle da Qualidade, Grupo Pão de Açúcar), Wagner Alexandre de Carvalho (Logística, Santista Alimentos) e Eduardo Oliveira (Logística, Unilever/Best Foods)
} 


\begin{tabular}{|c|c|c|c|c|}
\cline { 3 - 4 } Shampoo & $\mathrm{kg}$ & --- & 0,8446 & \multirow{2}{*}{$1 / 3$} \\
\hline Sabonete & $\mathrm{kg}$ & --- & 0,9346 & $1 / 3$ \\
\hline Sabão em pó & $\mathrm{kg}$ & --- & 0,9360 & $1 / 3$ \\
\hline Detergente líquido até 11 & 1 & $1 l=1 \mathrm{~kg}$ & 0,9231 & $1 / 3$ \\
\hline Desinfetante líquido até 51 & 1 & $1 l=1 \mathrm{~kg}$ & 0,9465 & $1 / 3$ \\
\hline Amaciante de roupas & 1 & $1 l=1 \mathrm{~kg}$ & 0,9457 & $1 / 3$ \\
\hline Bolachas/biscoito & $\mathrm{kg}$ & --- & 0,9328 & $1 / 3$ \\
\hline Massas alimentícias & $\mathrm{kg}$ & --- & 0,9783 & $1 / 3$ \\
\hline Extrato de tormate & $\mathrm{kg}$ & --- & 0,8043 & $1 / 3$ \\
\hline Molho de tomate até $1,1 \mathrm{~kg}$ & $\mathrm{~kg}$ & --- & 0,8043 & $1 / 3$ \\
\hline Purê de tomate até $1,1 \mathrm{~kg}$ & $\mathrm{~kg}$ & --- & 0,5511 & $1 / 3$ \\
\hline Conserva vegetal & $\mathrm{kg}$ & --- & 0,8929 & $1 / 3$ \\
\hline Maionese & $\mathrm{kg}$ & --- & 0,9250 & $1 / 3$ \\
\hline Óleo de cozinha & $\mathrm{kg}$ & --- & & \\
\hline
\end{tabular}

Tabela 3.3. Conversão demanda tonelada líquida para bruta

Para obtenção da demanda do estudo, convencionou-se que a mesma seria equivalente às demandas de um fabricante com participação de mercado equivalente a um terço do "Market Share" das três principais marcas (tabela 3.3). O estudo irá considerar, então, a demanda da uma única marca líder de mercado, conforme a última coluna da tabela. Isto então representa uma indústria importante naquele segmento, e de alcance nacional (não necessariamente a maior).

Assim, a demanda de cada produto foi calculada como:

Demanda na mesorregião $=($ população $) \times($ per capita da região $) \times($ taxa de conversão para peso bruto) $\mathrm{x}(1 / 3) \mathrm{x}$ (market share das três principais marcas)

As seguintes demandas totais anuais serão consideradas para cada produto:

\begin{tabular}{|l|l|l|}
\hline Produto & Demanda anual (t) & Local da Fábrica \\
\hline
\end{tabular}




\begin{tabular}{|c|c|c|}
\cline { 3 - 3 } Shampoo & $14.420,30$ & Recife / PE \\
\hline Sabonete & $27.725,49$ & Recife / PE \\
\hline Sabão em pó & $96.524,80$ & São Paulo / SP \\
\hline Detergente líquido até 1 1 & $59.088,78$ & São Paulo / SP \\
\hline Desinfetante líquido até 5 1 & $17.354,33$ & São Paulo / SP \\
\hline Amaciante de roupas & $44.956,62$ & São Paulo / SP \\
\hline Bolachas/biscoito & $56.083,01$ & São Paulo / SP \\
\hline Massas alimentícias & $31.251,36$ & São Paulo / SP \\
\hline Extrato de tomate & $19.235,29$ & Goiânia / GO \\
\hline Molho de tomate até 1,1 kg & $21.623,58$ & Goiânia / GO \\
\hline Purê de tomate até 1,1 kg & $12.689,41$ & Goiânia / GO \\
\hline Conserva em lata & $20.494,30$ & Goiânia / GO \\
\hline Maionese & $22.833,63$ & Goiânia / GO \\
\hline Óleo de cozinha & $149.636,51$ & Joinville / SC \\
\hline
\end{tabular}

Tabela 3.4. Demanda anuais totais para cada produto (peso bruto total)

O volume totaliza uma demanda de 593.917,42 t/ano.

A designação de produtos às fábricas obedece aos seguintes critérios concomitantes:

- Existência de indústrias tradicionais do ramo na região.

- Produto não é sujeito à substituição tributária no Estado em questão.

- Volume total por fábrica é decrescente na seguinte ordem: São Paulo $(305.258,90$ t), Santa Catarina $(149.636,44$ t), Goiás $(96.876,18$ t) e Pernambuco (42.145,76 t).

As Figuras 3.2 a 3.5, a seguir, mostram mapas das demandas por mesorregião para o agregado de cada fábrica. Para dar uma melhor visualização da concentração de demanda em determinadas regiões, a Figura 3.6 expõe um mapa com relevo tridimensional para o caso de produtos com origem em São Paulo (como é o maior volume, diferenças ficam com maior realce; reparar a concentração nas duas maiores mesorregiões - Metropolitanas de São Paulo e Rio de Janeiro). 

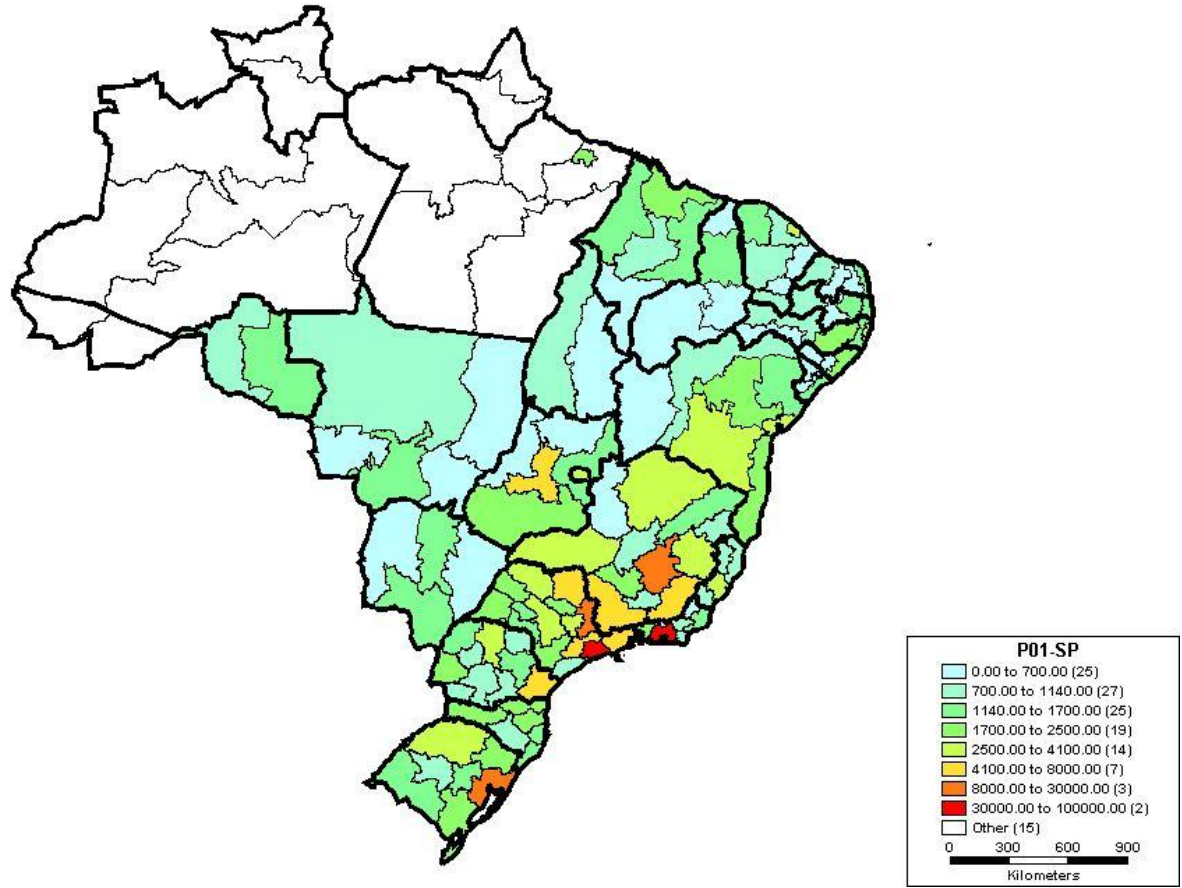

Figura 3.2. Demanda (em toneladas) dos produtos com origem na fábrica SP.
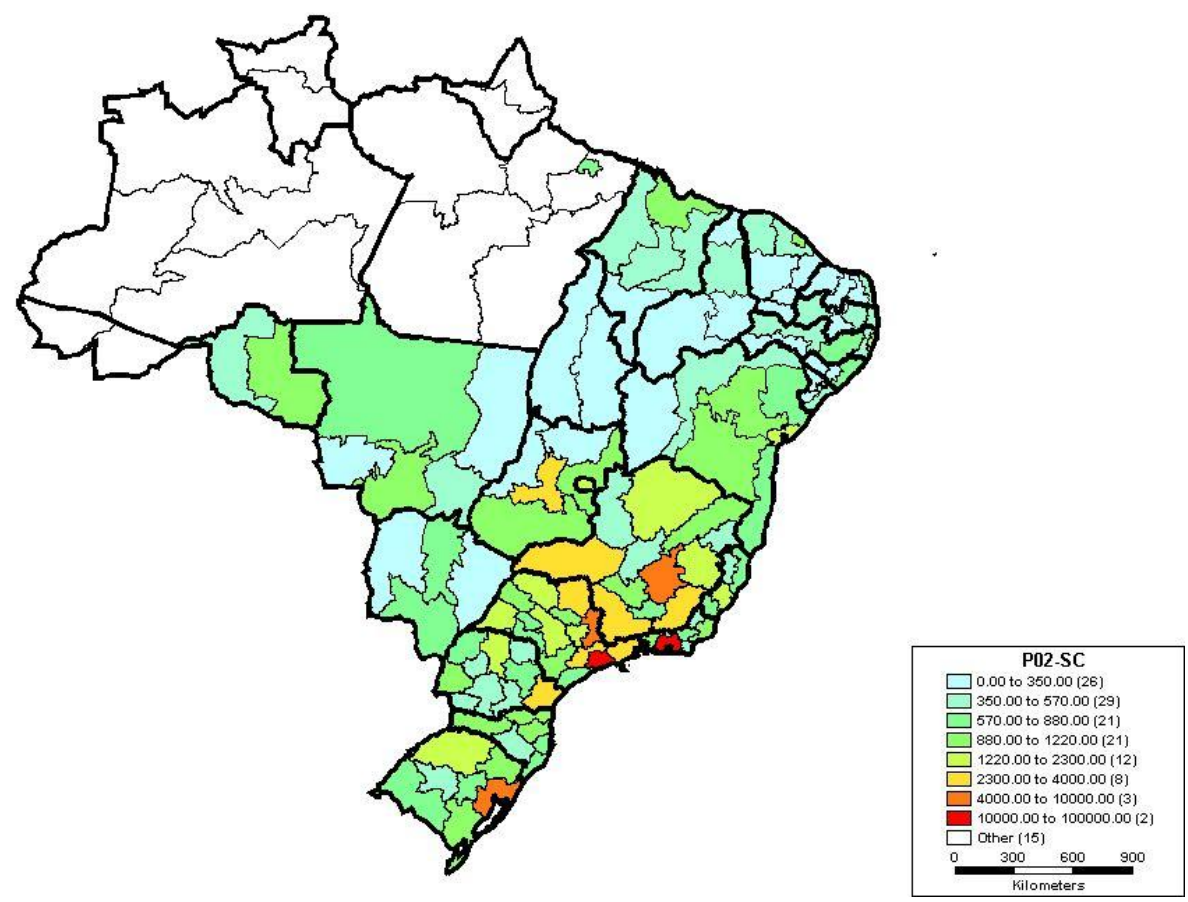

Figura 3.3. Demanda (em toneladas) dos produtos com origem na fábrica SC. 

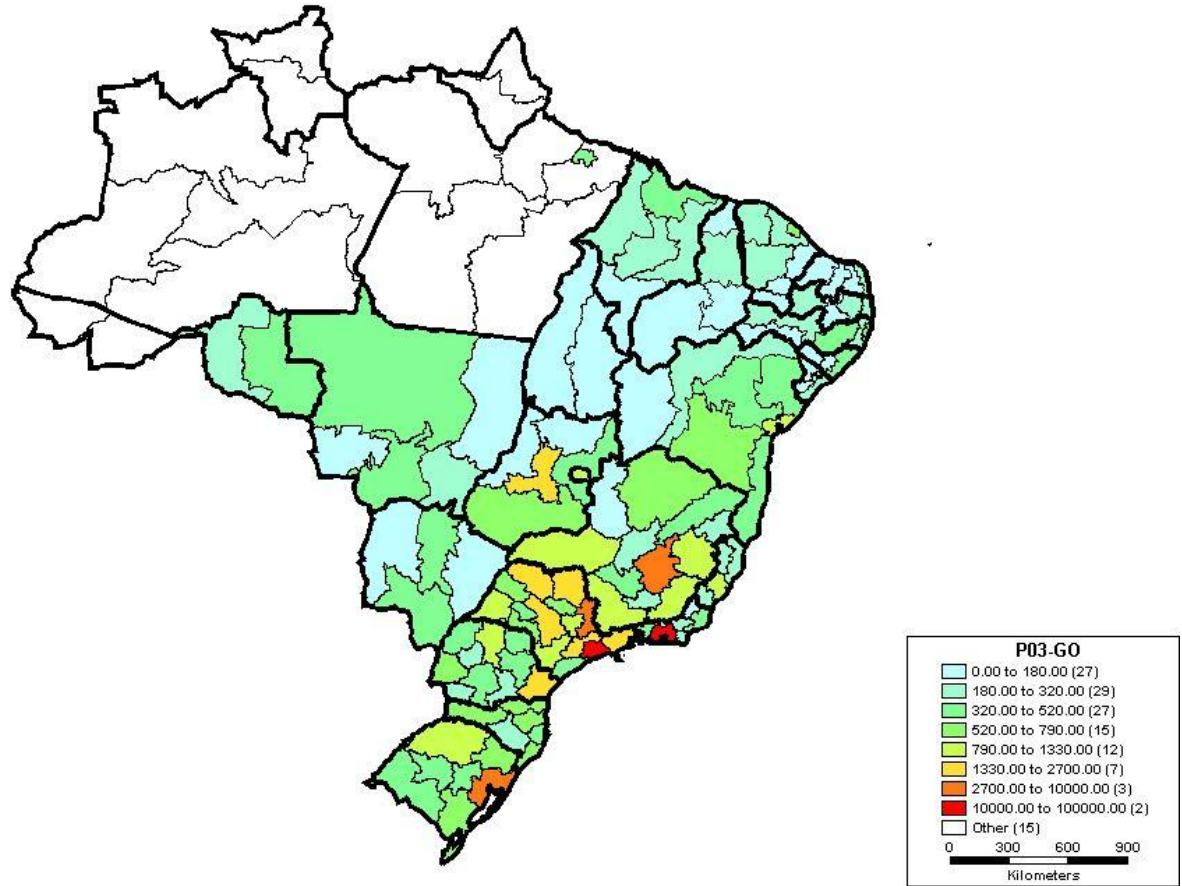

Figura 3.4. Demanda (em toneladas) dos produtos com origem na fábrica GO.
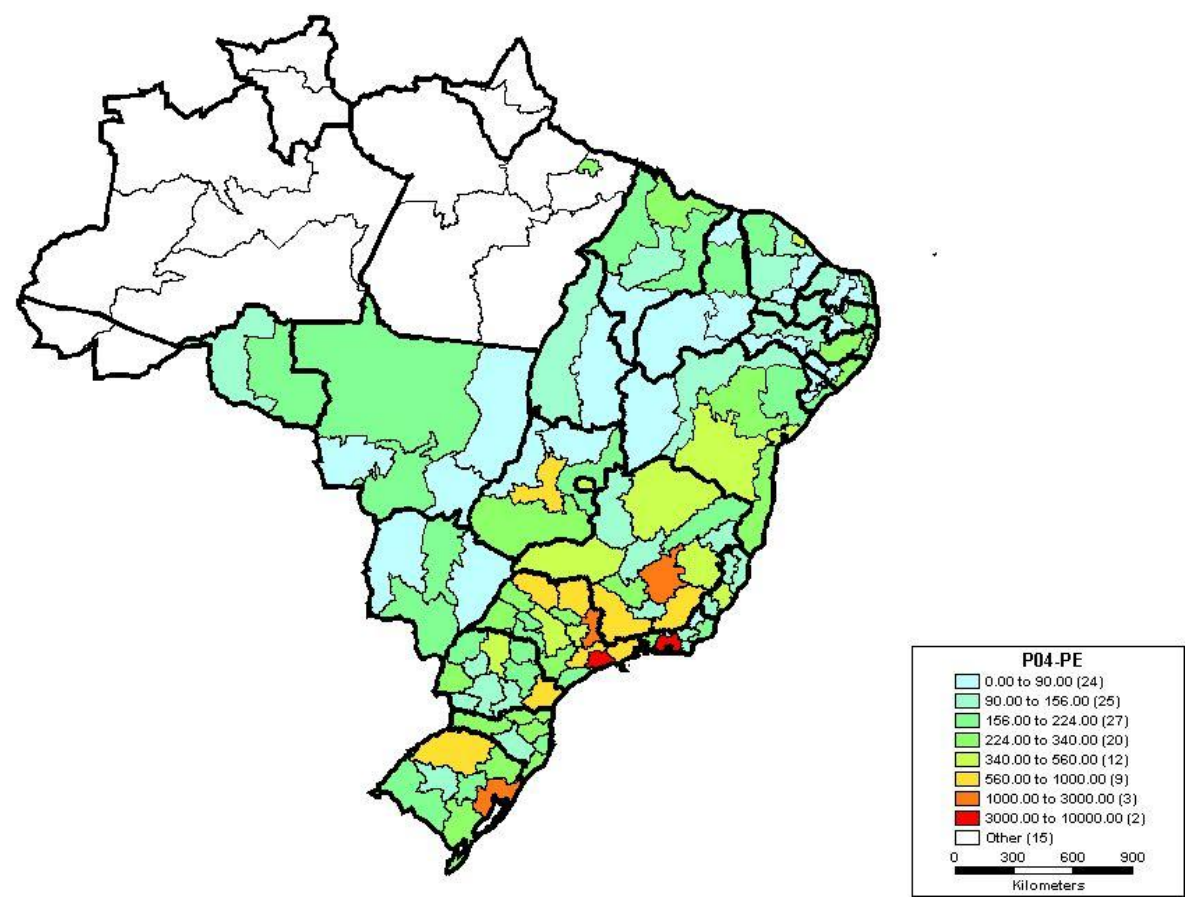

Figura 3.5. Demanda (em toneladas) dos produtos com origem na fábrica PE 


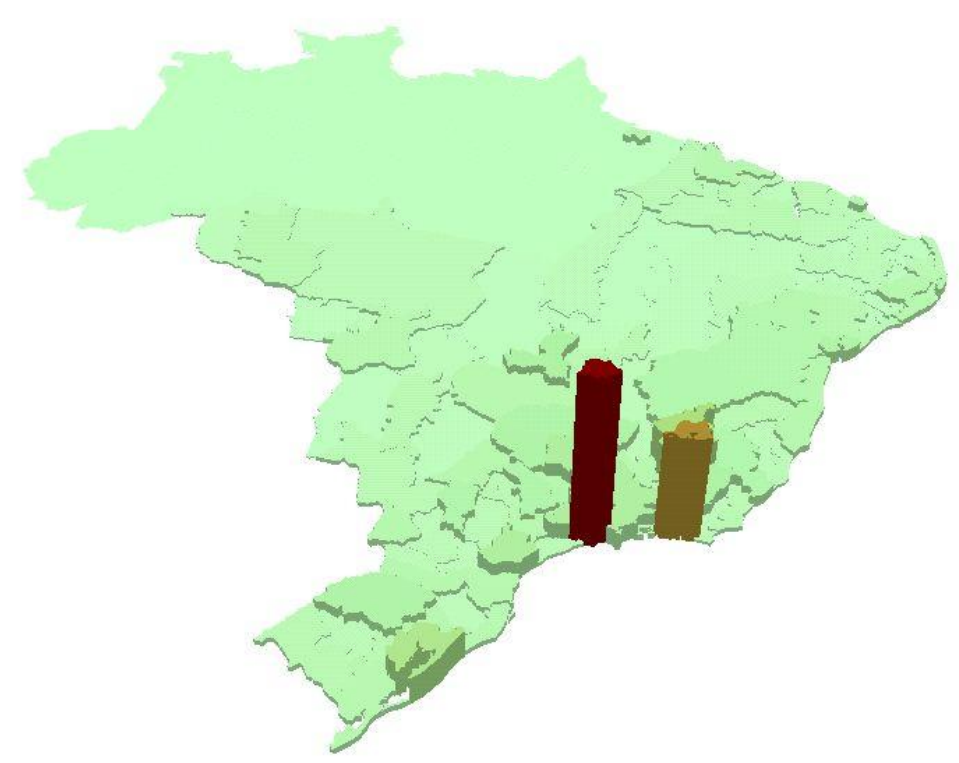

Figura 3.6. Demanda com origem na fábrica SP com relevo tridimensional.

\subsubsection{Mercados: níveis de interesse no crédito de ICMS}

Adotou-se fator linear para indicar o nível de pagamento de tributos pelos clientes em cada mercado, sendo considerados somente dois níveis: $100 \%$ de pagamento e 0\% de pagamento (sonegação). Isto é, um determinado cliente paga totalmente seus tributos ou não; não há cliente que sonegue apenas parte de suas mercadorias (como ocorre na prática).

Por exemplo: seja $D$ a demanda de um mercado e $f$ o fator linear de indicação do nível de pagamento (1 - FICMS no modelo). A demanda deste mercado ficará assim dividida:

- Clientes que pagam $100 \%$ da tributação $=f * D$; (quer crédito);

- Clientes que pagam $0 \%$ de tributação $=(1-f) * D ;$ (não precisa do crédito); 
Ou seja, se $f=1$, todo o sistema paga $100 \%$ do ICMS devido e, portanto, tem interesse no crédito do imposto; se $f=0$, todo o sistema ignora (sonega) a tributação de ICMS e fica indiferente ao crédito do imposto. Convém ressaltar que $0 \leq f \leq 1$.

\subsubsection{Capacidade de fábricas:}

Infinita, para atender hipótese de atendimento completo da demanda.

\subsubsection{Capacidade dos depósitos:}

Foram empregados 10 níveis $n$, conforme tabela a seguir (o limite de 300.000 t/ano foi definido após consulta a especialistas do mercado $^{6}$ ):

\begin{tabular}{|c|c|}
\hline Nível de Capacidade & Capacidade anual (t/ano) \\
\hline N_1 & 0 (fechado) \\
\hline N_2 & 10.000 \\
\hline N_3 & 20.000 \\
\hline N_4 & 35.000 \\
\hline N_5 & 50.000 \\
\hline N_6 & 75.000 \\
\hline N_7 & 100.000 \\
\hline N_8 & 150.000 \\
\hline N_9 & 200.000 \\
\hline N_10 & 300.000 \\
\hline
\end{tabular}

Tabela 3.5. Níveis de capacidade nos depósitos ou CD’s.

\footnotetext{
${ }^{6}$ Discussões realizadas com os srs. Eduardo Mariath (Diretor, Cesamar Logística), Ricardo Monteiro (Customer Logistics, Procter\&Gamble), Francisco Tabajara de Brito (Danzas Logística, Diretor Geral), Gilmar Winck (Qualidade e Desenvolvimento, CDA Carrefour) e Roberto Vilarinho (então Diretor, Supply Chain Management, Divisão Kibon, Unilever).
} 


\subsubsection{Frete de transferência:}

Utiliza-se uma regressão linear de dados históricos (Fundação Vanzolini, 2000) em função da distância esférica (Ballou, 1999, Cap. 14) entre a fábrica e o depósito (D) em km:

$$
C_{\text {frete_transf }}=11,1573+0,0516 \times D \text {, }
$$

com $r^{2}=0,9730$. A amostra usada tem 33 pontos, com distâncias variando entre mínimo de 0 e máximo de 3.100 km.

\subsubsection{Frete de distribuição (via Centro de Distribuição e via Fábricas)}

Utiliza-se uma regressão linear de dados históricos (Fundação Vanzolini 2000) em função da distância esférica (Ballou, 1999, Cap. 14) entre a depósito ou fábrica e o mercado (D) em km:

$C_{\text {frete_distro }}=19,4512+0,077 \times D$,

com $r^{2}=0,743$. A amostra usada tem 110 pontos (já sem outliers), com distâncias variando entre 0 e $1200 \mathrm{~km}$.

\subsubsection{Distâncias}

As distâncias usadas foram calculadas entre os centros populacionais das mesorregiões e os municípios (dos locais candidatos, i.e., fábricas e depósitos potenciais) medidos em linha "reta" (distância medida no arco de circunferência em coordenadas esféricas nas latitudes e longitudes da origem e destino, cf. Ballou, 1999, Cap. 14).

\subsubsection{ICMS:}

Foi calculado com base na tabela do CONFAZ (vide anexo B.1). 


\subsubsection{Custo (preço) do produto $(\mathrm{R} \$ / \mathrm{t})$}

A princípio adota-se $\mathrm{R} \$ 2.500,00 / \mathrm{t}$ como preço de venda para todos os produtos (aproximadamente o valor médio de mercado na época do levantamento dos dados Fundação Vanzolini, 2000).

\subsubsection{Custo de transbordo (variável)}

Foi adotado R \$ 1,00/t baseado em dados históricos (Fundação Vanzolini 2000).

\subsubsection{Custo fixo de depósito}

Foi usada a seguinte relação:

$$
C_{\text {fixo_ } C D}=984.550,00 \times\left(\frac{T}{35.000}\right)^{0,845351},
$$

onde T é a movimentação anual do CD em toneladas (Fundação Vanzolini, 2000). Essa curva de ajuste para o custo fixo é válida para centros de distribuição de mercadorias secas acondicionadas em caixas de papelão ondulado, que é o tipo de produto enfocado neste estudo. Foram usados custos conhecidos (reais) de seis centros de distribuição diferentes mas com procedimentos de operação iguais, com movimentações (capacidades) anuais entre 18.000 t e 54.000 t. O depósito padrão tinha capacidade de 35.000 t/ano, considerando-se que o custo fixo aumenta aproximadamente $80 \%$ caso a capacidade dobre (ganho de escala).

Assume-se também que o custo variável de um CD (transbordo da mercadoria) é constante, não importando o tamanho do CD; os ganhos de escala estão associados aos custos fixos de instalação e operação (Fundação Vanzolini, 2000). 


\subsubsection{Nível de serviço}

A restrição de nível de serviço de prazo máximo foi adaptada como tempo de viagem em função da distância. Usualmente, para grandes centros metropolitanas empresas de bens de consumo de massa procuram atendimento no prazo máximo de um dia e dois dias para centros menores. Adaptando-se esse critério, em função de velocidades médias e assumindo um esquema comercial ágil, tem-se a restrição de distância máxima para atender as mesorregiões com maior população, conforme Tabela 3.6.

\begin{tabular}{|c|c|}
\hline População da mesorregião & $\begin{array}{c}\text { Distância máxima para } \\
\text { atendimento }\end{array}$ \\
\hline Menor que 2.000 .000 & sem limites \\
\hline entre 2.000 .000 e 3.000 .000 & $750 \mathrm{~km}$ \\
\hline maior que 3.000 .000 & $500 \mathrm{~km}$ \\
\hline
\end{tabular}

Tabela 3.6. Restrição de nível de serviço.

A Tabela 3.7 a seguir lista as mesorregiões mais populosas e, portanto, que exigem uma instalação de distribuição no raio estabelecido acima. A Figura 3.7 ilustra essas mesorregiões; olhando-se o mapa, pode-se imaginar então que as mesorregiões mais populosas devem exercer um papel preponderante na atração e abertura de CD’s.

\begin{tabular}{|l|r|l|c|}
\hline Mesorregião & $\begin{array}{c}\text { População } \\
\text { (hab.) }\end{array}$ & Mesorregião & $\begin{array}{c}\text { População } \\
\text { (hab.) }\end{array}$ \\
\hline Metropolitana de São Paulo/SP & 18.057 .268 & Metropolitana de Curitiba/PR & 2.824 .030 \\
\hline Metropolitana do Rio de Janeiro/RJ & 10.895 .848 & Metropolitana de Fortaleza/CE & 2.714 .849 \\
\hline Metropolitana de Belo Horizonte/MG & 5.166 .628 & Centro Sul Baiano/BA & 2.503 .456 \\
\hline Metropolitana de Porto Alegre/RS & 4.122 .959 & Centro Goiano/GO & 2.362 .897 \\
\hline Metropolitana de Salvador/BA & 3.433 .390 & Sul/Sudoeste de Minas/MG & 2.128 .601 \\
\hline Metropolitana de Recife/PE & 3.132 .354 & Centro Norte Baiano/BA & 2.111 .933 \\
\hline Campinas/SP & 3.050 .528 & Macro Metropolitana Paulista/SP & 2.023 .238 \\
\hline
\end{tabular}

Tabela 3.7. População das principais mesorregiões 


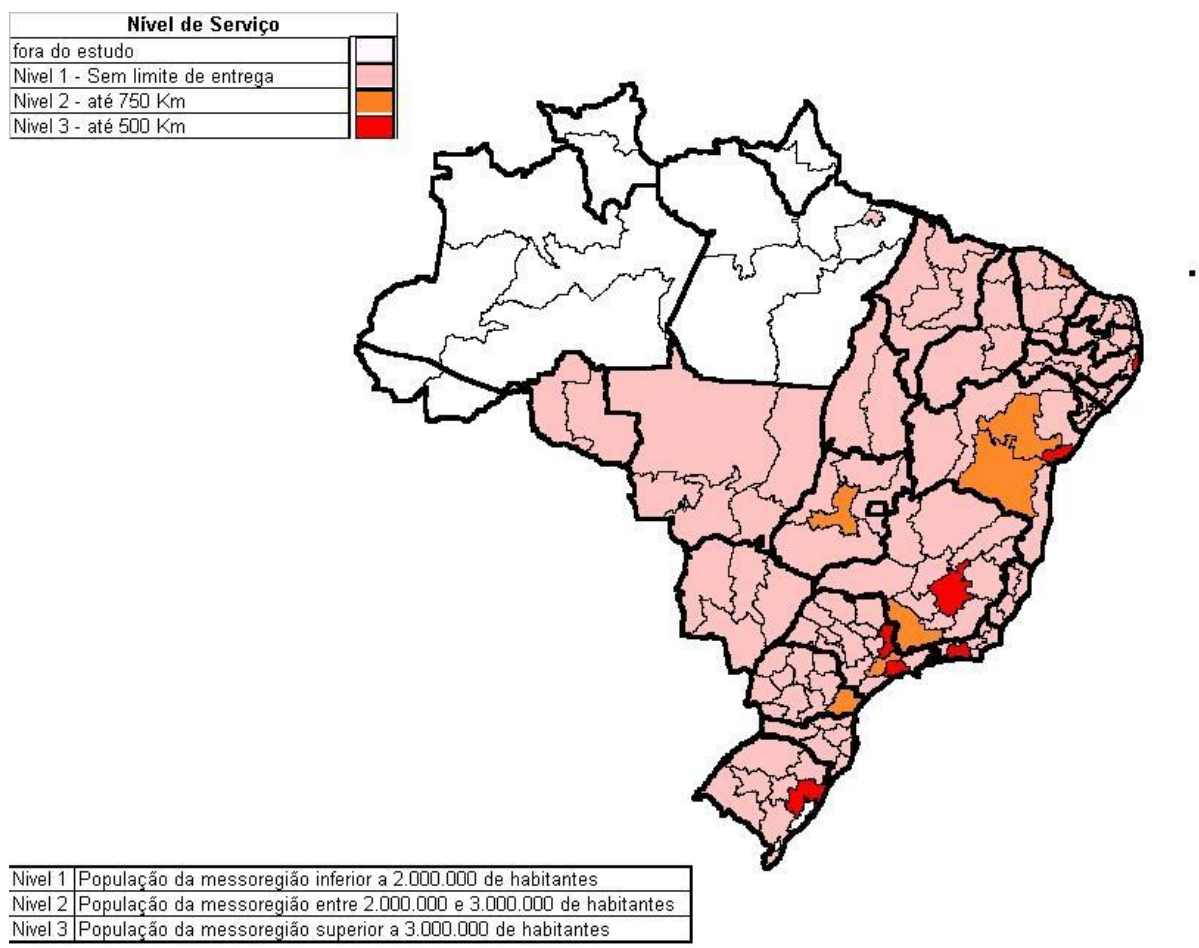

Figura 3.7. Nível de serviço por mesorregião.

\subsection{Processamento do modelo}

O modelo foi implementado utilizando-se como linguagem de manipulação algébrica o GAMS 2.50 (Rosenthal, 1992; Brooke et al., 1998) e o CPLEX 7.0, como solver. O emprego do GAMS facilita sobremaneira a codificação do modelo e das suas diversas instâncias ou cenários (Godoy; Yoshizaki, 1995; Hino, 1999). O uso do CPLEX se faz necessário devido à dimensão do problema, principalmente no que diz respeito ao número de variáveis binárias (Bixby, 2002). Utilizou-se para o cálculo um computador com processador Pentium 4® 1,7 Ghz com 512 MB de memória RAM. Para a plotagem dos mapas, foram usados os sistemas de informações geográficas SPRING e MAPTITUDE 4.0.

O modelo do cenário básico final tem cerca de 62.000 variáveis reais, 510 binárias, 1.600 restrições e 190.000 parâmetros, podendo ser considerado de médio porte. 
Durante o desenvolvimento e calibragem do modelo, foram processados mais de uma centena de cenários diferentes. Por exemplo, o tempo de processamento do modelo é bastante sensível a determinadas condições, como o nível de serviço. Iniciou-se utilizando como ponto de corte a população de um milhão de habitantes para o nível de distância máxima de 750 km (vide Figura 3.8). Nesse caso, havia a necessidade de abrir-se mais CD’s de pequeno porte e o número de ramificações analisadas crescia exponencialmente. Determinados cenários demoravam mais de 8 horas para chegar a soluções com discrepância absoluta dentro da tolerância $(\mathrm{R} \$ 1,50)$.
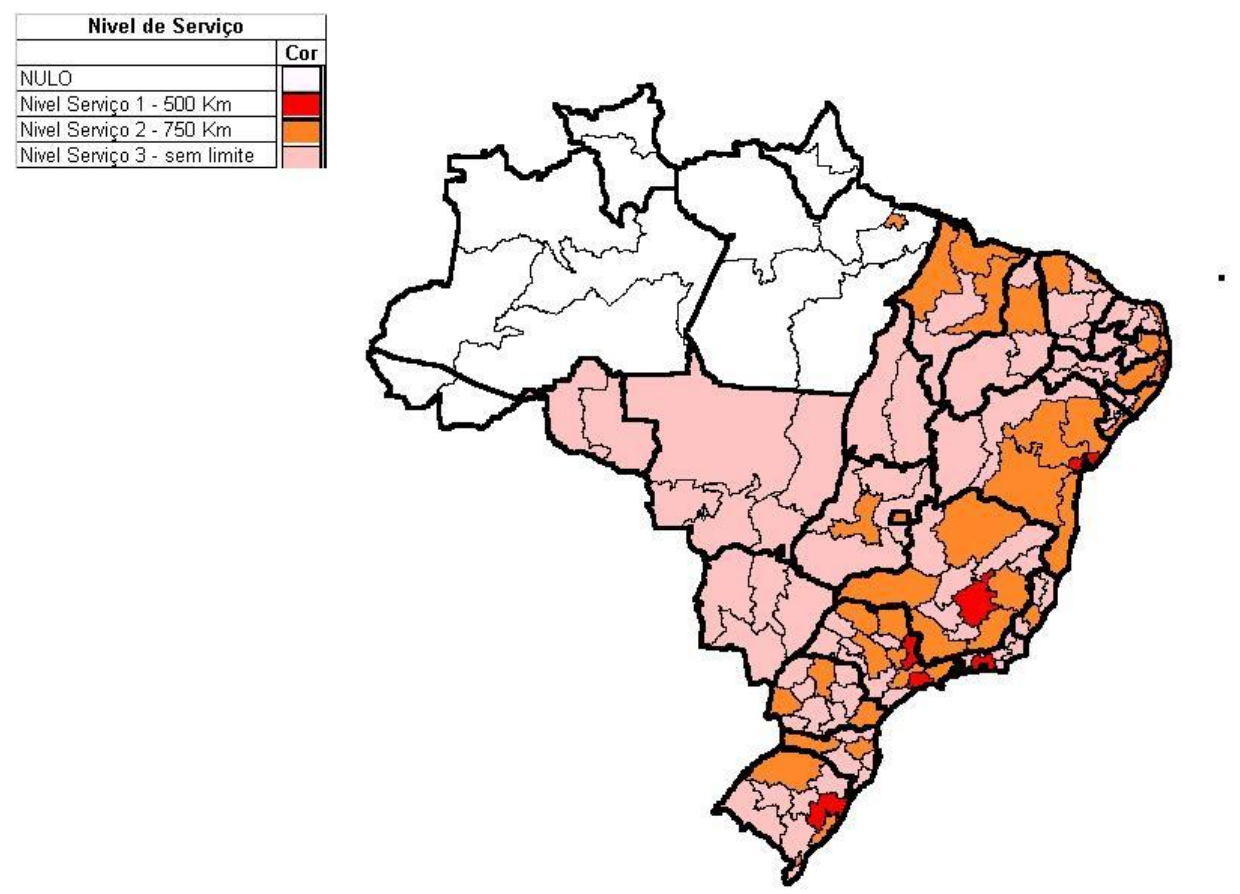

Figura 3.8. Mesorregiões com nível de serviço original (comparar com figura anterior)

A quantidade de pequenos CD’s em locais de baixa demanda tornava a solução, apesar de ótima, pouco factível de implementação em um caso real. Após consulta a diversos especialistas do setor de bens de consumo, viu-se que a prática de mercado definia o nível de serviço como finalmente foi adotado na pesquisa (vide item anterior e Figura 3.8) e o tempo de processamento ficou significativamente menor. 
Outro ponto a ser calibrado foi o volume total: para alguns produtos, estimou-se de forma exagerada a participação de mercado. Além disso, o valor de venda do produto também influencia: quanto menor, mais tradeoffs precisam ser avaliados no processo de branch \& bound. Esse aspecto é explorado na análise de sensibilidade. Com as medidas tomadas, os tempos de processamento dos cenários finais acabaram variando entre alguns segundos e duas horas. Foram então avaliados 47 cenários finais, sendo possível obter a solução ótima em todos eles, com a exceção de três, que interromperam o processamento antes ( a tolerância relativa - diferença entre solução candidata e bound inferior - havia sido fixada em $10^{-8}$ ). Seus resultados estão descritos no capítulo seguinte. 


\section{RESULTADOS OBTIDOS}

Este capítulo apresenta inicialmente os resultados do modelo aplicado ao problema de projeto de rede de distribuição para uma única origem, isto é, como se cada fábrica estivesse fazendo sua distribuição independentemente das demais. Isto permitirá uma entrada gradual nas características do problema. Em seguida, são mostrados os resultados do cenário básico multiprodutos, onde agora as quatro fábricas/origens distribuem conjuntamente seus produtos através de um único operador logístico. Posteriormente, a análise de sensibilidade do cenário-base para o índice de sonegação e o preço de venda médio é mostrada. Ao final, conclusões são elaboradas para orientar a discussão do capítulo 5 .

Vale a pena recordar que o modelo matemático descrito no item 3.3 trata de um problema com seis índices: fábricas, depósitos, mercados, produtos, dimensões dos depósitos e nível de indiferença ao ICMS, sendo os três primeiros indicadores espaciais (localidades). Porém, o problema analisado tem na prática quatro dimensões:

- Fábricas $=$ produtos $($ classes de produtos são agregadas apenas a uma fábrica)

- Mercados.

- Origens (CD’s ou fábricas).

- Sonega ou não.

Mesmo com esse número reduzido de dimensões, é difícil descrever e analisar os resultados, pois a mente humana tem limitações para tratar questões multidimensionais. Isto é exacerbado pelo uso da PLIM, que avalia todos os tradeoffs simultaneamente, incluindo variáveis binárias (a rigor, uma nãolinearidade). Tentou-se minimizar essa questão empregando-se profusamente agregações, gráficos parametrizados, tabelas, mapas etc. Vez ou outra, porém, foi preciso ir à minúcia dos resultados. 


\subsection{Cenários com indústrias individuais}

Vai-se apresentar primeiramente os resultados aplicados às fábricas distribuindo seus produtos de forma isolada, pois servirão para introduzir algumas idiossincrasias do problema. Cada fábrica pode abastecer mais de uma linha de produtos.

Para verificar se a alteração na rede logística em função do potencial de sonegação do ICMS é realmente significativa, vai-se empregar dois cenários-limites ou puros: sonegação assumida na cadeia é zero (ou seja, apenas os custos logísticos influenciam o custo e o projeto da rede logística otimizada) e sonegação assumida de 100\% (influência máxima do ICMS). A Tabela 4.1 mostra os custos logísticos, de ICMS e totais para as diversas fábricas, de forma a promover a comparação entre origens diferentes e entre os dois cenários (sem e com sonegação) Além disso, as diferenças absolutas e relativas desses custos são expostas à direita. Detalhes de componentes do custo logístico para cada origem estão no Anexo C.

\begin{tabular}{|c|c|c|c|c|c|}
\hline \multirow{2}{*}{$\begin{array}{c}\text { Fábrica de } \\
\text { origem }\end{array}$} & \multirow[b]{2}{*}{ Custos } & \multicolumn{2}{|c|}{ Cenário } & \multicolumn{2}{|c|}{ Diferença $(0 \%-100 \%)$} \\
\hline & & $\begin{array}{c}\text { 0\% soneg } \\
\text { (R\$ milhões) }\end{array}$ & $\begin{array}{l}\text { 100\% soneg. } \\
\text { (R\$ milhões) }\end{array}$ & $\begin{array}{c}\text { Absoluta } \\
\text { (R\$ milhões) }\end{array}$ & Relativa \\
\hline \multirow{3}{*}{$\begin{array}{c}\text { São Paulo } \\
\text { SP }\end{array}$} & Logística & 22,79 & 28,62 & $-5,84$ & $-25,6 \%$ \\
\hline & Débito ICMS & 106,18 & 82,55 & 23,64 & $22,3 \%$ \\
\hline & TOTAL & 128,97 & 111,17 & 17,80 & $13,8 \%$ \\
\hline \multirow{3}{*}{$\begin{array}{c}\text { Joinville } \\
\text { SC }\end{array}$} & \begin{tabular}{|l|} 
Logística \\
\end{tabular} & 13,95 & 14,84 & $-0,90$ & $-6,4 \%$ \\
\hline & Débito ICMS & 45,70 & 40,54 & 5,17 & $11,3 \%$ \\
\hline & TOTAL & 59,65 & 55,38 & 4,27 & $7,2 \%$ \\
\hline \multirow{3}{*}{$\begin{array}{c}\text { Goiânia } \\
\text { GO }\end{array}$} & Logística & 10,27 & 11,54 & $-1,27$ & $-12,4 \%$ \\
\hline & Débito ICMS & 35,32 & 26,88 & 8,44 & $23,9 \%$ \\
\hline & TOTAL & 45,60 & 38,43 & 7,17 & $15,7 \%$ \\
\hline \multirow{3}{*}{$\begin{array}{c}\text { Recife } \\
\text { PE }\end{array}$} & Logística & 7,31 & 7,89 & $-0,58$ & $-8,0 \%$ \\
\hline & Débito ICMS & 14,81 & 11,94 & 2,87 & $19,4 \%$ \\
\hline & TOTAL & 22,12 & 19,83 & 2,28 & $10,3 \%$ \\
\hline
\end{tabular}

Tabela 4.1.Comparação de custos das diversas origens. 
Como era esperado, ocorreu uma compensação entre custo logístico e débito de ICMS: observando os custos nos dois cenários, para cada origem diferente, houve um aumento no custo logístico com a contrapartida de uma redução substancial do ICMS a pagar. Os incrementos nos custos logísticos estão destacados nas duas colunas da direita.

Pode-se perceber que os aumentos relativos são diferentes conforme a origem, assim como a redução proporcional do ICMS e do custo total. Isto é efeito de diversos fatores: a geografia das fábricas, depósitos e mercados, a escala de operação, etc, além do ICMS, redundando em maior ou menor "turismo" da mercadoria.

Vai-se verificar primeiro o CD de Goiânia pois é o que tem maior redução relativa de ICMS e de custo total. Pode se conferir se está ocorrendo o "turismo" visualmente: foram preparados mapas com as áreas de influência dos CD’s e da fábrica de Goiânia nas figuras 4.1 e 4.2 a seguir. Repare-se que, para a pintura dos mapas, a mesorregião fica com a cor da origem com maior volume de entregas para o local (se proveniente da fábrica, é entrega DIRETA; se não, tem o nome do depósito associado).
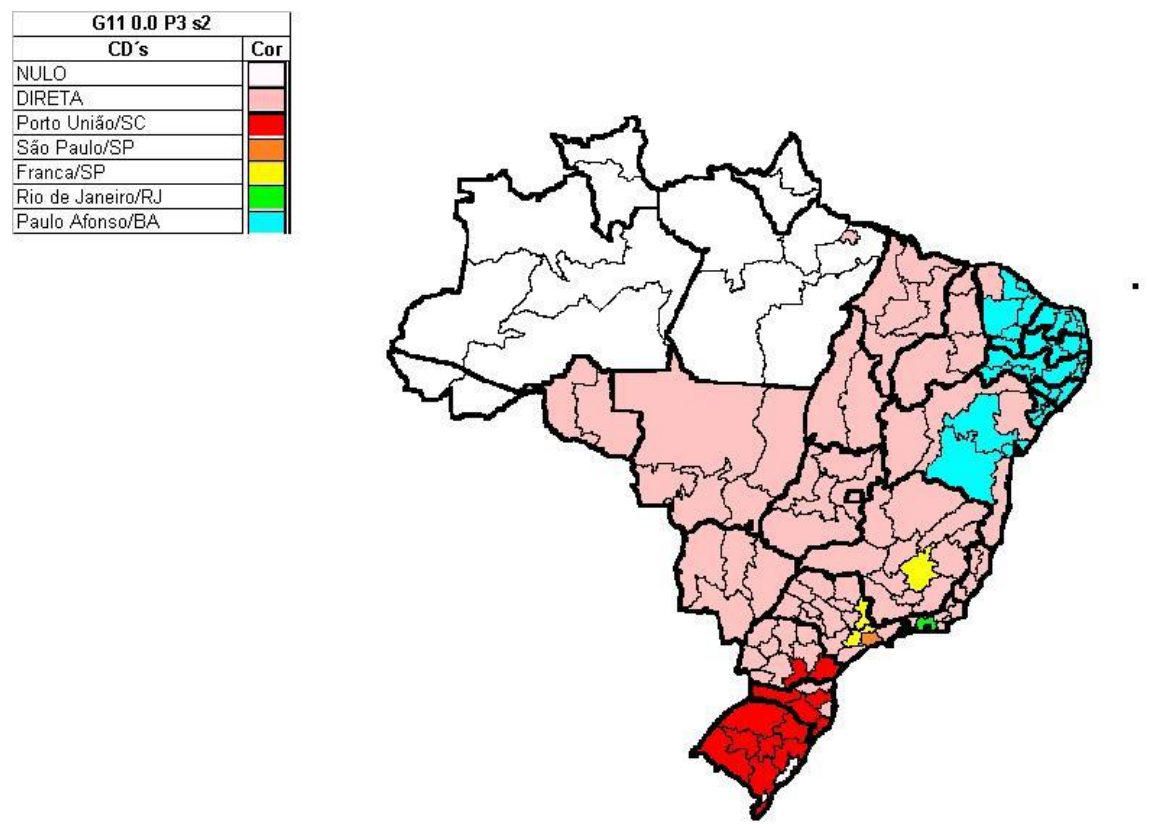

Figura 4.1. Áreas de influência de fábrica e CD’s, origem GO, sonegação assumida $0 \%$. 

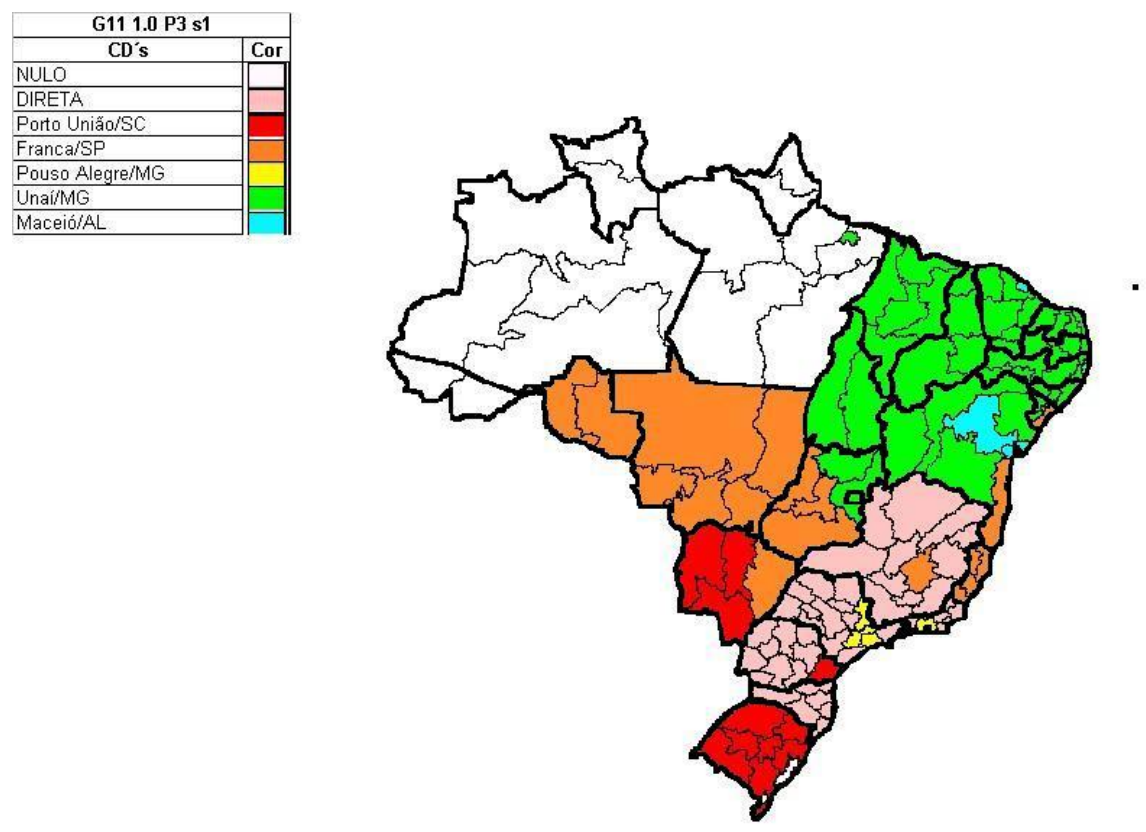

Figura 4.2. Áreas de influência de fábrica e CD’s, origem GO, sonegação assumida 100\%.

A existência do "turismo" é insofismável: na Figura 4.2 vê-se o caso do produto que sai de Goiânia, vai até Franca (SP) e volta para a mesorregião (área laranja). Isto é um bom exemplo de "passeio do ICMS". Vai-se agora discutir em detalhe.

Explore-se primeiramente a Figura 4.1, onde não há influência do ICMS: temos que grande quantidade das praças é atendida diretamente, pois o pequeno volume a ser distribuído não compensa o custo fixo extra de abrir e manter depósitos. Como ilustração, na fase de calibração do modelo, mesmo para um volume distribuído de Goiânia seis vezes maior, ao se relaxar a restrição de nível de serviço, todas as praças eram atendidas diretamente. Portanto, os depósitos são abertos por causa da exigência de nível de serviço e não por vantagens de frete.

São cinco, conforme a Tabela 4.2 abaixo: 


\begin{tabular}{|c|c|c|c|}
\hline Depósito & Localização $^{\mathbf{a}}$ & Principais praças atendidas & $\begin{array}{c}\text { Volume } \\
\text { movimentado }\end{array}$ \\
\hline Porto União/SC & $\begin{array}{l}\text { NO de SC, divisa com } \\
\text { PR }\end{array}$ & $\begin{array}{l}\text { Todo RS e boa parte de SC e PR, } \\
\text { incluindo Metropolitana de Curitiba }\end{array}$ & $10.000 \mathrm{t}$ \\
\hline São Paulo/SP & Grande São Paulo & Somente Metropolitana de São Paulo & $20.000 \mathrm{t}$ \\
\hline Franca/SP & NE de SP, divisa de MG & $\begin{array}{l}\text { Campinas, Macro Metropolitana } \\
\text { Paulista e Metropolitana de São } \\
\text { Paulo }^{7} \\
\text { Metropolitana de Belo Horizonte } \\
\text { Metropolitana do Rio de Janeiro } \\
\text { Metropolitana de Curitiba }\end{array}$ & $10.000 \mathrm{t}$ \\
\hline Rio de Janeiro/RJ & Grande Rio de Janeiro & Metropolitana do Rio da Janeiro & $10.000 \mathrm{t}$ \\
\hline Paulo Afonso/BA & $\begin{array}{l}\text { NE da BA, divisa com } \\
\text { SE e AL, próximo da } \\
\text { divisa com PE }\end{array}$ & $\begin{array}{l}\text { Quase todo Nordeste, incluindo } \\
\text { Metropolitanas de Salvador e de } \\
\text { Recife }\end{array}$ & $7.652 \mathrm{t}$ \\
\hline
\end{tabular}

Tabela 4.2. Áreas de influência dos CD’s para origem GO, sonegação assumida $0 \%$.

Com exceção do CD de Paulo Afonso/BA, todos os outros estão no limite de suas capacidades, que agem como restrição ativa. Ou seja, para aumentar a capacidade, deve-se absorver um aumento de custo fixo que não é justificado pelos volumes e nível de serviço. Isto é percebido pelo fato do $\mathrm{CD}$ de Porto União ter uma área de influência que não é contígua, com diversas mesorregiões próximas (inclusive uma vizinha) atendidas diretamente da fábrica de Goiânia. Obviamente, esse CD foi aberto para atender Metropolitana de Porto Alegre: dado que ele está aberto, ou seja, dado que o custo marginal de entregar por este CD é agora apenas o custo de transbordo ( $\mathrm{R}$ \$ 1,00/t), várias outras regiões se aproveitam desse fato. A avaliação dos tradeoffs colocou algumas mesorregiões de SC fora de sua área de atuação.

É interessante notar que o CD de Franca/SP precisa atender três grandes "massas", que são Campinas, a Metropolitana de Belo Horizonte e a Macro Metropolitana Paulista/SP (que contém a cidade de Jundiaí). Os volumes atendidos são,

\footnotetext{
${ }^{7}$ Reparar que a mesorregião Metropolitana de São Paulo é atendida a partir de dois depósitos (São Paulo e Franca), o que não seria possível usando-se o modelo de Geoffrion e Graves (1975).
} 
respectivamente, $3.464,41$ t, 2.916,40 t e 2.297,74 t. Franca também está em um ponto onde pode abastecer as outras grandes áreas metropolitanas de São Paulo, Rio e Curitiba. Assim, ela atende o saldo desses locais que não puderam ser abastecidos de seus respectivos CD’s.

Observando-se agora a Figura 4.2, três depósitos foram fechados (São Paulo, Rio e Paulo Afonso) e substituídos (não esquecer que é necessário abrir CD’s por causa do nível de serviço) por Pouso Alegre/MG e Maceió/AL. Pouso Alegre cuida dos grandes mercados paulistas e cariocas; Maceió abastece Salvador, Recife e Fortaleza. Obviamente isto é um efeito do ICMS, que vai então forçar a abertura de CD’s fora dos Estados onde há grande concentração de demanda para se beneficiar das alíquotas interestaduais reduzidas. Naturalmente, certos casos configuram um "turismo" de produtos muito claro: tem-se Franca/SP abastecendo grande parte do Centro-Oeste ou Porto União/SC enviando mercadorias para o Oeste de Mato Grosso do Sul. Outros casos não são tão evidentes. Por exemplo, o fato de Pouso Alegre/MG abastecer São Paulo ou o Rio de Janeiro poderia ser classificado como "má logística" e não necessariamente "turismo" do ICMS: afinal, o CD está em um ponto intermediário entre as duas maiores massas de consumo. O mesmo se aplicaria ao caso do CD de Maceió/AL.

Porém, há um novo depósito em Unaí, que fica no Noroeste de MG, divisa com Goiás e próximo a Brasília. Ele atende boa parte do Nordeste brasileiro, parcelas de Goiás e o Distrito Federal. A única mesorregião atendida por critérios de nível de serviço é o Centro Sul Baiano/BA; todos os outros mercados são por conveniência de ICMS. Isto acontece porque a alíquota interestadual de MG para as regiões atendidas por Unaí é de apenas 7\% (vide Tabela B.1) contra os 12 \% normais; assim, o CD de Unaí é aberto por questões fiscais. Ele gera muitos exemplos de turismo, como o retorno de mercadoria para Goiás e Brasília. A abertura desse CD vai acontecer em muitos cenários posteriores.

Ele também suscita uma versão curiosa da discussão "turismo" versus "má logística": para atender certas porções do mercado do Nordeste e Norte, Unaí está, 
por assim dizer, "no caminho", entre a fábrica e seus mercados. Porém, ao contrário do que acontece normalmente (quando apenas custos logísticos entram em consideração) o CD está muito mais próximo da fábrica que dos mercados. O ICMS subverte a intuição normal do raciocínio logístico.

Essa "subversão" da Logística pelo ICMS é facilmente constatável se observarmos os mapas correspondentes aos outros casos (vide Figuras 4.3 a $4.8^{8}$ ). Vale a pena lembrar que a distribuição é isolada, ou seja, cada fábrica tem uma logística própria e independente. Pode-se constatar o "turismo" de produtos em diversas ocasiões. Com origem São Paulo, tem-se esse Estado sendo abastecido a partir de CD em Pouso Alegre/MG, ou Salvador/BA abastecido do CD Aracaju/SE. Para a fábrica de Joinville/SC, todo o Estado de SC é atendido a partir de um depósito em Ourinhos, Sudoeste de SP. E, para a instalação de Recife/PE, temos o Estado de PE atendido a partir de CD em Maceió/AL.

\footnotetext{
${ }^{8}$ Os mapas dos cenários ilustrados no Capítulo 4 e todos os mapas dos cenários com distribuição conjunta e preço médio de $\mathrm{R} \$ 2.500,00 / \mathrm{t}$ (itens 4.2 e 4.3) estão no Anexo D (CD-ROM).
} 

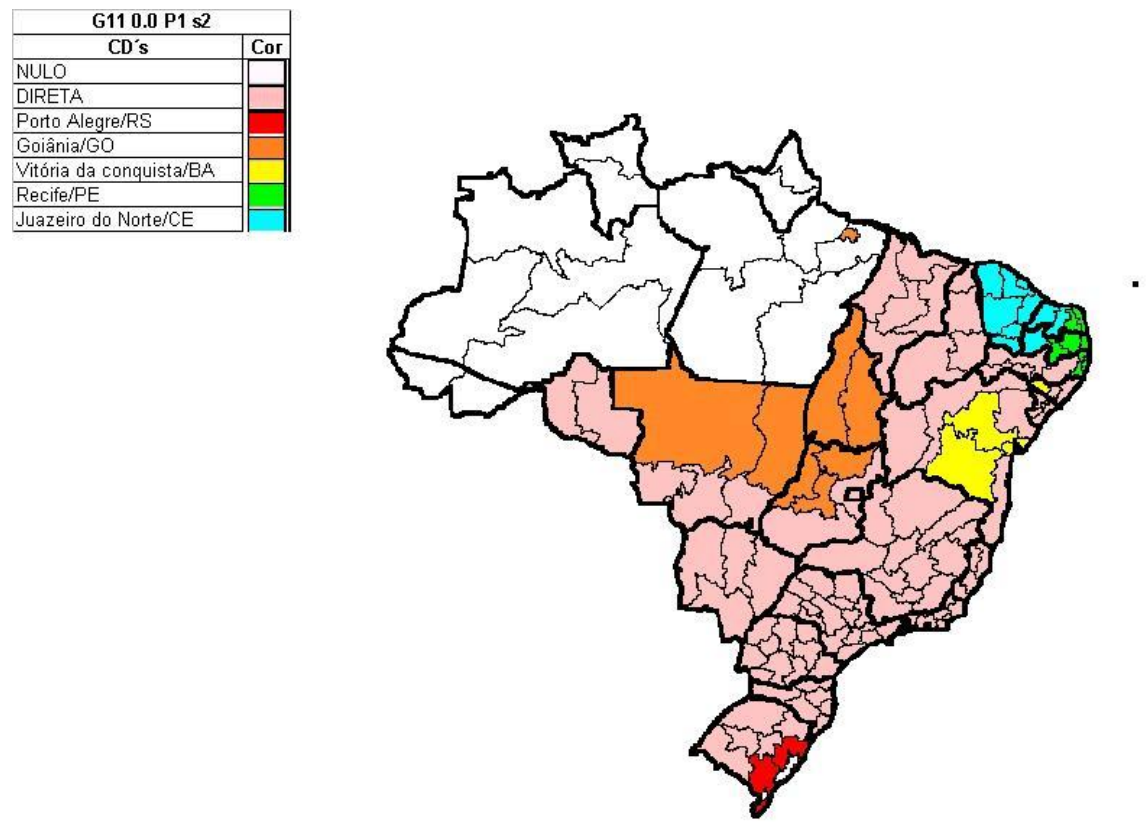

Figura 4.3. Áreas de influência de fábrica e CD’s, origem SP, sonegação assumida $0 \%$.
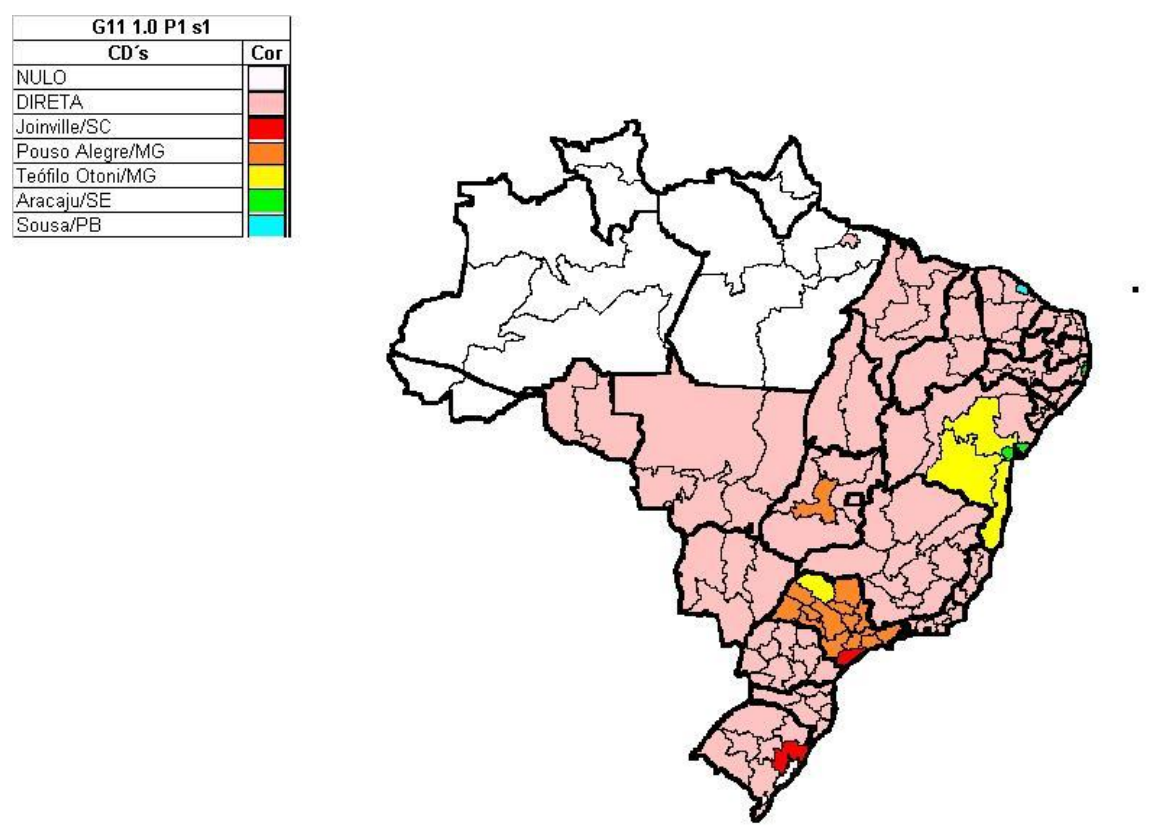

Figura 4.4. Áreas de influência de fábrica e CD’s, origem SP, sonegação assumida $100 \%$. 

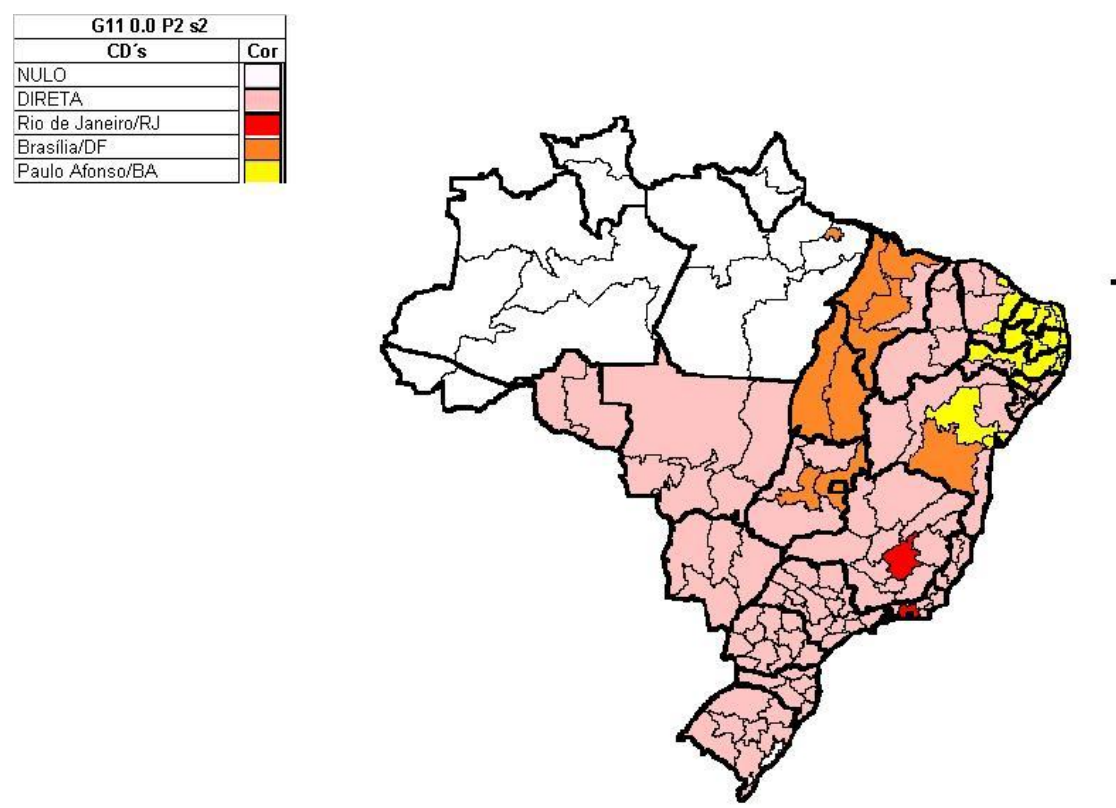

Figura 4.5. Áreas de influência de fábrica e CD’s, origem SC, sonegação assumida $0 \%$.
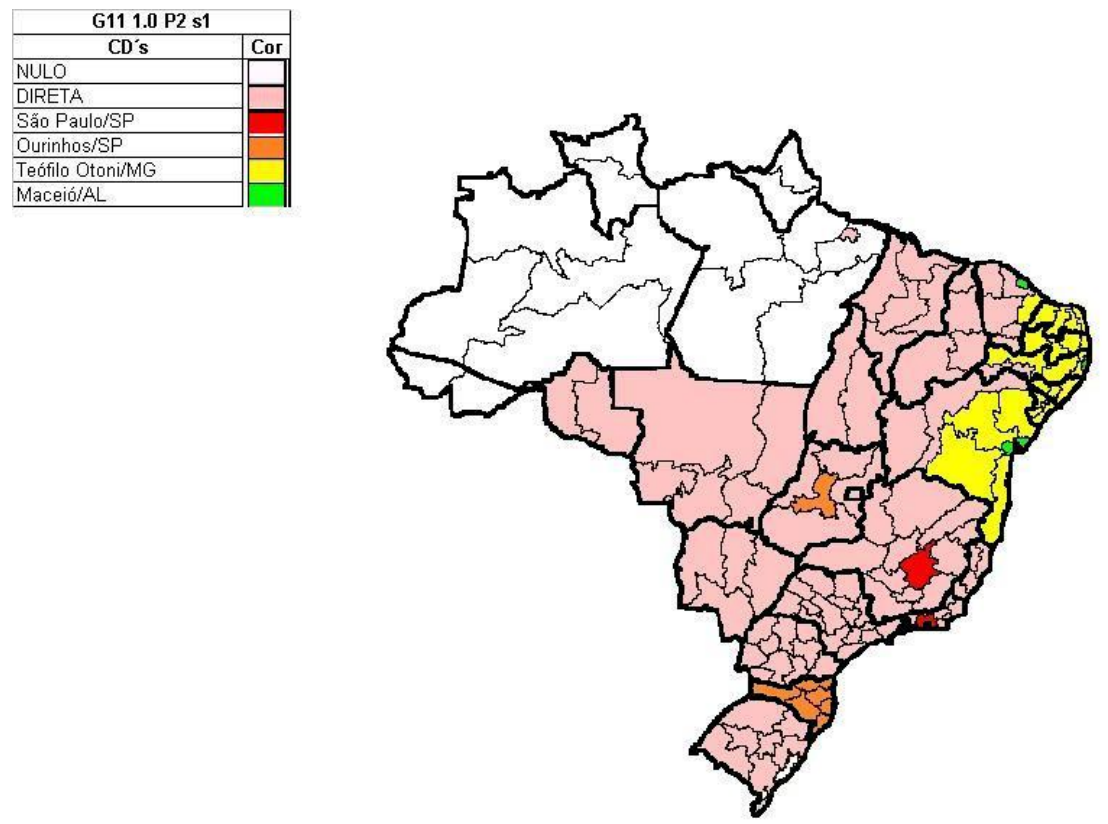

Figura 4.6. Áreas de influência de fábrica e CD’s, origem SC, sonegação assumida $100 \%$. 

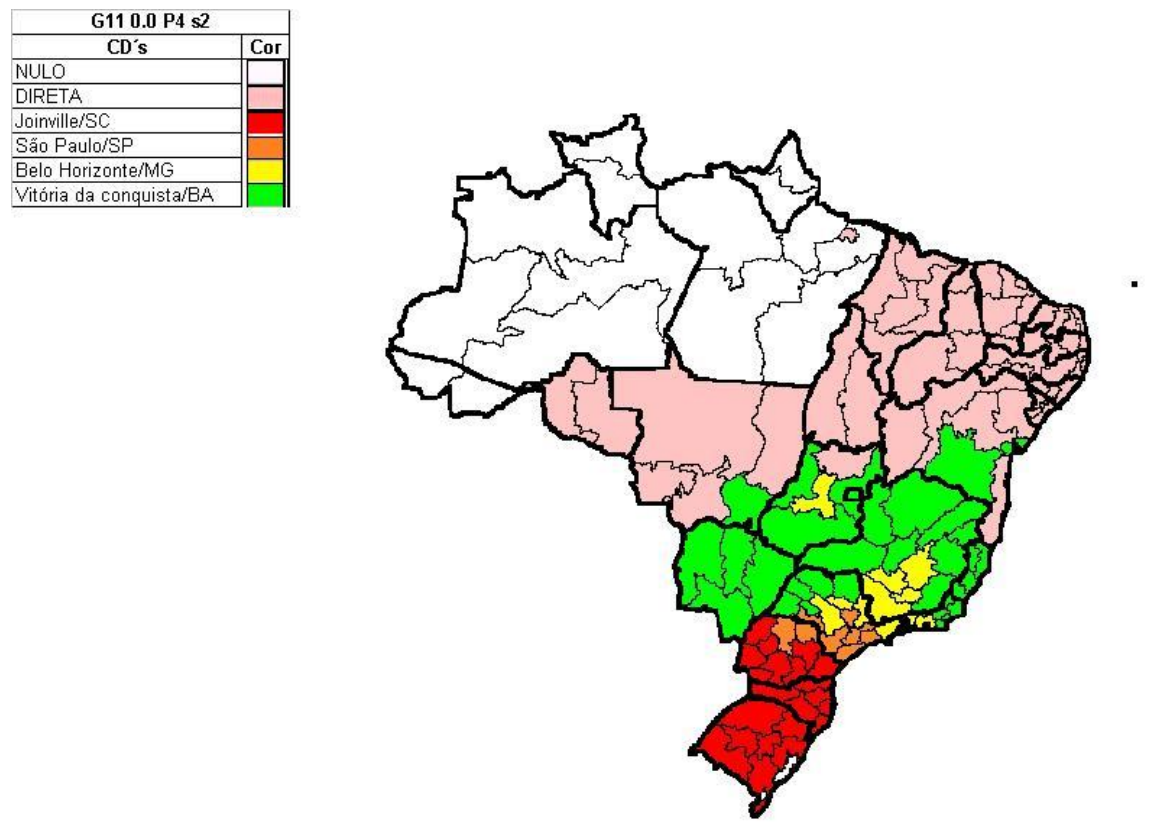

Figura 4.7. Áreas de influência de fábrica e CD’s, origem PE, sonegação assumida $0 \%$.
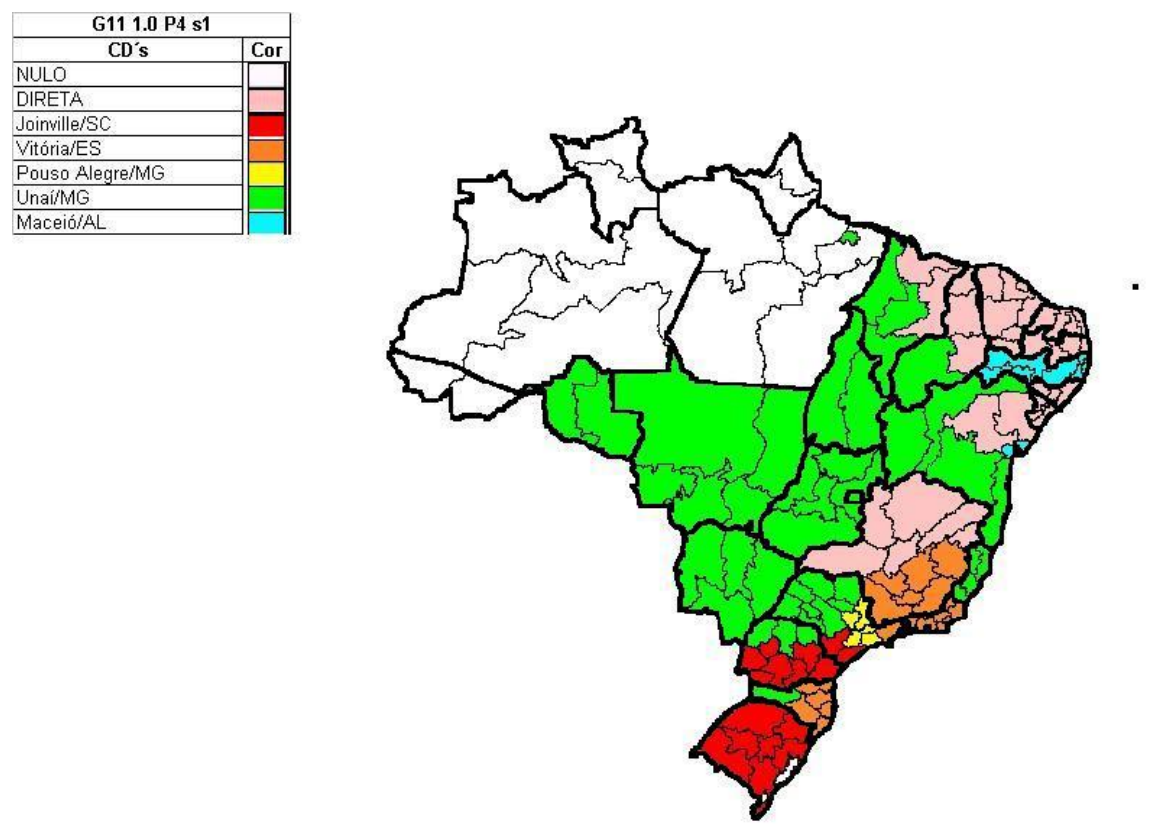

Figura 4.8. Áreas de influência de fábrica e CD’s, origem PE, sonegação assumida $100 \%$. 
Outra maneira agregada de comparar os cenários é se tabulando quais CD's estão abertos em cada cenário, além dos volumes entregues via $\mathrm{CD}$, conforme a Tabela 4.3 abaixo.

\begin{tabular}{|c|c|c|c|c|}
\hline \multirow{2}{*}{$\begin{array}{c}\text { Fábrica de } \\
\text { origem }\end{array}$} & \multicolumn{2}{|c|}{ CD's abertos } & \multicolumn{2}{|c|}{$\begin{array}{c}\text { Distribuição via CD } \\
\text { (toneladas) }\end{array}$} \\
\hline & 0\% soneg. assumida & $100 \%$ soneg. assumida & 0\% soneg. & $100 \%$ soneg. \\
\hline São Paulo/SP & \begin{tabular}{|l|} 
Porto Alegre/RS \\
Goiânia/GO \\
Vitória da Conquista/BA \\
Recife/PE \\
Juazeiro do Norte/CE
\end{tabular} & $\begin{array}{l}\text { Joinville/SC } \\
\text { Pouso Alegre/MG } \\
\text { Teófilo Otoni/MG } \\
\text { Aracaju/SE } \\
\text { Sousa/PB }\end{array}$ & $50.000,00$ & $130.510,53$ \\
\hline Joinville/SC & $\begin{array}{l}\text { Rio de Janeiro/RJ } \\
\text { Brasília/DF } \\
\text { Paulo Afonso/BA }\end{array}$ & $\begin{array}{l}\text { São Paulo/SP } \\
\text { Ourinhos/SP } \\
\text { Teófilo Otoni/MG } \\
\text { Maceió/AL }\end{array}$ & $40.000,00$ & $41.834,22$ \\
\hline Goiânia/GO & $\begin{array}{l}\text { Porto União/SC } \\
\text { São Paulo/SP } \\
\text { Franca/SP } \\
\text { Rio de Janeiro/RJ } \\
\text { Paulo Afonso/BA }\end{array}$ & $\begin{array}{l}\text { Porto União/SC } \\
\text { Pouso Alegre/MG } \\
\text { Franca/SP } \\
\text { Unaí/MG } \\
\text { Maceió/AL }\end{array}$ & $57.652,11$ & $67.760,22$ \\
\hline Recife/PE & \begin{tabular}{|l|} 
Joinville/SC \\
São Paulo/SP \\
Belo Horizonte/MG \\
Vitória da Conquista/BA
\end{tabular} & $\begin{array}{l}\text { Joinville/SC } \\
\text { Pouso Alegre/MG } \\
\text { Vitória/ES } \\
\text { Unaí/MG } \\
\text { Maceió/AL }\end{array}$ & $35.031,86$ & $36.702,56$ \\
\hline
\end{tabular}

Tabela 4.3. Quadro resumo de depósitos e fluxo via CD's

Pesquisando-se a tabela, pode-se constatar que o caso da origem em São Paulo segue mais fortemente o padrão de Goiânia (maior volume via CD). Recife também o faz, mas em grau muito menor: afinal de contas, para atender os mercados mais distantes, já precisava abrir depósitos no Sul e Sudeste, mas tem muitas opções razoáveis do ponto de vista logístico (como atender a mesorregião Metropolitana do Rio a partir de um CD em Vitória); há o "turismo" já mencionado Recife-Maceió-Recife e a abertura do CD de Unaí para aproveitar a menor alíquota de MG para atender outras regiões. 
Há outras situações que parecem confrontar o senso comum de logística. É o que acontece com diversos fluxos originados em Joinville/SC, que também teve pequeno incremento relativo para atendimento via $\mathrm{CD}(4,5 \%)$.

Verificando-se a lista de seus CD's em operação na Tabela 4.2 pode-se perceber que o depósito de Brasília/DF foi fechado quando o índice assumido de sonegação no canal é $100 \%$. Analisando-se os resultados do cenário de $0 \%$ de sonegação em detalhe, constatou-se que ele atendia uma mesorregião classe 2 de nível de serviço (750 km), a Centro Goiano, que contém Goiânia. Pelo mapa da Figura 4.5, pode-se notar que este CD atende boa parte da metade Norte do país, incluindo Maranhão, Tocantins e Belém do Pará. Porém, ao se considerar o ICMS, existe um interessante tradeoff entre abrir um $\mathrm{CD}$ em Brasília/DF e entregar direto da fábrica para localidades fora do Sul/ Sudeste: é a diferença das alíquotas de 12\% (para mercadoria com origem em Brasília) e 7\% (origem Joinville) novamente. Assim, o depósito em Ourinhos/SP mata dois coelhos com uma cajadada: faz o "turismo" do ICMS para Santa Catarina e está suficientemente próximo do Centro Goiano para atender a restrição de distância máxima (nível de serviço).

A discussão acima mostra algumas das peculiaridades do problema e a dificuldade de se analisar o mesmo de forma agregada ou isolada, apesar dela ter sido facilitada por trabalhar-se com cenários puros, isto é, totalmente sem ou com sonegação. Além disso, a geografia afeta diferentemente as fábricas distantes dos maiores centros de consumo: as fábricas de Joinville e Recife tiveram o menor incremento porcentual no custo logístico para o cenário de $100 \%$ de sonegação. Existe também o fator de escala, que será abordado abaixo

No item seguinte, os resultados do problema básico, onde as quatro indústrias compartilham sua infraestrutura logística, estão apresentados. 


\subsection{Resultados do Cenário Básico Multiprodutos}

A discussão no item anterior mostra a importância de se ter uma visão geográfica para encontrar o "turismo" de produtos. Porém, algumas medidas agregadas auxiliam bastante a análise, se forem tomados os devidos cuidados. Um indicativo importante é o crescimento do volume de entregas via depósitos ao se considerar sonegação do ICMS no canal. Outro indicativo é a abertura de CD's em locais diferentes daqueles escolhidos no cenário puro sem sonegação (onde somente entram considerações logísticas), com conseqüente fechamento ou não dos CD’s originais.

Inicialmente pode-se verificar a ocorrência ou não de ganhos de escala no caso de se desconsiderar a sonegação na cadeia comercial, ou seja, índice de sonegação assumida igual a zero (Tabela 4.4).

\begin{tabular}{|l|r|r|r|r|}
\hline & \multicolumn{1}{|c|}{$\begin{array}{c}\text { Distribuição } \\
\text { Itens de custo }\end{array}$} & \multicolumn{1}{c|}{$\begin{array}{c}\text { Distribuição } \\
\text { independente }\end{array}$} & \multicolumn{2}{|c|}{ Ganho de Escala } \\
\cline { 4 - 5 } & conjunta $(\mathrm{R} \$)$ & Absoluto (R\$) & Relativo (\%) \\
\hline Custo Fixo CD & $6.348 .457,36$ & $5.314 .046,68$ & $1.034 .410,68$ & $16,3 \%$ \\
\hline Frete Transferência & $13.908 .122,50$ & $14.160 .144,81$ & $-252.022,31$ & $-1,8 \%$ \\
\hline Frete Distribuição & $33.878 .727,79$ & $32.846 .445,43$ & $1.032 .282,36$ & $3,0 \%$ \\
\hline Custo Variável CD. & $182.683,97$ & $170.000,00$ & $12.683,97$ & $6,9 \%$ \\
\hline Custo Logístico & $54.317 .991,62$ & $52.490 .636,92$ & $1.827 .354,70$ & $3,4 \%$ \\
\hline a Soma dos custos equivalentes das quatro distribuições isoladas do sub-item anterior. & \\
\hline
\end{tabular}

Tabela 4.4. Ganhos de Escala referentes à Distribuição Conjunta - sem sonegação.

Como era de se esperar, há economia de escala na estrutura de movimentação, ou seja, na rede de centros de distribuição. Há também pequena perda $(1,8 \%)$ na transferência e um ganho na distribuição (3\%). O ganho absoluto no custo fixo de CD’s é da mesma ordem do ganho no frete de distribuição. 


\begin{tabular}{|l|r|r|r|r|}
\hline & \multicolumn{1}{|c|}{$\begin{array}{c}\text { Distribuição } \\
\text { Itens de custo }\end{array}$} & \multicolumn{1}{c|}{$\begin{array}{c}\text { Distribuição } \\
\text { independente }\end{array}$} & \multicolumn{2}{|c|}{ Ganho de Escala } \\
\cline { 4 - 5 } & & conjunta $(\mathrm{R} \$)$ & Absoluto (R\$) & Relativo (\%) \\
\hline Custo Fixo CD & $9.452 .429,21$ & $6.916 .697,40$ & $2.535 .731,81$ & $26,8 \%$ \\
\hline Frete Transferência & $12.887 .324,48$ & $11.940 .629,52$ & $946.694,96$ & $7,3 \%$ \\
\hline Frete Distribuição & $40.287 .585,17$ & $40.724 .690,14$ & $-437.104,97$ & $-1,1 \%$ \\
\hline Custo Variável CD. & $276.807,53$ & $258.484,89$ & $18.322,64$ & $6,6 \%$ \\
\hline Custo Logístico & $62.904 .146,39$ & $59.840 .501,95$ & $3.063 .644,44$ & $4,9 \%$ \\
\hline${ }^{a}$ Soma dos custos equivalentes das quatro distribuições isoladas do sub-item anterior & \\
\hline
\end{tabular}

Tabela 4.5. Ganhos de escala referentes à Distribuição Conjunta - 100\% sonegação assumida.

Conforme pode ser visto na Tabela 4.5 , que é o caso de se assumir $100 \%$ de sonegação na cadeia de distribuição, as mesmas vantagens de escala se aplicam; como o volume via CD era maior, a economia final no custo logístico também ficou maior.

\begin{tabular}{|c|c|c|c|}
\hline \multirow{2}{*}{ Tipo de distribuição } & Fluxo de Entrega & \multicolumn{2}{|c|}{ Volume Movimentado (t) } \\
\cline { 3 - 4 } & & $0 \%$ soneg. assum. & $100 \%$ soneg. assum. \\
\hline \multirow{2}{*}{ Total das independentes } & Via CD & $182.683,97$ & $276.807,53$ \\
\cline { 2 - 4 } & Via fábrica & $411.233,31$ & $317.109,75$ \\
\hline \multirow{2}{*}{ Distribuição conjunta } & Via CD & $170.000,00$ & $258.484,89$ \\
\cline { 2 - 4 } & Via fábrica & $423.917,28$ & $335.432,39$ \\
\hline
\end{tabular}

Tabela 4.6. Volume movimentado nos cenários puros (distribuição independente e conjunta).

Como pode ser visto na Tabela 4.6, há uma redução no volume total via CD para a distribuição conjunta em ambos os cenários (sem e com sonegação na cadeia de distribuição) comparada com a distribuição isolada; houve também a consolidação de 13 para 11 localidades com CD’s no caso sem sonegação e de 12 para 9 locais, no outro. Os volumes médios por CD’s são de 14.053 t/ano e 15.455 t/ ano, o que gera um pequeno ganho de escala por consolidação, para os casos com $0 \%$ de sonegação assumida (mesma coluna da tabela). Para os casos com 100\% de sonegação, os volumes médios são de 23.067 t/ano para distribuição independente, e de 28.721 t/ano, para distribuição conjunta, também configurando um ganho por consolidação. 
Assim, essa economia de escala resulta da redução do número de CD’s e da consolidação dos mesmos.

O ganho líquido de escala foi de 3,4\% no caso sem sonegação assumida e 4,9\% no outro, principalmente pela diminuição de custos fixos de CD’s (Tabelas 4.5 e 4.6).

Vamos agora comparar os cenários com distribuição conjunta, para finalmente encontrar o impacto do ICMS nos custos logísticos do problema básico, conforme a Tabela 4.7 a seguir.

\begin{tabular}{|l|r|r|r|r|}
\hline \multirow{2}{*}{ Itens de custo } & \multicolumn{2}{|c|}{ Custos (R\$) } & \multicolumn{2}{c|}{ Ganho de Escala } \\
\cline { 2 - 5 } & \multicolumn{1}{|c}{$\mathbf{0 \%}$ sonegação } & $\mathbf{1 0 0 \%}$ sonegação & Absoluto (R\$) & Relativo (\%) \\
\hline Custo Fixo CD & $5.314 .046,68$ & $6.916 .697,40$ & $-1.602 .650,72$ & $-30,2 \%$ \\
\hline Frete Transferência & $14.160 .144,81$ & $11.940 .629,52$ & $2.219 .515,29$ & $15,7 \%$ \\
\hline Frete Distribuição & $32.846 .445,43$ & $40.724 .690,14$ & $-7.878 .244,71$ & $-24,0 \%$ \\
\hline Custo Variável CD. & $170.000,00$ & $258.484,89$ & $-88.484,89$ & $-52,0 \%$ \\
\hline Custo Logístico & $52.490 .636,92$ & $59.840 .501,95$ & $-7.349 .865,03$ & $-14,0 \%$ \\
\hline Débito de ICMS & $204.091 .023,75$ & $161.852 .550,25$ & $42.238 .473,50$ & $20,7 \%$ \\
\hline CUSTO TOTAL & $256.581 .660,67$ & $221.693 .052,20$ & $34.888 .608,47$ & $13,6 \%$ \\
\hline
\end{tabular}

Tabela 4.7. Comparação dos cenários $0 \%$ e $100 \%$ de sonegação assumida para problema base (preço $R \$ 2.500 / t)$.

Pode-se então perceber as contrapartidas, pois temos um aumento de $14 \%$ nos custos logísticos para obter uma redução de 20,7\% nos débitos de ICMS, com uma redução no custo total de 13,6\%. O ICMS é evidentemente preponderante (como nos cenários isolados).

Uma comparação gráfica auxilia a enxergar a proporção entre essas diversas medidas (vide Figura 4.9). 


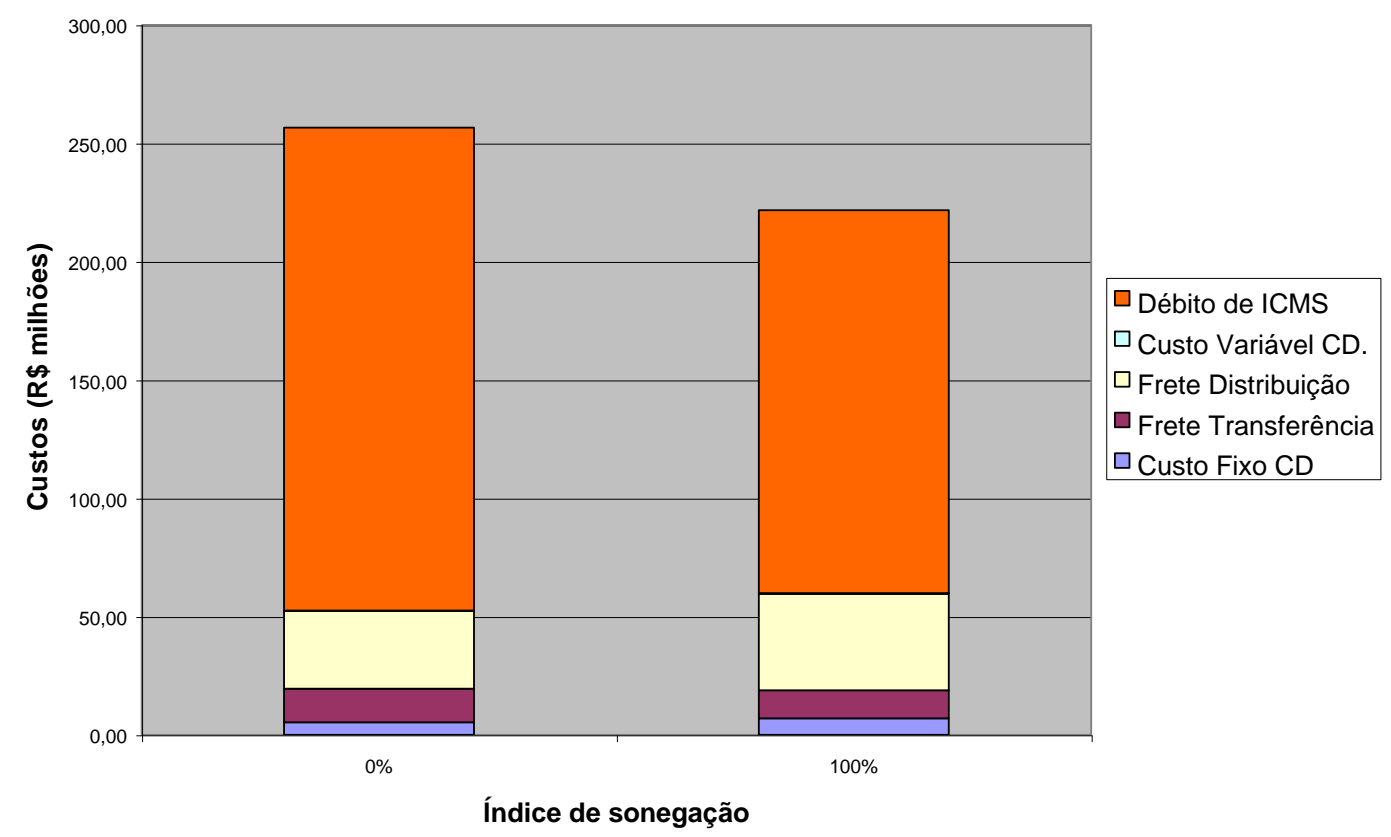

Figura 4.9. Comparação entre cenários com $0 \%$ e $100 \%$ de sonegação assumida, problema base.

Olhando a figura, o débito do ICMS parece se agigantar sobre os custos logísticos e o ganho ao se considerar o primeiro fica bem destacado. Vale a pena, neste ponto, lembrar que está se modelando apenas o débito do ICMS (pois é do ganho no mesmo que se pode avaliar os tradeoffs adequados); o recolhimento do tributo pelas indústrias seria consideravelmente menor, pois ainda têm-se os créditos referente às matérias-primas (que é uma constante e, portanto, não afeta a otimização).

Os mapas das Figuras 4.10 a 4.17 mostram as áreas de influência de cada origem, conforme o índice de sonegação assumida como praticada pelo canal.

Os exemplos que ocorrem seguem o mesmo padrão visto para a distribuição individual, com CD's abertos para "turismo" (como Pouso Alegre abasteceno São Paulo na Figura 4.11, ou Maceió entregando em Recife, na Figura 4.17) ou maior entrega direta de fábricas do Sudeste (Joinville abastecendo diretamente Estados do Norte, Figura 4.13) e Unaí servindo como "transbordo de ICMS" para produtos de Recife e Goiânia (Figuras 4.15 e 4.17). 

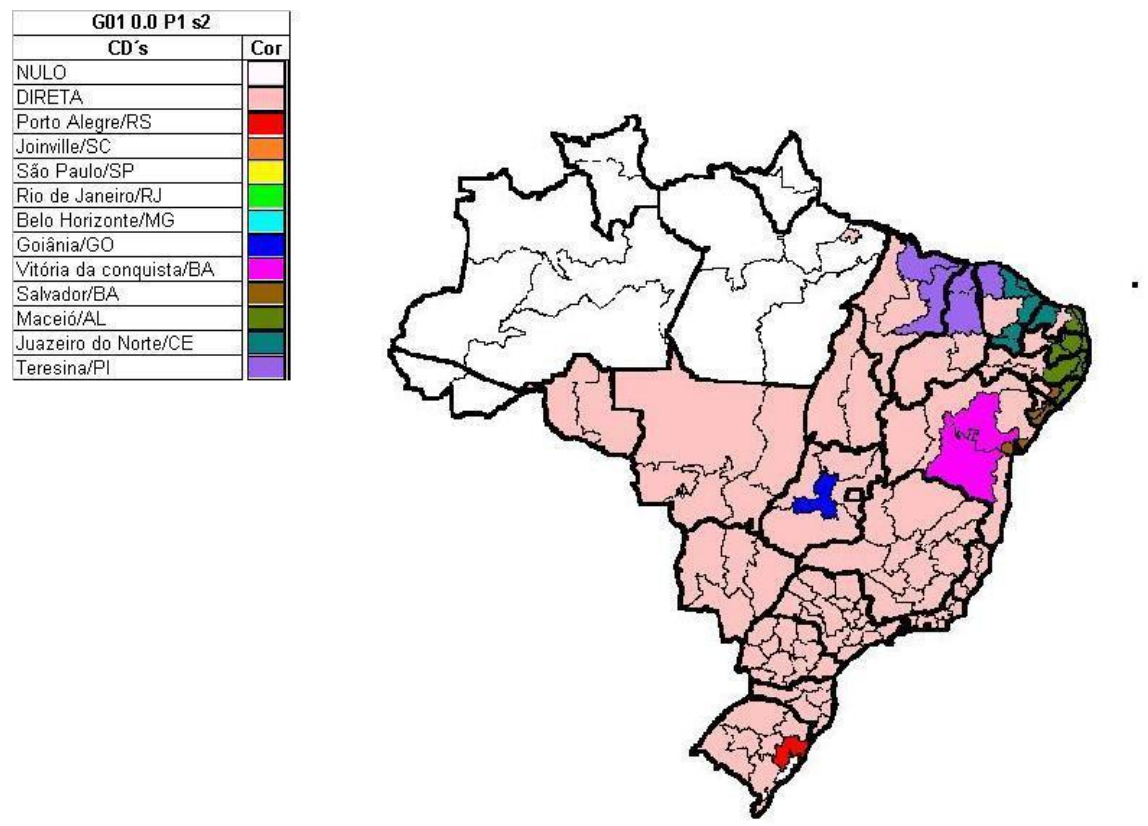

Figura 4.10. Áreas de influência, produto origem SP, $0 \%$ sonegação assumida.
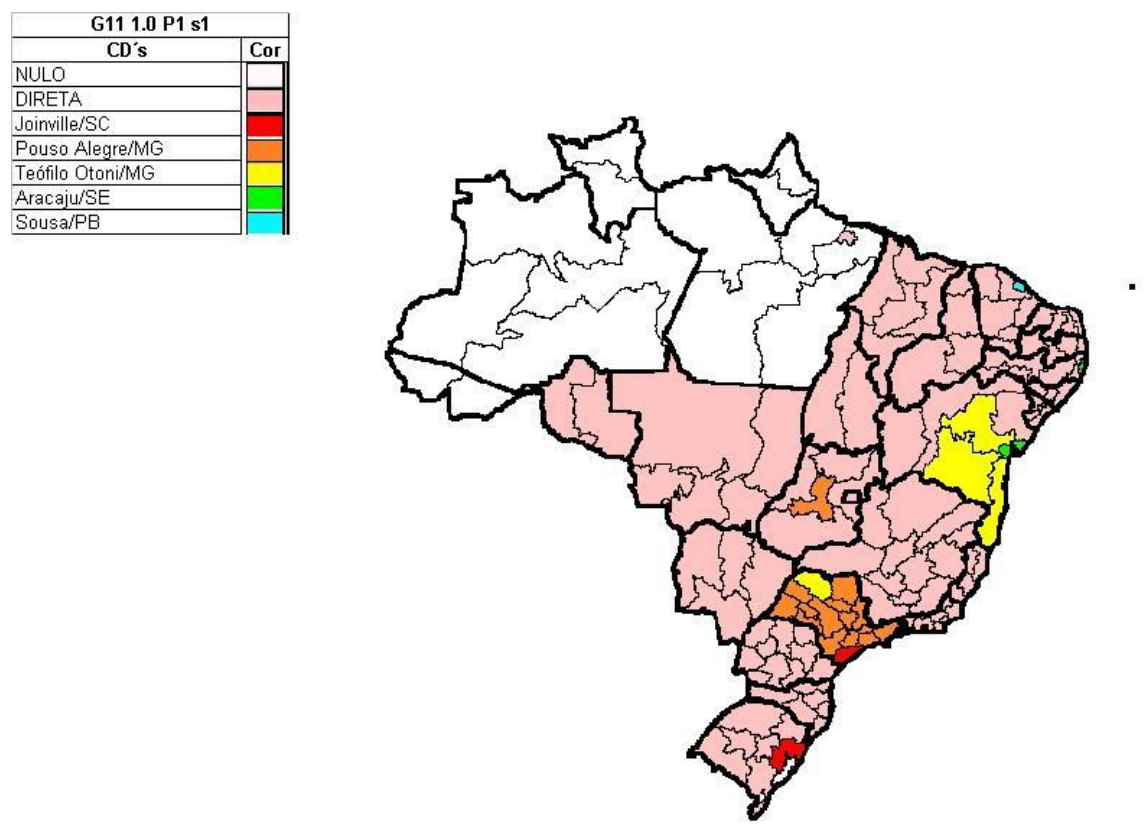

Figura 4.11. Áreas de influência, produto origem SP, $100 \%$ sonegação assumida 

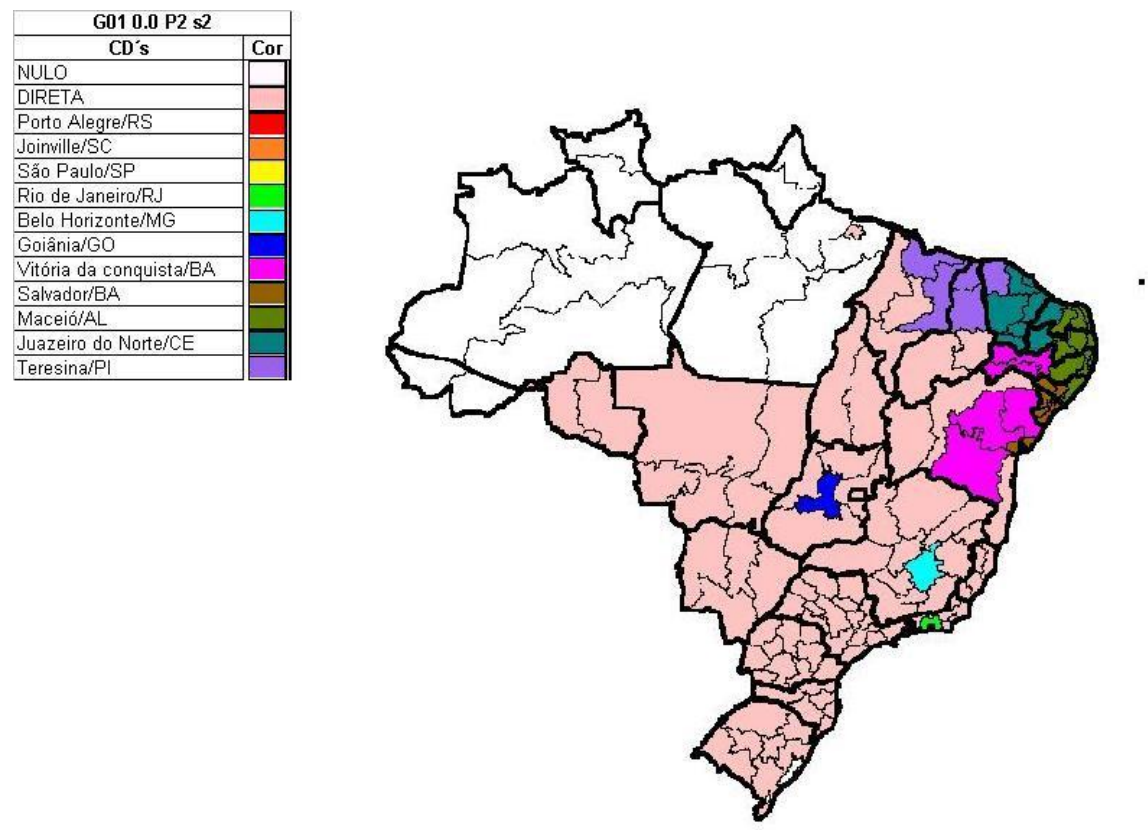

Figura 4.12. Áreas de influência, produto origem SC, $0 \%$ sonegação assumida.
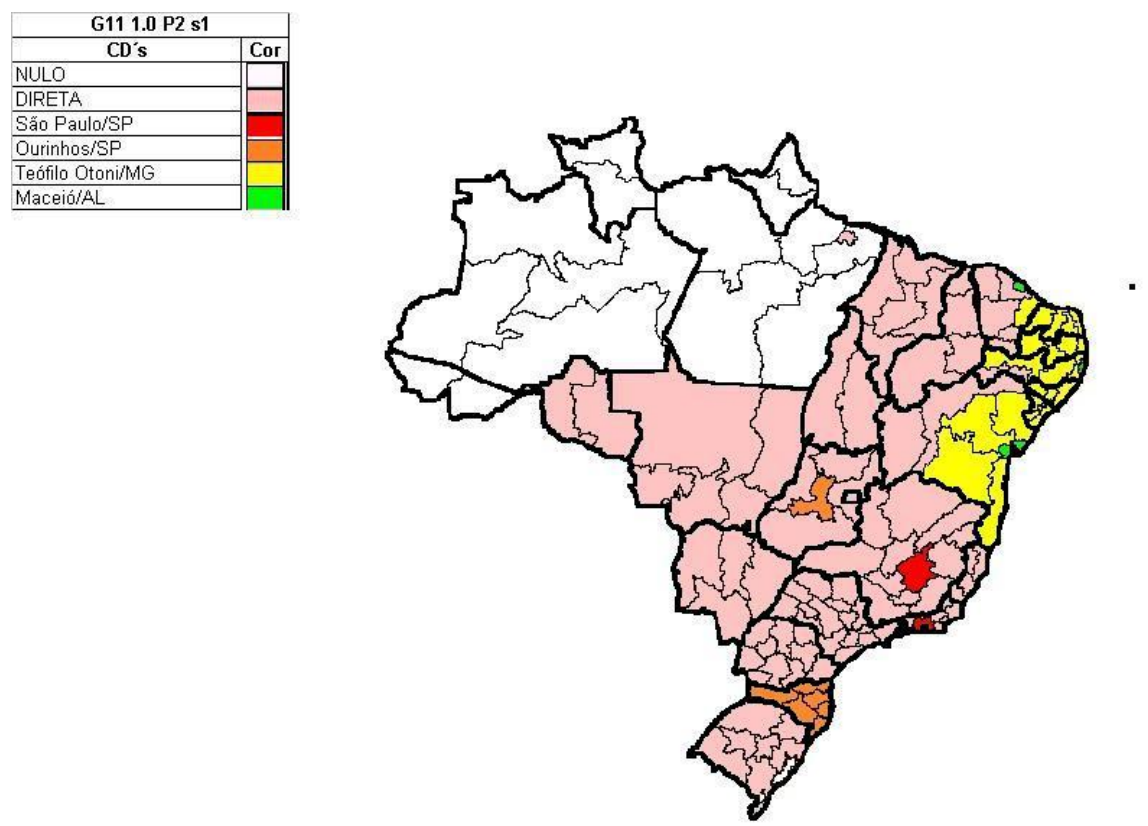

Figura 4.13. Áreas de influência, produto origem SC, $100 \%$ sonegação assumida. 

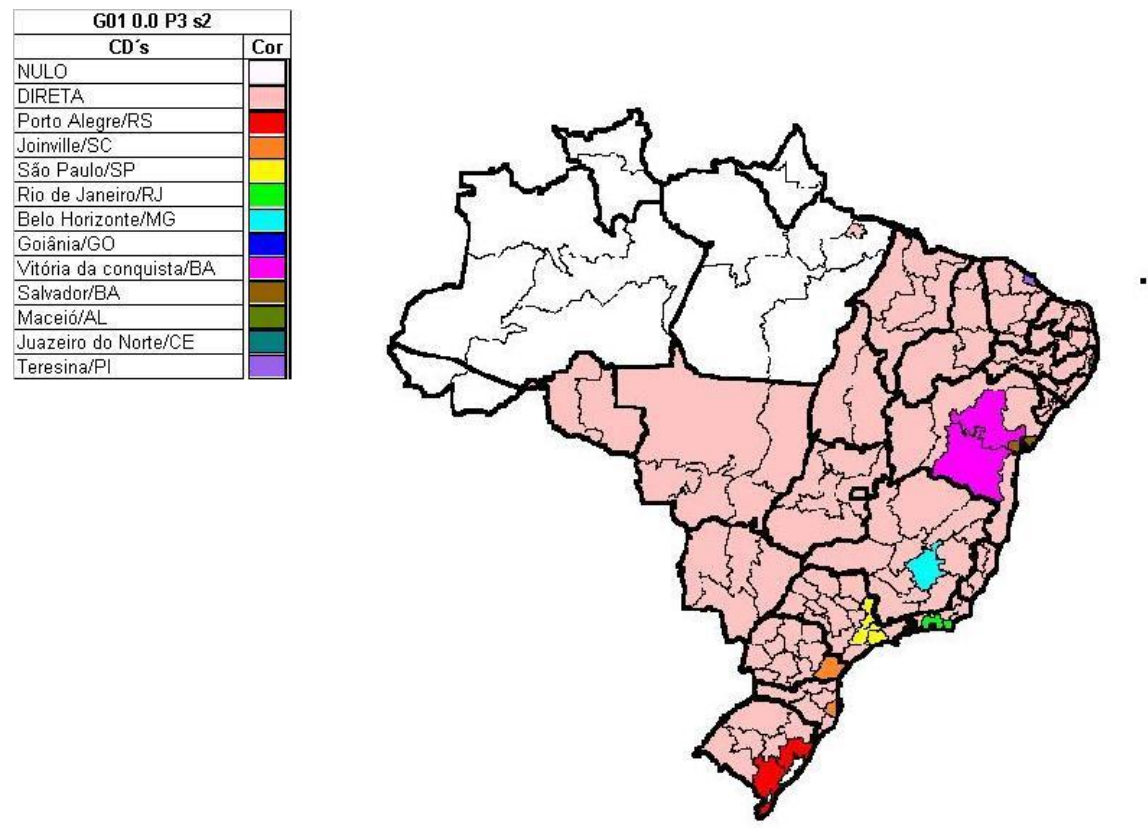

Figura 4.14. Áreas de influência, produto origem GO, $0 \%$ sonegação assumida.
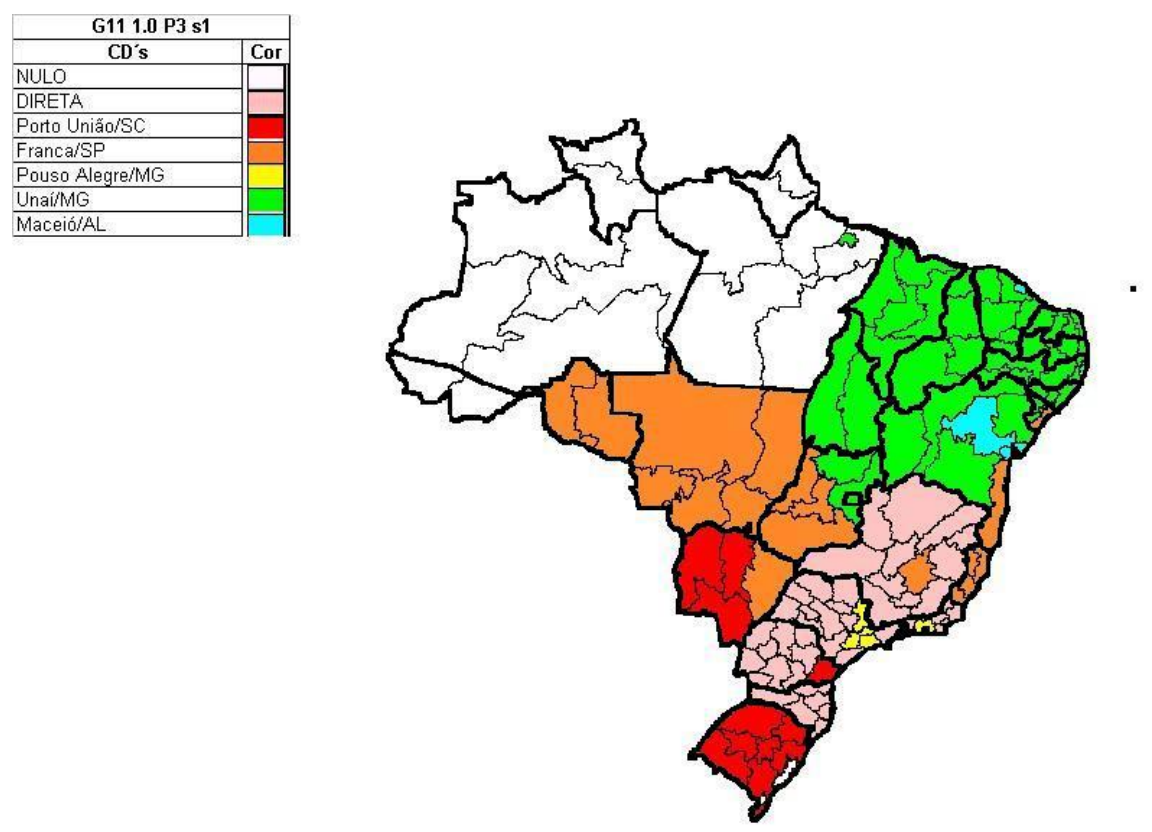

Figura 4.15. Áreas de influência, produto origem GO, 100\% sonegação assumida. 

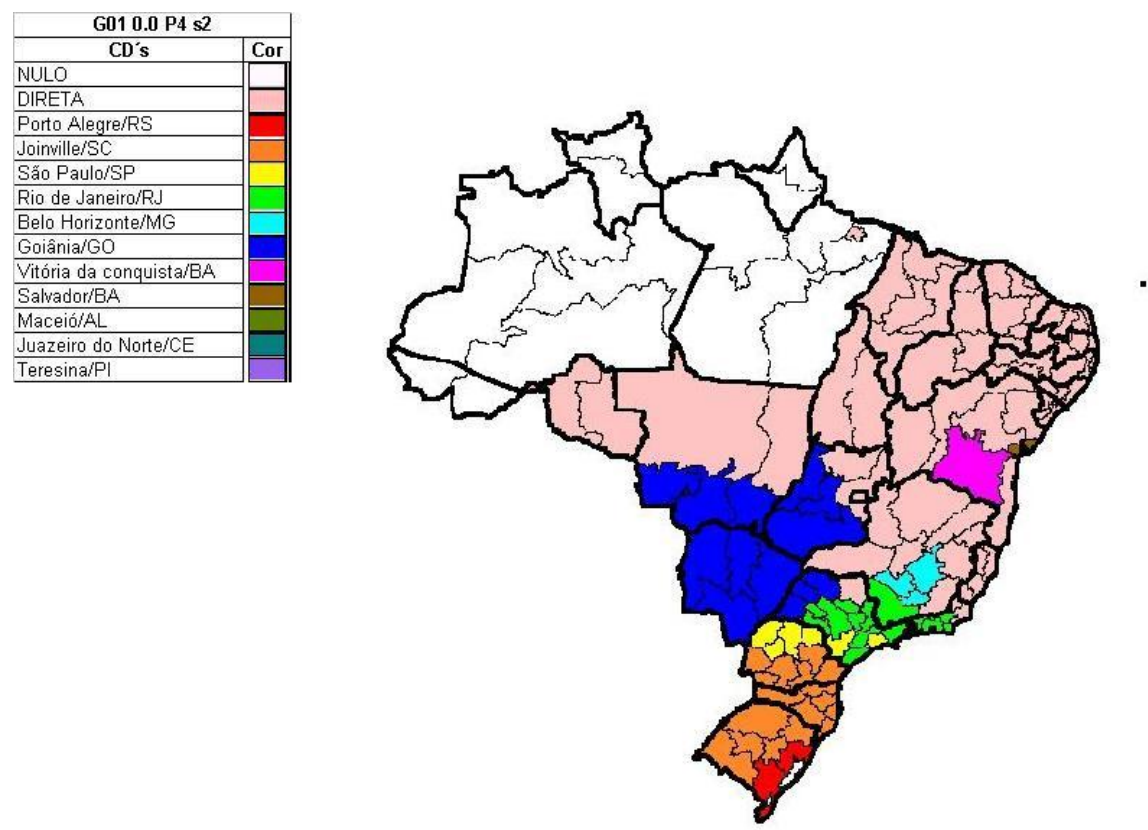

Figura 4.16. Áreas de influência, produto origem PE, $0 \%$ sonegação assumida.
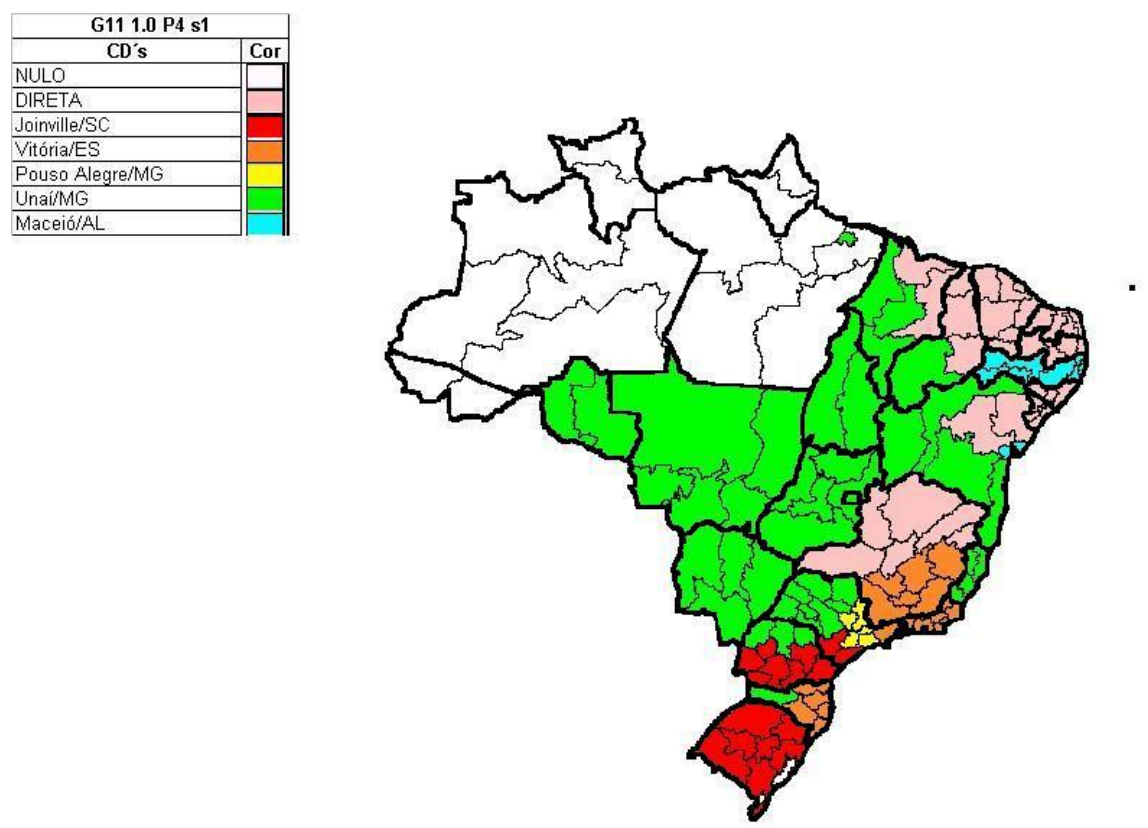

Figura 4.17. Áreas de influência, produto origem PE, $100 \%$ sonegação assumida. 
Os cenários puros facilitam focalizar a diferença entre decisões logísticas tomadas sem e com a influência de sonegação do ICMS por parte dos clientes, tornando mais claro o impacto deste último no projeto de redes físicas de distribuição. Entretanto, tais hipóteses de comportamento são bastante implausíveis na prática: o índice de sonegação real deve estar entre um extremo e outro. Por isso, fez-se uma análise de sensibilidade em que se variou o índice de sonegação de 20 em $20 \%$, conforme detalhado no item seguinte.

\subsection{Análise de sensibilidade}

Aqui serão reportadas as variações em dois parâmetros, índice de sonegação e preço médio da mercadoria. Elas são importantes para a compreensão dos tradeoffs em questão.

\subsubsection{Variação de índice de sonegação para o cenário básico}

Para avaliar como a rede de distribuição ótima se altera à medida que o índice de sonegação vai aumentando, foram processados vários cenários adicionais no problema básico. Foi-se incrementando o índice de sonegação em proporções constantes de $20 \%$, obtendo-se os custos discriminados na Tabela 4.8.

\begin{tabular}{|c|c|c|c|c|c|c|}
\hline \multirow[b]{2}{*}{ Custos } & \multicolumn{6}{|c|}{ Índice de sonegação } \\
\hline & $0 \%$ & $20 \%$ & $40 \%$ & $60 \%$ & $80 \%$ & $100 \%$ \\
\hline Fixo CD & 5,31 & 5,83 & 6,01 & 6,42 & 6,30 & 6,92 \\
\hline Frete Transferência & 14,16 & 14,16 & 13,06 & 12,18 & 11,94 & 11,94 \\
\hline Frete Distribuição & 32,85 & 34,14 & 36,54 & 38,52 & 40,12 & 40,72 \\
\hline Variável CD & 0,17 & 0,20 & 0,21 & 0,22 & 0,24 & 0,26 \\
\hline Logístico & 52,49 & 54,32 & 55,81 & 57,34 & 58,60 & 59,84 \\
\hline Débito ICMS & 204,09 & 189,31 & 182,99 & 175,49 & 166,28 & 161,85 \\
\hline TOTAL & 256,58 & 243,63 & 238,80 & 232,83 & 224,88 & 221,69 \\
\hline
\end{tabular}

Tabela 4.8. Custos para cenário-base (preço médio $R$ \$ 2.500/t) - valores em $R$ \$ milhões 
Como era de se esperar, os custos logísticos vão aumentando e o débito do ICMS vai diminuindo; há uma tendência média crescente nos custos fixos de CD (fora a pausa entre 60 e $80 \%$ ); o custo variável de CD só aumenta, indicando que o volume via CD só aumenta. O gráfico de barras na Figura 4.18 auxilia a enxergar as tendências gerais e a proporcionalidade dos custos componentes.

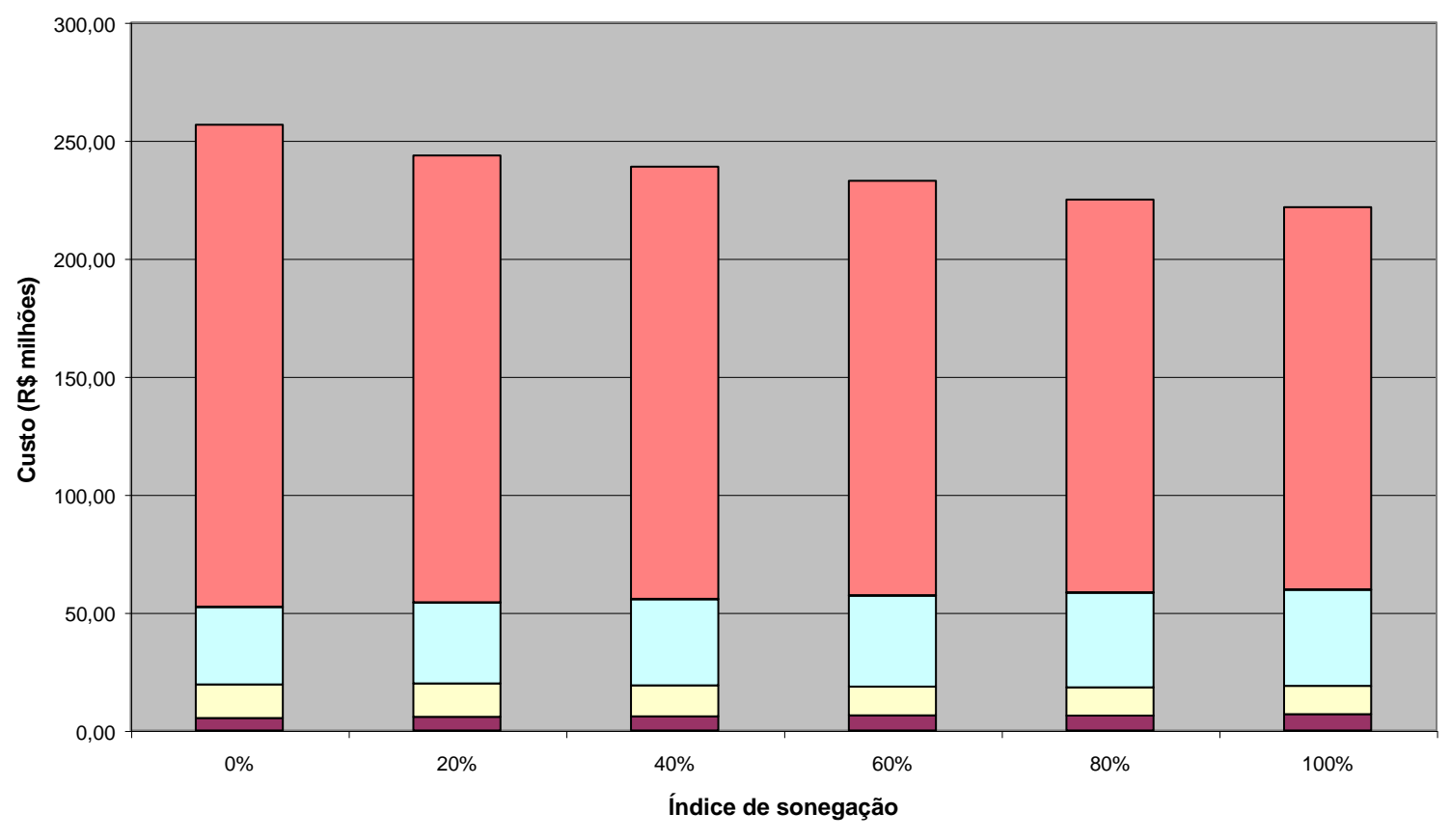

$\square$ Fixo CD $\square$ Frete Transf. $\square$ Frete Distr. $\square$ Var. CD $\square$ Deb. ICMS

Figura 4.18. Crescimento de custos em função do índice de sonegação (cenário base)

Para observar os tradeoffs entre custos logísticos e o débito de ICMS, foi preparada a Figura 4.19. Nota-se claramente o comportamento antagônico das curvas, indicando a contrapartida entre estes dois custos e como a variação marginal é claramente favorável ao débito de ICMS (diminui muito mais rápido do que o custo logístico cresce). 


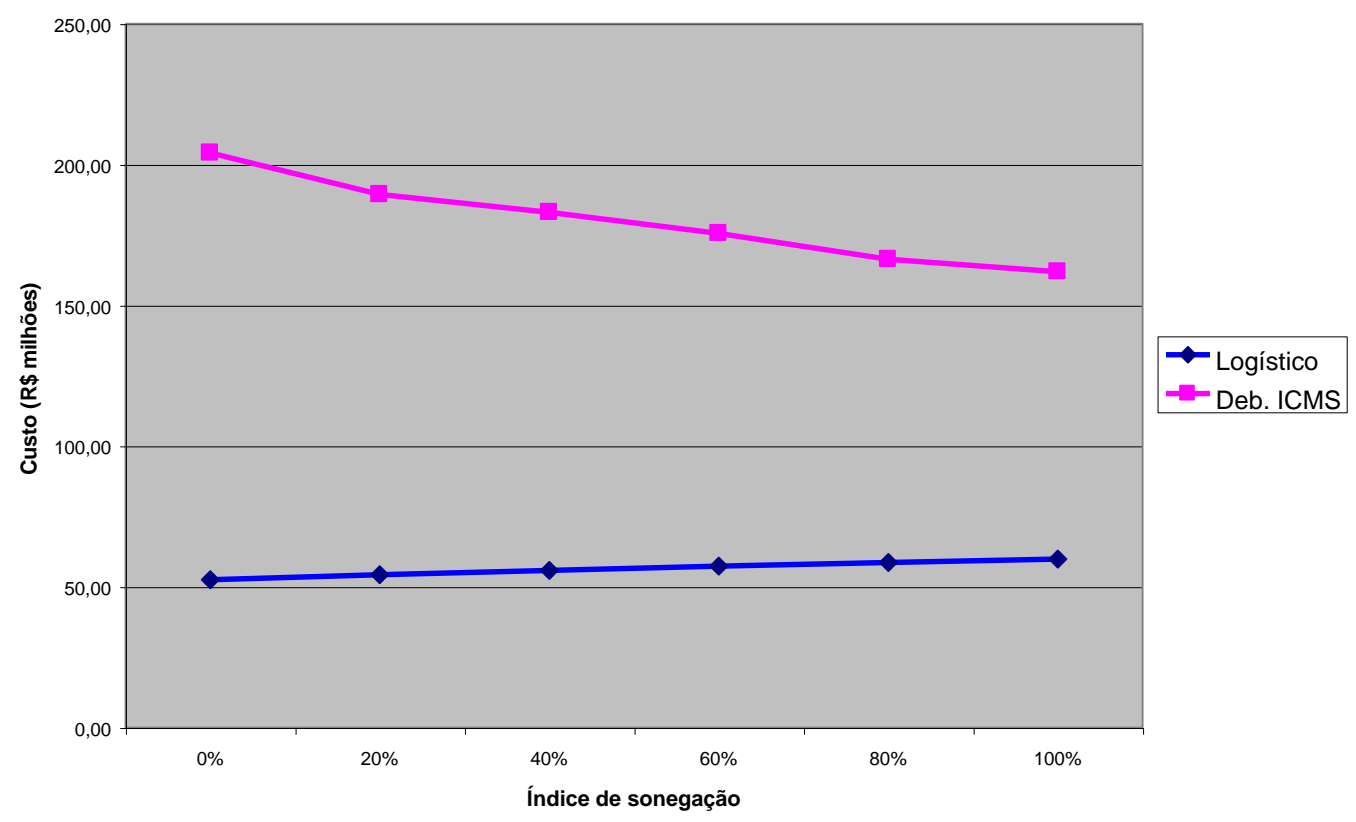

Figura 4.19. Curvas de custos logísticos e ICMS no problema base, variando-se o índice de sonegação.

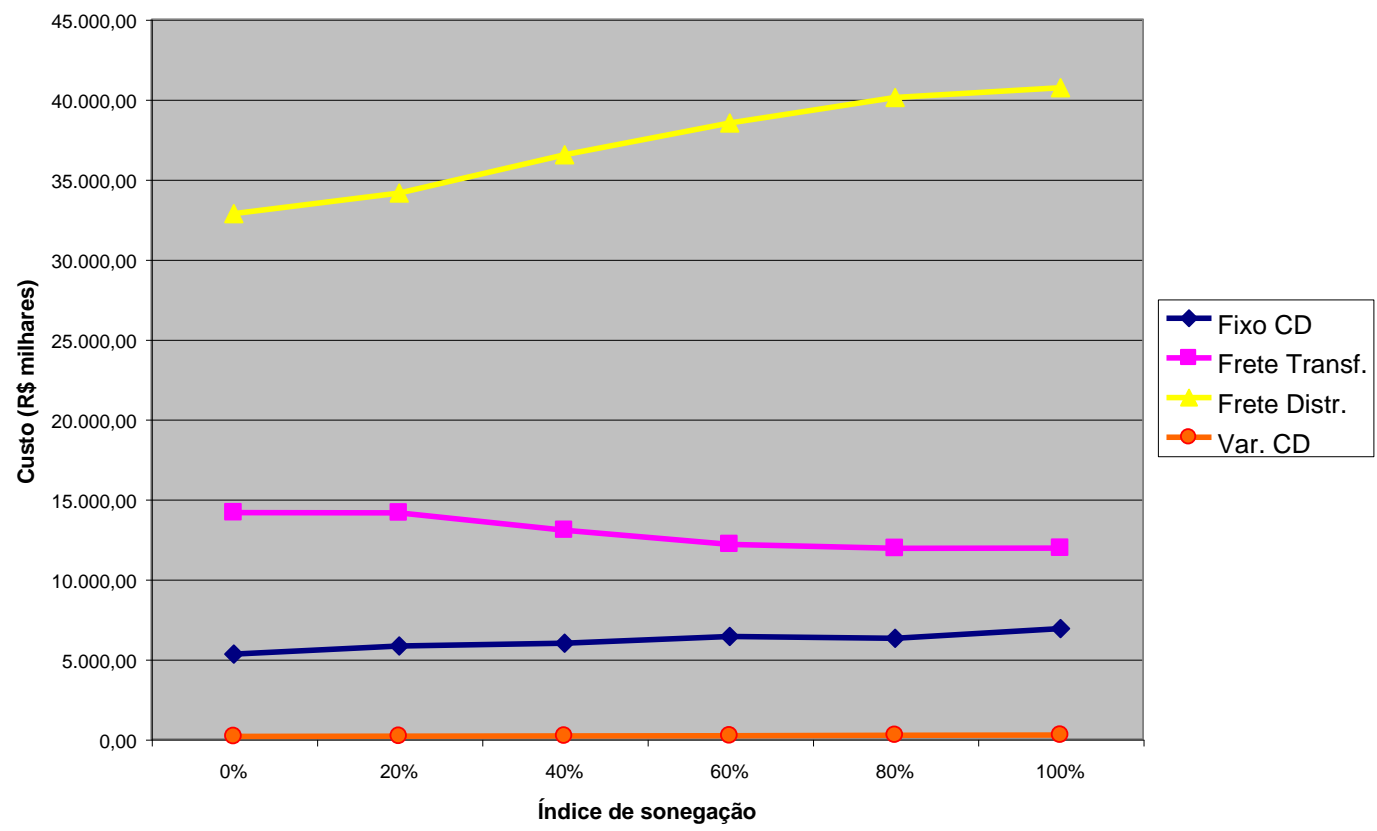

Figura 4.20. Componentes de custo logístico para cenário-base. 
A Figura 4.20 mostra o comportamento dos diversos componentes do custo logístico. É interessante reparar que o custo logístico varia lentamente, enquanto certos componentes têm variações relativas maiores, como o frete de distribuição.

Tanto a tabela quanto as figuras são pouco elucidativas com relação ao que está ocorrendo com a logística, fora os custos. Como foi visto anteriormente, o uso de mapas é muito importante para se entender os novos fluxos que ocorrem. Entretanto, devido à multiplicidade de dimensões a analisar, seriam necessários mais 4 x 4 x $2=$ 32 mapas, correspondentes às dimensões de variação do índice (quatro referentes à variação no índice entre $20 \%$ e $80 \%$; não há necessidade dos mapas dos cenários puros, que estão no item anterior), dos produtos ou fábricas (4 origens) e se é o fluxo destinado aos clientes sonegadores ou não-sonegadores (2 tipos). Assim, para evitar essa profusão de mapas (todos os mapas de análise de sensibilidade deste subitem estão no Anexo D), vai-se trabalhar com uma tabela resumo. Se necessário, um ou outro mapa será colocado para facilitar a discussão.

Essa tabela resumo funciona como um mapa da abertura e fechamento de instalações no sistema de distribuição. Apenas as localidades escolhidas em algum dos cenários componentes aparecem na lista de CD’s. Cores diferentes foram usadas para mostrar a robustez do sítio ao se variar o nível de sonegação: olhando-se sempre da esquerda para a direita (sonegação crescente), o amarelo mostra a persistência do local original (cenário sem sonegação, ou índice igual a zero), com sua capacidade inalterada; a cor laranja mostra quando o sítio ainda persistindo, mas com capacidade diminuída; o violeta significa o fechamento ou abertura de depósito, ou seja, uma mudança na rede ocasionada pelo ICMS (vide Tabela 4.9). 


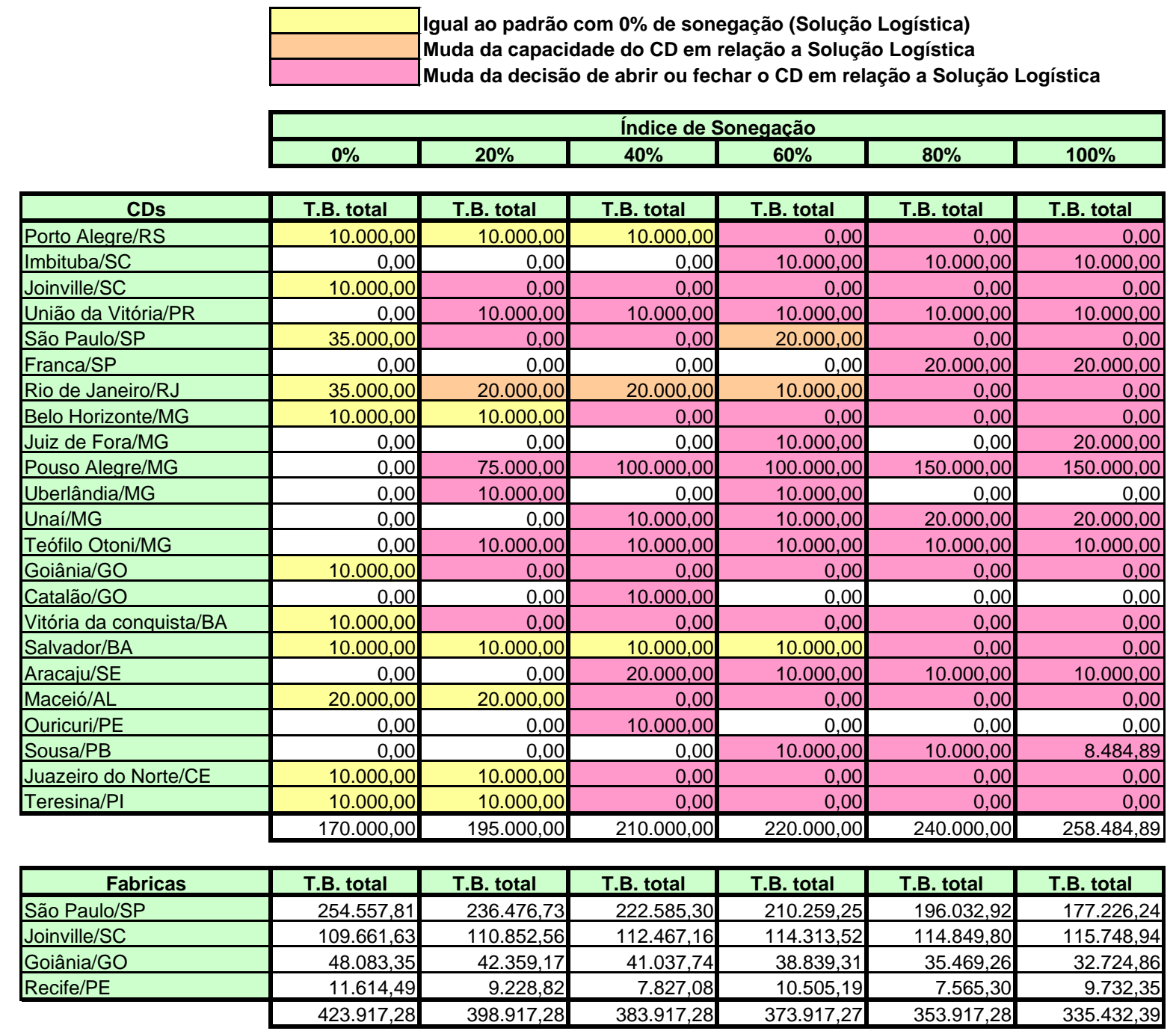

OBS: CD's não listados não aparecem em nenhum dos cenários

Tabela 4.9. Mapa de abertura-fechamento de CD’s no cenário-base (preço $R$ \$ 2.500/t)

Olhando-se a Tabela 4.9, pode-se perceber que, já no primeiro nível de sonegação (20\%), há uma significativa mudança na configuração de CD's: os depósitos de Joinville, São Paulo, Goiânia e Vitória da Conquista/BA são fechados e abertos substitutos em locais alternativos para o "turismo" de mercadorias (depósitos aqui cognominados de "turísticos"; eles são, respectivamente, União da Vitória/PR, Pouso Alegre/MG, Uberlândia/MG, Teófilo Otoni/MG). Dos CD’s ditos "logísticos" (ou seja, da solução sem ICMS, em que apenas aspectos logísticos influem), Porto Alegre, Salvador e Rio da Janeiro resistem por mais tempo, embora este último vá perdendo volume paulatinamente. Três dos armazéns "turísticos" abertos ficam em Pouso Alegre, Uberlândia, Teófilo Otoni (todos em MG), atendendo os clientes dos 
três últimos CD's fechados; União da Vitória/PR faz “turismo" Joinville-União da Vitória-Santa Catarina para os clientes sonegadores deste último Estado e do Rio Grande do Sul também. Os fluxos são complicados, por isso vai-se colocar apenas os mapas com produtos originados em São Paulo, pois pode-se perceber claramente o "turismo" acontecendo com as mercadorias que voltam via Pouso Alegre (Figuras 4.21 e 4.22). Reparar que, com exceção das mesorregiões do Sul da Bahia (atendidas pelo CD de Teófilo Otoni/MG), todas as outras recebem produtos de duas origens diferentes (como o Centro Goiano, abastecido por Pouso Alegre e Uberlândia).

Voltando-se à Tabela 4.9, é dificílimo se detalhar os porquês de todos as decisões pois elas são complexas, considerando simultaneamente todos os tradeoffs modelados no problema. Por isso, a variação dos resultados não é linear; pequenas alterações em determinados parâmetros fazem a solução virar de "ponta-cabeça". Esse problema é bem conhecido na literatura de programação linear (Brown; Dell; Wood, 1997) e é chamado de falta de persistência da solução. Características de persistência são importantes em sistemas de apoio à decisão processados em períodos regulares e devem ser implementadas nos mesmos. Para este estudo, entretanto, esta característica não é fundamental e foi desconsiderada na modelagem.

Um exemplo é a reabertura do depósito de São Paulo quando o índice de sonegação é $60 \%$; ao se analisar os fluxos em detalhe, viu-se que ele passa a ter um importante papel no "turismo", abastecendo as mesorregiões Metropolitanas de Belo Horizonte e Curitiba com produtos de Joinville, Goiânia e Recife (7.600 t/ano, ou 38\% de sua capacidade instalada), substituindo os CD's de "turismo" para essa regiões, que eram Rio de Janeiro/RJ e Pouso Alegre/MG (reparar que o volume do último se mantém em 100.000 t/ano e o penúltimo diminui de 20.000 t/ano para 10.000 t/ano). Basta aumentar o índice de sonegação para $80 \%$ para o CD São Paulo fechar e Pouso Alegre ir abruptamente para 150.000 t/ano. 

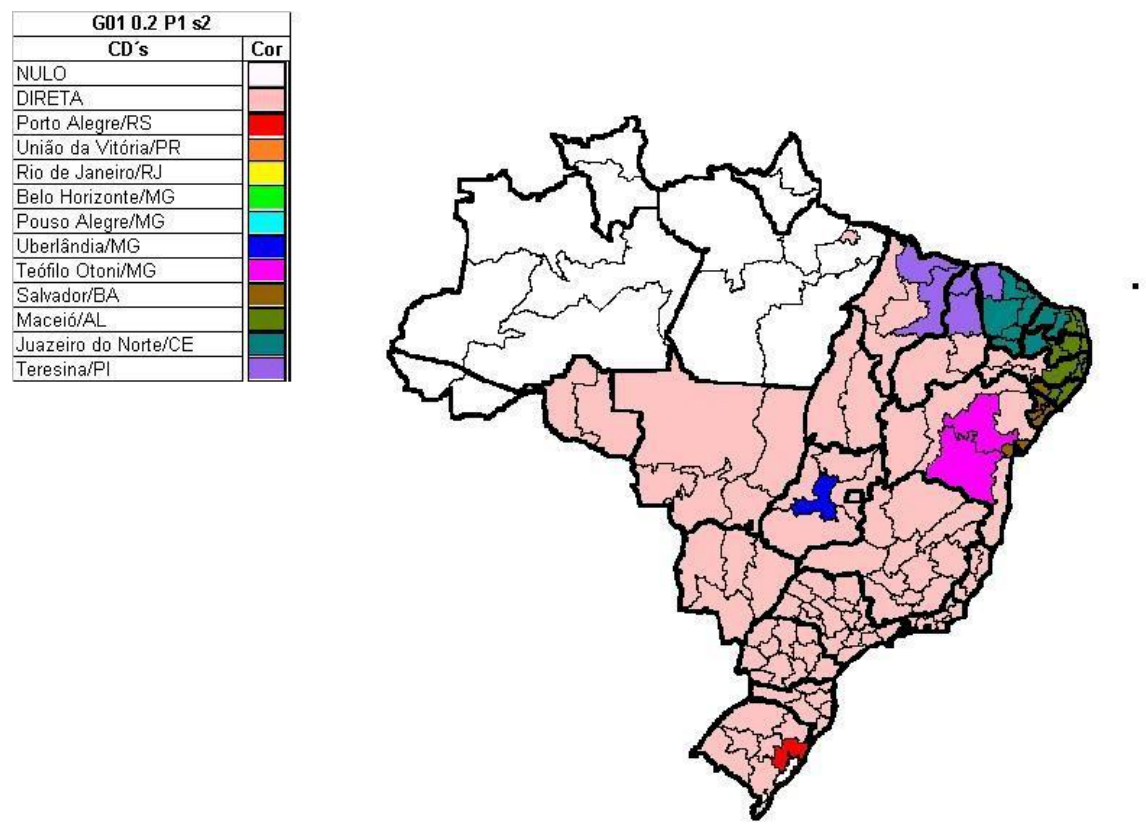

Figura 4.21. Áreas de influência, produto origem SP, $20 \%$ sonegação assumida, clientes querem crédito de ICMS ( $\mathrm{s}=2)$.
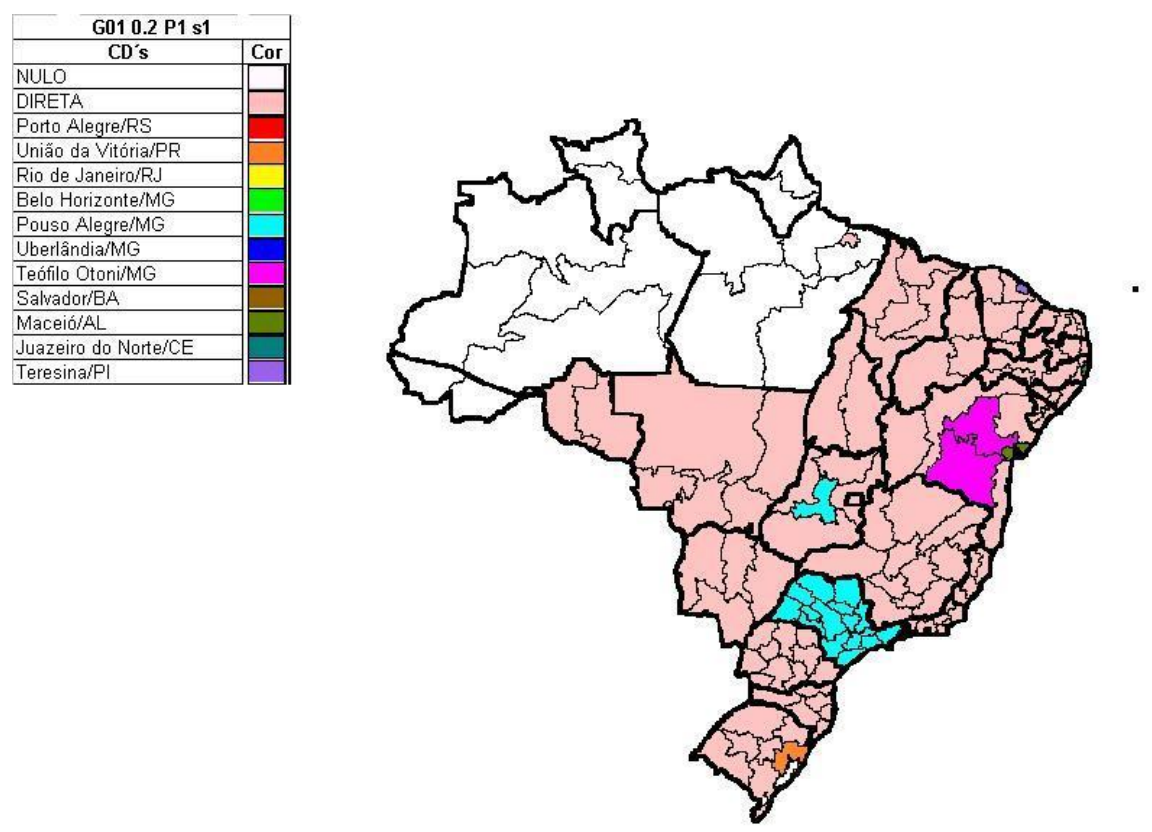

Figura 4.22. Áreas de influência, produto origem SP, $20 \%$ sonegação assumida, cliente indiferentes ao crédito de ICMS (sonegadores potenciais, $s=1$ ). 
Olhando-se a tabela 4.9 da esquerda para a direita (aumentando a sonegação), Salvador/BA é um local bastante robusto pois mantém um depósito de 10.000 t/ano até o nível de $60 \%$ de sonegação, sempre abastecendo apenas clientes que não sonegam $(s=2)$. O CD Rio de Janeiro vai perdendo fluxo à medida que a sonegação cresce; quando o índice é de $60 \%$, apenas $12 \%$ de seu fluxo é direcionado para clientes indiferentes ao crédito (sonegadores potenciais).

Por outro lado, temos os CD's robustos do ponto de vista de "turismo". Para encontrá-los, é mais fácil olhar a tabela da direita para a esquerda. Temos União da Vitória/PR, Unaí/MG, Teófilo Otoni/MG, Aracaju/SE e o emblemático caso de Pouso Alegre/MG, que atende os mercados paulista e carioca. Ao ser aberto no índice de $20 \%$, ele começa já com metade de sua capacidade voltada para o “turismo". Aliás, o Estado de Minas Gerais tem diversas vantagens geográficas (é central e tem municípios próximos de grandes centros de demanda) e de ICMS, pois tem uma alíquota interestadual de 7\% para os Estados do Norte, Nordeste e CentroOeste. O "turismo" de Unaí (visto no item 4.2) do produto de Goiânia voltando para Goiás e Distrito Federal é exemplar: consegue ser mais competitivo que um “turismo" de Brasília/DF para Goiânia (pois a alíquota interestadual do DF é 12\%).

\subsubsection{Variação de preços médios para o cenário básico}

Viu-se que mesmo um baixo índice de sonegação tem grande influência na rede desenhada de CD's. Por que isto ocorre? Bem, ao considerar-se um preço médio de $\mathrm{R} \$ 2.500,00$ por tonelada, o "turismo" do ICMS pode economizar de 5\% a 11\% desse preço médio no débito do tributo. Em números absolutos, isto significa algo entre $\mathrm{R}$ \$ 125,00 e $\mathrm{R}$ \$ 275,00 a tonelada, equivalentes a fretes de distribuição de 1.300 e $3.300 \mathrm{~km}$, respectivamente! Para esse valor médio de mercadoria, o "turismo" pode ser um bom negócio.

Desta forma, foi realizada uma análise de sensibilidade, variando-se o preço médio em $1 / 4,1 / 2$ e 2 vezes o valor de $R \$ 2.500,00$, ou seja, $R \$ 625, R \$ 1.250$ e $R \$ 5.000$, 
respectivamente. Mantiveram-se os mesmos índices de sonegação, variando os mesmos entre 0 e $100 \%$, com incrementos de $20 \%$.

Os novos preços médios estão dentro da variação encontrada nos produtos aqui modelados, que ocorrem dentro de faixa de $\mathrm{R} \$ 600$ a $\mathrm{R} \$ 7.500$ por tonelada.

As tabelas resumo e gráficos com os custos componentes estão relacionados a seguir.

\begin{tabular}{|c|c|c|c|c|c|c|}
\hline & & \multicolumn{5}{|c|}{$\begin{array}{l}\text { Igual ao padrão com } 0 \% \text { de sonegação (Solução Logística) } \\
\text { Muda da capacidade do CD em relação a Solução Logística } \\
\text { Muda da decisão de abrir ou fechar o CD em relação a Solução Logística }\end{array}$} \\
\hline & \multicolumn{6}{|c|}{ Índice de Sonegação } \\
\hline & $0 \%$ & $20 \%$ & $40 \%$ & $60 \%$ & $80 \%$ & $100 \%$ \\
\hline CDs & T.B. total & T.B. total & T.B. total & T.B. total & T.B. total & T.B. total \\
\hline Porto Alegre/RS & $10.000,00$ & $10.000,00$ & $10.000,00$ & 0,00 & 0,00 & 0,00 \\
\hline Joinville/SC & $10.000,00$ & $10.000,00$ & $10.000,00$ & $20.000,00$ & $20.000,00$ & $20.000,00$ \\
\hline São Paulo/SP & $35.000,00$ & $35.000,00$ & 0,00 & 0,00 & 0,00 & 0,00 \\
\hline Franca/SP & 0,00 & 0,00 & 0,00 & 0,00 & $10.000,00$ & $20.000,00$ \\
\hline Rio de Janeiro/RJ & $35.000,00$ & $20.000,00$ & $20.000,00$ & $10.000,00$ & 0,00 & 0,00 \\
\hline Belo Horizonte/MG & $10.000,00$ & $20.000,00$ & $10.000,00$ & 0,00 & 0,00 & 0,00 \\
\hline Pouso Alegre/MG & 0,00 & 0,00 & $50.000,00$ & $75.000,00$ & $75.000,00$ & $75.000,00$ \\
\hline Uberaba/MG & 0,00 & $20.000,00$ & 0,00 & 0,00 & 0,00 & 0,00 \\
\hline Uberlândia/MG & 0,00 & 0,00 & $10.000,00$ & 0,00 & $10.000,00$ & 0,00 \\
\hline Teófilo Otoni/MG & 0,00 & 0,00 & $10.000,00$ & $10.000,00$ & $10.000,00$ & $10.000,00$ \\
\hline Goiânia/GO & $10.000,00$ & 0,00 & 0,00 & 0,00 & 0,00 & 0,00 \\
\hline Catalão/GO & 0,00 & 0,00 & 0,00 & $10.000,00$ & 0,00 & 0,00 \\
\hline Vitória da conquista/BA & $10.000,00$ & 0,00 & 0,00 & 0,00 & 0,00 & 0,00 \\
\hline Salvador/BA & $10.000,00$ & $10.000,00$ & $10.000,00$ & $10.000,00$ & $10.000,00$ & 0,00 \\
\hline Aracaju/SE & 0,00 & 0,00 & 0,00 & 0,00 & 0,00 & $10.000,00$ \\
\hline Maceió/AL & $20.000,00$ & $20.000,00$ & $10.000,00$ & $10.000,00$ & $10.000,00$ & 0,00 \\
\hline Ouricuri/PE & 0,00 & 0,00 & 0,00 & 0,00 & $10.000,00$ & 0,00 \\
\hline Sousa/PB & 0,00 & 0,00 & $10.000,00$ & $10.000,00$ & 0,00 & $10.000,00$ \\
\hline Juazeiro do Norte/CE & $10.000,00$ & $10.000,00$ & 0,00 & 0,00 & 0,00 & 0,00 \\
\hline \multirow{2}{*}{ Teresina/PI } & $10.000,00$ & $10.000,00$ & 0,00 & 0,00 & 0,00 & 0,00 \\
\hline & $170.000,00$ & $165.000,00$ & $150.000,00$ & $155.000,00$ & $155.000,00$ & $145.000,00$ \\
\hline Fabricas & T.B. total & T.B. total & T.B. total & T.B. total & T.B. total & T.B. total \\
\hline São Paulo/SP & $254.557,81$ & $258.122,61$ & $268.950,28$ & $264.692,16$ & $267.057,86$ & $271.022,60$ \\
\hline Joinville/SC & $109.661,63$ & $112.975,95$ & $115.806,50$ & $117.431,11$ & $118.673,36$ & $120.188,26$ \\
\hline Goiânia/GO & $48.083,35$ & $46.143,28$ & $47.890,85$ & $45.844,71$ & $41.822,24$ & $45.843,48$ \\
\hline \multirow[t]{2}{*}{ Recife/PE } & $11.614,49$ & $11.675,44$ & $11.269,64$ & $10.949,31$ & $11.363,83$ & $11.862,94$ \\
\hline & $423.917,28$ & $428.917,28$ & $443.917,27$ & $438.917,29$ & $438.917,29$ & $448.917,28$ \\
\hline
\end{tabular}

OBS: CD’s não listados não aparecem em nenhum dos cenários

Tabela 4.10. Tabela-resumo do cenário come preço médio de $\mathbf{R} \$ 625,00 /$ t. 
Igual ao padrão com $0 \%$ de sonegação (Solução Logística)

Muda da capacidade do $\mathrm{CD}$ em relação a Solução Logística

Muda da decisão de abrir ou fechar o CD em relação a Solução Logística

\begin{tabular}{|l|l|l|l|l|l|}
\hline \multicolumn{6}{|c|}{ Índice de Sonegacão } \\
\hline $0 \%$ & $20 \%$ & $40 \%$ & $60 \%$ & $80 \%$ & $100 \%$ \\
\hline
\end{tabular}

\begin{tabular}{|c|c|c|c|c|c|c|}
\hline CDs & T.B. total & T.B. total & T.B. total & T.B. total & T.B. total & T.B. total \\
\hline Porto Alegre/RS & $10.000,00$ & $10.000,00$ & $10.000,00$ & 0,00 & 0,00 & 0,00 \\
\hline Imbituba/SC & 0,00 & 0,00 & 0,00 & $10.000,00$ & $10.000,00$ & $10.000,00$ \\
\hline Joinville/SC & $10.000,00$ & $10.000,00$ & $10.000,00$ & 0,00 & 0,00 & 0,00 \\
\hline União da Vitória/PR & 0,00 & 0,00 & 0,00 & $10.000,00$ & $10.000,00$ & $10.000,00$ \\
\hline São Paulo/SP & $35.000,00$ & 0,00 & 0,00 & 0,00 & 0,00 & 0,00 \\
\hline Franca/SP & 0,00 & 0,00 & 0,00 & $20.000,00$ & $20.000,00$ & $20.000,00$ \\
\hline Rio de Janeiro/RJ & $35.000,00$ & $20.000,00$ & $20.000,00$ & $10.000,00$ & 0,00 & 0,00 \\
\hline Belo Horizonte/MG & $10.000,00$ & 0,00 & 0,00 & 0,00 & 0,00 & 0,00 \\
\hline Juiz de Fora/MG & 0,00 & 0,00 & 0,00 & $20.000,00$ & 0,00 & $20.000,00$ \\
\hline Pouso Alegre/MG & 0,00 & $75.000,00$ & $100.000,00$ & $100.000,00$ & $150.000,00$ & $150.000,00$ \\
\hline Uberlândia/MG & 0,00 & $10.000,00$ & $10.000,00$ & 0,00 & 0,00 & 0,00 \\
\hline Unaí/MG & 0,00 & 0,00 & 0,00 & $10.000,00$ & $10.000,00$ & $20.000,00$ \\
\hline Teófilo Otoni/MG & 0,00 & $10.000,00$ & $10.000,00$ & $10.000,00$ & $10.000,00$ & $10.000,00$ \\
\hline Goiânia/GO & $10.000,00$ & 0,00 & 0,00 & 0,00 & 0,00 & 0,00 \\
\hline Vitória da conquista/BA & $10.000,00$ & 0,00 & $10.000,00$ & 0,00 & 0,00 & 0,00 \\
\hline Salvador/BA & $10.000,00$ & $10.000,00$ & 0,00 & 0,00 & 0,00 & 0,00 \\
\hline Aracaju/SE & 0,00 & 0,00 & $20.000,00$ & $20.000,00$ & $10.000,00$ & $10.000,00$ \\
\hline Maceió/AL & $20.000,00$ & $20.000,00$ & 0,00 & 0,00 & 0,00 & 0,00 \\
\hline Ouricuri/PE & 0,00 & 0,00 & 0,00 & $10.000,00$ & 0,00 & 0,00 \\
\hline Sousa/PB & 0,00 & 0,00 & $10.000,00$ & 0,00 & $10.000,00$ & $8.484,89$ \\
\hline Juazeiro do Norte/CE & $10.000,00$ & $10.000,00$ & 0,00 & 0,00 & 0,00 & 0,00 \\
\hline Teresina/PI & $10.000,00$ & $10.000,00$ & 0,00 & 0,00 & 0,00 & 0,00 \\
\hline & $170.000,00$ & $185.000,00$ & $200.000,00$ & $220.000,00$ & $230.000,00$ & $258.484,89$ \\
\hline
\end{tabular}

\begin{tabular}{|l|r|r|r|r|r|r|}
\hline \multicolumn{1}{|c|}{ Fabricas } & \multicolumn{1}{c|}{ T.B. total } & \multicolumn{1}{c|}{ T.B. total } & T.B. total & T.B. total & T.B. total & \multicolumn{1}{c|}{ T.B. total } \\
\hline São Paulo/SP & $254.557,81$ & $238.050,43$ & $226.082,01$ & $208.534,56$ & $195.809,09$ & $177.226,24$ \\
\hline Joinville/SC & $109.661,63$ & $111.691,55$ & $113.778,54$ & $114.083,70$ & $115.809,84$ & $115.748,94$ \\
\hline Goiânia/GO & $48.083,35$ & $46.108,11$ & $43.567,15$ & $40.552,11$ & $40.371,46$ & $34.585,47$ \\
\hline Recife/PE & $11.614,49$ & $13.067,19$ & $10.489,59$ & $10.746,89$ & $11.926,88$ & $7.871,74$ \\
\hline & $423.917,28$ & $408.917,28$ & $393.917,29$ & $373.917,26$ & $363.917,27$ & $335.432,39$ \\
\hline
\end{tabular}

OBS: CD's não listados não aparecem em nenhum dos cenários

Tabela 4.11. Tabela-resumo do cenário com preço médio de $\mathbf{R} \$ \mathbf{1 . 2 5 0} / \mathrm{t}$. 


\begin{tabular}{|c|c|c|c|c|c|c|}
\hline & & \\
\hline & & & & & & \\
\hline & & \multirow{2}{*}{\multicolumn{5}{|c|}{$\begin{array}{l}\text { Igual ao padrão com } 0 \% \text { de sonegação (Solução Logística) } \\
\text { Muda da capacidade do CD em relação a Solução Logística } \\
\text { Muda da decisão de abrir ou fechar o CD em relação a Solução Logística }\end{array}$}} \\
\hline & & & & & & \\
\hline & \multicolumn{6}{|c|}{ Índice de Sonegacão } \\
\hline & $0 \%$ & $20 \%$ & $40 \%$ & $60 \%$ & $80 \%$ & $100 \%$ \\
\hline CDs & T.B. total & T.B. total & T.B. total & T.B. total & T.B. total & T.B. total \\
\hline Porto Alegre/RS & $10.000,00$ & $10.000,00$ & $10.000,00$ & 0,00 & 0,00 & 0,00 \\
\hline Imbituba/SC & 0,00 & 0,00 & 0,00 & $10.000,00$ & $10.000,00$ & $10.000,00$ \\
\hline Joinville/SC & $10.000,00$ & 0,00 & 0,00 & 0,00 & 0,00 & 0,00 \\
\hline União da Vitória/PR & 0,00 & $10.000,00$ & $10.000,00$ & $10.000,00$ & $10.000,00$ & $10.000,00$ \\
\hline São Paulo/SP & $35.000,00$ & 0,00 & 0,00 & $20.000,00$ & 0,00 & 0,00 \\
\hline Franca/SP & 0,00 & 0,00 & 0,00 & 0,00 & $20.000,00$ & $20.000,00$ \\
\hline Rio de Janeiro/RJ & $35.000,00$ & $20.000,00$ & $20.000,00$ & $10.000,00$ & 0,00 & 0,00 \\
\hline Belo Horizonte/MG & $10.000,00$ & $10.000,00$ & 0,00 & $10.000,00$ & 0,00 & 0,00 \\
\hline Juiz de Fora/MG & 0,00 & 0,00 & 0,00 & 0,00 & 0,00 & $20.000,00$ \\
\hline Pouso Alegre/MG & 0,00 & $75.000,00$ & $100.000,00$ & $100.000,00$ & $150.000,00$ & $150.000,00$ \\
\hline Uberlândia/MG & 0,00 & $10.000,00$ & 0,00 & $10.000,00$ & 0,00 & 0,00 \\
\hline Unaí/MG & 0,00 & 0,00 & $10.000,00$ & $10.000,00$ & $20.000,00$ & $20.000,00$ \\
\hline Teófilo Otoni/MG & 0,00 & $10.000,00$ & $10.000,00$ & $10.000,00$ & $10.000,00$ & $20.000,00$ \\
\hline Goiânia/GO & $10.000,00$ & 0,00 & 0,00 & 0,00 & 0,00 & 0,00 \\
\hline Catalão/GO & 0,00 & 0,00 & $10.000,00$ & 0,00 & 0,00 & 0,00 \\
\hline Vitória da conquista/BA & $10.000,00$ & 0,00 & 0,00 & 0,00 & 0,00 & 0,00 \\
\hline Salvador/BA & $10.000,00$ & $10.000,00$ & $10.000,00$ & $10.000,00$ & 0,00 & 0,00 \\
\hline Aracaju/SE & 0,00 & 0,00 & $20.000,00$ & $10.000,00$ & $10.000,00$ & $10.000,00$ \\
\hline Maceió/AL & $20.000,00$ & $20.000,00$ & 0,00 & 0,00 & 0,00 & 0,00 \\
\hline Ouricuri/PE & 0,00 & 0,00 & $10.000,00$ & 0,00 & 0,00 & 0,00 \\
\hline Sousa/PB & 0,00 & 0,00 & 0,00 & $10.000,00$ & $10.000,00$ & $7.849,81$ \\
\hline Juazeiro do Norte/CE & $10.000,00$ & $10.000,00$ & 0,00 & 0,00 & 0,00 & 0,00 \\
\hline Teresina/PI & $10.000,00$ & $10.000,00$ & 0,00 & 0,00 & 0,00 & 0,00 \\
\hline & $170.000,00$ & $195.000,00$ & $210.000,00$ & $220.000,00$ & $240.000,00$ & $267.849,81$ \\
\hline Fabricas & T.B. total & T.B. total & T.B. total & T.B. total & T.B. total & T.B. total \\
\hline São Paulo/SP & $254.557,81$ & $236.977,19$ & $222.585,30$ & $210.259,25$ & $196.024,70$ & $177.226,24$ \\
\hline \begin{tabular}{|l} 
Joinville/SC \\
\end{tabular} & $109.661,63$ & $110.852,56$ & $113.078,86$ & $114.313,52$ & $115.809,84$ & $111.727,68$ \\
\hline Goiânia/GO & $48.083,35$ & $42.359,17$ & $41.186,37$ & $39.159,98$ & $35.962,41$ & $32.724,86$ \\
\hline Recife/PE & $11.614,49$ & $8.728,35$ & $7.066,74$ & $10.184,52$ & $6.120,32$ & $4.388,69$ \\
\hline & $423.917,28$ & $398.917,27$ & $383.917,27$ & $373.917,27$ & $353.917,27$ & $326.067,47$ \\
\hline
\end{tabular}

OBS: CD's não listados não aparecem em nenhum dos cenários

Tabela 4.12. Tabela resumo do cenário com preço médio de $\mathbf{R} \$ \mathbf{5 . 0 0 0 , 0 0 / t}$.

Comparando-se as Tabelas 4.10 a 4.12, percebe-se que os cenários com preços médios de $\mathrm{R} \$ 1.250$ e $\mathrm{R} \$ 5.000$ tem comportamento semelhante, com volumes via CD crescentes com o índice de sonegação e uma lista de locais escolhidos quase coincidente (com exceção de Catalão/GO). Entretanto, o cenário com preço médio de $\mathrm{R} \$ 625$ tem volumes decrescentes com o aumento da sonegação.

Os diversos gráficos de barras de custos vão auxiliar a esclarecer esta questão (vide Figuras 4.23 a 4.25$)$. 


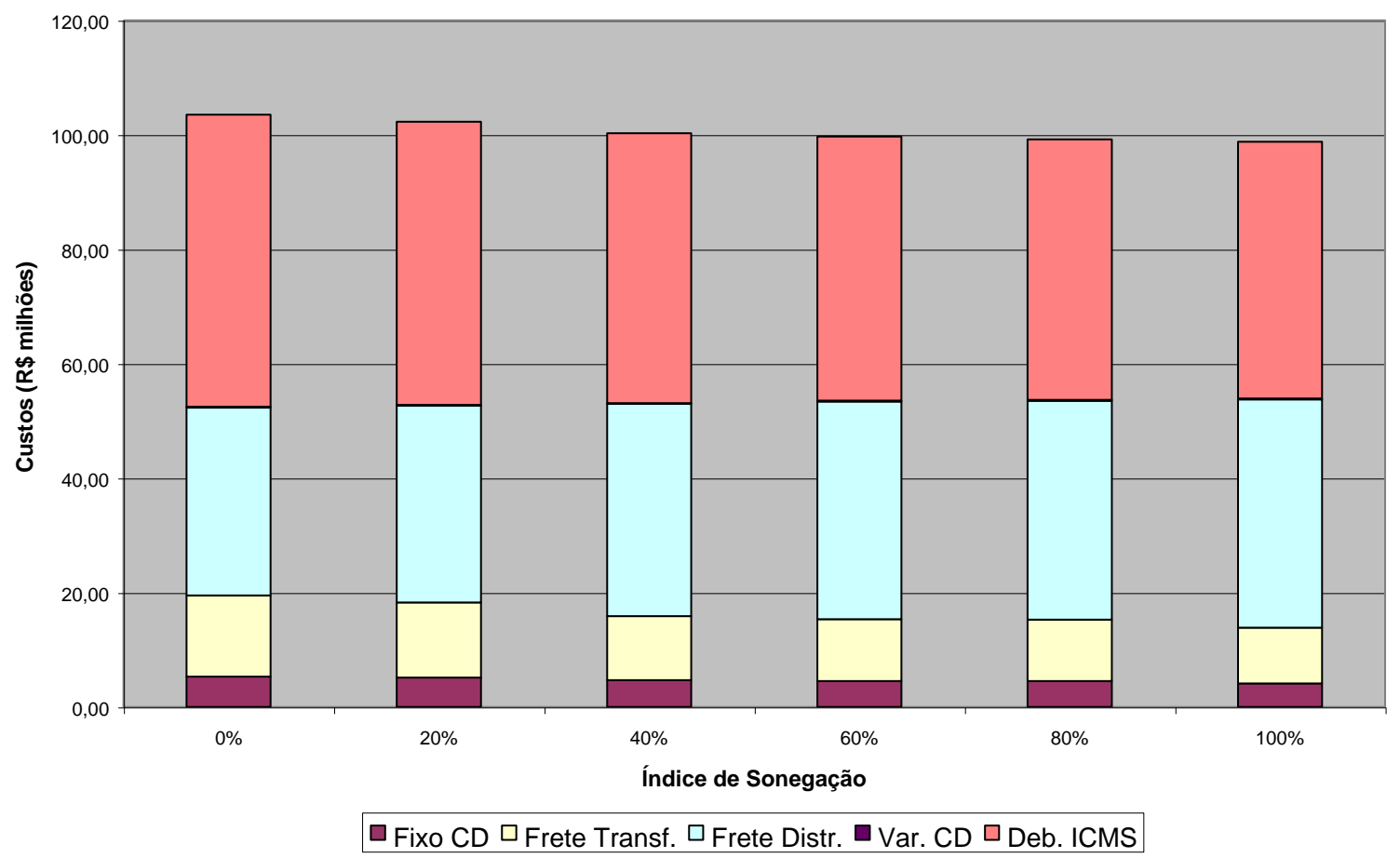

Figura 4.23. Custos componentes para cenário com preço de $R \$ 625,00 / t$

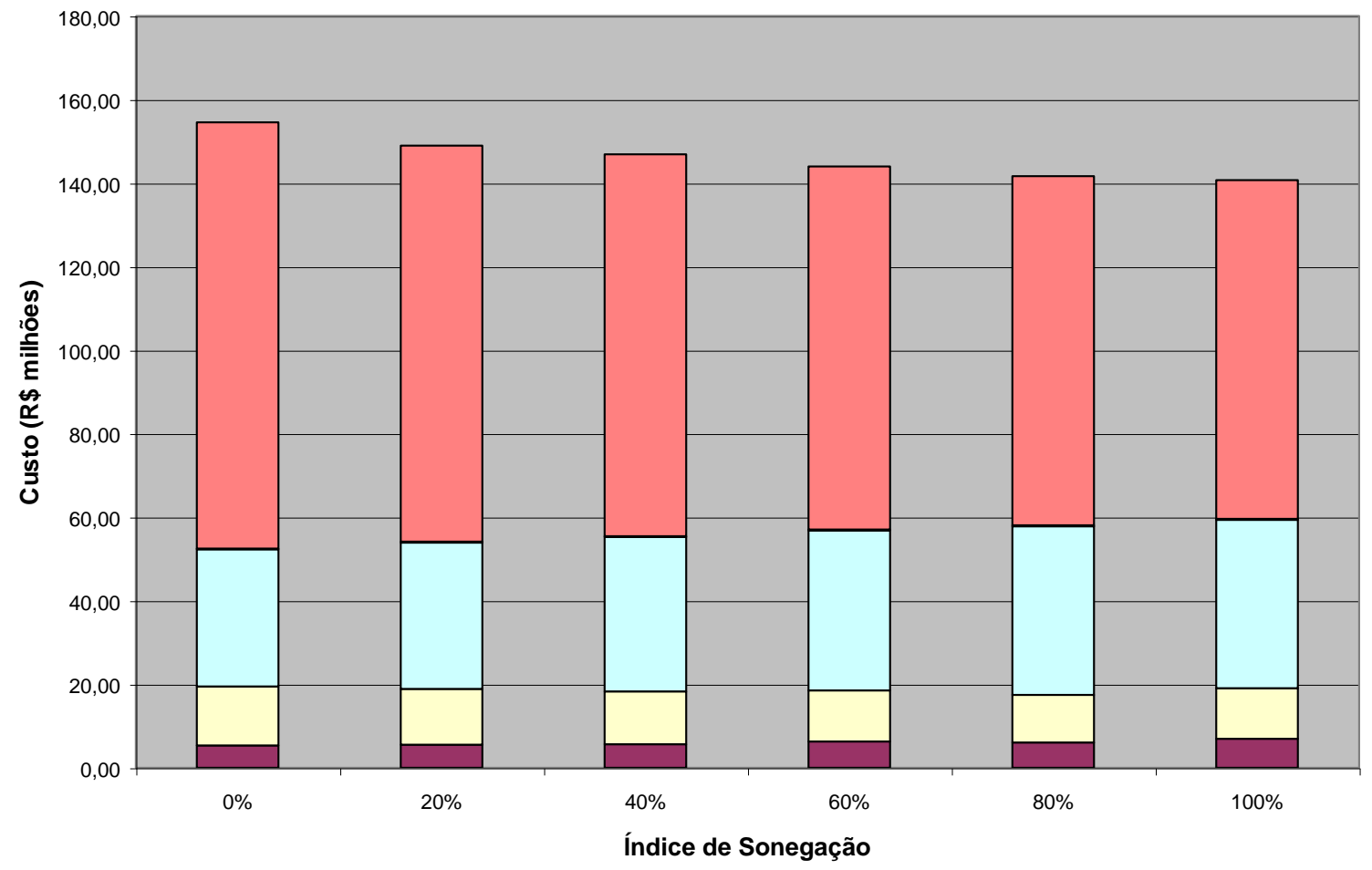

$\square$ Fixo CD $\square$ Frete Transf. $\square$ Frete Distr. $\square$ Var. CD $\square$ Deb. ICMS

Figura 4.24. Custos componentes para cenário com preço de $\mathbf{R} \$ 1.250,00 / t$ 


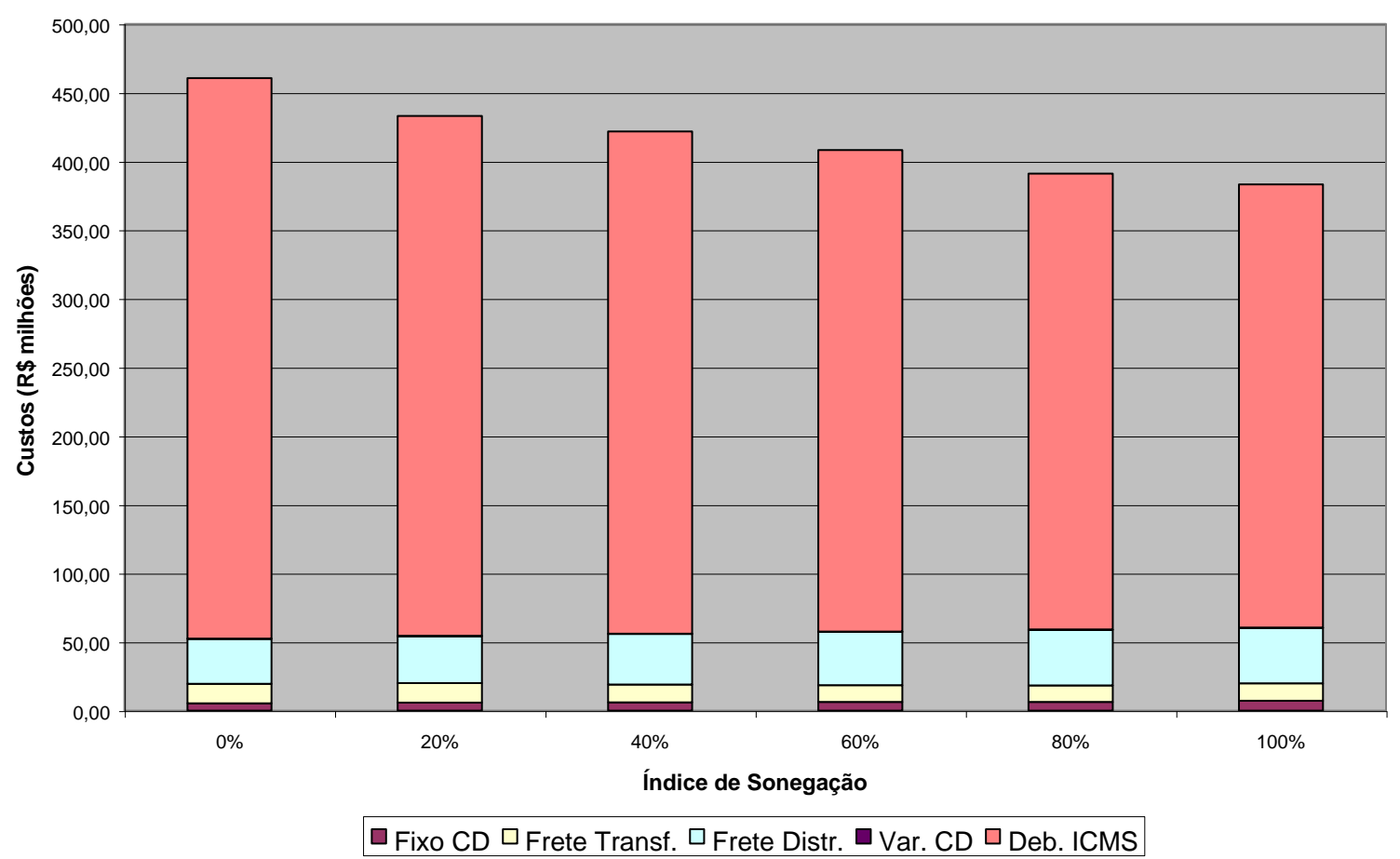

Figura 4.25. Custos componentes para cenário com preço de $\mathbf{R} \$ \mathbf{5 . 0 0 0 , 0 0 / t}$.

Olhando-se os gráficos acima, pode-se verificar que nos cenários com preços médios maiores, o débito do ICMS prepondera sobre o custo logístico. No preço médio de $\mathrm{R} \$ 625$, porém, ambos têm a mesma ordem de grandeza. De fato, a curva de tradeoffs (vide Figura 4.26) entre custos logísticos e ICMS denuncia isto: pela primeira vez, o valor absoluto do débito total do ICMS fica abaixo dos custos logísticos. 


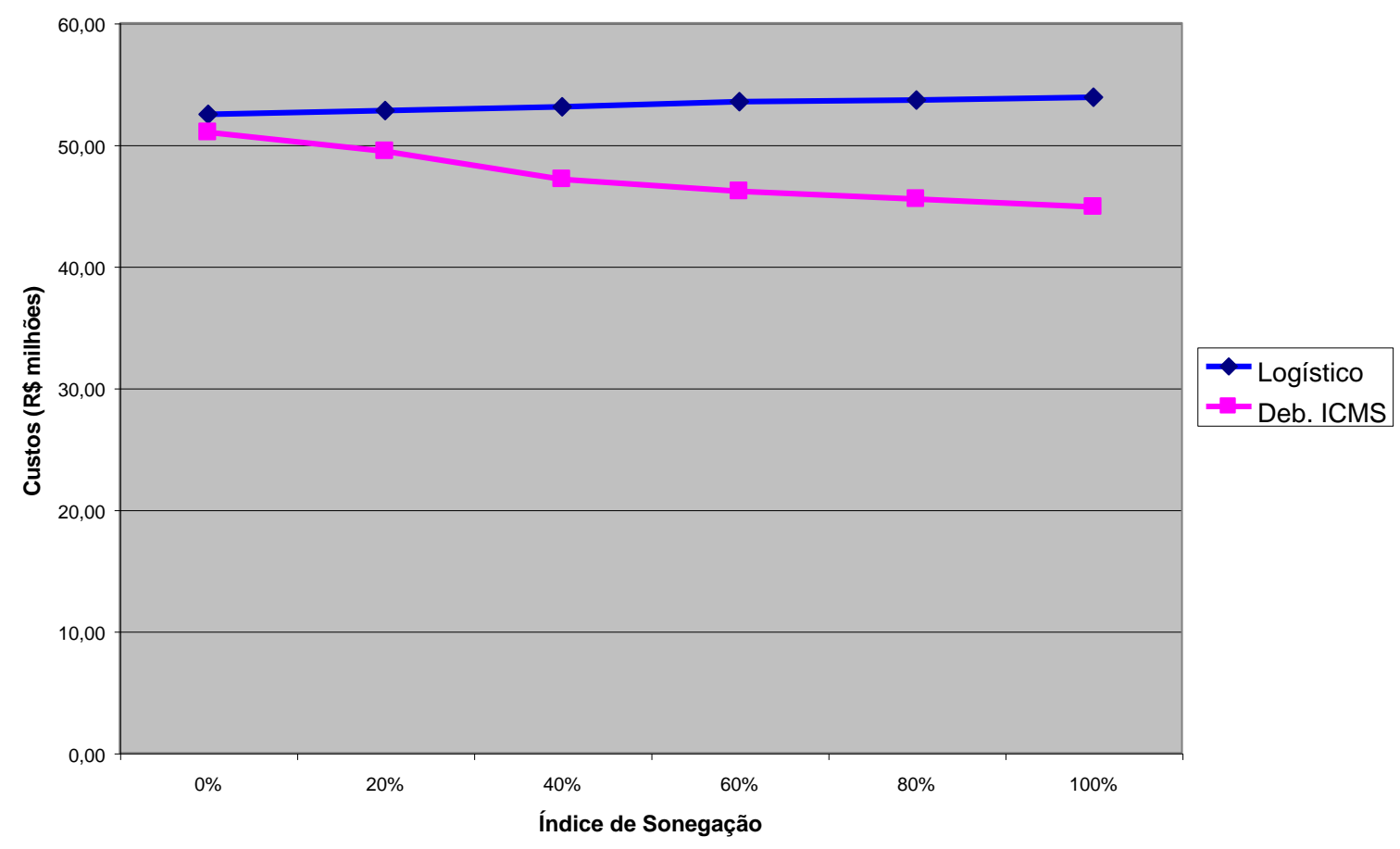

Figura 4.26. Curva de tradeoff entre custo logístico e ICMS, preço médio R \$625/t.

Desta forma, deve haver algum tipo de inflexão ou mudança de curvatura no comportamento dos custos totais, pois em valores próximos do preço médio zero a influência do ICMS também seria nula. Isto deve se refletir na curva de custos logísticos.

Assim, preparou-se uma superfície de custos logísticos em função do preço médio e do índice de sonegação, mostrada na Figura 4.27. Pode-se ver que a mesma tem um crescimento acentuado após o preço médio de $\mathrm{R} \$ 625$ e vai se estabilizando após $\mathrm{R} \$$ 2.500,00. Este comportamento era esperado, pois a influência do ICMS vai se esvaindo quando o preço médio diminui (preço zero equivale, em termos da modelagem, a sonegação zero). Por outro lado, a partir de certo ponto, não há mais "turismo" potencial a ser ganho, mesmo que o preço aumente. Assim, a superfície do custo logístico adquire essa aparência planar ou de telhado de uma água a partir do valor de $\mathrm{R} \$ 1.250$. 


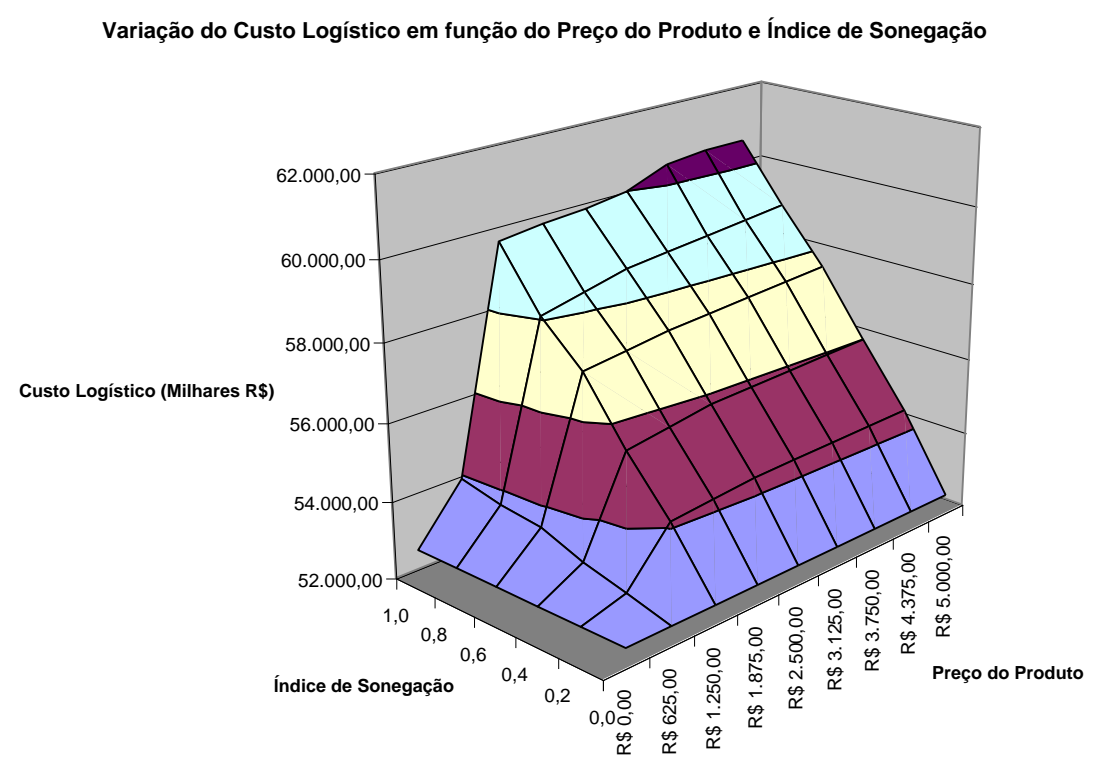

$\square 52.000,00-54.000,00 \square 54.000,00-56.000,00 \square 56.000,00-58.000,00 \square 58.000,00-60.000,00 \square 60.000,00-62.000,00$

Figura 4.27. Superfície de custo logístico em função de sonegação e preço.

\subsection{Conclusões}

Verificou-se que efetivamente existe um tradeoff entre os custos logísticos (fixos e variáveis de armazenagem, fretes de transferência e de distribuição). Ele influencia de maneira muito forte o projeto da rede de instalações; para valores usuais das mercadorias de supermercado ( $\mathrm{R} \$ 2.500,00)$, sendo bastante sensível ao nível de sonegação no canal de vendas. Pequenos índices de sonegação (20\%) são suficientes para mudar radicalmente a configuração da rede logística. Há também um ganho de escala na distribuição compartilhada.

Assim, podem ser considerados atingidos os objetivos definidos na Introdução da tese, ou seja, determinar e estudar os tradeoffs entre custos logísticos e a estrutura de alíquotas do ICMS, avaliar a influência deste tributo no projeto de localização de centros de distribuição e discutir seu impacto na logística e no projeto de redes de distribuição física. 
No capítulo seguinte vai-se explorar o significado dessas descobertas e discutir implicações das mesmas, tanto em termos das empresas que operam nesse ambiente como do ponto de vista geral. Conclusões gerais são também tecidas, além de propostas para trabalhos vindouros. 


\section{CONCLUSÕES FINAIS E FECHAMENTO}

Arthur Geoffrion, ex-presidente do Institute for Operations Research and the Management Sciences, uma vez comentou que modelos devem ser usados para adquirir conhecimento e não somente para obter respostas a problemas (Geoffrion, 1976b). Ele também enfatizou a necessidade de se apreciar os tradeoffs que existem em qualquer situação que se deseje modelar matematicamente ${ }^{9}$. Assim, os resultados vistos no capítulo anterior servem igualmente para a reflexão e a crítica da situação modelada e não meramente como uma resposta quantitativa: apesar da grande dose de processamento computacional empregada, as conclusões também são qualitativas.

Este capítulo finaliza a tese e começa pela discussão de conclusões aplicadas à realidade econômica brasileira (o "custo Brasil" da estrutura de alíquotas do tributo) e os seus desdobramentos na prática da Logística Empresarial no país. Em seguida, críticas e comentários sobre o trabalho são apresentados. Finalmente, fecha-se a tese com propostas de futuros estudos.

\subsection{Conclusões sobre a estrutura de alíquotas do ICMS e a Logística}

\subsection{1. "Custo Brasil" da atual estrutura do ICMS}

Foi possível quantificar parametricamente o impacto da estrutura de alíquotas interestaduais do ICMS nos custos logísticos com a estrutura física (instalações) de distribuição otimizada. Olhando-se os diversos cenários, os seguintes incrementos nos custos logísticos considerados (fixos das instalações, transbordos e fretes) se apresentam, calculados como aumento percentual sobre o custo do cenário $0 \%$ de sonegação:

\footnotetext{
${ }^{9}$ Comunicação pessoal, julho de 1996.
} 


\begin{tabular}{|l|c|c|c|c|c|c|}
\hline Índice de sonegação & $\mathbf{0 \%}$ & $\mathbf{2 0 \%}$ & $\mathbf{4 0 \%}$ & $\mathbf{6 0 \%}$ & $\mathbf{8 0 \%}$ & $\mathbf{1 0 0 \%}$ \\
\hline Incremento & $0 \%$ & $3,49 \%$ & $6,33 \%$ & $9,24 \%$ & $11,63 \%$ & $14,00 \%$ \\
\hline
\end{tabular}

Tabela 5.1. Aumento relativo no custo logístico (cenário base preço $\mathbf{R} \$ \mathbf{2 . 5 0 0 / t}$ )

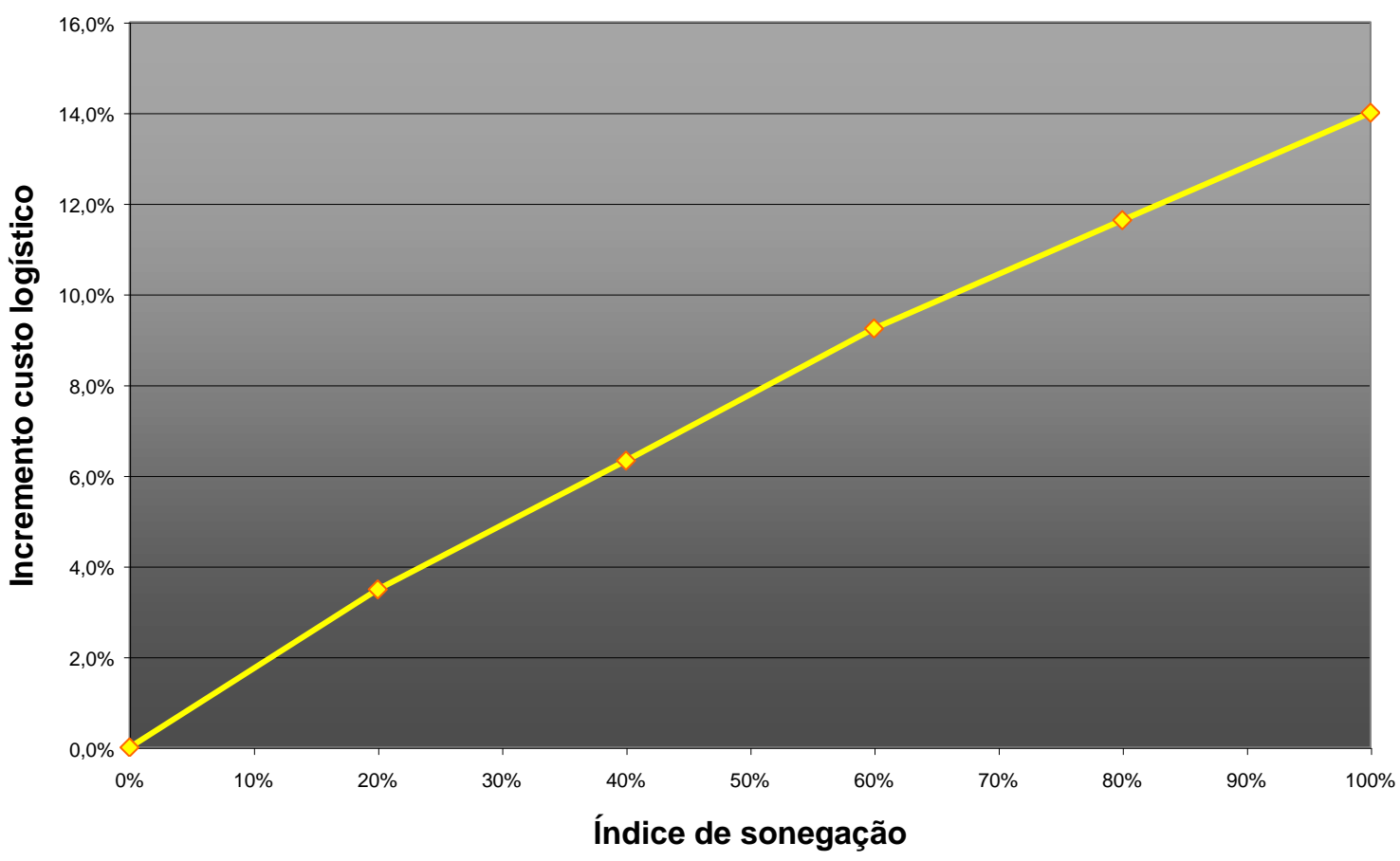

Figura 5.1. Aumento relativo do custo logístico, cenário com preço $\mathbf{R} \$ 2.500 / t$

Olhando-se tanto a Tabela 5.1 como a figura acima, pode-se verificar que há um significativo acréscimo nos custos logísticos. Por exemplo, caso as indústrias adotem uma hipótese conservadora de $20 \%$ de sonegação na cadeia, a rede logística desenhada gera um incremento de 3,49\% nos custos de operação do cenário básico (considerando-se somente fatores logísticos). Considerando-se que em torno de $15 \%$ da distribuição é feita via grandes redes (Tabela 2.1, Capítulo 2) - que são consideradas como não sonegadores devido ao alto risco envolvido - pode-se adotar como limite superior para o índice de sonegação a fração de $80 \%$ e, nesse caso, o aumento do custo logístico fica em 11,63\%.

Assim, o "turismo" causado pela atual estrutura do ICMS pode redundar em significativo ônus para as operações logísticas. 
A análise de sensibilidade realizada anteriormente permite avaliar o impacto dos preços médios na ampliação do custo logístico ocasionada pela estrutura do ICMS, sempre sob a perspectiva de otimizar os resultados globais para as indústrias com a distribuição conjunta. Calculando-se o incremento relativo ao se variar o preço, obtém-se a Tabela 5.2.

\begin{tabular}{|c|c|c|c|c|c|c|}
\hline & \multicolumn{7}{|c|}{ Índice de sonegação } \\
\hline Preço médio & $\mathbf{0 \%}$ & $\mathbf{2 0 \%}$ & $\mathbf{4 0 \%}$ & $\mathbf{6 0 \%}$ & $\mathbf{8 0 \%}$ & $\mathbf{1 0 0 \%}$ \\
\hline R\$ 625/t & $0 \%$ & $0,61 \%$ & $1,17 \%$ & $1,97 \%$ & $2,23 \%$ & $2,70 \%$ \\
\hline R\$ 1.250/t & $0 \%$ & $3,10 \%$ & $5,67 \%$ & $8,69 \%$ & $10,64 \%$ & $13,58 \%$ \\
\hline R\$ 2.500/t & $0 \%$ & $3,49 \%$ & $6,33 \%$ & $9,24 \%$ & $11,63 \%$ & $14,00 \%$ \\
\hline R\$ 5.000/t & $0 \%$ & $3,69 \%$ & $6,68 \%$ & $9,85 \%$ & $12,47 \%$ & $15,30 \%$ \\
\hline
\end{tabular}

Tabela 5.2. Incremento relativo do custo logístico com relação ao cenário 0\% de sonegação

A tabela mostra que, para preços médios superiores a $\mathrm{R} \$ 1.250 / \mathrm{t}$, o comportamento do aumento de custo logístico para redução do débito do ICMS é semelhante. Porém, como visto no capítulo anterior, se o preço médio for $\mathrm{R} \$ 625$, o comportamento fica bem diferente, com aumentos menos expressivos.

Pode-se mostrar os valores tabulados de forma gráfica, como na Figura 5.2. 


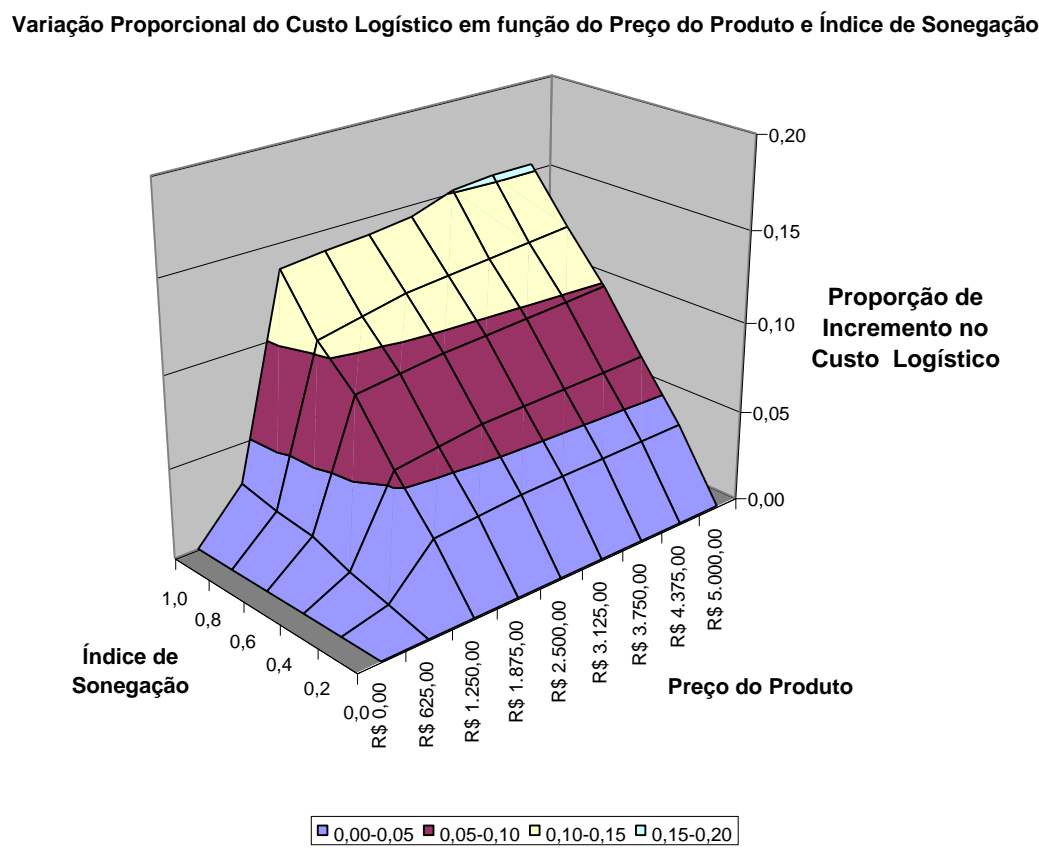

Figura 5.2. Crescimento relativo do custo logístico em função do preço e da sonegação

Além do desperdício econômico que o "turismo" de mercadorias acarreta, há igualmente perdas não computadas aqui, como o aumento do tráfego de caminhões pesados em certas estradas, possibilitando congestionamentos, acidentes, etc, além do maior desgaste do pavimento das rodovias, diminuindo sua vida útil. É uma movimentação gerada de forma artificial e que não agrega valor econômico ao produto, qualificando mais um "custo Brasil”.

No final do item 2.7, Capítulo 2, discutiu-se algumas maneiras de resolver o problema do "turismo" através de expedientes como a substituição tributária, ação nos postos de fronteira, o Imposto sobre Valor Agregado e o recolhimento no início da cadeia de distribuição (indústria). Todas estas propostas esbarram em dificuldades práticas. Uma maneira não discutida seria a eliminação da causa básica, que são as diferentes alíquotas para transações interestaduais expostas na Tabela do CONFAZ (Anexo B). Assim, seria possível definir uma alíquota única, que seria aplicada em operações internas e interestaduais. Entretanto, isto esbarra na questão do rateio do recolhimento do imposto entre os Estados, pois as regiões mais industrializadas se 
beneficiariam mais que as menos industrializadas (aliás, esta é a causa das alíquotas interestaduais diferentes).

\subsubsection{A vantagem de ter distribuição nacional}

Uma questão interessante que surge é a vantagem de empresas com alcance nacional (como as grandes marcas) sobre as empresas puramente locais. Isto ocorre porque elas pagam um menor débito relativo de ICMS, enquanto as firmas locais (que atendem mercados também limitados) pagam a alíquota interna de seus Estados.

É fácil calcular a "alíquota média" em cada cenário, pois a movimentação total, o preço médio e o débito otimizado foram calculados na cadeia de distribuição. Esse débito médio assim representaria o que ocorre com empresas do cenário base, todas com vendas nacionais. Logo, obtém-se a Tabela 5.3 a seguir.

\begin{tabular}{|c|c|c|c|c|c|c|}
\hline & \multicolumn{7}{|c|}{ Índice de sonegação } \\
\hline Preço médio & $\mathbf{0 \%}$ & $\mathbf{2 0 \%}$ & $\mathbf{4 0 \%}$ & $\mathbf{6 0 \%}$ & $\mathbf{8 0 \%}$ & $\mathbf{1 0 0 \%}$ \\
\hline R\$ 625/t & $13,75 \%$ & $13,33 \%$ & $12,70 \%$ & $12,43 \%$ & $12,26 \%$ & $12,09 \%$ \\
\hline R\$ 1.250/t & $13,75 \%$ & $12,77 \%$ & $12,31 \%$ & $11,71 \%$ & $11,26 \%$ & $10,92 \%$ \\
\hline R\$ 2.500/t & $13,75 \%$ & $12,75 \%$ & $12,32 \%$ & $11,82 \%$ & $11,20 \%$ & $10,90 \%$ \\
\hline R\$ 5.000/t & $13,75 \%$ & $12,75 \%$ & $12,31 \%$ & $11,80 \%$ & $11,18 \%$ & $10,87 \%$ \\
\hline
\end{tabular}

Tabela 5.3. Recolhimento médio de ICMS por cenário (débito/faturamento, em \%) 


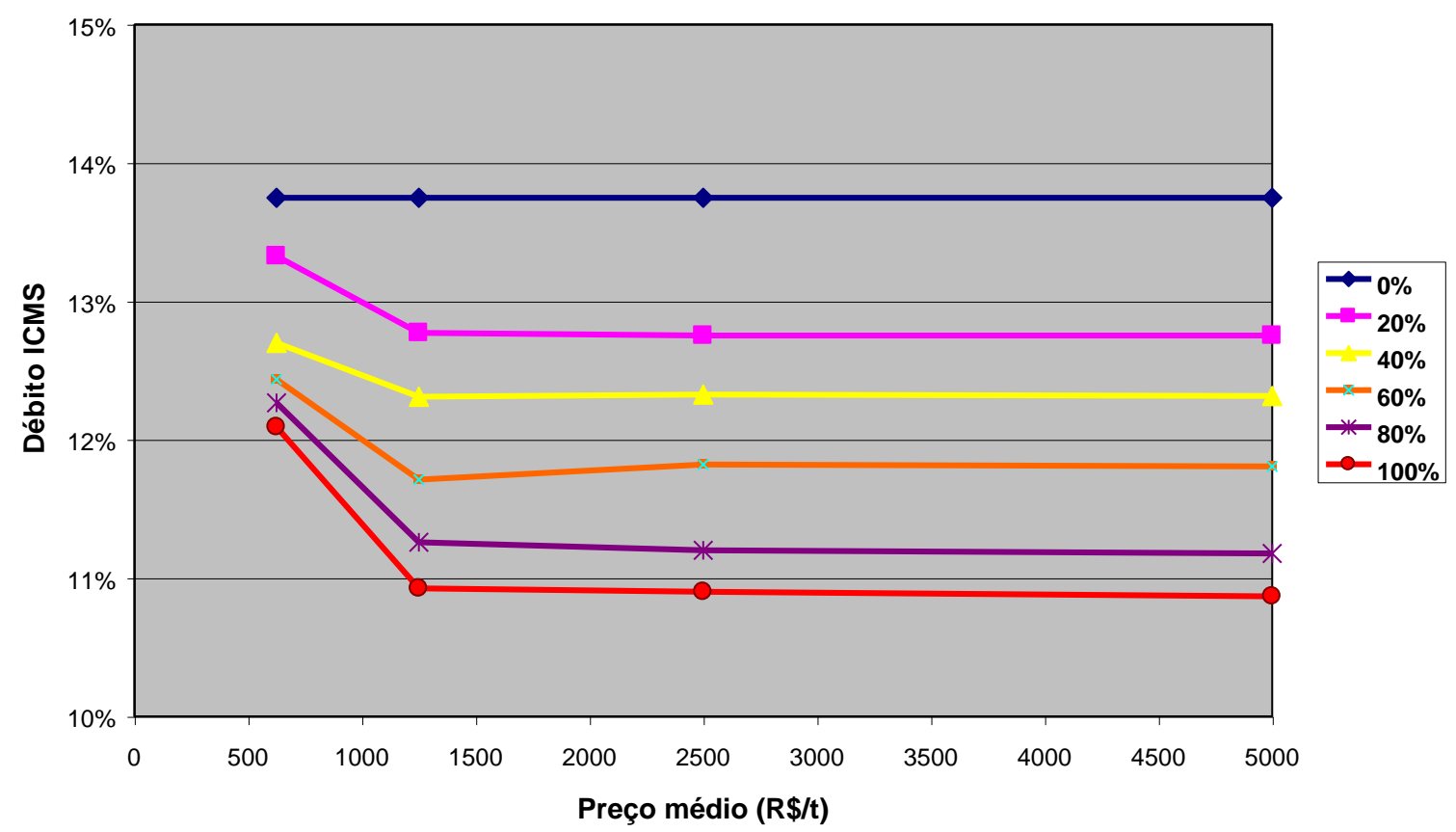

Figura 5.3. Variação do débito relativo do ICMS (\% preço médio) conforme preço médio e índice de sonegação, para o agregado das indústrias (distribuição conjunta)

Plotou-se os valores da tabela em um gráfico parametrizado pelo índice de sonegação para se conseguir a Figura 5.3.

Assumindo-se que este seria o recolhimento proporcional médio das indústrias nos cenários otimizados, tem-se aqui um resultado interessante: o débito relativo médio fica entre um teto de $13,75 \%$ e um mínimo de $10,87 \%$. É interessante que a variação do débito médio virtualmente se estabiliza após o preço médio de $\mathrm{R} \$ 1.250 / \mathrm{t}$ para qualquer índice assumido de sonegação na cadeia. Caso essas indústrias que fazem a distribuição compartilhada optem por uma rede otimizadas apenas do ponto de vista logístico (índice zero), o débito relativo médio é constante e igual a 13,75\%.

É importante comentar que não se sabe o real nível de otimização da distribuição física no Brasil, tanto em termos de operação logística pura (ou seja, assumir sonegação zero na cadeia) ou de planejamento tributário puro (ou seja, olhando-se apenas os ganhos possíveis no débito de impostos e outras taxas). 
Um exemplo é o das empresas que privilegiam somente o nível de serviço. Grandes indústrias de produtos supermercadistas costumam olhar seu mercado sob o prisma de seus principais clientes (chamados por eles de key accounts) e, assim, não consideram a questão do ICMS no desenho de suas redes logísticas. Em uma delas, quase $40 \%$ de suas vendas ocorre por esse canal. Assim, o recolhimento realizado deve estar próximo do cenário sem sonegação assumida (débito relativos de 13,75\%).

Assim, mesmo nesse caso de débito médio maior, as indústrias de alcance nacional têm vantagem sobre indústrias locais, que vão recolher alíquotas de $17 \%$ ou $18 \%$.

Naturalmente, está-se avaliando cenários idealizados, pois empresas de vendagem nacional nem sempre consideram o efeito tributário, com alguns episódios curiosos. $\mathrm{O}$ autor desta tese uma vez entrevistou o pessoal de uma indústria líder de alimentos, com fábricas em diversos Estados do Sudeste, menos no Rio de Janeiro. Todos os clientes do Rio poderiam ser satisfatoriamente atendidos a partir das fábricas paulistas e mineiras, com evidentes vantagens fiscais. Entretanto, o atendimento dos clientes cariocas era feito a partir de um armazém próprio situado na Grande Rio. Inquiridos sobre a razão de não se utilizar a vantagem tributária de usar os estabelecimentos de São Paulo e Minas, a resposta foi surpreendente: se o faturamento (emissão da nota fiscal) fosse realizado pelo CD de São Paulo ou de Minas, ele seria lançado como vendas realizadas por aquelas Regionais de vendas e isto prejudicaria a equipe carioca, pois o dado de entrada do sistema de cálculo de comissões de venda era o local de faturamento. A vida sempre consegue ser mais criativa do que a arte.

\subsubsection{Incorporar ICMS e outros impostos na Logística Empresarial}

As histórias da página anterior mostram que algumas empresas ignoram ou desconsideram a questão fiscal ao fazer seu projeto da rede física de distribuição. Esta tese mostra os perigos (e custos) de se ignorar o planejamento tributário e se concentrar somente em aspectos comerciais e de operação. 
Evidentemente, as empresas precisam conhecer sua cadeia de distribuição e a segmentação de seus clientes e dos clientes de seus clientes (a visão sistêmica da cadeia), de forma que possa determinar a real possibilidade de utilizar a estrutura do ICMS para sua vantagem. Condições de competição local também afetam a decisão de quando e como utilizar esse expediente.

Os valores envolvidos são significativos e, para valores habituais no mercado de bens de consumo não duráveis, a questão fiscal sempre sobrepuja a operação. A extrema sensibilidade da localização dos depósitos para pequenas alterações no nível de sonegação (ver Capítulo 4) mostra isso de forma eloqüente. Esta é uma lição importante para os profissionais de logística, que às vezes possuem um viés técnico muito grande. O conhecimento da estrutura dos tributos é tão importante para eles quanto o conhecimento de técnicas de otimização ou de engenharia industrial.

Uma outra questão diz respeito ao "turismo" de mercadorias. Como foi dito anteriormente, a melhor maneira de identificar este fato é através da inspeção visual dos mapas, procurando-se as áreas de influência de fábricas e armazéns. Quando produtos manufaturados em Recife vão para um depósito aberto em Maceió e depois voltam para Pernambuco, fica simples qualificar o "turismo". Ou quando se instala um CD em Pouso Alegre para escoar produtos paulistas de volta para São Paulo. Porém, nem sempre as ineficiências são tão claras e transparentes. Algumas vezes ocorreu o inverso: centros de distribuição foram fechados e se partiu para uma entrega direta, penalizando o nível de serviço para localidades sem grande volume de demanda. O caso emblemático foi descrito no capítulo 4, ao se comentar o fechamento do CD de Brasília para escoar os produtos vindos de Joinville diretamente da fábrica (item 4.1). Assim, a estrutura do ICMS leva tanto à instalação de CD's para o "turismo" como ao fechamento de CD's "logísticos" para fazer entrega direta da fábrica. Logo, é falacioso dizer que o ICMS gera maior "turismo": às vezes ele pode reduzir o fluxo de mercadorias via depósitos intermediários ${ }^{10}$.

\footnotetext{
${ }^{10}$ A venda FOB de biscoitos para distribuidores do Norte/Nordeste, que vêm buscar a mercadoria na fábrica paulista (Capítulo 1, item 1.2.2), é um exemplo real desse fato.
} 
Uma fácil identificação de ineficiências geradas pela atual estrutura de alíquotas interestaduais do ICMS é assim uma quimera, pois sua influência se dá através de mais de um tipo de formato. Evidentemente, as exigências de nível de serviço e as restrições de capacidade agregam outros tradeoffs, gerando uma teia de inter-relações complexas que tornam qualquer regra de análise trivial pouco eficaz. Assim, para uma companhia empreender ao projeto da sua rede logística considerando o impacto da estrutura de tributos, ela deve utilizar métodos suficientemente elaborados, que abranjam a riqueza e complexidade dos tradeoffs envolvidos.

\subsection{Críticas e comentários sobre a modelagem empregada}

Algumas hipóteses e considerações deste trabalho são aqui revistas e criticadas: a questão da economia de escala com a distribuição compartilhada em um operador logístico; a modelagem de custos de armazenagem por uma poligonal, considerando custos fixos e variáveis; a não-consideração dos custos de manutenção de estoques; e, finalmente, a demanda utilizada e o volume total movimentado dentro do sistema.

Economia de escala pela distribuição conjunta em um operador logístico. Como visto no início do Capítulo 4 (item 4.2), é inegável a existência de economia de escala ao se consolidar as entregas de quatro indústrias. Avaliando o ganho obtido no cenário sem sonegação (pois vai ser comentado apenas o ponto de vista de operações), verifica-se uma redução de apenas 3,4\% no custo logístico. Os ganhos principais ocorrem pelo fechamento de CD's e pela consolidação dessas cargas. Entretanto, ao se avaliar com mais detalhes a solução proposta pelo modelo, vê-se uma coisa interessante: no caso consolidado, há a abertura de CD’s nos centros que já tem essas indústrias instaladas (vide Tabelas 4.3 e 4.9), como São Paulo e Goiânia. Naturalmente, nível de serviço permitindo, a fábrica de São Paulo não abriria um CD na cidade pois já conta com o depósito da fábrica nesse Estado. Porém, as outras fábricas que estão a mais de $500 \mathrm{~km}$ de distância precisam de uma instalação próxima à Grande São Paulo e, por isso, é aberto um armazém para atendê-los. A mesma coisa acontece nos CD’s de Joinville e Goiânia; o CD que atende a 
mesorregião de Recife fica em Maceió/AL. Assim, todos tem que compartilhar custos da abertura de CD’s em locais evidentemente não-ótimos do ponto de vista individual. A forma de rateio dos custos fixos dos CD’s, que vai condicionar a remuneração do operador logístico, vai ser então um fator primordial para garantir que as economias sejam efetivas para todas as indústrias participantes. Há evidentemente, um menor custo logístico por tonelada, se calculado de forma global. O problema é como repartir este butim e será tema de trabalhos futuros.

Custos de armazenagem e manuseio no centro de distribuição. Para modelar a estrutura de custos fixos e variáveis de um centro de distribuição e as economias de escala envolvidas (vide item 3.4, capitulo 3), foi utilizado um conjunto de segmentos de reta, onde para cada capacidade de um depósito está associado um determinado custo fixo (Tabela 3.4), obtido com a Equação 3.11. Pode-se perceber, ao analisar os resultados do modelo, que a capacidade dos CD's é normalmente uma restrição ativa: assim, existem fluxos que seriam designados para um depósito mas não o são pois a economia gerada no transporte não justifica o custo fixo de se ir para outro patamar de capacidade. Na realidade, porém, a capacidade de CD’s é uma variável contínua. Desta forma, um tratamento não linear poderia ser aplicado e será tema de novas pesquisas.

Custo de manutenção de estoques. Não se considerou o custo de manutenção de estoques na modelagem do problema. Essa hipótese é relativamente forte, pois descobriu-se que o volume total movimentado pelos centros de distribuição aumenta com o nível de sonegação. Assim, há um tradeoff entre custos de estoque e o débito de ICMS a ser considerado. Esse valor adicional de estoques é tão mais significativo quanto maior o valor médio da mercadoria. Outrossim, há um efeito não linear associado ao número de depósitos na rede de distribuição, ocasionado pelo incremento no estoque de segurança (Ballou, 1984). Assim, a aparência da superfície de custos logísticos (vide Figura 4.27) para preços médios maiores se modificaria, afetando as soluções obtidas. 
Custos de manutenção de estoques podem então ser significativos para este estudo de localização. Admitindo taxa de oportunidade de $12 \%$ a.a. e um giro de estoques de 12 vezes a.a., o aumento no custo de manutenção de estoques nos CD's pode ser estimado. No cenário base (preço médio de $\mathrm{R} \$ 2.500 / \mathrm{t}$ ), o volume movimentado via CD’s, no caso do índice de sonegação de $100 \%$, é de 258.500 t/ano (Tabela 4.6). Comparando-se com o cenário com índice de sonegação nulo, onde o volume anual pelos CD’s foi de $170.000 \mathrm{t}$, o incremento seria de (258.500-170.000 = 88.500 t/ano), que daria um incremento no custo de estoques de $\mathrm{R} \$ 2,2$ milhões por ano, que é da ordem de grandeza da variação dos custos fixos de CD’s e dos fretes de distribuição.

Demanda total e volume usados no estudo. A movimentação total em cada cenário era a soma das demandas dos produtos, que é 593.917,28 t/ano. Apesar de ser um número respeitável, não é uma quantidade irrealista, como discutido no item 3.4, Capítulo 3. Por essa razão, não foi cogitado realizar uma análise de sensibilidade com os fluxos movimentados para verificar o efeito da escala nas conclusões do modelo.

Entretanto, isto pode ser desenvolvido em projetos posteriores. As maiores empresas de alimentos e higiene/limpeza do país movimentam mais de um milhão de toneladas brutas por ano cada uma. Fluxos logísticos desta monta são assim uma possibilidade real e o aumento da escala de operação pode ser uma análise vindoura.

\subsection{Propostas de estudos futuros}

Existe uma fina ironia na confecção de teses: ao chegar ao seu término, elas costumam deixar novas questões em aberto, às vezes em número maior do que respostas que elas oferecem. Em teses de livre docência, além de uma ironia, é uma virtude, pois facilita a seleção de boas opções para a continuidade do trabalho.

A exploração dos resultados obtidos deve abrir novas linhas para pesquisa, em diversos níveis: pós-doutorado, doutorado, mestrado, iniciação científica. Os temas 
propostos para continuidade são apresentados abaixo e foram divididos em dois grupos: extensões diretas desta tese e problemas de modelagem para projeto de redes logísticas.

\subsubsection{Extensões diretas da tese}

Como foi visto no item 5.2, há diversas possibilidades para estender o assunto Logística e ICMS/estrutura tributária. Duas opções em particular são atraentes:

- Desenvolver novas análises de sensibilidade.

- Avaliar como as indústrias realmente tratam a questão.

Desenvolver novas análises de sensibilidade. Há diversos parâmetros que poderiam ser alterados para aprofundar o entendimento da inter-relação Logística x ICMS: a demanda total (alteração de escala de operações); melhorar a definição da superfície de custos logísticos na zona de transição entre influência logística (mais próximo de preço médio zero) e do ICMS (preços médios maiores que $\mathrm{R} \$ 625$ ); alterar o nível de serviço (isto teria grande impacto nos resultados e nos tempos de processamento); rever os valores de fretes para o ano 2002 (o ano base do estudo foi 2000); alterar a localização e o número de fábricas/origens (influência da topologia).

Avaliar como as indústrias trabalham. Podem ser feitas pesquisas de campo para entender como as indústrias realmente se comportam com relação aos tributos, através de questionários, entrevistas formais e levantamentos em dados secundários. Seria conveniente verificar também como a cadeia de distribuição (atacadistas, varejistas) se comporta, assim como outros atores (operadores logísticos, transportadoras, etc).

\subsubsection{Modelagem matemática para o projeto de redes logísticas}

O autor vem militando há alguns anos no tema, seja como pesquisador (Yoshizaki; Muscat; Biazzi, 1996; 1997: Kawamura; Ronconi; Yoshizaki, 2002) ou orientador de 
Trabalhos de Formatura (Gianella, 1989; Amaral, 1991; Zennaro, 1993; Nascimento, 2001) e Dissertações de Mestrado (Martos, 2000), sempre aplicando Programação Linear Inteira Mista. Esta tese é mais um exemplo desse paradigma de modelagem, sendo que a discussão anterior mostrou algumas de suas limitações na aplicação ao problema de projeto de redes logísticas. Além disso, a análise dos resultados inspiraram algumas outras idéias. Assim, pretende-se explorar no futuro os seguintes temas de pesquisa: não-linearidades na função objetivo; sazonalidade e inclusão de matérias-primas e manufatura (cadeia de suprimentos); e economias de escopo com operadores logísticos.

Não-linearidade. Deseja-se desenvolver pesquisas que envolvam aspectos nãolineares, como economias de escala nos centros de distribuição (suas capacidades agora cresceriam de forma contínua e não discreta, assim como seus custos fixos anuais) e custos de estoque, já comentados.

Outro aspecto não-linear interessante acontece quando se considera no mesmo modelo básico (vide item 3.3) os tamanhos de lote de entrega, que podem ser associados a diferentes tecnologias de transporte (caminhões menores e maiores, trens, etc). É interessante notar que a restrição de fluxo mínimo nos centros de distribuição do modelo clássico de Geoffrion e Graves (1974) advém da necessidade de ter um lote ferroviário mínimo de oito vagões. O custo de manutenção de estoques pode ser calculado como tamanho de lote $Q$ multiplicado por uma constante (Ballou, 1999, Cap. 10, p. 260-62). Usando-se os mesmos índices $i$ e $j$ do Capítulo 3 para denotar fábrica e $\mathrm{CD}$, dada a freqüência de entregas $f_{j}$ e o fluxo total $x_{i j}$ designado à instalação, o tamanho de lote é calculado como $Q=x_{i j} / f_{j}$. Como o fluxo $x_{i j}$ e a freqüência $f_{j}$ são variáveis de decisão, a função objetivo é não-linear (função racional). Essa característica foi explorada por Martos (2000), que usou um modelo de PLIM associado a uma heurística para fazer o projeto de localização de centros de distribuição de uma indústria petroquímica. Pretende-se abordar futuramente esse problema com Programação Não-Linear Inteira Mista. 
Sazonalidade e planejamento de materiais para manufatura. Pode-se estender a cadeia na direção dos insumos, incorporando-se restrições de mistura e processamento de materiais (MRP) com períodos múltiplos para tratar estoques e sazonalidades, como em Gutierrez (1996), Brown et al. (2001) e Kawamura; Ronconi; Yoshizaki (2002). Esses trabalhos, porém, usam Programação Linear clássica para um problema de nível tático, pois a rede logística já está definida. Desta forma, a idéia seria trabalhar esses problemas no nível estratégico, introduzindo como grau de liberdade a decisão de selecionar os sítios mais apropriados para produção e distribuição. Nesse sentido, há possibilidade de desdobrar uma fábrica, colocando-se, por exemplo, a finalização do produto mais a jusante na cadeia de suprimentos (princípio da postergação ou postponement), em substituição a um depósito tradicional (que não tem manufatura).

Economias de escopo com operadores logísticos. No item 5.2 discutiu-se a economia de escala obtida com a distribuição conjunta e o problema de como repartir esse ganho entre seus participantes. A questão aqui é diferente: uma rede logística real é complicada, com fluxos que se cruzam. Por exemplo, no cenário básico (sem sonegação), há centros de distribuição abertos em São Paulo, Goiânia e Joinville (vide Tabela 4.1). Como esses locais também contém fábricas (origens), seria possível sincronizar os veículos que fazem as transferências para trabalharem em uma rota fechada (ciclo) entre esses pontos. Ao se fazer isso, os custos de transporte de transferência seriam menores e, portanto, o operador logístico (que coordena esses fluxos) poderia conseguir fretes menores. Isto reduziria os fretes de transferência e. por conseguinte, aumentaria a possibilidade de abertura de depósitos. Isto, por sua vez, teria impacto positivo nos fretes de distribuição, pois haveria maior opções de depósitos para a entrega de produtos. Considerando que os fretes (transferência e distribuição) são os itens A da curva de custo logístico (ver Figura 4.20), o potencial de economia é grande. Este é um tema interessante que será melhor explorado. 


\subsection{Comentários finais}

Os objetivos estabelecidos no Capítulo 1 são:

- "Estudar os tradeoffs entre custos logísticos e o ICMS;

- "Avaliar a influência potencial do ICMS no projeto de sistemas de distribuição física;

- "Discutir o impacto geral da estrutura do ICMS na logística de empresas brasileiras."

Para atendê-los, concebeu-se um cenário idealizado mas plausível, o qual foi explorado através de um modelo matemático de Programação Linear Inteira Mista. Viu-se como o tributo afeta grandemente os custos logísticos e a decisão de instalar centros de distribuição, dada a indiferença ou não do canal de distribuição ao crédito do ICMS. Isto, na prática, significa saber se seus clientes são sonegadores potenciais e tomar a decisão de usar isto em benefício próprio. Assim, concluiu-se que é fundamental integrar o planejamento tributário à logística, sob pena da indústria perder competitividade. Portanto, considera-se que os objetivos acima foram cumpridos.

Como última citação, vale a pena recordar Rivett (1980, p. 145) referindo um trecho de Robert Louis Stevenson:

"Fazemos uma estranha imagem da nossa jornada aos nossos sonhos, marchando sem cessar, privando-nos de tempo para repousar (pioneiros infatigáveis e aventureiros). É verdade que nós nunca atingiremos a meta é ainda mais provável que não haja tal lugar. Breve, breve, parece, você deve conseguir chegar ao topo da montanha, mas, um pouco mais distante, contra o sol poente, surgem os telhados do El Dorado. Pouco você desconfia que, para sua benção, viajar esperançosamente é melhor do que chegar e que o verdadeiro sucesso é trabalhar."

Essa frase sintetiza muito bem o espírito do pesquisador e docente. A jornada continua. 


\section{ANEXO A - MESORREGIÕES PARA MERCADOS}

\begin{tabular}{|c|c|c|}
\hline ESTADO & Mesorregião & Índice \\
\hline $\mathrm{AL}$ & Agreste Alagoano/AL & K_1 \\
\hline $\mathrm{AL}$ & Leste Alagoano/AL & K_2 \\
\hline $\mathrm{AL}$ & Sertão Alagoano/AL & K_3 \\
\hline $\mathrm{AC}$ & Vale do Acre/AC & K_4 \\
\hline $\mathrm{AC}$ & Vale do Jurua/AC & K_5 \\
\hline AM & Centro Amazonense/AM & K_6 \\
\hline AM & Norte Amazonense/AM & K_7 \\
\hline $\mathrm{AM}$ & Sudoeste Amazonense/AM & K_8 \\
\hline $\mathrm{AM}$ & Sul Amazonense/AM & K_9 \\
\hline $\mathrm{AP}$ & Norte do Amapa/AP & K_10 \\
\hline $\mathrm{AP}$ & Sul do Amapa/AP & K_11 \\
\hline BA & Centro Norte Baiano/BA & K_12 \\
\hline BA & Centro Sul Baiano/BA & K_13 \\
\hline BA & Extremo Oeste Baiano/BA & K_14 \\
\hline BA & Metropolitana de Salvador/BA & K_15 \\
\hline BA & Nordeste Baiano/BA & K_16 \\
\hline BA & Sul Baiano/BA & K_17 \\
\hline BA & Vale São-Franciscano da Bahia/BA & K_18 \\
\hline $\mathrm{CE}$ & Centro-Sul Cearense/CE & K_19 \\
\hline $\mathrm{CE}$ & Jaguaribe/CE & K_20 \\
\hline $\mathrm{CE}$ & Metropolitana de Fortaleza/CE & K_21 \\
\hline $\mathrm{CE}$ & Noroeste Cearense/CE & K_22 \\
\hline $\mathrm{CE}$ & Norte Cearense/CE & K_23 \\
\hline $\mathrm{CE}$ & Sertões Cearenses/CE & K_24 \\
\hline $\mathrm{CE}$ & Sul Cearense/CE & K_25 \\
\hline DF & Distrito Federal/DF & K_26 \\
\hline ES & Central Espírito-santense/ES & K_27 \\
\hline ES & Litoral Norte Espírito-santense/ES & K_28 \\
\hline ES & Noroeste Espírito-santense/ES & K_29 \\
\hline ES & Sul Espírito-santense/ES & K_30 \\
\hline GO & Centro Goiano/GO & K_31 \\
\hline GO & Leste Goiano/GO & K_32 \\
\hline GO & Noroeste Goiano/GO & K_33 \\
\hline GO & Norte Goiano/GO & K_34 \\
\hline GO & Sul Goiano/GO & K_35 \\
\hline MA & Centro Maranhense/MA & K_36 \\
\hline MA & Leste Maranhense/MA & K_37 \\
\hline MA & Norte Maranhense/MA & K_38 \\
\hline MA & Oeste Maranhense/MA & K_39 \\
\hline MA & Sul Maranhense/MA & K_40 \\
\hline MT & Centro-Sul Mato-grossense/MT & K_41 \\
\hline MT & Nordeste Mato-grossense/MT & K_42 \\
\hline MT & Norte Mato-grossense/MT & K_43 \\
\hline MT & Sudeste Mato-grossense/MT & K_44 \\
\hline MT & Sudoeste Mato-grossense/MT & K_45 \\
\hline MS & Centro Norte de Mato Grosso do Sul/MS & K_46 \\
\hline MS & Leste de Mato Grosso do Sul/MS & K_47 \\
\hline MS & Pantanais Sul Mato-grossense/MS & K_48 \\
\hline
\end{tabular}




\begin{tabular}{|c|c|c|}
\hline MS & Sudoeste de Mato Grosso do Sul/MS & K_49 \\
\hline MG & Campo das Vertentes/MG & K_50 \\
\hline MG & Central Mineira/MG & K_51 \\
\hline MG & Jequitinhonha/MG & K_52 \\
\hline MG & Metropolitana de Belo Horizonte/MG & K_53 \\
\hline MG & Noroeste de Minas/MG & K_54 \\
\hline MG & Norte de Minas/MG & K_55 \\
\hline MG & Oeste de Minas/MG & K_56 \\
\hline MG & Sul/Sudoeste de Minas/MG & K_57 \\
\hline MG & Triângulo Mineiro/Alto Paranaíba/MG & K_58 \\
\hline MG & Vale do Mucuri/MG & K_59 \\
\hline MG & Vale do Rio Doce/MG & K_60 \\
\hline MG & Zona da Mata/MG & K_61 \\
\hline PA & Baixo Amazonas/PA & K_62 \\
\hline PA & Marajo/PA & K_63 \\
\hline PA & Metropolitana de Belém/PA & K_64 \\
\hline PA & Nordeste Paraense/PA & K_65 \\
\hline $\mathrm{PA}$ & Sudeste Paraense/PA & K_66 \\
\hline $\mathrm{PA}$ & Sudoeste Paraense/PA & K_67 \\
\hline PB & Agreste Paraibano/PB & K_68 \\
\hline $\mathrm{PB}$ & Borborema/PB & K_69 \\
\hline $\mathrm{PB}$ & Mata Paraibana/PB & K_70 \\
\hline PB & Sertão Paraibano/PB & K_71 \\
\hline PR & Centro Ocidental Paranaense/PR & K_72 \\
\hline PR & Centro Oriental Paranaense/PR & K_73 \\
\hline PR & Centro-Sul Paranaense/PR & K_74 \\
\hline PR & Metropolitana de Curitiba/PR & K_75 \\
\hline PR & Noroeste Paranaense/PR & K_76 \\
\hline PR & Norte Central Paranaense/PR & K_77 \\
\hline PR & Norte Pioneiro Paranaense/PR & K_78 \\
\hline PR & Oeste Paranaense/PR & K_79 \\
\hline PR & Sudeste Paranaense/PR & K_80 \\
\hline PR & Sudoeste Paranaense/PR & K_81 \\
\hline $\mathrm{PE}$ & Agreste Pernambucano/PE & K_82 \\
\hline $\mathrm{PE}$ & Mata Pernambucana/PE & K_83 \\
\hline $\mathrm{PE}$ & Metropolitana de Recife/PE & K_84 \\
\hline $\mathrm{PE}$ & São Francisco Pernambucano/PE & K_85 \\
\hline $\mathrm{PE}$ & Sertão Pernambucano/PE & K_86 \\
\hline PI & Centro-Norte Piauiense/PI & K_87 \\
\hline PI & Norte Piauiense/PI & K_88 \\
\hline PI & Sudeste Piauiense/PI & K_89 \\
\hline PI & Sudoeste Piauiense/PI & K_90 \\
\hline RJ & Baixadas/RJ & K_91 \\
\hline RJ & Centro Fluminense/RJ & K_92 \\
\hline RJ & Metropolitana do Rio de Janeiro/RJ & K_93 \\
\hline RJ & Noroeste Fluminense/RJ & K_94 \\
\hline RJ & Norte Fluminense/RJ & K_95 \\
\hline RJ & Sul Fluminense/RJ & K_96 \\
\hline $\mathrm{RN}$ & Agreste Potiguar/RN & K_97 \\
\hline RN & Central Potiguar/RN & K_98 \\
\hline $\mathrm{RN}$ & Leste Potiguar/RN & K_99 \\
\hline $\mathrm{RN}$ & Oeste Potiguar/RN & K_100 \\
\hline RR & Norte de Roraima/RR & K_101 \\
\hline RR & Sul de Roraima/RR & K_102 \\
\hline
\end{tabular}




\begin{tabular}{|c|c|c|} 
RS & Centro Ocidental Rio-grandense/RS & K_103 \\
\hline RS & Centro Oriental Rio-grandense/RS & K_104 \\
\hline RS & Metropolitana de Porto Alegre/RS & K_105 \\
\hline RS & Nordeste Rio-grandense/RS & K_106 \\
\hline RS & Noroeste Rio-grandense/RS & K_107 \\
\hline RS & Sudeste Rio-grandense/RS & K_108 \\
\hline RS & Sudoeste Rio-grandense/RS & K_109 \\
\hline RO & Leste Rondoniense/RO & K_110 \\
\hline RO & Madeira-Guaporé/RO & K_111 \\
\hline SC & Grande Florianópolis/SC & K_112 \\
\hline SC & Norte Catarinense/SC & K_113 \\
\hline SC & Oeste Catarinense/SC & K_114 \\
\hline SC & Serrana/SC & K_115 \\
\hline SC & Sul Catarinense/SC & K_116 \\
\hline SC & Vale do Itajaí/SC & K_117 \\
\hline SP & Araçatuba/SP & K_118 \\
\hline SP & Araraquara/SP & K_119 \\
\hline SP & Assis/SP & K_120 \\
\hline SP & Bauru/SP & K_121 \\
\hline SP & Campinas/SP & K_122 \\
\hline SP & Itapetininga/SP & K_123 \\
\hline SP & Litoral Sul Paulista/SP & K_124 \\
\hline SP & Macro Metropolitana Paulista/SP & K_125 \\
\hline SP & Marília/SP & K_126 \\
\hline SP & Metropolitana de São Paulo/SP & K_127 \\
\hline SP & Piracicaba/SP & K_128 \\
\hline SP & Presidente Prudente/SP & K_129 \\
\hline SP & Ribeirão Preto/SP & K_130 \\
\hline SP & São José do Rio Preto/SP & K_131 \\
\hline SP & Vale do Paraíba Paulista/SP & K_132 \\
\hline SE & Agreste Sergipano/SE & K_133 \\
\hline LE & Leste Sergipano/SE & K_134 \\
\hline SE & Sertão Sergipano/SE & K_135 \\
\hline TO & Ocidental do Tocantins/TO & K_136 \\
\hline TO & Oriental do Tocantins/TO & K_137 \\
\hline & & \\
\hline & & \\
\hline
\end{tabular}




\section{ANEXO B - TABELA DE ALÍQUOTAS DE ICMS}

Vide próxima página 


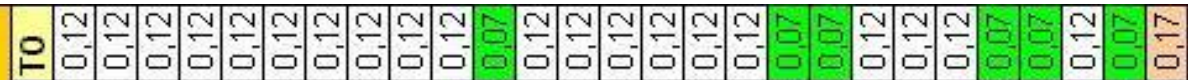

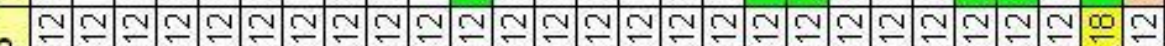

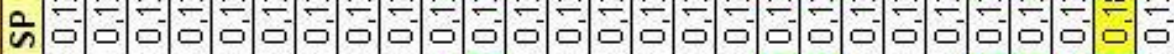

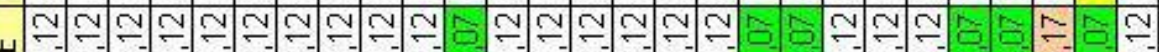

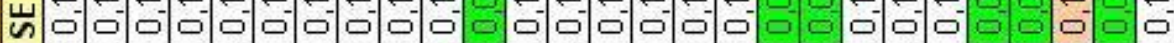

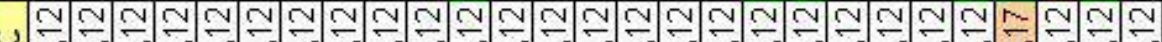

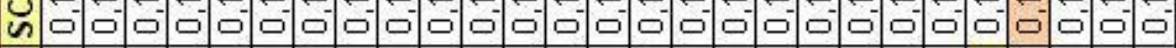

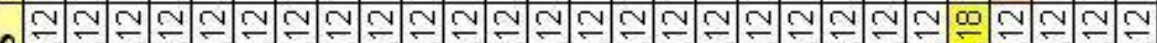

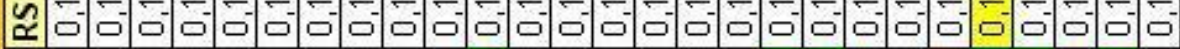

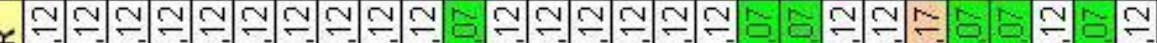

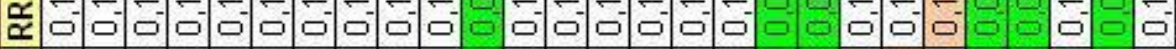

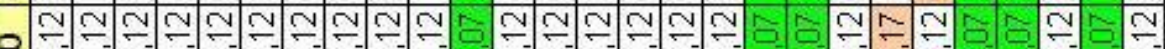

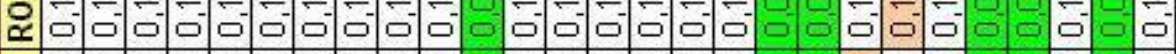

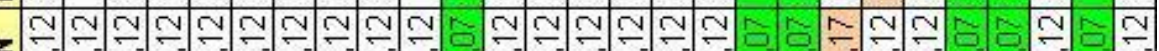

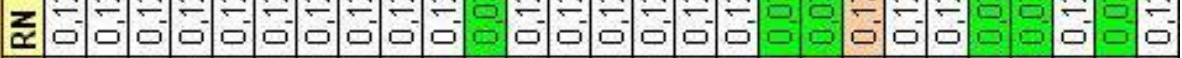

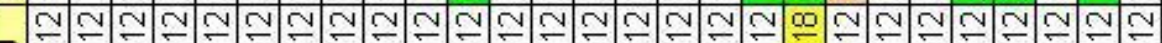

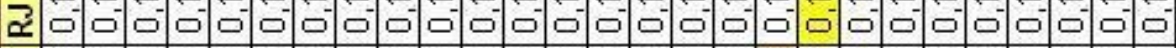

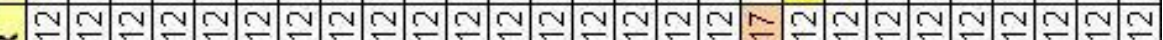

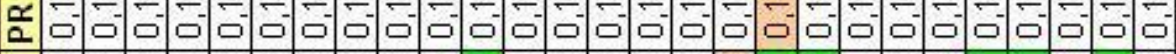

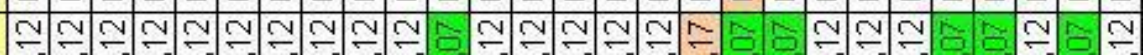

-

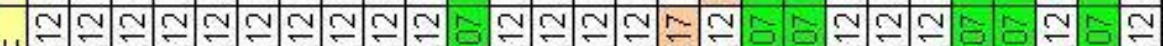

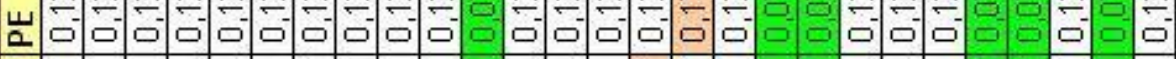

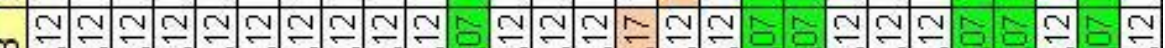

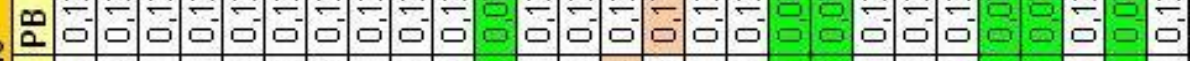

을

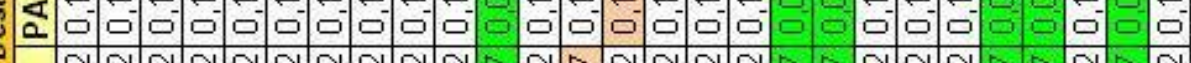

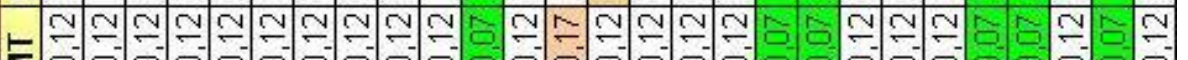

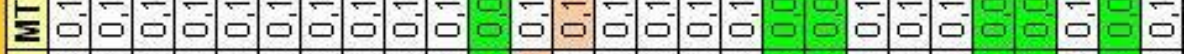

^

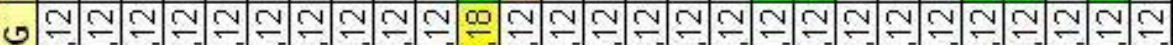

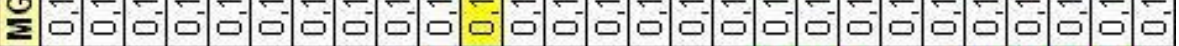

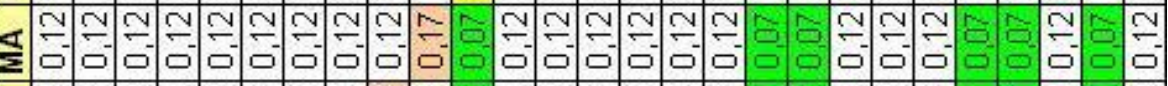

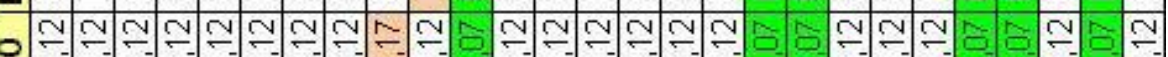

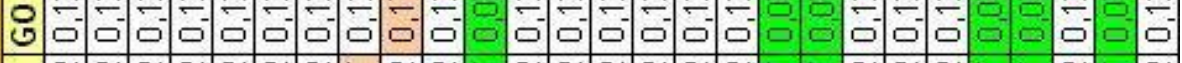

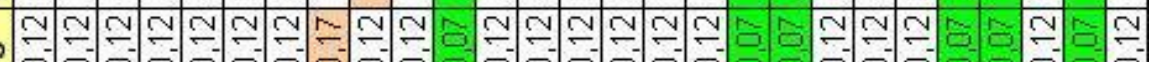

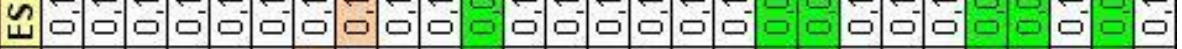

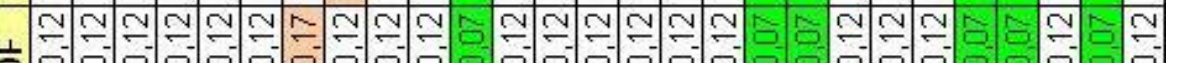

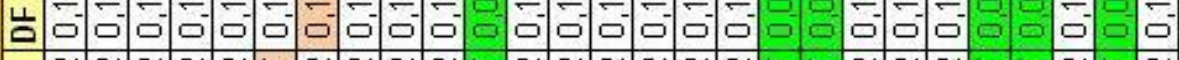

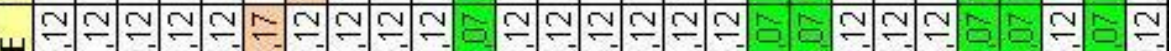

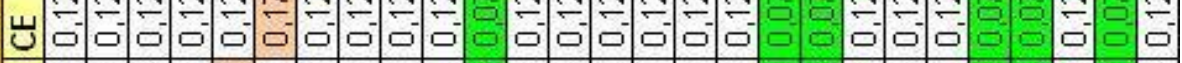

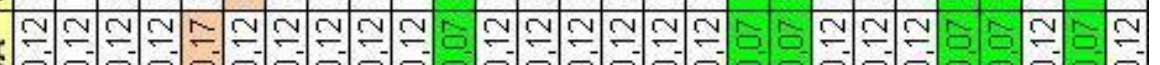

凹

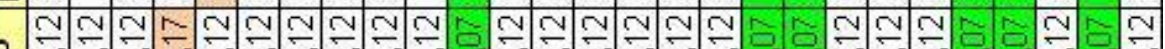

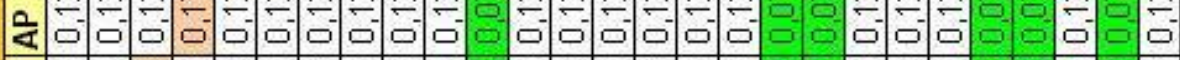

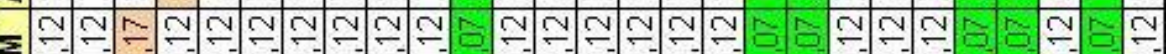

ミ

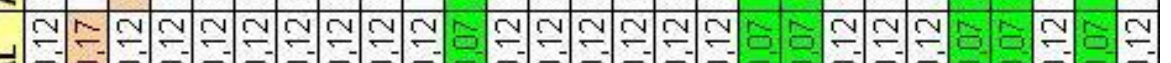

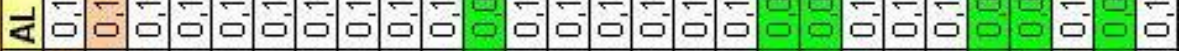

๖

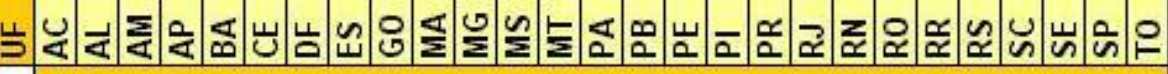
แลโฺ!ก

Tabela B.1. Porcentuais de incidência de ICMS sobre o produto entre Estados 


\section{ANEXO C - TABELAS DE CUSTO PARA DISTRIBUIÇÃO INDIVIDUAL}

As Tabelas C.1 a C.4. exibem os resultados para cada origem (fábrica), detalhando o custo logístico (transporte e instalações), o débito de ICMS e o custo total, colocando os cenários $0 \%$ e $100 \%$ de sonegação lado a lado.

\begin{tabular}{|c|c|c|c|c|}
\hline \multirow{2}{*}{$\begin{array}{l}\text { Fábrica } \\
\text { São Paulo/SP }\end{array}$} & \multirow{3}{*}{$\begin{array}{c}\text { (B) } \\
0 \% \text { sonegação } \\
(\mathbf{R} \$)\end{array}$} & \multirow{3}{*}{$\begin{array}{c}(\mathrm{C}) \\
100 \% \text { sonegação } \\
(\mathbf{R} \$)\end{array}$} & \multirow{2}{*}{\multicolumn{2}{|c|}{ Diferença (B-C) }} \\
\hline & & & & \\
\hline Itens de Custo & & & Absoluta $(\mathrm{R} \$)$ & Relativa \\
\hline Custo Fixo CD & $1.707 .180,00$ & $3.757 .188,53$ & $-2.050 .008,53$ & $-120,08 \%$ \\
\hline Frete Transferência & $4.107 .300,00$ & $3.901 .425,78$ & $205.874,22$ & $5,01 \%$ \\
\hline Frete Distribuição & $16.923 .463,65$ & $20.834 .907,88$ & $-3.911 .444,23$ & $-23,11 \%$ \\
\hline Custo var. CD. & $50.000,00$ & $130.510,53$ & $-80.510,53$ & $-161,02 \%$ \\
\hline Custo Logístico & $22.787 .943,65$ & $28.624 .032,72$ & $-5.836 .089,07$ & $-25,61 \%$ \\
\hline Débito de ICMS & $106.182 .113,75$ & $82.545 .145,00$ & $23.636 .968,75$ & $22,26 \%$ \\
\hline Custo Total & $128.970 .057,40$ & 111.169.177,72 & $17.800 .879,68$ & $13,80 \%$ \\
\hline
\end{tabular}

Tabela C.1. Custos dos Cenário Puros: Distribuição Independente Origem São Paulo

\begin{tabular}{|c|c|c|c|c|}
\hline \multirow{3}{*}{$\begin{array}{l}\text { Fábrica } \\
\text { Joinville/SC } \\
\text { Itens de Custo }\end{array}$} & (B) & (C) & \multirow{2}{*}{\multicolumn{2}{|c|}{ Diferença (B-C) }} \\
\hline & \multirow{2}{*}{$\begin{array}{c}\text { 0\% sonegação } \\
(\mathbf{R} \$)\end{array}$} & \multirow{2}{*}{$\begin{array}{c}100 \% \text { sonegação } \\
(\mathrm{R} \$)\end{array}$} & & \\
\hline & & & Absoluta $(\mathrm{R} \$)$ & Relativa \\
\hline Custo Fixo CD & $1.296 .330,68$ & $1.637 .766,68$ & $-341.436,00$ & $-26,3 \%$ \\
\hline Frete Transferência & $2.874 .800,00$ & $2.116 .118,94$ & $758.681,06$ & $26,4 \%$ \\
\hline Frete Distribuição & $9.735 .946,44$ & $11.047 .485,29$ & $-1.311 .538,85$ & $-13,5 \%$ \\
\hline Custo var. CD. & $40.000,00$ & $41.834,22$ & $-1.834,22$ & $-4,6 \%$ \\
\hline Custo Logístico & $13.947 .077,12$ & $14.843 .205,13$ & $-896.128,01$ & $-6,4 \%$ \\
\hline Débito de ICMS & $45.703 .453,75$ & $40.538 .130,75$ & $5.165 .323,00$ & $11,3 \%$ \\
\hline Custo Total & $59.650 .530,87$ & $55.381 .335,88$ & $4.269 .194,99$ & $7,2 \%$ \\
\hline
\end{tabular}

Tabela C.2. Custos dos Cenário Puros: Distribuição Independente Origem Joinville 


\begin{tabular}{|c|c|c|c|c|}
\hline \multirow{2}{*}{$\begin{array}{l}\text { Fábrica } \\
\text { Goiânia/GO }\end{array}$} & \multirow{3}{*}{$\begin{array}{c}\text { (B) } \\
\text { 0\% sonegação } \\
\text { (R\$) }\end{array}$} & \multirow{3}{*}{$\begin{array}{c}(\mathrm{C}) \\
100 \% \text { sonegação } \\
(\mathbf{R} \$)\end{array}$} & \multirow{2}{*}{\multicolumn{2}{|c|}{ Diferença (B-C) }} \\
\hline & & & & \\
\hline Itens de Custo & & & Absoluta $(\mathrm{R} \$)$ & Relativa \\
\hline Custo Fixo CD & $1.979 .202,68$ & $2.350 .294,00$ & $-371.091,32$ & $-18,7 \%$ \\
\hline Frete Transferência & $3.320 .965,86$ & $3.190 .598,78$ & $130.367,08$ & $3,9 \%$ \\
\hline Frete Distribuição & $4.916 .415,93$ & $5.935 .054,17$ & $-1.018 .638,24$ & $-20,7 \%$ \\
\hline Custo var. CD. & $57.652,11$ & $67.760,22$ & $-10.108,11$ & $-17,5 \%$ \\
\hline Custo Logístico & $10.274 .236,58$ & $11.543 .707,17$ & $-1.269 .470,59$ & $-12,4 \%$ \\
\hline Débito de ICMS & $35.324 .576,00$ & $26.884 .226,50$ & $8.440 .349,50$ & $23,9 \%$ \\
\hline Custo Total & $45.598 .812,58$ & $38.427 .933,67$ & $7.170 .878,91$ & $15,7 \%$ \\
\hline
\end{tabular}

Tabela C.3. Custos dos Cenário Puros: Distribuição Independente Origem Goiânia

\begin{tabular}{|c|c|c|c|c|}
\hline \multirow{2}{*}{$\begin{array}{l}\text { Fábrica } \\
\text { Recife/PE }\end{array}$} & \multirow{3}{*}{$\begin{array}{c}\text { (B) } \\
0 \% \text { sonegação } \\
(\mathrm{R} \$)\end{array}$} & \multirow{3}{*}{$\begin{array}{c}(\mathrm{C}) \\
100 \% \text { sonegação } \\
(\mathrm{R} \$)\end{array}$} & \multirow{2}{*}{\multicolumn{2}{|c|}{ Diferença (B-C) }} \\
\hline & & & & \\
\hline Itens de Custo & & & Absoluta (R\$) & Relativa \\
\hline Custo Fixo CD & $1.365 .744,00$ & $1.707 .180,00$ & $-341.436,00$ & $-25,0 \%$ \\
\hline Frete Transferência & $3.605 .056,64$ & $3.679 .180,98$ & $-74.124,34$ & $-2,1 \%$ \\
\hline Frete Distribuição & $2.302 .901,77$ & $2.470 .137,83$ & $-167.236,06$ & $-7,3 \%$ \\
\hline Custo var. CD. & $35.031,86$ & $36.702,56$ & $-1.670,70$ & $-4,8 \%$ \\
\hline Custo Logístico & $7.308 .734,27$ & $7.893 .201,37$ & $-584.467,10$ & $-8,0 \%$ \\
\hline Débito de ICMS & $14.808 .265,25$ & $11.941 .031,75$ & $2.867 .233,50$ & $19,4 \%$ \\
\hline Custo Total & $22.116 .999,52$ & $19.834 .233,12$ & $2.282 .766,40$ & $10,3 \%$ \\
\hline
\end{tabular}

Tabela C.4. Custos dos Cenários Puros: Distribuição Independente Origem Recife 


\section{ANEXO D - ARQUIVOS DE RESULTADOS}

O CD anexo contém todos os arquivos com resultados obtidos para os 47 cenários usados nesta tese, no formato de planilhas Excel 2000, além dos mapas associados em formato JPEG. Cada cenário tem duas planilhas de resultados e dois mapas diferentes.

Para identificar os cenários para análise, deve-se seguir o formato de codificação: AXX_Y.Y_sK, onde

- A: a série do processamento (os cenários atuais estão na série G).

- XX: número seqüencial do cenário (indica o preço médio).

- Y.Y: numeral denotando o índice de sonegação (por exemplo, 0.2 significa $20 \%$ de sonegação admitida na cadeia comercial).

- $\quad$ sK: onde $\mathrm{K}$ é um número; se $\mathrm{K}=1$, a planilha ou mapa se refere aos clientes indiferentes ao crédito de ICMS (sonegadores potenciais); se $K=2$, são clientes que querem o crédito de ICMS.

A planilha Arquivo_Mapa_de_Resultados contém estas e outras informações para auxiliar a procura pelos arquivos desejados (ver Figura D.1). Em particular, contém tabelas que permitem encontrar os códigos dos cenários.

Cada arquivo Excel contém doze planilhas do cenário para o tipo de cliente ( $\mathrm{s}=1$ ou 2, sonegador potencial ou não), identificados no nome do arquivo. As duas últimas planilhas podem ser desprezadas pois apenas servem para gerar os mapas em SPRING. As dez primeiras planilhas contém informações e resultados, a saber:

- ÍNDICES: códigos dos índices usados no modelo implementado em GAMS.

- RESUMO: uma consolidação de volumes movimentados e custos para cada origem possível.

- Sd_resuK: planilha auxiliar para obter o RESUMO; pode ser desprezada.

- Sd_dstdK: movimentação de cada CD para cada cliente atendido via depósito, por mercadoria ou origem. 
- Sd_dstfK: entrega direta da fábrica, identificando fábrica de origem, destino e volumes.

- Sd_trnK: volume transferido fábrica-CD.

- Sd_p0PK:quatro planilhas, uma para cada produto P, mostrando volume movimentado do produto $\mathrm{P}$ para qualquer par origem/mercado.

\begin{tabular}{|c|c|c|c|c|c|c|c|}
\hline & \multicolumn{6}{|c|}{ Diversos Produtos } \\
\hline & & \multicolumn{6}{|c|}{ Índice de Sonegação } \\
\hline & & 0,0 & 0,2 & 0,4 & 0,6 & 0,8 & 1,0 \\
\hline \multirow{11}{*}{ 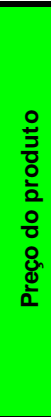 } & $\mathrm{R} \$ 12,50$ & & & & & & G052_1.0 \\
\hline & $\mathrm{R} \$ 62,50$ & & & & & & G051 1.0 \\
\hline & $\mathrm{R} \$ 125,00$ & & & & & & G05_1.0 \\
\hline & $\mathrm{R} \$ 625,00$ & G04_0.0 & G04_0.2 & G04_0.4 & G04_0.6 & G04_0.8 & G04_1.0 \\
\hline & $\mathrm{R} \$ 1.250,00$ & G02_0.0 & G02_0.2 & G02_0.4 & G02_0.6 & G02_0.8 & G02_1.0 \\
\hline & $\mathrm{R} \$ 1.875,00$ & & & & & & G053_1.0 \\
\hline & $R \$ 2.500,00$ & G01_0.0 & G01_0.2 & G01_0.4 & G01_0.6 & G01_0.8 & G01_1.0 \\
\hline & $\mathrm{R} \$ 3.125,00$ & & & & & & G054_1.0 \\
\hline & $R \$ 3.750,00$ & & & & & & G055_1.0 \\
\hline & $R \$ 4.375,00$ & & & & & & G056_1.0 \\
\hline & $\mathrm{R} \$ 5.000,00$ & G03_0.0 & G03_0.2 & G03_0.4 & G03_0.6 & G03_0.8 & G03_1.0 \\
\hline
\end{tabular}

\begin{tabular}{|c|c|c|c|c|c|}
\hline \multicolumn{7}{|c|}{ Diversos Produtos (Preço do Produto R\$2.500,00) } \\
\hline \multicolumn{7}{|c|}{ Índice de Sonegação } \\
\hline 0,0 & 0,025 & 0,05 & 0,1 & 0,15 & 0,2 \\
\hline G01_0.0 & G01_0.025 & G01_0.05 & G01_0.1 & G01_0.15 & G01_0.2 \\
\hline
\end{tabular}

\begin{tabular}{|c|c|c|c|c|c|c|}
\cline { 2 - 7 } \multicolumn{1}{c|}{} & \multicolumn{7}{c|}{ Unico Produto a $\mathbf{R} \mathbf{2 . 5 0 0 , 0 0}$} \\
\cline { 2 - 7 } \multicolumn{1}{c|}{} & \multicolumn{7}{c|}{ Índice de Sonegação } \\
\cline { 2 - 7 } & 0,0 & 0,2 & 0,4 & 0,6 & 0,8 & 1,0 \\
\hline Produto SP & G11_0.0_P1 & G11_0.2_P1 & G11_0.4_P1 & G11_0.6_P1 & G11_0.8_P1 & G11_1.0_P1 \\
\hline Produto SC & G11_0.0_P2 & & & & & G11_1.0_P2 \\
\hline Produto GO & G11_0.0_P3 & & & & & G11_1.0_P3 \\
\hline Produto PE & G11_0.0_P4 & & & & & G11_1.0_P4 \\
\hline
\end{tabular}

Figura D.1. Mapas de código dos cenários 


\section{ANEXO E - TABELA DE MUNICÍPIOS, MICRO E MESORREGIÕES IBGE}

O CD também contém a base de dados de municípios do IBGE para 1997, utilizada na confecção da tese. Essa base de dados contém todos os municípios brasileiros de então, e sua agregação bottom up em micro, mesorregiões e Estados da Federação. Além disso, contém a população e a localização (em latitude e longitude) desses municípios. 


\section{LISTA DE REFERÊNCIAS}

ACKOFF, R.L. Redesigning the future. New York: John Wiley \& Sons, 1974.

ACKOFF, R.L.; J. GHARAJEDAGHI. Reflections on systems and their models. Systems Research, V.13, n.1, pp. 13-23, 1996.

AMARAL, L.P. Modelo logístico de apoio à decisão de localização de centros de distribuição de uma indústria de produtos perecíveis. 1991. Trabalho de Formatura - Escola Politécnica, Universidade de São Paulo. São Paulo.

ASSOCIAÇÃO BRASILEIRA DE MOVIMENTAÇÃO E LOGÍSTICA - ABML. O Conceito de Operador Logístico. Publicado como suplemento da revista Tecnologística, fev. 1999.

ÁVILA, P.G.P. Estudo do processo de decisão da localização de pontos de distribuição e da competitividade logística de uma indústria de produtos de consumo de massa. 1996. 156p. Dissertação (Mestrado) - Faculdade de Economia, Administração e Contabilidade, Universidade de São Paulo. São Paulo.

BALLOU, R.H. DISPLAN: a multiproduct plant/warehouse location model with nonlinear inventory costs. Journal of Operations Management, V.5, no. 1, nov. 1984. p. $75-80$.

BALLOU, R.H. Logística Empresarial. São Paulo: Atlas, 1992.

BALlOU, R.H. Business Logistics Management: planning, organizing, and controlling the supply chain. 4. ed. Upper Saddle River: Prentice Hall, 1999.

BALLOU, R.H.; MASTERS, J.M. Commercial Software for Locating Warehouses and Other Facilities. Journal of Business Logistics, V.14, no. 2, 1993. p. 71-107.

BALLOU, R.H.; MASTERS, J.M. Facility Location Commercial Software Survey. Journal of Business Logistics, V.20, no. 1, 1999. p. 215-232.

BIXBY, R.E. Solving real world linear problems: a decade or more of progress. Operations Research. V.50, no. 1, jan.-fev. 2002. p. 3-15. 
BOWERSOX, D.J.; CLOSS, D.J. Logistical Management: the integrated supply chain process. New York: McGraw-Hill, 1996.

BRANDEAU, M.L.; S.S. CHIU. An overview of representative problems in location research. Management Science, V. 35, no. 7, pp. 645-74, 1989.

BRASIL. Assembléia Nacional Constituinte. Constituição da República Federativa do Brasil de 05/Out./1988. $3^{\text {a }}$. ed. São Paulo: Atlas, 1993.

BROOKE, A.; KENDRICK, D.; MEERAUS, A.; RAMAN, R. GAMS: A User's Guide. Washington: GAMS Development Corporation, 1998. Disponível em http://www.gams.com.

BROWN, G.G.; DELL, R.F.; WOOD, R.K. Optimization and persistence. Interfaces, V. 27, no. 5, set-out. 1997, p. 15-37.

BROWN, G.G.; KEEGAN, J.; VIGUS, B; WOOD, R.K. The Kellogg Company optimizes production, inventory, and distribution. Interfaces, V. 31, no. 6, nov.-dez. 2001, p. 1-15.

BUENO NETO, P.R. Pesquisa Operacional - Notas de Aula. São Paulo: Fundação Carlos Alberto Vanzolini, 1988.

CASSONE, V. Sistema Tributário Nacional. São Paulo: Atlas, 1995.

CHURCHMAN, C.W. Introdução à Teoria dos Sistemas. Petrópolis: Editora Vozes, 1971. $2^{\mathrm{a}}$. edição.

CONSELHO NACIONAL DE POLÍTICA FAZENDÁRIA (CONFAZ). Arrecadação do ICMS - Valores Correntes 2000. Brasília: Ministério da Fazenda, 2001 .

CORONADO, O. Contribuição para o estudo de formação de preços e planejamento de resultado com a logística integrada no setor atacadista/ distribuidor. 2000. 172p. Tese (Doutorado) - Faculdade de Economia, Administração e Contabilidade, Universidade de São Paulo. São Paulo.

ESTADO DE GOIÁS. Regulamento do Código Tributário do Estado de Goiás. Decreto $\mathrm{N}^{\circ}$ 4.852, de 19/Dez./1997, Anexos V e VIII. Disponível em www.goias.gov.br Acesso em junho de 2002. 
FLEURY, P.F.. Introdução. In: FLEURY, P.F.; WANKE, P.; FIGUEIREDO, K.F. (Org.). Logística Empresarial: a perspectiva brasileira. São Paulo: Atlas, 2000. p. $19-26$.

FUNDAÇÃO VANZOLINI. Planejamento de Rede Logística no Nordeste. São Paulo: Jul. 2000 (Relatório técnico).

GEOFFRION, A.M. Better distribution planning with computer models. Harvard Business Review V.54, no. 4, jul.-ago. 1976a, p. 92-99.

GEOFFRION, A.M. The purpose of mathematical programming is insight, not numbers. Interfaces V.7, no. 1, jan.-fev.. 1976b, p. 81-93.

GEOFFRION, A.M.; G.W. GRAVES. Multicommodity Distribution System Design by Benders Decomposition. Management Science V. 20, no. 5, pp. 822-844, 1974.

GEOFFRION, A.M.; POWERS, R.F. Twenty Years of Strategic Distribution System Design: An Evolutionary Perspective. Interfaces V. 25, no. 5, set.out. 1995, p. 105127.

GIANELLA, C.M.M. Modelo de apoio à decisão logística de localização de depósitos de produtos químicos. 1989. Trabalho de Formatura - Escola Politécnica, Universidade de São Paulo. São Paulo.

GODOY, G.K.; YOSHIZAKI, H.T.Y. Estudo comparativo de softwares de Programação Matemática para uso didático. In: ENCONTRO NACIONAL DE ENGENHARIA DE PRODUÇÃO - XV ENEGEP, 15. São Carlos, 1995. Anais. São Carlos: UFSCar, 1995.

GUTIERREZ, C.J. Development and Application of a Linear Programming Model to Optimize Production and Distribution of a Manufacturing Company. 1996. Dissertação (Mestrado) - Massachusetts Institute of Technology. Cambridge.

HAX, A.C.; CANDEA, D. Production and inventory management. Englewood Cliffs, Prentice-Hall, 1984.

HAYAKAWA, S.I.; HAYAKAWA, A.R. Language in thought and action. 5a. ed. San Diego: Harcourt Brace \& Company, 1990. 
HINO, C.M. Desenvolvimento de métodos para elaboração de modelos heurísticos de designação e seqüenciamento de planos de estivagem de navios porta-conteineres. Dissertação de Mestrado, Depto. de Engenharia Naval, EPUSP, 1999.

INSTITUTO BRASILEIRO DE GEOGRAFIA E ESTATÍSTICA (IBGE). Brasília, 2000. Apresenta diversas bases de dados acessíveis. Disponível em http://www.ibge.gov.br. Data de acesso: junho de 2000.

KAWAMURA, M.; RONCONI, D.P.; YOSHIZAKI, H.T.Y. Optimizing Transportation and Warehousing of Final Products in the Sugar and Ethanol Industry. São Paulo: Departamento de Engenharia de Produção, Escola Politécnica, Universidade de São Paulo, 2002. (working paper)

LAMBERT, D.M. Supply Chain Management. São Paulo: Vantine Consultoria, 22-23 Jun. 1998./Conferência proferida em São Paulo , 1998/

LATORRACA, N. Legislação Tributária. São Paulo: Atlas, 1975.

LOVE, R.F.; J.G. MORRIS; G.O. WESOLOWSKY. Facilities Location: models \& methods. New York: North-Holland, 1988.

MAGEE, J.F. Industrial Logistics. New York: McGraw-Hill, 1968.

MARCH, J.G.; SIMON, H.A. Organizations. New York: John Wiley \& Sons, 1958. MARTINS, I.G.S. Sistema Tributário na Constituição de 1988. São Paulo: Saraiva, 1989.

MARTOS, A. Projeto de Redes Logísticas com Consideração de Estoques e Modais: Aplicação de Programação Linear Inteira Mista à Indústria Petroquímica. Dissertação de Mestrado, Departamento de Engenharia de Produção, EPUSP, 2000.

MESAROVIC, M.D.; TAKAHARA, Y. General systems theory: mathematical foundations. New York: Academic Press, 1975.

NASCIMENTO, C.E.C. Malha Logística de uma Indústria de Sorvetes nas Regiões Norte e Nordeste. 2001. Trabalho de Formatura - Escola Politécnica, Universidade de São Paulo. São Paulo. 
NOVAES, A.G.N. Sistemas Logísticos: Transporte, Armazenagem e Distribuição de Mercadorias. São Paulo: Edgard Blücher, 1989.

NOVAES, A.G.N. Logística e Gerenciamento da Cadeia de Suprimentos. Rio de Janeiro: Campus, 2001.

NOVAES, A.G.N.; ALVARENGA, A.C. Logística Aplicada: Suprimento e Distribuição Física. 3. ed. São Paulo: Edgard Blücher, 2000.

RIBEIRO, N.V. Contribuição ao aperfeiçoamento de sistemas logísticos de distribuição no contexto tributário brasileiro: estudo de caso em indústria de bens de consumo. 1999. 172p. Dissertação (Mestrado) - Faculdade de Economia, Administração e Contabilidade, Universidade de São Paulo. São Paulo.

RIVETT, P. Model building for decision analysis. Chichester, UK: John Wiley \& Sons, 1980.

ROSA, D.D. Crédito de ICMS - Ilegitimidade Legislativa dos Estados. São Paulo: Legis Center, 2000. Disponível em http://www.legiscenter.com.br

ROSENTHAL, Richard E. GAMS Tutorial. 1992. Disponível em http://www.gams.com/docs/document.htm . Acesso em 18 de ago. de 2001.

SANTORO, M.C. Planejamento, Programação e Controle da Produção. São Paulo: Departamento de Engenharia de Produção, Escola Politécnica da USP. Apostila, 1991.

SECRETARIA DA RECEITA FEDERAL. Carga Tributária no Brasil 2000. Brasília: Ministério da Fazenda, 2002. Disponível em: www.receita.fazenda.gov.br/Arrecadacao/Carga_Fiscal/2000. Acesso em: 27 de jun. 2002.

SHAPIRO, J.F. Bottom-up vs. Top-down Approaches to Supply Chain Modeling. In: TAYUR, S.; GANESHAN, R.; MAGAZINE, M. (eds.). Quantitative Models for Supply Chain Management. Boston: Kluwer Academic, 1999. Cap. 23.

SHAPIRO, J.F. Modeling the Supply Chain. Pacific Grove: Duxbury, 2001.

SHIBA, S.; GRAHAM, A.; WALDEN, D. A new American TQM. Portland: Productivity Press, 1993. 
SIMCHI-LEVI, D.; KAMINSKY, P.; SIMCHI-LEVI, E. Designing and Managing the Supply Chain. Boston: McGraw-Hill, 2000.

SOUZA, R.G. Compêndio de Legislação Tributária. São Paulo: Editora Resenha Tributária, 1975.

THOMPSON, J.D. Organizations in action. New York: McGraw-Hill, 1967.

WINSTON, W. Introduction to Mathematical Programming. 2a. edição. New York: Duxbury Press, 1995.

YOSHIZAKI, H.T.Y. Planejamento e projeto de bases de modelos quantitativos de auxílio à decisão. Tese de Doutorado. Escola Politécnica da USP. São Paulo, Capítulo 7, 1997.

YOSHIZAKI, H.T.Y.; A.R.N. MUSCAT; J.L. BIAZZI. Decentralizing ethanol distribution in South eastern Brazil. Interfaces, V.26, n.6. Novembro-dezembro 1996.

YOSHIZAKI, H.T.Y.; A.R.N. MUSCAT; J.L. BIAZZI. Revisando a logística de distribuição de álcool etílico. Gestão\&Produção, V.4, n.2, pp. 174-185, agosto 1997.

ZENNARO, L.P. Modelo logístico de apoio à decisão de localização de depósitos de uma indústria alimentícia. 1993. Trabalho de Formatura - Escola Politécnica, Universidade de São Paulo. São Paulo. 